\title{
GEOLOGY OF THE BELVIDERE MOUNTAIN COMPLEX, \\ EDEN AND LOWELL, VERMONT
}

by

Marjorie Hollis Gale

\author{
U.S. Geological Survey \\ Open-file Report 80- 978
}

This report was originally submitted in partial fulfillment of the requirements for the Degree of Master of Science from the University of Vermont, March 1980.

This report is preliminary and has not been edited or reviewed for conformity with Geological Survey standards or nomenclature. Use of trade names is for descriptive purposes only and does not constitute endorsement by the U.S. Geological Survey. 
TABLE OF CONTENTS

Page

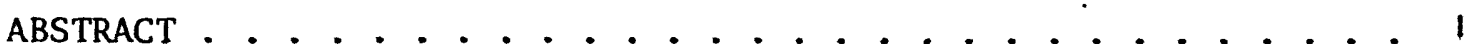
1

Chapter

1. INTRODUCTION .................... $1 a$

Statement of Problem and Purpose . . . . . . . . . 1

Location and Access ............... . 3

Topography and Drainage ............. 3

Geologic Setting ................. 5

Previous Works . . . . . . . . . . . . . . 7

Methods of Analysis .............. 10

Acknowledgments .. . . . . . . . . . . 11

2. STRATIGRAPHY .................. 12

Introduction ................... 12

Hazens Notch Formation.............. 16

Fine grained gneiss (wgn) . . . . . . . . . . . 17

Rusty schist (rs) .................. 17

Albite gneiss (agn) ................ . 21

Sericite schist (ss) . . . . . . . . . . 22

Belvidere Mountain Complex ............. 22

Muscovite schist (mus) . . . . . . . . . . . 23

Greenstone (bgs) . . . . . . . . . . . . . 25

Fine grained amphibolite (baf) . . . . . . . . 27

Coarse grained amphibolite (bac) . . . . . . . . 30

Ultramafic rocks (oud, outc) . . . . . . . . . 31

Ottauquechee Formation .............. . 32

Green phyllite (grp) . . . . . . . . . . . 32

Gray phyllite (gp) . . . . . . . . . . . . . 33

Black, carbonaceous phyllite (bcp) . . . . . . . 33

Phyllitic graywacke (pgw) . . . . . . . . . . . 34

Rusty and black schist (rbs) . . . . . . . . . . 34

Stowe Formation . . . . . . . . .. . . . . 35

Green and tan schists and phyllites (ucs) . . . . 35

Metaigneous dikes . . . . . . . . . . . . 36

Summary and Discussion . . . . . . . . . . . 36 
3. STRUCTURAL GEOLOGY ... . . . . . . . . . . . . 38

Introduction . . . . . . . . . . . . . . . . 38

Minor Folds and Foliations in Subareas 1 and 2 . . . . 39

$\mathrm{F} 1$ and $\mathrm{S} 1$. . . . . . . . . . . . . . 39

F2 and S2................... 42

$\mathrm{F} 3$ and $S 3$. . . . . . . . . . . . . . . . 45

F4 ...................... . 51

Major Folds in Subareas 1 and 2............ 51

Faults in Subareas 1 and 2 ............. 53

Locations 1-6, Figure 17 . . . . . . . . . . . 55

Locations 7-14, greenstone-muscovite schist contact (Fig. 17) ................ 57

Summary and Discussion of Subareas 1 and 2..... . 63

Minor Structures in Subarea 3 . . . . . . . . . 65

Primary structures .............. 65

Minor folds and foliations.......... 66

Correlation with Subareas 1 and 2 . . . . . . . 66

Major Structures in Subarea 3 . . . . . . . . 70

Summary and Discussion . . . . . . . . . . . 70

Structural Correlation with Previous Works . . . . 75

4. CHEMISTRY OF THE MAFIC ROCKS . . . . . . . . . . 77

5. PETROGRAPHY AND METAMORPHISM OF THE MAFIC ROCKS...$\quad$. 87

Introduction . . . . . . . . . . . . . . 87

Greenstone, bgs . . . . . . . . . . . . . . 88

Chlorite..................... 88

Epidote group .. . . . . . . . . . . . . 90

Amphibole ..................... 93

Albite..................... 96

Calcite ................... . 99

Quartz...................... 101

Biotite .................... 101

Sphene ....................... 101

Opaques . . . . . . . . . . . . . . . 102

Summary . . . . . . . . . . . . . . . 102

Fine Grained Amphibolite, baf . . . . . . . . . 107

Amphibole . . . . . . . . . . . . . 107

Albite . . . . . . . . . . . . . . . . 109

Epidote . . . . . . . . . . . . . . . . 109

Chlorite . . . . . . . . . . . . . . 111

Garnet . . . . . . . . . . . . . . . . 111

Calcite . . . . . . . . . . . . . . . 111

Sphene . . . . . . . . . . . . . . . 112

Biotite .................... 112

Quartz..................... 112

Opaques ...................... 112

Fine grained amphibolite--summary . . . . . . . 112 
Coarse Grained Amphibolite, bac. . . . . . . . . 117

Amphibole ................... 117

Epidote . . . . . . . . . . . . . . 118

Albite . . . . . . . . . . . . . . . . 118

Chlorite.................... 120

Garnet . . . . . . . . . . . . . . 120

Quartz...................... 120

Biotite . . . . . . . . . . . . . . 122

Sphene . . . . . . . . . . . . . . . . 122

Opaques ..................... 122

Coarse grained amphibolite--summary . . . . . . . 122

Metasedimentary Rocks . . . . . . . . . . . . 123

Summary and Discussion of Metamorphism . . . . . . 125

6. SUMMARY . . . . . . . . . . . . . . . 129

REFERENCES CITED . . . . . . . . . . . . . . . . . . . 132

.APPENDIXES

1. LOCATION AND DESCRIPTION OF ANALYZED SAMPLES . . . . . . 136

2. CHEMICAL DATA AND HISTOGRAMS . . . . . . . . . . . 146 


\section{LIST OF TABLES}

Table

Page

1. Modal Mineralogy Based on 1000 Points per Thin Section . . 18

2. Average Chemical Analyses . . . . . . . . . . 78

3. Estimated Modal Analyses for the Greenstone . . . . . . 89

4. Modal Mineralogy of the Amphibolites . . . . . . . 108 


\section{LIST OF FIGURES}

Figure

Page

1. Location of the Belvidere Mountain area . . . . . . . 4

2. Geologic setting ................. . 6

3. Stratigraphic correlation chart of previous works . . . 15

4. Contact of the rusty schist ( $r s$ ) and the greenstone (bgs) just south of location 221 on Plate II . . . . . . 20

5. Block of greenstone (bgs) in the muscovite schist . . . 24

6. Chlorite-actinolite pod in the fine grained amphibolite . 29

7. Sketch of cleavage relationships in some of the rocks of the Belvidere Mountain area .. . . . . . . . 40

8. Lower hemisphere equal-area projection of 22 poles to the S1 foliation in subarea 1........... 41

9. Lower hemisphere equal-area projection of 23 poles to the S1 foliation in subarea 2 . . . . . . . . . 43

10. F2 isoclinal fold of $\mathrm{S} 1$ compositional bands in the greenstone . . . . . . . . . . . . . . . .

11. Lower hemisphere equal-area projection of 166 poles to the S2 foliation in subarea $2 . .$. . . . . . .

12. Lower hemisphere equal-area projection of 102 poles to the $\mathrm{S} 2$ foliation in subarea $1 . . . . . . . .$.

13. Lower hemisphere equal-area projection of $38 \mathrm{~S} 1-\mathrm{S} 2$ intersection lineations and $\mathrm{F} 2$ fold axes . . . . . .

14. Lower hemisphere equal-area projection of 38 poles to the $\mathrm{S} 3$ foliation in subarea $1 . . . . . . . .$.

15. Lower hemisphere equal-area projection of 55 poles to the S3 foliation in subarea 2 . . . . . . . . . 50

16. Lower hemisphere equal-area projection of $66 \mathrm{~S} 2-\mathrm{S} 3$ intersection 1ineations and F3 fold axes . . . . . . 52

17. The summit area of Belvidere Mountain at a scale of $1: 10000$................... 
34. Chlorite pseudomorph of garnet in albite porphyroblast in bgs-106............ . 91

35. Pre-S2 epidote porphyroclast in bgs-208 . . . . . . . 92

36. Pre-S2 epidote aggregate in bgs-190. . . . . . . . . 92

37a. F2 isoclinal fold of compositional bands (S1)

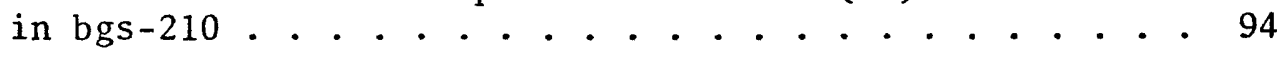

37b. Actinolite-chlorite rich band (Fig. 37a) parallel S1 with minerals aligned parallel to the F2 axial surface, and deformed by F3/S3 in bgs-210 . . . . . . 94

37c. Epidote aligned paralle1 to $\mathrm{S} 2$ within calcite-albitequartz-epidote band (parallel S1) in bgs-210 ..... 95

38. Pre-S2 amphibole porphyroclast in bgs-314 . . . . . . . 97

39. Albite and calcite intergrown in bgs-190 . . . . . . 97

40. Twinned albite porphyroclast (pre-S1 ?) in albitequartz band (S1) in bgs-125 ........... 98

41. Helicitic texture (S1) in albite porphyroblast (syn-S2) in bgs-106................. 100

42. Inclusions in albite porphyroblast continuous with matrix grains (S2) in bgs-329 ......... . 100

43. Mineral growth and deformation .......... . 103

44. ACF diagram for the greenstone $(\cdot)$ and amphibolites (+) 105

45. $\mathrm{Na}_{2} \mathrm{O}-\mathrm{AF}_{2} \mathrm{O}_{3}\left(\mathrm{Al}_{2} \mathrm{O}_{3}+\mathrm{Fe}_{2} \mathrm{O}_{3}\right)-\mathrm{CaO}-\mathrm{FMO}(\mathrm{FeO}+\mathrm{MgO}+\mathrm{MnO})$ tetrahedron for the biotite-albite zone of the medium pressure type (from Laird, 1977, p. 428) . . . . . 106

46. Sheared hornblende parallel S1 cross-cut by actinolite and epidote paralle1 S2 in baf-257 . . . . . . . . 110

47. Pre-S2 garnet porphyroblast in baf-308 . . . . . . . 110

48. Mineral growth and deformation of the amphibolites . . . 113

49. ACF diagram for the amphibolites . . . . . . . . . . 115 
50. $\mathrm{Na}_{2} \mathrm{O}$ versus $\mathrm{AF}_{2} \mathrm{O}_{3}$ versus $\mathrm{CaO}, \mathrm{AF}_{2} \mathrm{O}_{3}$ versus $\mathrm{CaO}$ versus FMO, and $\mathrm{Na}_{2} \mathrm{O}$ versus $\mathrm{AF}_{2} \mathrm{O}_{3}$ versus FMO triangular diagrams for the medium to high pressure, biotitealbite zone mafic rock phase assemblages (Laird, 1977, p. 440) .................. 116

51. Large S1/F1 hornblende, sheared and altered to a fibrous aggregate of chlorite, biotite, and amphibole parallel to S2 . . . . . . . . . 119

52. Kinked albite porphyroclast in bac-309 . . . . . . 121 


\section{LIST OF PLATES}

\section{Plate}

I. GEOLOGY OF THE BELVIDERE MOUNTAIN AREA, EDEN

$$
\text { AND LOWELL, VERMONT . . . . . . . . . . . Oversize }
$$

II. INDEX MAP . . . . . . . . . . . . . . . . "

III. F1 STRUCTURE MAP . . . . . . . . . . . . . . "

IV. F2 STRUCTURE MAP . . . . . . . . . . . . . " "

V. F3 STRUCTURE MAP ................ . . . is 
B. Mar jorie Hollis Gale*

ABSTRACT

The Belvidere Mountain area is located within the serpentine belt in the towns of Eden and Lowel1, Vermont. The Belvidere Mountain Complex, comprised of serpentinite, coarse grained amphibolite, fine grained amphibolite, greenstone, and muscovite schist, has been previously mapped as part of a stratigraphic sequence which youngs from west to east based on the structural control of the Green Mountain Anticlinorium. However, detailed mapping exposes a tectonic stratigraphy characterized by fault contacts between four structural packages which do coincide with previously mapped formations: Hazens Notch Fm.; Belvidere Mountain Complex; Ottauquechee Fm.; Stowe Fm. Additional faults exist within these packages.

Four fold events are recognized in the area. F2, F3, and F4 post-date the faults. F1 exhibits variable age relationships to the faults, and thus D1 represents a history of both fault and fold (F1) deformation associated with the emplacement of the Belvidere Mountain Complex.

Major and trace element chemistry support an ocean floor tholeitic basalt or gabbro protolith for the amphibolites and greenstone of the Belvidere Mountain Complex.

Based on field relationships and petrographic analyses of the Belvidere Mountain Complex and the surrounding metasedimentary rocks, the garnet and hornblende isograds (Doll et a1., 1961; Cady et a1., 1963) at Belvidere Mountain are not substantiated. Two metamorphic events are recognized in the metasedimentary rocks while at least three metamorphic events are recognized in the rocks of the Belvidere Mountain Complex. The variation in the metamorphic grade (epidoteamphibolite facies to greenschist facies) is confined to the Belvidere Mountain Complex, and follows the fault contacts of the amphibolites and greenstone. The textural and mineralogical gradational sequence of coarse grained amphibolite, fine grained amphibolite, and greenstone documents the early deformational and metamorphic history of cataclasis and retrograde metamorphism associated with transport onto the continental margin of mafic metaigneous rocks incorporated at the base of the serpentinite (mantle). These early events may well have occurred during imbrication of ocean crust and westward transport of ophiolites onto the continental margin. Greenschist facies metamorphism is also associated with the F2 folds. No change in the metamorphic assemblages is associated with F3 and F4.

*Present address: University of Vermont, Department of Geology, Burlington, Vermont 05401 
Chapter 1

\section{INTRODUCTION}

Statement of the Problem and Purpose

The purpose of this study is to determine the geology and origin of the Belvidere Mountain Formation (Chidester et al., 1978) in northern Vermont. This formation is presently regarded as part of a stratigraphic succession which youngs from west to east based on the control of the Green Mountain Anticlinorium (Cady et a1., 1963; Do11 et al., 1961; Chidester et al., 1978). However, the close association of the Belvidere Mountain Formation with the asbestos-bearing serpentinite body, its complex and variable metamorphic mineral assemblages (greenschist to coarse grained garnet-amphibolite), and the presence of similar rock types underlying obducted slabs of ancient ocean crust (ophiolite) warrant the field and laboratory analyses undertaken in this study.

The occurrence of garnet-amphibolite underlying faulted basal peridotite has been documented in Quebec (Laurent, 1975; 1977), Newfoundland (Williams and Smith, 1973; Malpas, 1976), Papua, New Guinea (Davies, 1971), and New Zealand (Coombs et al., 1976). In addition, the problems related to metamorphism of amphibolites associated with ophiolites are discussed by Malpas, Stevens, and Strong (1973), Graham and England (1976), and Woodcock and Robertson (1977). The most recent summary and discussion of the amphibolite-ophiolite association is by Coleman (1978) who discusses and summarizes four

$$
\text { In }(p 2 \text { q picows) }
$$


possible origins for the amphibolite: dynamothermal metamorphism of volcanic rocks and/or sediments at the base of the ophiolite during emplacement; metamorphism and imbrication of the gabbro of the ophiolite at the base of the peridotite; ocean floor metamorphism with subsequent transport; and the incorporation, at the base of the ophiolite, of slivers from a regionally developed amphibolite terrain. Williams and Smith (1973) interpreted the amphibolites and greenstones as resulting from contact dynamo-thermal metamorphism of mafic volcanic rocks during the early stages of ophiolite obduction. In this interpretation, the thermal metamorphism is explained by either frictional heat at the base of the thrust sheet, or the less likely retention of heat in the transported ophiolite at supracrustal levels (Williams and Smith, 1973). Laurent (1977) suggests that the discontinuous amphibolite lenses in Quebec are a metaigneous member of the ophiolite underplated beneath the basal peridotite at Thetford Mines. He suggests that the amphibolite formed during fragmentation of ocean lithosphere prior to ophiolite emplacement, and that retrograde metamorphism and deformation of these "aureole" rocks occurs both during and after thrust emplacement with the ophiolite onto the continental margin. In the Belvidere Mountain area, Cady et al. (1963) suggest that the protolith for the amphibolite and greenstone is water-laid mafic volcanic detritus. They conclude that regional metamorphism in the garnet zone at Belvidere Mountain reflects a more widespread garnet zone metamorphism, near the axis of the Green Mountain Anticlinorium, which has been subsequently completely altered during retrograde metamorphism. 
In view of these works, the relationship of the Belvidere Mountain Formation to the associated serpentinite is questioned. The significance of investigating and documenting the geology of the Belvidere Mountain Formation is twofold: to provide data necessary to interpret the origin of ultramafic and related rocks in northern Vermont; and to provide information applicable to understanding the common amphibolite-ultramafic association.

\section{Location and Access}

The study area is located in northern Vermont in towns of Eden, Eden Mil1s, and Lowell (Fig. 1). Asbestos is presently being mined at Belvidere Mountain. The area is represented by the Jay Peak and Hyde Park U. S. G. S. 15-minute quadrangles.

The eastern border of the study area is defined by the western slopes of Hadley Mountain and The Knob. Route 118 north from Eden to the old quarry road defines the western border of the area. The summit of Belvidere Mountain, and the town of Eden are the respective northern and southern boundaries. The total area studied is approximately 12 square miles.

Topography and Drainage

The area is characterized by a series of northeast trending ridges and valleys. The most conspicuous features, Belvidere Mountain and Hadley Mountain, are separated by a branch of the Missisquoi River. Topographic relief in the area is approximately 823 meters $(2,700$ feet $)$.

The northern slopes of Belvidere Mountain drain north to the Missisquoi River, into Canada, then southwest to Lake Champlain. The 


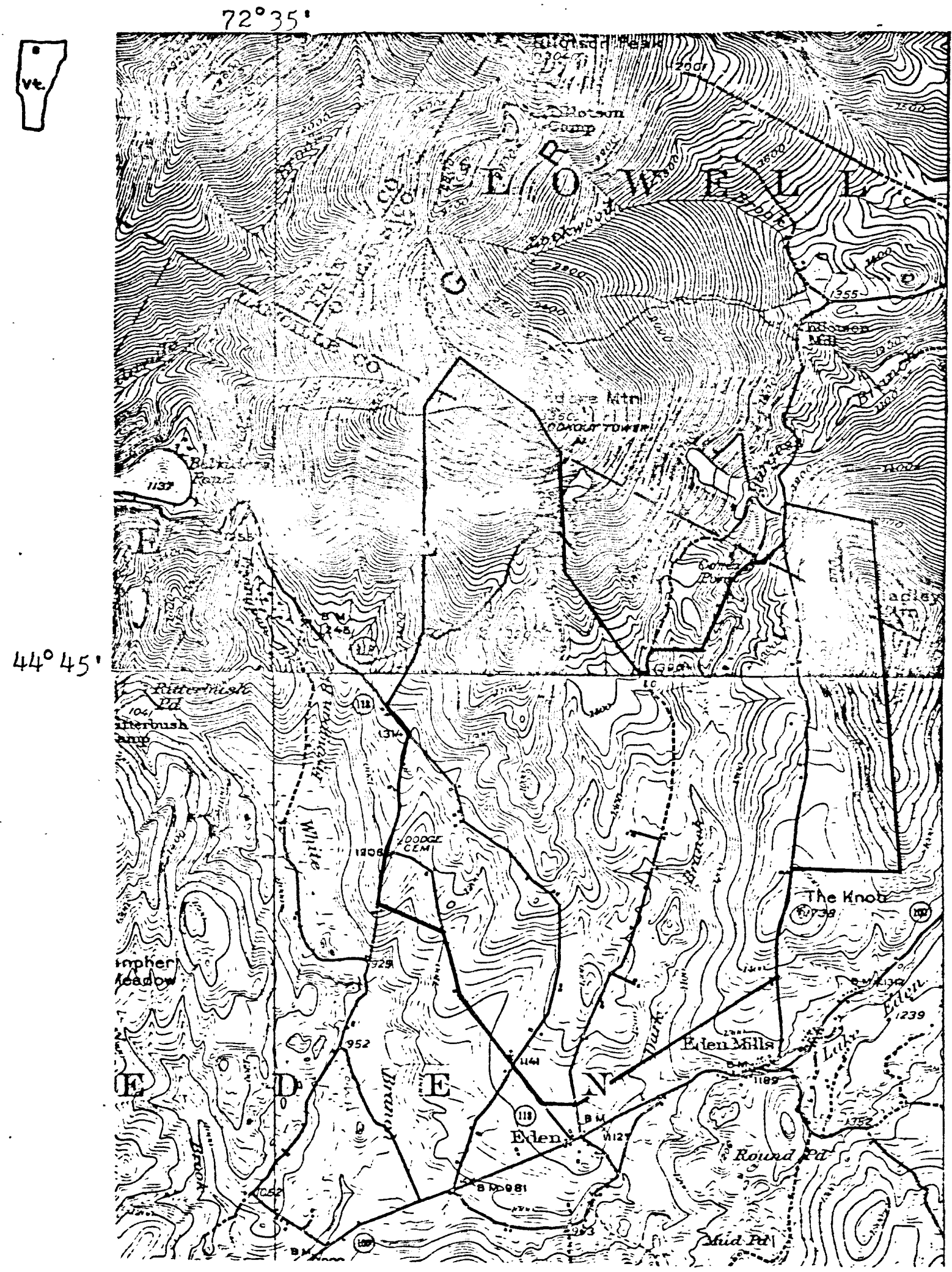

Figure 1. Location of the Belvidere Mountain area. Solid line describes the area mapped in this study. Scale: 1:62500. 
southern slopes of Belvidere Mountain drain south to Lake Eden and the Lamoille River.

\section{Geologic Setting}

The study area is located within the ultramafic belt which extends from southern Vermont north into Quebec for $250 \mathrm{~km}$ along the east limb of the Green Mountain-Sutton Mountain Anticlinorium. The area is within the internal domain of St. Julien and Hubert (1975). St. Julien and Hubert (1975) defined three northeast trending zones in the Quebec Appalachians. These zones (autochthonous domain, external domain, internal domain) are depicted on Fig. 2. The autochthonous domain is comprised of the Grenville basement and Paleozoic sediments of the St. Lawrence Lowland. The external domain, marked by thrust-imbricate structures and by the Quebec and Taconic Allochthons, consists predominant1y of Cambrian and Ordovician sandstones, shales, carbonates and flysch. The internal domain is represented by deformed and metamorphosed Cambrian clastic and volcanic rocks built upon the ancient continental margin, thrust-emplaced ophiolite complexes, an overlying breccia (St. Daniel Formation), and calc-alkalic volcanics (Ascot-Weedon Formation).

Within the internal domain, the geology of the Belvidere Mountain area at Eden Mi11s, Vermont represents an imbricate fault zone in which a variety of lithic packages are juxtaposed. Four fold generations are recognized in the area. The three most recent fold events post-date the faults. The relationship of faults to the early fold event is less clear. This study suggests that the faults and early folding are part of a long history of transport and em- 


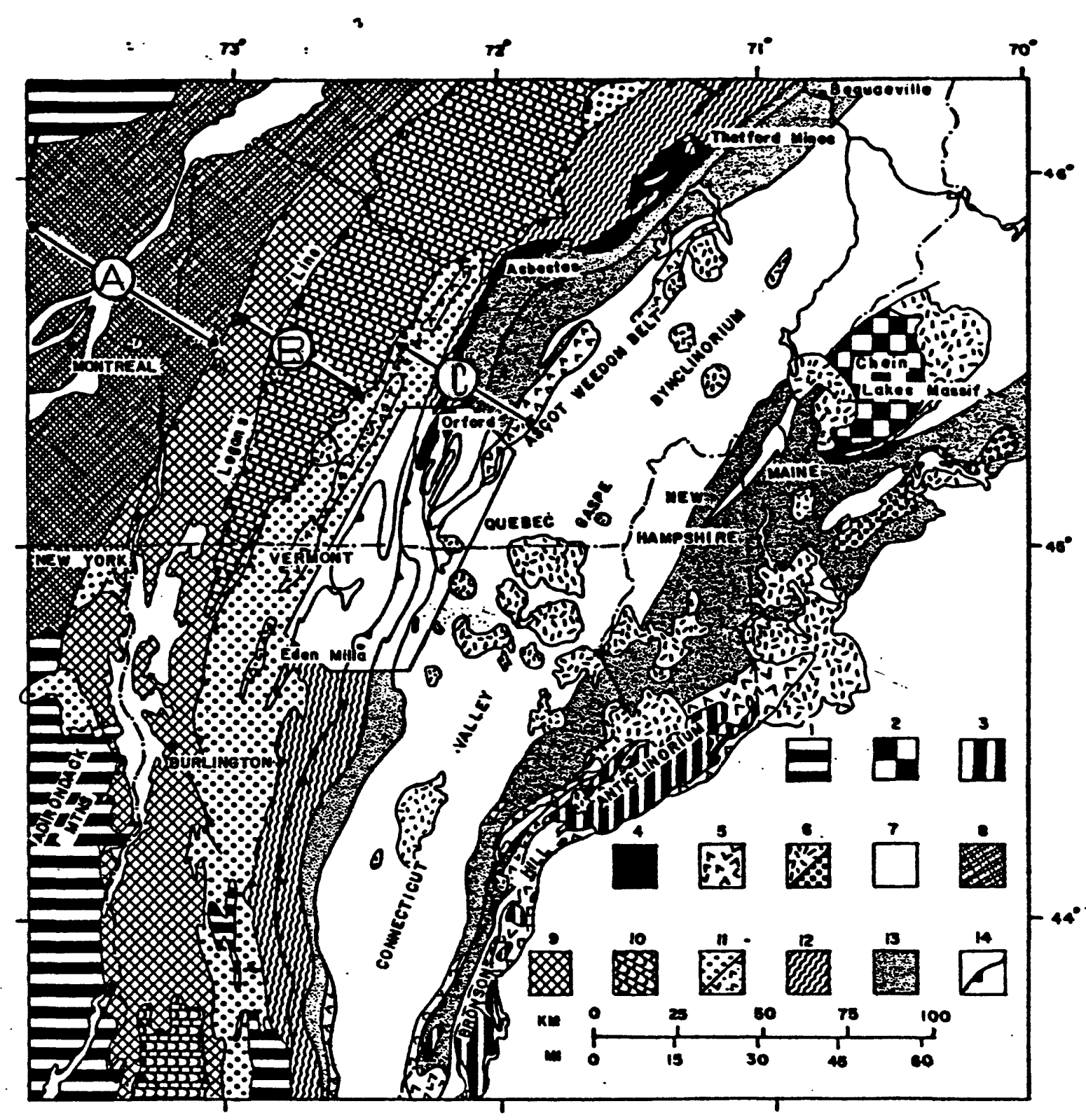

Figure 2. Geologic setting. Legend: (1) Grenville basement (1.0. b.y.); (2) Chain Lakes Massif (1.6 b.y.); (3) 0liverian basement (Ordovician? to Late Precambrian); (4) Ophiolite of Eastern Townships; : (5) Arc-related volcanics (Ordovician); (6) Felsic (dash) and gabbroic intrusions (Devonian to Carboniferous); (7) Siluro-Devonian metasediments; (8) Paleozoic sediments of the St. Lawrence Lowlands; - (9) Carbonate platform and overlying Ordovician flysch; (10) Taconic and Quebec allochthons; (11) Clastic rise prism of ancient western margin (dots) and Eocambrian rift volcanics; (12) Imbricate zone of ophiolite rocks and ancient western margin; (13) Syn- to post-ophiolite flyșch and arc-related metasediments; (14) Thrust fault; (A) Autochthonous domain, (B) external domain, (C) internal domain of St. Julien and Hubert (1975). 
placement of the ultramafic body with the associated underplated amphibolites and greenstone (Belvidere Mountain Formation) onto clastic rocks of the continental margin. The Lower Cambrian-Cambrian clastic rocks are represented by gneiss, schist, phyllite, and metagraywacke of the Hazen's Notch Formation and the Ottauquechee Formation. The Camels Hump Group (includes the Hazen's Notch Formation) and the Oak Hill Group in Quebec form the core of the Green Mountain-Sutton Mountain Anticlinorium, and overlie Pre-Cambrian basement in southern Vermont (Fig. 2). Structurally overlying the clastic Cambrian rocks are chlorite-rich phylite and schist, "cut by metaigneous dikes, of the Cambro-Ordovician (?) Stowe Formation.

\section{Previous Works}

Attention was first drawn to Belvidere Mountain when Judge M. E. Tucker found asbestos in the area on November 9, 1899 (Marsters, 1905). Early work in the area was done by V. F. Marsters (1904, 1905, 1906) who mapped serpentine, amphibolite; and schist at Belvidere Mountain. Although Marsters was primarily concerned with the geology, mineralogy, and origin of the serpentine and asbestos, his reports also include discussions of the general geology in the area, and both macroscopic and microscopic descriptions of the amphibolite. Marsters (1904, 1905, 1906) concluded that the serpentine was derived from a basic igneous rock, and that based on field and petrographic data, he could offer no suggestion of a protolith for the amphibolite.

Keith and Bain (1932) published a report concerning the occurrence of chrysotile asbestos as a fracture filling along torsion cracks and crush fractures in serpentinized peridotite, dunite, and 
pyroxenite in the vicinity of Belvidere Mountain. They also briefly discussed the general geology, named the Belvidere Mountain Amphibolite, and suggested that the Belvidere Mountain Amphibolite was derived from a diabase or pyroxene diorite.

Albee (1957) mapped the bedrock geology of the Hyde Park Quadrangle. He mapped the Belvidere Mountain Amphibolite as the upper member of the Camels Hump Group, and included both the amphibolite at Belvidere Mountain and greenstone south of the mountain as part of the Belvidere Mountain Amphibolite. Albee (1957) suggested a water-laid mafic volcanic detritus protolith for the Belvidere Mountain Amphibolite.

The previous structural and stratigraphic work in the region is mainly based on the comprehensive report of the geology of the upper Missisquoi Valley by Cady, Albee, and Chidester (1963), the work of Albee (1957), and the state map of Vermont (Doll et al., 1961). Cady et al. (1963) mapped nine formations in the region, as we1l as metagabbro sills, dikes, and ultramafic plutons. Cady et al. (1963) delineated the major structural features in the Belvidere Mountain area, and noted that a departure from the dominant northnortheast structural trend is evident just north of Belvidere Mountain where a series of east-west folds are exposed in the Cambrian rocks. Cady et al. (1963) also defined a hornblende isograd at Belvidere Mountain to distinguish greenschist facies from epidoteamphibolite facies rocks. This isograd is shown as a garnet isograd on the state map of Vermont (Doll et al., 1961).

Magnetic surveys by Murphy and Lacroix (1969) document the existence of unexposed ultramafic rock at Belvidere Mountain, as well 
as separate, subsurface ultramafics within the Missisquoi Valley Syncline.

Chidester and Cady (1972) discuss the origin of the ultramafic rocks in the Appalachians, and conclude that the ultramafic rocks in Vermont represent solid intrusions of mantle material into overlying continental crust and eugeosynclinal sediments.

The most recent reports in the area are by Laird and Albee (1975), Laird (1977), Anderson and Albee (1975), Labotka and Albee (1978), and Chidester, Albee, and Cady (1978). Laird (1977) did microprobe studies of the mineralogy of Cambrian to Devonian mafic rocks in the State of Vermont. She used her data to develop a polymetamorphic history of the rocks in Vermont. She also noted the occurrence of high pressure facies series metamorphism of the Belvidere Mountain Amphibolite at Tillotsen Peak (Figure 1). Laird (1977) concluded that the metamorphism of the Belvidere Mountain Amphibolite reflects two Ordovician events. Laird and Albee (1975) propose a high pressure Taconic metamorphic event in the area. Anderson and Albee (1975) used deformed quartz veins as markers to develop a structural and metamorphic history for northern Vermont. Thus, they defined two Ordovician events and two Devonian events. Labotka and Albee (1978) discussed the process of serpentinization at Belvidere Mountain. Chidester et al. (1978) provide a detailed study of the geology of the ultramafic rocks at Belvidere Mountain. They elevate the Belvidere Mountain Amphibolite to the Belvidere Mountain Formation. Chidester et al. (1978) interpret the protolith of the amphibolite and greenstone as a submarine volcanic detrital sediment. They conclude that the ultramafic rocks represent masses of solid 
mantle material intruded into continental crust and eugeosynclinal sediments during rifting and distension of the continental crust. Subsequent uplift in the eugeosyncline, during Early Ordovician time, resulted in transport of the ultramafic bodies to high levels in the eugeosynclinal pile (Chidester et a1., 1978).

Methods of Analysis

Mapping of this area was done by pace and compass methods at a scale of 1:20000 during the summers of 1977 and 1978. East-west traverses were done at 500 foot intervals throughout the area, and numercus north-south traverses were taken, thus establishing a grid system and allowing outcrops to be accurately located. In addition, most contacts were mapped where outcrop permitted, and inferred contacts were checked in the field. Structural data was collected from over 500 outcrops, and samples were collected for petrographic and chemica1 analyses.

Sixty thin sections were analyzed to determine the mineralogy and the relation of mineralogy to the minor structures. Major element analyses and trace element analyses were done for'forty-two samples of greenstone, fine grained amphibolite, and coarse grained amphibolite. The chemical analyses were done by Dr. Barry Doolan, using a Perkin Elmer 303 atomic absorption spectrometer for the major elements, and a Phillips PW 1220 x-ray fluorescence computerized spectrometer for the trace elements. High precision analyses for the major element oxides were obtained through bracketing of the sample between known higher and lower concentrations. For the trace elements, standards $\mathrm{BCR}-1, \mathrm{AGV}-1$, and $W-1$ were run as unknowns for a check on precision 
and accuracy. These analyses, the standard deviation, and the percent error are given in Appendix 2. The accuracy of the trace element analyses for $\mathrm{Cu}, \mathrm{Cr}$, and $\mathrm{Pb}$ appear dependent on concentration. The percent error greatly decreases as concentration increases. The percent error for most analyses is between 0 and $20 \%$. Although standards were not used to determine the accuracy for the major element oxides, an estimate can be made based on previous analyses from Memorial University. BCR-1 was run as an unknown by Kean and Strong (1975) and the analysis is given in Appendix 2. The percent error was calculated by this author, and is less than $10 \%$ for a11 oxides except $\mathrm{TiO}_{2}$ (less than $16 \%$ ).

\section{Acknowledgments}

Dr. Barry Doolan originally suggested the thesis problem, introduced me to field work, and supplied the chemical data for this study. He and Dr. Rolfe Stanley provided immense help, encouragement, and guidance throughout the study. In addition, financial support for the summer of 1978 was furnished through a U. S. G. S. grant to Dr. Stanley.

Special thanks are extended to Mary Thomas for her excellent field assistance, discussion, and continued enthusiasm for the project throughout the summers of 1977 and 1978. Peter Gale supplied valuable support, discussion, and criticism. I also thank the Vermont Asbestos Group for their cooperation, and Dr. A1fred Chidester for kindly furnishing his preliminary maps of Belvidere Mountain. 


\section{Chapter 2}

\section{STRATIGRAPHY}

\section{Introduction}

The rocks in this area have previously been mapped as a stratigraphic sequence "younging" from west to east based on the structural control of the Green Mountain Anticlinorium (Doll et a1., 1961; Cady et al., 1963). This stratigraphic sequence consists of, from base to top, the Cambrian Hazens Notch Formation, the Belvidere Mountain Amphibolite, and the Ottauquechee Formation. The Cambrian rocks are overlain by the Upper Cambrian-Lower Ordovician Stowe Formation. The ultramafic rocks were interpreted as Ordovician intrusives (Cady et a1., 1963).

The Camels Hump Group was defined by Cady (1956) as schist, gneiss, and quartzite lying between Precambrian rocks and the Ottauquechee Formation. Cady, Albee and Chidester (1963) named the Hazens Notch Formation for part of the Camels Hump Group in the upper Missisquoi Valley, and assigned a Lower Cambrian age to the Hazens Notch Formation since it lay west of and below the Ottauquechee Formation (Doll et al., 1961; Cady et al., 1963). Cady et al. (1963) correlated the Hazens Notch Formation with the Sutton schists (Clarke, 1934) in Quebec.

The Belvidere Mountain Amphibolite was named by Keith and Bain (1932) for the amphibolite on Belvidere Mountain. Albee (1957) mapped the greenstone south of Belvidere Mountain as part of the 
Belvidere Mountain Amphibolite. The Belvidere Mountain Amphibolite thus referred to greenstone and amphibolite at the top of the Camels Hump Group, below and west of the Ottauquechee Formation. Doll et al. (1961) and Cady et al. (1963) treated the Belvidere Mountain Amphibolite as the upper member of the Hazens Notch Formation. Chidester et al. (1978) elevated the Belvidere Mountain Amphibolite to the Belvidere Mountain Formation, and mapped coarse amphibolite, fine amphibolite, greenstone, and muscovite schist as members of that formation.

The Ottauquechee Formation includes phyllites, quartzite, and graywacke, and was first defined by Perry (1929) in southern Vermont: The Ottauquechee Formation was traced north to the Hyde Park Quadrangle by Brace (1953), Osberg (1956), and Cady (1956). Albee (1957) and Cady et al. (1963) correlated the Ottauquechee Formation with the lower Mansonville slates (Clark, 1934) in Quebec. The Ottauquechee Formation was correlated with the fossiliferous rocks of the Sweetsburg Group west of the Green Mountain Anticlinorium (Cady, 1960; Osberg, 1956) which contain a fauna in the Cedaria zone, assigned a Middle Cambrian age (Shaw, 1958):

The Stowe Formation (Cady, 1956) is assigned an Upper Cambrian-Lower Ordovician age by Cady et al. (1963) because it overlies the Ottauquechee Formation, and is correlated with the upper Mansonville slates in Quebec. Cady (1969) correlated the Stowe Formation with the Caldwell Group (Cooke, 1950) in Quebec.

In this study, the four previously defined formations are divided into fourteen mappable units (Plate I). The formation names are retained here, although the formations are interpreted to be 
tectono-stratigraphic packages of lithic assemblages separated by faults. In addition, the Belvidere Mountain Formation is here referred to as the Belvidere Mountain Complex and includes the ultramafic rocks at Belvidere Mountain. Rocks previously assigned to the Hazens Notch Formation are here mapped as four units: fine grained gneiss (wgn); rusty schist (rs); albite gneiss (agn); sericite schist (ss). The rocks previously mapped as the Belvidere Mountain Amphibolite and the Belvidere Mountain Formation are here referred to as the Belvidere Mountain Complex and are divided into four units: coarse grained amphibolite (bac); fine grained amphibolite (baf); greenstone (bgs); muscovite schist (mus). The ultramafic rocks (oud, outc) are-considered part of the Belvidere Mountain Complex. The Ottauquechee Formation is divided into five units: green phyllite (grp); gray phyllite (gp); black carbonaceous phyllite (bcp); phyllitic graywacke (pgw); black and rusty schist (rbs). Rocks previously mapped as the Stowe Formation are here mapped as undifferentiated green and tan schists and-phyllites (ucs), and metaigneous dikes. A correlation chart based on the previous works, and a comparison with the units defined in this study, is given in Figure 3.

The map pattern developed, based on the division of the previously mapped stratigraphy into fourteen units, shows the stratigraphy as disrupted and discontinuous (Plate I). There is little evidence for establishing a stratigraphic sequence in the Belvidere Mountain area: primary sedimentary features are not present in the multiply deformed rocks; consistent contact relationships are not present; most contacts are not exposed; units are repeated and truncated by folds and faults. In some cases it is possible to 


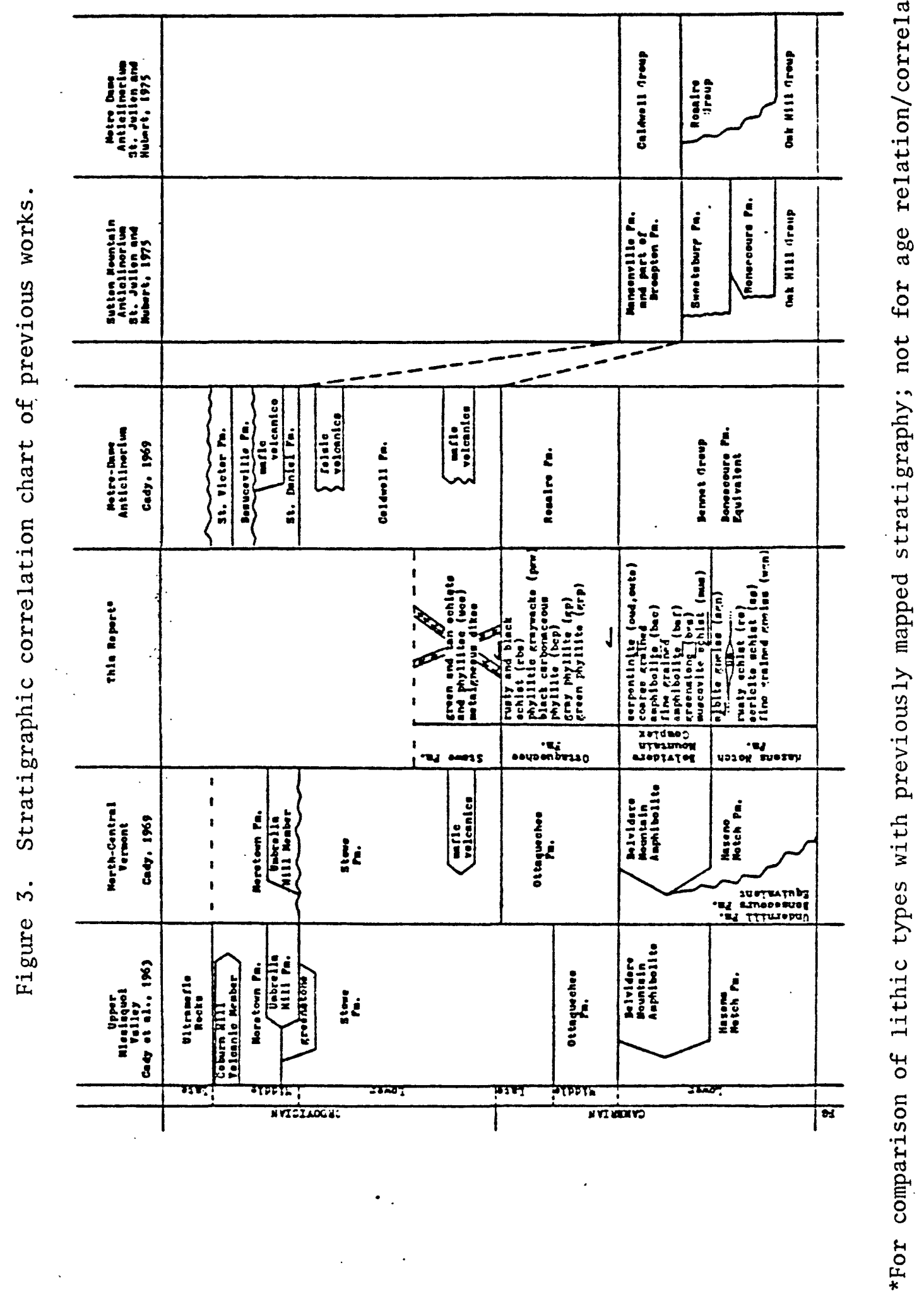


determine which units are presently structurally on top of other units. The rocks in this area are therefore described from west to east without implying a stratigraphic sequence. This study concentrated on rocks previously mapped as the Hazens Notch Formation and the Belvidere Mountain Formation. The rocks previously mapped as the Ottauquechee Formation and the Stowe Formation are therefore only discussed briefly.

Fault contacts in this area are defined on the basis of truncation of units along a common surface, truncation of fold structures along a surface, the presence of isolated rock types along a contact (fault slivers), and visible fault surfaces marked by slickensides and/or highly contorted, thin ( $1 \mathrm{~cm}$ to $1 \mathrm{~m}$ ) zones of talc. The faults are discussed in detail in Chapter 3 . Where there is no evidence for a fault contact, and the units appear lithically gradational, the contact is considered to be depositional. In addition, a contact may be fairly sharp, but is still considered depositional due to the lack of any evidence to the contrary.

\section{Hazens Notch Formation}

The Hazens Notch Formation comprises the lowest structural package in the Belvidere Mountain area. The western extent of the Hazens Notch Formation is outside of the study area. The rocks of the Hazens Notch Formation are fine grained gneiss (wgn), rusty schist (rs), sericite schist (ss), and albite gneiss (agn). Isolated bodies of serpentinite and talc-carbonate rock occur along the rusty schist-albite gneiss contact, and suggest that these two rocks are in fault contact. The Hazens Notch Formation is structurally overlain by the Belvidere Mountain Complex. 
The rocks of the Hazens Notch Formation are derived from shales, sandy shales, and quartzo-feldspathic rocks originally deposited as clastic sediments in a continental margin environment.

Fine grained gneiss (wgn). The gneiss is a fine grained $(<1 \mathrm{~mm})$, white and gray-green banded, quartz-sericite-albite gneiss. Quartzo-feldspathic bands, 3-5 mm wide, altemate with sericitechlorite rich bands approximately $1 \mathrm{~mm}$ wide. The rock has a granular or sugary texture.

In outcrop, the gneiss weathers to a light gray color. The dominant foliation in the gneiss is the compositional banding, and in the phyllitic bands, a finely spaced cleavage which parallels the compositional layers.

In map pattern, the fine grained gneiss occurs as three bands, repeated by folding, lying within the rusty schist (rs). The contact between the gneiss and the rusty schist is not exposed in the study area, although the contact is considered depositional.

The fine grained gneiss is exposed on a low ridge just east of the cemetery on Route 118, and near the roadside north of the cemetery (P1ate II, Loc. 1, 2).

Rusty schist (rs). The gray and rusty schist is a fine grained, carbonaceous, quartz-sericite-albite schist (Table 1). In some outcrops (e.g., Loc. 270, Plate II), the schist is coarser grained (1-3 mm) and albite occurs as porphyroblasts. The schist is a dark gray, rusty, and white banded schist which commonly displays three foliations. Transposed layering, developed paralle1 to the dominant slip cleavage (S2), is defined by chlorite-sericite rich and quartz-feldspar rich bands up to $1 \mathrm{~cm}$ wide. 
Table 1

Modal Mineralogy Based on 1000 Points per Thin Section

\begin{tabular}{|c|c|c|c|c|c|c|c|}
\hline Sample & $\begin{array}{l}\text { bgs } \\
105 \\
\end{array}$ & $\begin{array}{l}\text { bgs } \\
173 \\
\end{array}$ & $\begin{array}{l}\text { bgs } \\
298 \\
\end{array}$ & $\begin{array}{l}\text { bgs } \\
321 \\
\end{array}$ & $\begin{array}{l}\text { baf } \\
257\end{array}$ & $\begin{array}{l}\text { baf } \\
307 \\
\end{array}$ & $\begin{array}{l}\text { baf } \\
547 \\
\end{array}$ \\
\hline $\mathrm{Ab}$ & 30.4 & 21.6 & 15.5 & 25.7 & 7.3 & 8.5 & 30 . \\
\hline Amph & 17.4 & 26.7 & 39.9 & 22.2 & 44.2 & 55.6 & 00 \\
\hline Ep & 19.3 & 23.7 & 25.0 & 13.0 & 36.4 & 24.8 & \\
\hline Ch1 & 29.3 & 20.3 & 12.8 & 31.2 & 8.5 & 3.4 & 32.0 \\
\hline Cc & --- & 2.2 & 0.1 & 7.2 & --- & --- & 10.6 \\
\hline Qtz & ---- & 0.3 & 1.1 & ---- & 1.3 & 1.4 & -- \\
\hline $\mathrm{Ga}$ & ---- & ---- & ---- & ---- & ---- & 2.2 & 0 . \\
\hline Biot & 0.5 & ---- & 0.1 & ---- & 1.1 & 1.2 & --- \\
\hline Musc/ser & $\ldots$ & --- & --- & --- & --- & --- & -- \\
\hline Sph & 3.1 & 4.9 & 5.4 & 0.7 & 3.1 & 2.9 & 2.5 \\
\hline Tourm & ---- & ---- & --- & --- & ---- & --- & --- \\
\hline $0 p$ & $\operatorname{tr}$ & 0.3 & $\operatorname{tr}$ & tr. & 2.1 & --- & 0. \\
\hline
\end{tabular}

\begin{tabular}{|c|c|c|c|c|c|c|c|}
\hline Sample & $\begin{array}{l}\text { bac } \\
250 \\
\end{array}$ & $\begin{array}{l}\text { bac } \\
256 \\
\end{array}$ & $\begin{array}{l}\text { rs } \\
270 \\
\end{array}$ & $\begin{array}{l}\text { rs } \\
458 \\
\end{array}$ & $\begin{array}{l}\text { agn* } \\
326\end{array}$ & $\begin{array}{l}\text { ss * } \\
98\end{array}$ & $\begin{array}{l}\text { mus } \\
419 \\
\end{array}$ \\
\hline$A b$ & 5.6 & 7.3 & 29.1 & 4.2 & 33 & 27 & 2 \\
\hline Amph & 57.4 & 47.3 & ---- & 0.4 & $\ldots$ & --- & $-\cdots$ \\
\hline Ep & 20.0 & 24.7 & 3.0 & 0.2 & 9 & $-\cdots$ & 10 \\
\hline Ch 1 & 5.6 & 10.7 & 46.9 & 19.0 & 5 & 6 & 10 \\
\hline Cc & ---- & $-\cdots$ & --- & 2.4 & -... & $-\cdots$ & $-\cdots$ \\
\hline Qtz & 6.6 & 4.9 & 4.8 & 39.6 & 35 & 33 & $\cdots-$ \\
\hline $\mathrm{Ga}$ & 2.4 & $-\cdots$ & 0.2 & 0.1 & tr. & $\cdots$ & $-\cdots$ \\
\hline Biot & 1.6 & 2.4 & 0.6 & 0.1 & $\ldots$ & -..- & $\ldots$ \\
\hline Musc/ser & $-\cdots$ & 1.3 & 0.2 & 32.2 & 15 & 28 & 77 \\
\hline Sph & 0.7 & 1.4 & 6.9 & 1.3 & 1 & $\cdots$ & --- \\
\hline Tourm & --- & $-\cdots$ & ---- & $-\cdots$ & --- & --- & 1 \\
\hline Op & 0.1 & tr. & 8.3 & 0.5 & 2 & 6 & - \\
\hline
\end{tabular}

Sample

Antigorite

Brucite

Carbonate

Chromite-magnetite

Magnetite

Olivine
Serpentinite**

$\begin{array}{cr}94 & 13 \\ -- & <1 \\ -1 & -- \\ 6 & 1 \\ -- & --\end{array}$

86

* mode based on visual estimate

**mode from Cady, Albee, and Chidester (1963, p. 34) 
The contact between the rusty schist and the albite gneiss (agn) is gradational in the field over a 1-2 meter distance. Near the contact with the albite gneiss, the rusty schist is more massive and albitic, with albites occurring as porphyroblasts. The two units are interlayered at the contact. However, the map pattern, and the presence of isolated bodies of talc-carbonate rock and serpentinite along the contacts of these units in the vicinity of Schofield Ledges, suggests a fault contact. The contact is exposed in two streams on the southwest slopes of Belvidere Mountain, and at Schofield Ledges (Plate II, Loc. $3,4,5,6)$.

The contact between the greenstone (bgs) and the rusty schist is exposed at locations 7,8 , and 9 shown on Plate II. The rusty schist is albitic at the contact. The schist also occurs as $10 \mathrm{~cm}$ to $1 \mathrm{~m}$ wide infolded layers in the greenstone. The contact between the rusty schist and the greenstone generally is parallel to the dominant slip cleavage (S2) in the schist (Fig. 4). Several isolated bodies of talc-carbonate rock and quartz-carbonate rock occur along the rusty schist-greenstone contact (e.g., Plate II, Loc. 31, 32). The contact between the rusty schist and the greenstone is interpreted as a fault contact based on the presence of these isolated bodies, plus the truncation by the greenstone of the underlying stratigraphy, and the truncation of the folded greenstone-muscovite schist contact along the rusty schist-albite gneiss contact.

The rusty schist is in fault contact with the serpentinite (P1ate II, Loc. 10), and appears as a fault sliver at the contact of the greenstone and the fine grained amphibolite (Plate II, Loc. 11). 


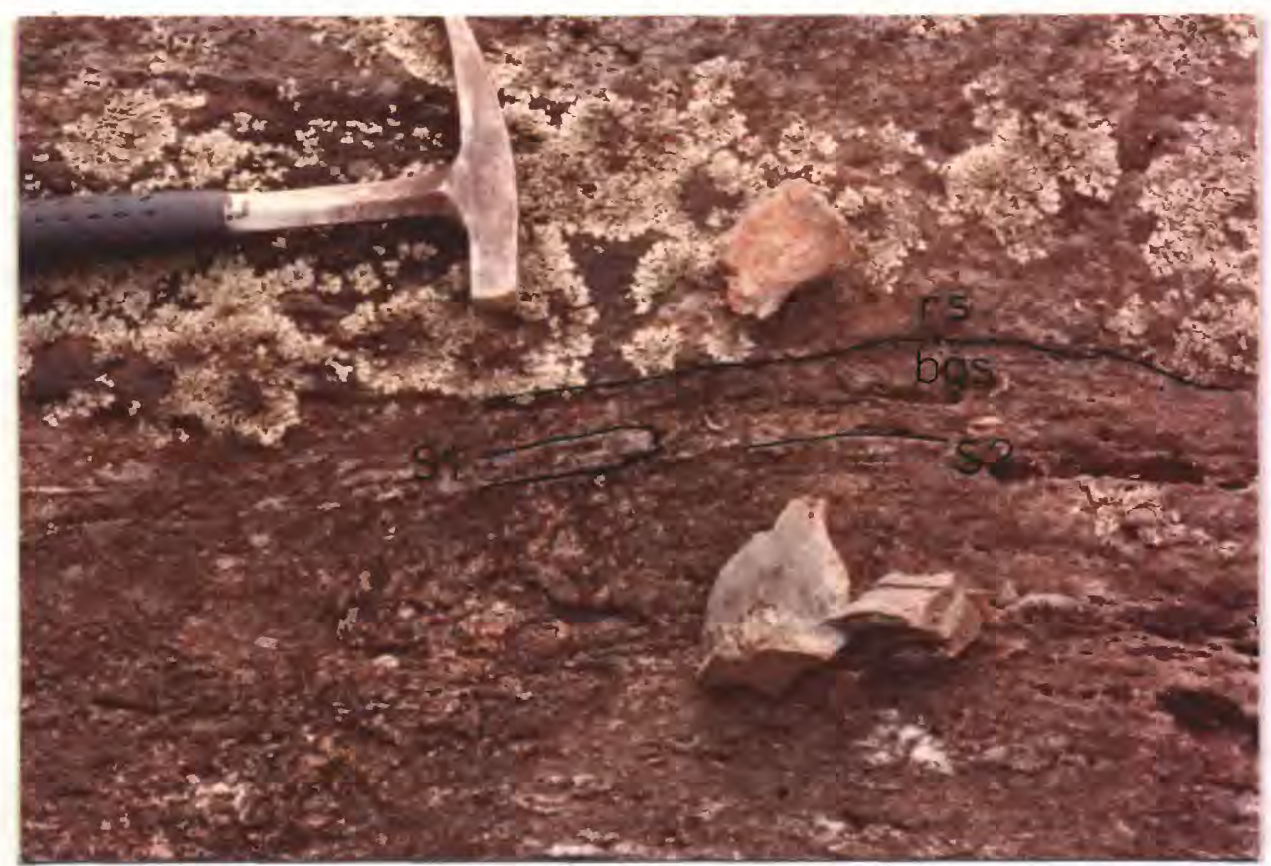

Figure 4. Contact of the rusty schist (rs) and the greenstone (bgs) just south of location 221 on Plate II. Contact is parallel to the dominant $\mathrm{S} 2$ schistosity. F2 isoclinal folds of the SI foliation are visible in the greenstone. 
The western extent of the rusty schist was not mapped as it is outside the limits of the field area.

Several good exposures of the rusty schist occur near the dirt road east of Route 118 (Plate II, Loc. 12, 13).

Albite gneiss (agn). The albite gneiss is a fine to medium grained, massive, light gray banded rock, with albites in relief on the weathered surface (Table 1). The banding in the gneiss is defined by variations in the proportions of quartz, albite, sericite, and chlorite. Thus, the $0.5 \mathrm{~cm}$ to $3 \mathrm{~cm}$ wide layers are either phyllitic, schistose, or massive.

Where exposed, the contacts of the albite gneiss are parallel to the gneissic layering. The albite gneiss and the rusty schist are interlayered at the contact, except in the vicinity of Schofield Ledges where serpentinite separates the two units (Plate II, Loc. 14). The contact of the albite gneiss and the greenstone is sharp (within $5 \mathrm{~cm}$ ), with each unit retaining its unique character. The contacts of the albite gneiss with the muscovite schist, the coarse grained amphibolite, and the serpentinite are not exposed in the area. However, the folded contact of the greenstone and muscovite schist is truncated against the albite gneiss, thus suggesting a fault contact. Furthermore, the presence of thin, discontinuous lenses of rusty schist and coarse grained amphibolite along the serpentinite-albite gneiss contact near the summit of Belvidere Mountain suggests a fault contact.

The gneiss is on top of the rusty schist and below the greenstone and serpentinite. The estimated thickness of the albite gneiss, assuming $100 \%$ repetition by folding and thus removing that factor, is 80 meters (250 feet). 
The best exposures of the albite gneiss are at Schofield Ledges, on the Long Trail, and in several stream beds on the southwest slopes of Belvidere Mountain (Plate II, Loc. 15, 16, 17,6).

Sericite schist (ss). The sericite schist is a silver-gray green, phyllitic schist composed of quartz, sericite, albite, chlorite, and magnetite (Table 1). In some outcrops (e.g., Plate II, just east of Loc. 109), the schist is finely laminated due to alternate sericitic and quartzofeldspathic bands. The schist weathers gray, and magnetite grains are in relief on the weathered surface.

Where exposed, the contact between the sericite schist and the - greenstone paralle1s the fine laminations in the schist and the banding in the greenstone. At location 18 on Plate II, the contact is marked by a contorted quartz-chlorite-magnetite rock, and at location 19 (Plate II) an outcrop of quartz-carbonate rock is present at the contact.

The estimated maximum thickness of the sericite schist, removing the assumed repetition by folding, is 65 meters (200 feet). The sericite schist is exposed on Route 118, approximately 0.5 mile north of Eden, and in the open field one mile north of Eden (Plate II, Loc. 20).

\section{Belvidere Mountain Complex}

The Belvidere Mountain Complex is comprised of serpentinized ultramafic rocks structurally overlying coarse and fine grained amphibolites, greenstone, and muscovite schist. Fault contacts between these units are common, and the entire complex is in fault contact with the underlying Hazens Notch Formation. 
The estimated thickness of the Belvidere Mountain Complex, removing the effect of $100 \%$ repetition by folding, is approximately 500 meters (1500 feet). The areal extent of the Belvidere Mountain Complex is mainly confined to Belvidere Mountain, although greenstone is exposed to the south. The protoliths for the rocks of the Belvidere Mountain Complex are ocean floor basalt/gabbro (see Ch. 4 and 5) capped by serpentinized ultramafic rocks (mantle). The muscovite schist is most probably derived from deep water shale or clay.

Muscovite schist (mus). This unit is a silver-blue, medium grained, tourmaline bearing muscovite schist. The rock is composed almost entirely of muscovite, with much less chlorite, epidote, albite, and tourmaline (Table 1). Some subhedral tourmaline grains, up to $5 \mathrm{~mm}$ in length, are visible in outcrop.

The muscovite schist contains folded, discontinuous layers and lenses of greenstone (bgs), coarse grained amphibolite (bac), and talc phyllite. In addition, the greenstone and the two amphibolites occur in the muscovite schist as rounded to subrounded blocks ranging in size from $3 \mathrm{~mm}$ to $20 \mathrm{~cm}$ in diameter (Fig. 5). The blocks contain a single foliation which is either continuous with or discontinuous with the foliation in the muscovite schist. The boundaries of the layers, lenses, and blocks with the muscovite schist host-rock vary from sharp to gradational and obscure. In some outcrops, the foliations in the muscovite rock are clearly defined, and systematic fold patterns are visible (Plate II, west of Loc. 300). In other outcrops, the rock appears contorted, with no systematic pattern visible (Plate II, northeast of Loc. 514). 


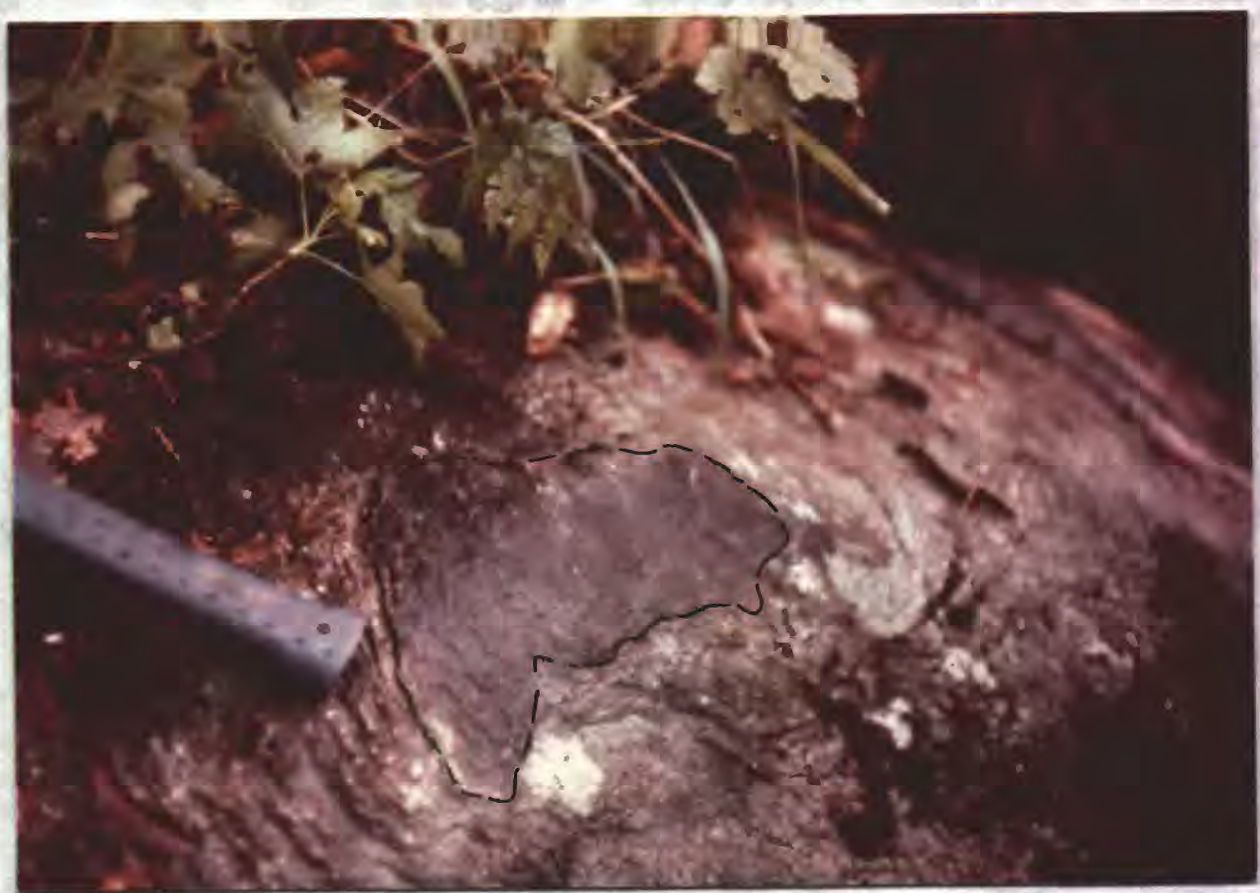

Figure 5. Block of greenstone (bgs) in the ruscovite schist. Location 419 on Plate II. 
The contact between the muscovite schist and the greenstone is a we11 defined fault contact, marked by slivers of coarse grained amphibolite, fine grained amphibolite, and talc phyllite (Plate II, Loc. $21,22,23,24,25,26)$. The contact is discussed in detail in Chapter 3. The contacts of the muscovite schist with the serpentinite and the albite gneiss are not exposed.

The maximum estimated thickness of the muscovite schist, assuming $100 \%$ repetition by folding and removing that effect, is 25 meters (75 feet).

Exposure of the muscovite schist is limited to the area just southwest of the summit of Belvidere Mountain. However, good exposures are easily accessible west of the dirt road which leads to the old quarry (Plate II, Loc. 27).

Greenstone (bgs). The greenstone is a tan weathering, fine grained, gray-green rock composed of chlorite, actinolite, albite, and epidote, with lesser amounts of biotite, calcite, sericite, quartz, sphene, pyrite, and magnetite (Table 1).

The unit includes a homogeneous, schistose greenstone, an albitic greenstone, and a banded greenstone. The albitic greenstone is a fine grained rock with albites in relief on the weathered surface. The banded greenstone is recognized on the basis of $0.5 \mathrm{~mm}$ to $4 \mathrm{~mm}$ wide light and dark green bands. The 1 ighter bands result from a high percentage of epidote and albite. The textural variations do not define separable map units, and occur together within a single outcrop. The greenstone is discussed in detail in Chapter 4.

The contacts of the greenstone with all units in contact with it are interpreted as faults. Descriptions of these contacts are 
given here and in Chapter 3. The contacts of the greenstone with the fine grained amphibolite, coarse grained amphibolite, and serpentinite are definitive fault contacts. The greenstone appears gradational with the fine grained amphibolite, but the only contact exposed is a fault contact with slivers of serpentinite and coarse grained amphibolite (Plate II, Loc. 11). The contact between the greenstone and the serpentinite is marked by thin talc zones, and slivers of coarse grained amphibolite (Plate II, Loc. 28, 29). At the contact, the greenstone is more foliated, with finely-spaced rusty cleavage planes.

The contact between the greenstone and the muscovite schist is a fault contact. Talc zones, and slivers of fine grained and coarse grained amphibolite are exposed along the contact (Plate II, Loc. 21-26). These contacts are discussed in detail in Chapter 3.

The contacts of the greenstone with the albite gneiss (agn), rusty schist ( $r s$ ), and sericite schist (ss) are interpreted as fault contacts for several reasons: the folded fault contact of the greenstone with the muscovite schist is truncated by the albite gneiss, and the continuation of this contact to the south shows the albite gneiss-rusty schist contact truncated by the greenstone; isolated bodies of talc-steatite and quartz-carbonate rock are present at the contacts of the greenstone with the rusty schist and with the sericite schist; the greenstone is in contact with three different units along its western contact.

The contact of the greenstone with the albite gneiss is exposed in the stream bed near the summit of Belvidere Mountain (Plate II, Loc. 30). The contact parallels the gneissic layering in the albite gneiss. The greenstone is albitic at the contact. 
The greenstone is albitic at the contact with the rusty schist. Where exposed, the contact is parallel to the dominant slip cleavage in the rusty schist (Fig. 2). Approximately $3 \mathrm{~km}$ (2 miles) north of Eden, the contact is marked by quartz-carbonate and talc-carbonate rock (Plate II, Loc. 31, 32). Numerous other quartz-carbonate bodies are present east of this contact, and are surrounded by greenstone (P1ate II, Loc. 33, 34, 35, 36).

The contact between the greenstone and the sericite schist has been previously discussed. Contacts of the greenstone with the black, carbonaceous phyllite (bcp) and the phyllitic graywacke (pgw) are not exposed in the area. However, the discontinuous occurrences of black, carbonaceous phyllite along the contact between the greenstone and the phyllitic graywacke (Plate I) support a fault interpretation for this contact.

The estimated maximum thickness of the greenstone, assuming $100 \%$ repetition by folding and removing this effect, is 80 meters (250 feet).

Aside from locations already mentioned, the greenstone is exposed approximately 2.2 meters ( 1.5 miles) north of Eden on Route 118 .

Fine grained amphibolite (baf). The amphibolite is a fine grained, blue-gray to dark gray rock composed of amphibole and epidote, with lesser amounts of albite, garnet, chlorite, quartz, and sphene (Table 1). The fine grained $(<3 \mathrm{~mm})$ amphibolite is distinguished in the field from the greenstone by its darker color, the presence of visible amphibole laths, and its more massive nature. This unit is distinguished from the coarse grained amphibolite by its finer grained texture. 
The contact between the fine grained amphibolite and the coarse grained amphibolite is gradational. Southeast of the summit of Belvidere Mountain (Plate II, Loc. 37) the contact between the two amphibolites is marked by a gradual change in grain size, and by interlayering over a $15 \mathrm{~m}$ distance. In this area, the fine grained amphibolite contains sma11, conspicuous garnet porphyroblasts. The contact is also exposed near the base of Belvidere Mountain, southeast of the VAG waste piles (Plate II, Loc. 38). The fine grained amphibolite does not contain conspicuous garnet porphyroblasts in this area, a1though garnet is visible in thin section.

Although the fine grained amphibolite and the greenstone appear gradational, and are sometimes difficult to distinguish in the field, the only exposed contact is the fault contact previously discussed (Plate II, Loc. 11). At this contact, the amphibolite is a schistose, fine grained garnet amphibolite. The fine grained amphibolite also occurs along the contact between the greenstone and the muscovite schist (P1ate II, Loc. 25, 39).

At the contact between the fine grained amphibolite and the serpentinite (P1ate II, Loc. 40), the amphibolite is schistose, and contains round pods of extremely coarse grained actinolite-chlorite rock (Fig. 6). The foliation in the amphibolite wraps around the actinolite-chlorite pods.

The maximum estimated thickness of the amphibolite, assuming $100 \%$ repetition by folding, is 35 meters (110 feet).

The most easily accessible exposures of the fine grained amphibolite are at the summit of Belvidere Mountain, and on the VAG property in the southeast. The amphibolite is discussed in detail in Chapter 4. 


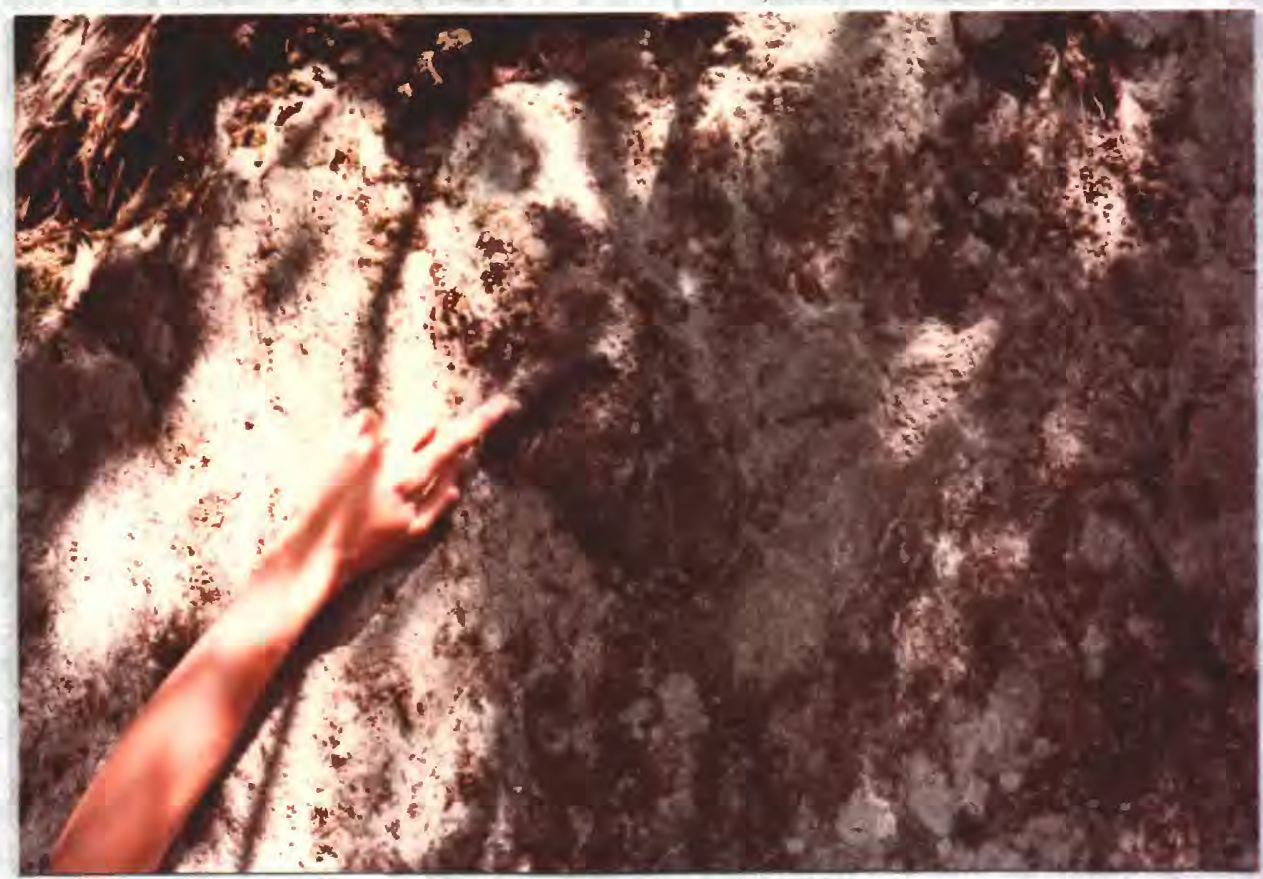

Figure 6. Chlorite-actinolite pod in the fine grained amphibolite (Location 547. Plate II). 
Coarse grained amphibolite (bac). The amphibolite is a dark gray, coarse grained amphibolite composed of amphibole, epidote, and garnet with lesser amounts of albite, chlorite, sphene, sericite, biotite, and calcite (Table 1). Calcite is present as aggregates, thus some outcrops have white speckles. Garnet is present as pale red or green porphyroblasts, depending on the amount of alteration to chlorite. In some outcrops the amphibolite is banded (Plate II, Loc. $41,250)$. The bands are defined by slight variation in grain size, and by the presence or absence of garnet. The amphibolite is discussed in detail in Chapter 4.

The contact between the coarse grained amphibolite and the fine grained amphibolite is gradational, as previously discussed. The contact between the amphibolite and the serpentinite is not exposed, but garnet is particularly abundant in the amphibolite close to the contact (P1ate II, Loc. 41). The amphibolite occurs as fault slivers along the contacts between the greenstone with the serpentinite and the greenstone with the muscovite schist (Plate II, Loc. 29, 21, 24, $25,26)$.

The amphibolite slivers along the greenstone-muscovite schist contact have a slightly different appearance. The amphibolite is dark gray, and contains one cm wide, yellow-green, epidote-rich lenses and discontinuous layers. The layers are contorted, and sharply truncated and offset along thin shears within the amphibolite. Garnet is absent.

The maximum estimated thickness of the amphibolite, assuming $100 \%$ repetition by folding, is 60 meters (200 feet). 
The best exposures of the coarse grained amphibolite are at the summit of Belvidere Mountain, and on the VAG property south of the waste piles (Plate II, Loc. 38).

Ultramafic rocks (oud, outc). U1tramafic rocks occur as discontinuous lenses within the Hazens Notch Formation (mostly outside the field area), as fault slivers along contacts of the Belvidere Mountain Complex and the Hazens Notch Formation, and between units of the Belvidere Mountain Complex. The most abundant occurrence of ultramafic rock in the study area is the $450 \mathrm{~m}$ thick (Chidester et al., 1978) sheet which structurally overlies the amphibolites and greenstone on Belvidere Mountain. Ultramafic rocks in the Belvidere Mountain area consist of the following rock types: serpentinized peridotite and dunite (oud); talc-carbonate rock and steatite (outc); quartz-carbonate rock; talc phyllite.

The serpentinite is a brown to white weathering, fine grained, massive, green rock composed almost entirely of antigorite (Table 1). At the contact with the greenstone (e.g., Loc. 28, Plate II), the serpentinite is cut by numerous thin, intersecting slip surfaces which do not extend into the greenstone. In some localities along the western and northern contacts, the serpentinite is schistose. The contacts with the greenstone and with the rusty schist are commonly marked by one to three feet wide talc phyllite zones (Plate II, Loc. $28,29,10)$

South of Belvidere Mountain, at Schofield Ledges, talc-carbonate rock, quartz-carbonate rock, and sheared serpentinite are in contact with the albite gneiss. The talc-carbonate rock is extremely 
soft, and weathers to a rusty powder. On a fresher surface, the rock is light gray with rusty carbonate (magnesite) grains.

The quartz-carbonate rock is also present at the contact of the greenstone with the rusty schist (e.g., Plate II, Loc. 31), and at the greenstone-sericite schist contact (Plate II, Loc. 19). Several isolated outcrops are in contact with the greenstone (P1ate II, Loc. $33,34,35,36)$. The quartz-carbonate rock in these southern locations occurs as flat-1ying outcrops which weather to a rusty powder.

The reader is referred to Chidester et a1. (1978) and Cady et al.: (1963) for a complete discussion of the ultramafic rocks at Belvidere Mountain.

\section{Ottauquechee Formation}

The Ottauquechee Formation consists of five units: green phyl1ite; gray phyl1ite; black, carbonaceous phyllite; phyl1itic graywacke; rusty and black schist. The areal extent of the formation is limited to a narrow belt of poorly exposed outcrop east of Belvidere Mountain. The ottauquechee Formation is in fault contact with both the underlying Belvidere Mountain Complex and the overlying Stowe Formation.- The estimated thickness of the Ottauquechee Formation in the study area is 320 meters (1000 feet).

The rocks of the Ottauquechee Formation are derived from shales and graywackes representing clastic sediments of a continental margin environment (continental slope/rise deposits).

Green phyllite (grp). The phyllite is a light green, quartzsericite-chlorite phyllite with rusty cleavage planes. The rock weathers to a rusty brown color. Two foliations are visible in out- 
crop. The early foliation is a finely spaced cleavage which is overprinted by a crenulate schistosity. The foliations give the rock a finely ribbed appearance.

Only one outcrop of the green phyllite was observed. The phyllite is exposed south of the entrance to the VAG quarry, just west of the black, carbonaceous phyllite (Plate II, Loc. 42).

Gray phyllite (gp). The gray phyllite is a dark gray, quartzsericite phyllite with quartz veins parallel to the dominant schistosity. The gray phyllite is interlayered with massive gray quartzite.

The gray phyllite is distinguished from the black, carbonaceous phyllite by its lighter color, lower carbon content, and lack of pyrite. The contacts of the gray phyllite are not exposed. The phylite is exposed on Hadley Mountain (Plate II, Loc. 43)

Black, carbonaceous phyllite (bcp). The black phyllite is exposed as low lying outcrops along the base of Hadley Mountain (Plate II, Loc. 44). The rusty weathering, sericite-quartz phyllite is black in color, graphitic, and contains pyrite. In most outcrops, the pyrite is weathered, leaving cubic spaces in the phyllite. The contacts of the phyllite are not exposed although they appear to parallel the early cleavage.

The phyllite is similar to the rusty schist of the Hazens Notch Formation. The separation of the two units is based on the same criteria as in previous works: the more phyllitic nature of the black, carbonaceous phyllite; the higher carbon content of the 
phyllite; less albite in the phyllite (Cady et a1., 1963). These criteria are generally reliable, although thin phyllitic layers in the rusty schist are inseparable from the black phyl1ite.

Phyllitic graywacke (pgw). The phyllitic graywacke is tan to gray in color. The rock is composed of rounded to angular grains, up to $2 \mathrm{~cm}$ in diameter, of quartz, blue quartz, and feldspar in a fine grained matrix of quartz, sericite, and chlorite. Some of the larger grains are fractured and recrystallized as aggregates along the fractures. The feldspar present is albitic plagioclase. The phyllitic graywacke is also exposed on The Knob, where in addition to the previously stated mineralogy, it contains detrital quartzite fragments. Thin phyllitic layers alternate with the coarser clastic layers. Near the contact with the greenstone, the phyllitic layers are more closely spaced, the clastic grains are elongate and flat, and the clastic grains are smaller in size. Discontinuous lenses of black, carbonaceous phyllite occur along the contact of the greenstone and phyllitic graywacke. These features lend support to a fault interpretation for this contact. The contact with the greenstone parallels the phyllitic layers in the graywacke. The contacts of the phyllitic graywacke with the black, carbonaceous phyllite (bcp), the gray phyllite (gp), and the green and tan schists and phyllites (ucs) are not exposed in the area.

The phyllitic graywacke is exposed west of The Knob, and on a smal1 knol1 4,500 feet north of Eden (P1ate II, Loc. 45, 46, 47).

$$
\text { Rusty and black schist (rbs). Several outcrops of rusty, }
$$
black and white thinly banded, quartz-sericite schist are present 
along the contact between the black, carbonaceous phyllite and the Stowe Formation (Plate II, Loc. 48). The rusty and black schist is interlayered,with the green and tan schists and phyllites at the contact. This unit differs from the rusty schist ( $r s$ ) in that it is finer grained, lacks albite porphyroblasts, is not graphitic, does not contain pyrite, and is more finely banded.

\section{Stowe Formation}

The Stowe Formation, exposed on Hadley Mountain, is comprised of green and tan schists and phyllites cut by metaigneous mafic dikes. The Stowe Formation is in fault contact with the underlying tectonostratigraphic package--the 0ttauquechee Formation. The eastern extent of the Stowe Formation is outside of the study area.

The schists and phyllites are most probably derived from deep water clastic sediments and volcanogenic detritus deposited upon a rifted continental margin.

Green and tan schists and phyllites (ucs). The rocks on the west flanks of Hadley Mountain are silvery green and tan chloritesericite-quartz schist and phyllite. The various rock types occur as separate outcrops, as well as interlayered within the same outcrop. The schist is slightly massive, and is banded $(1 \mathrm{~cm})$-in shades of green, tan, and white. Quartz veins are present parallel to the early foliation in the schists and phyllites. The schists and phyllites are not separated as different units on Plate $I$.

The contact of the green and tan schists and phyllites with the rocks to the west is interpreted as a fault contact, based on truncation of units, and the absence of dikes to the west. In addi- 
tion, it should be noted that the stratigraphy and geology on Hadley Mountain is more complex than that depicted on Plate I.

Metaigneous dikes. Several mafic metaigneous dikes (metadiabase to metagabbro) are present within the schists and phyllites on Hadley Mountain. The dikes are conspicuously absent in any rocks to the west, although they occur within $30 \mathrm{~m}$ (100 feet) of the contact of the schists and phyllites (ucs) with the gray phyllite and phyllitic graywacke of the ottauquechee Formation. The dikes vary in texture from fine to medium grained, and contain two faint foliations.

Summary and Discussion

The assignment of the units in this area-to the previously interpreted stratigraphic sequence "younging" from west to east (Cady et a1., 1963; Doll et a1., 1961; Albee, 1957; Chidester et a1., 1978) must be questioned since there are no definitive sedimentologic or stratigraphic criteria which establish such a sequence.

The map pattern, based on the division of the previously mapped stratigraphy, shows the stratigraphy as discontinuous. Numerous faults (see in addition Chapter 3) defined by truncation of units along a common surface, fault slivers, truncation of folds along a surface, and slickensided surfaces are exposed in the Belvidere Mountain area. The evidence presented here, as we 11 as structural data (Chapter 3), does not support a stratigraphic sequence, with conformable contacts, of formations which young from west to east. However, the area is best divided into four major tectono-stratigraphic packages which do coincide with the previously mapped formations: These 1ithic and structural packages are separated by faults, and 
fault contacts are also present within the packages, thus making the determination of original age relationships difficult.

The tectono-stratigraphic packages (from west to east) are: schists and gneisses of the Hazens Notch Formation; metamorphosed mafic rocks (bgs, baf, bac), ultramafic rocks (oud, outc), and muscovite schist of the Belvidere Mountain Complex; phyllites and graywacke (grp, gp, bcp, pgw, rbs) of the Ottauquechee Formation; green and tan schists and phyllites (ucs) of the Stowe Formation cut by metaigneous mafic dikes. Within the Hazens Notch Formation, the contacts are considered depositional except the contact of the albite gneiss with the rusty schist (marked by discontinuous bodies of metamorphosed ultramafic rock): All contacts within the Belvidere Mountain Complex are fault contacts, with the possible exception of the coarse grained amphibolite-fine grained amphibolite contact. Within the ottauquechee Formation, the contact of the phyllitic graywacke with the phyllites is interpreted as a fault contact, and the contacts between the phyllites are considered depositional (grp, gp, bcp). No fault contacts were recognized within the green and tan schists and phyllites of the Stowe Formation. 
Chapter 3

STRUCTURAL GEOLOGY

\section{Introduction}

Four fold generations are recognized in the study area, based on the superposition of minor folds and foliations within separate outcrops, and the correlation of the minor structures throughout the area. The correlation of the minor structures is based on similarity in orientation, systematic change in orientation, similarity in style, and superposed structures. The superposed relations are also exemplified by the map pattern. The fold generations are referred to as F1, F2, F3, and F4 in this study. The associated foliations are referred to as S1, S2, and S3. No foliation is associated with the F4 fold event in this area.

Faults in this area were delineated on the basis of truncations of units along a common surface, truncations of major structures along a common surface, and the recognition of fault surfaces in the field (sheared zones, fault slivers, slickensides, truncated minor structures). The faults pre-date F2 folds, and are pre- to syn-F1.

The area is treated as three subareas for the purpose of analysis and comparison. Subarea 1 is north of Schofield Ledges. Subarea 2 is the area south of, and including, Schofield Ledges. Subarea 3 refers to the Hadley Mountain area in the east. These subareas are delineated on Plates III, IV and V. 
Minor Folds and Foliations in Subareas 1 and 2

$\underline{F 1}$ and $\mathrm{S1}$. Minor folds of FI age are scarce in the area. However, at several outcrops (Plate II, Loc. 49, 50) the hinges of isoclinally folded quartz veins, lying in the $\mathrm{S} 1 \mathrm{plane}$ and deformed by F2 folds, are present.

S1 is a finely spaced cleavage present throughout the area. This cleavage is parallel to epidote layers and other compositional banding in the greenstone (bgs), and the fine grained gneiss (wgn). The cleavage is present in the schistose layers of the albite gneiss (agn) and is parallel to the compositional banding. In the gray and rusty schist ( $r s$ ) and the sericite schist (ss) this early cleavage is a finely spaced cleavage which is truncated by the compositional layering and the dominant'schistosity (S2). Compositional layering, and an amphibole lineation with an associated faint foliation are the earliest recognized foliations in the coarse grained amphibolite and fine grained amphibolite. Thus, the morphology of S1 varies with rock type (Fig. 7)

$\mathrm{F} 1$ and $\mathrm{S} 1$ are overprinted by $\mathrm{F} 2$ isoclinal folds. The orientation of S1 is, therefore, variable, and nearly parallel to S2. Some variation in orientation may also be due to the variety of different rock types. The orientations of the SI foliation, where distinctly separable from S2, are plotted on Plate III.

The poles to the SI foliation are plotted on lower hemisphere equal-area projections in Figures 8 and 9 . In subarea 1 there is considerable point scatter, although a best-fit girdle is approximated and oriented N21E, 77SW (Fig. 8). In subarea 2, the poles are dis- 


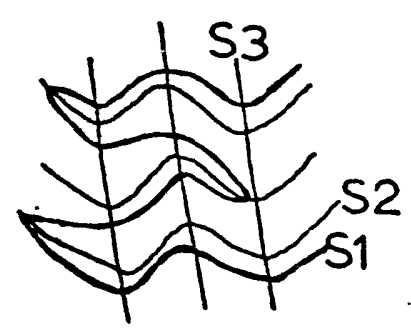

A

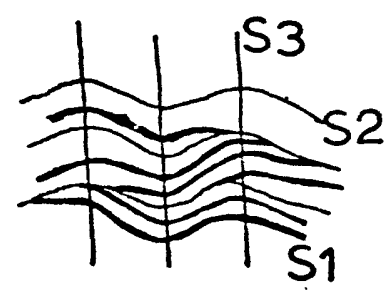

B

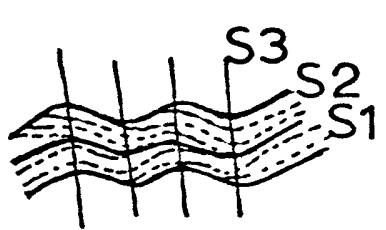

C

Cleavage in the rusty schist ( $\mathrm{rs}$ ). S1 is parallel to the compositional layers in A and B. S2 is parallel to the compositional layers in $C$.

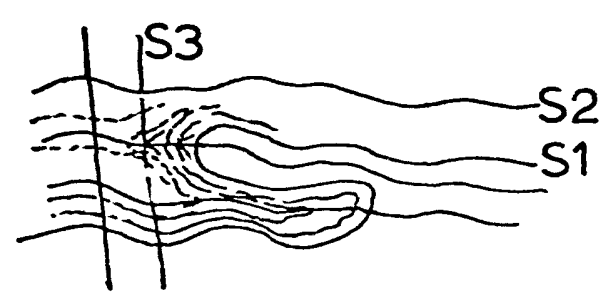

Cleavage in the albite gneiss (agn). S1 is parallel to the compositional layers, and is defined by muscovite in the phyllitic layers.

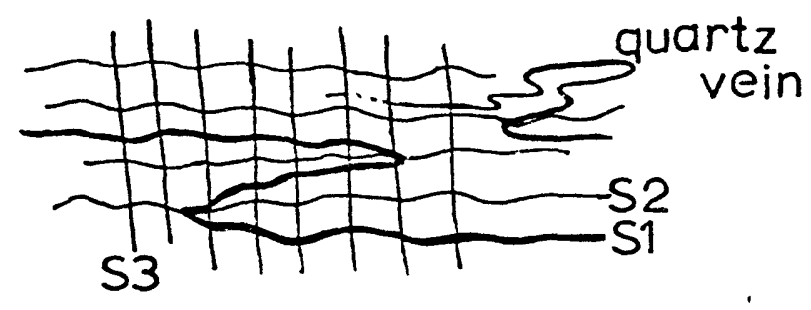

Cleavage in the greenstone (bgs). S1 is paralle1 to the compositional layers, and paralle1 to $S 2$ on the limbs of F2 folds. Quartz vein is folded by $F 1$ and $F 2$.

Figure 7. Sketch of cleavage relationships in some of the rocks of the Belvidere Mountain area. Not drawn to scale. 


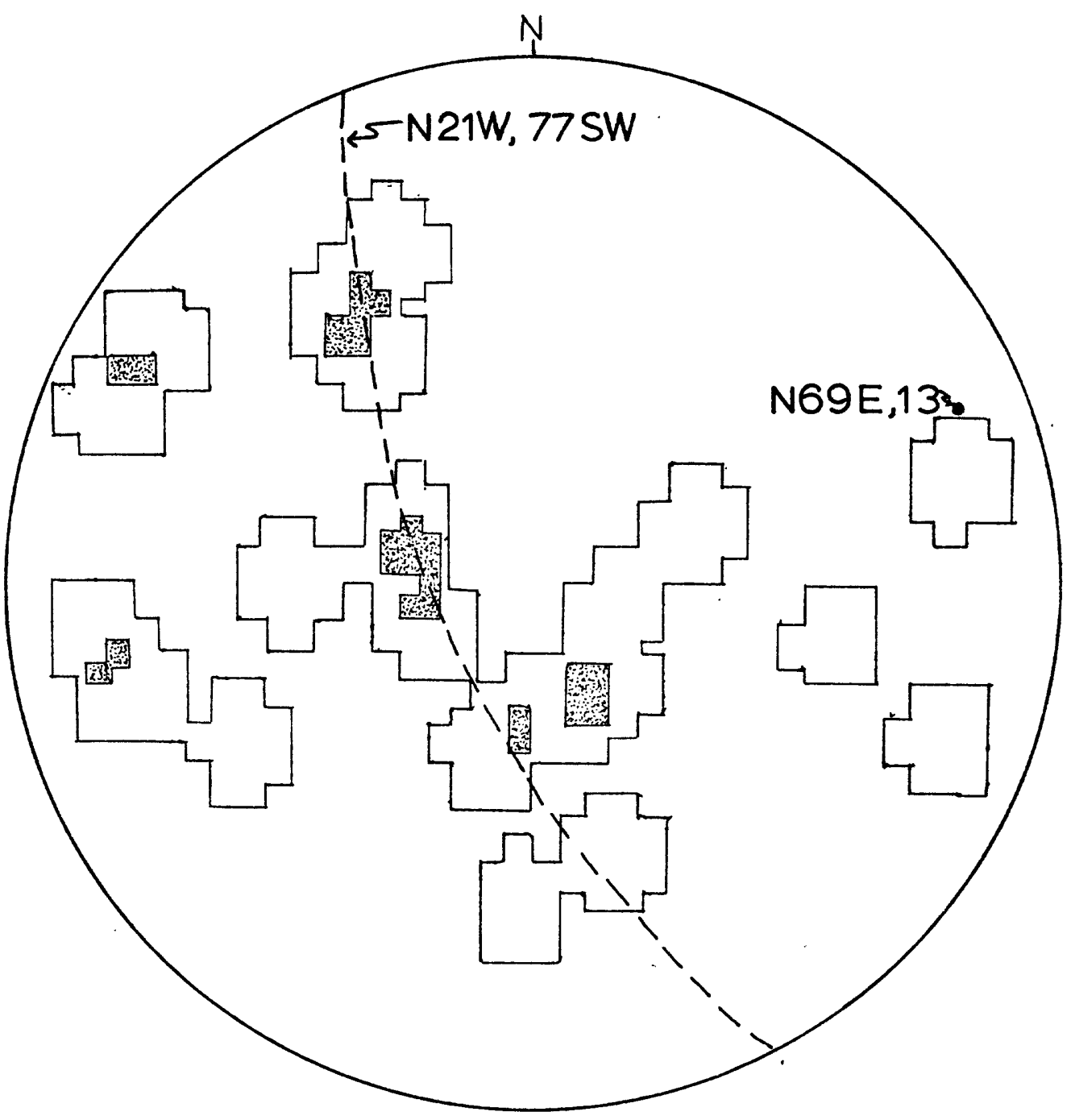

Figure 8. Lower hemisphere equal-area projection of 22 poles to the S1 foliation in subarea 1. Plane of projection is horizontal. Contour intervals are $4.5 \%$ and $9.09 \%$ per one percent area. Dashed line indicates possible great circle girdle, and the corresponding $\mathrm{Pi}$-pole is given. 
tributed along a great circle oriented N12E, 20NW (Fig. 9). The poles to these great circles 1 ie very close to the statistical axial plane of F2.

F2 and S2. F2 minor folds are present throughout the area. These folds are isoclinal to tight, and plunge SE to SW. F2 folds are superposed on the early S1 foliation and F1 minor folds. An axial surface foliation, S2, is associated with the F2 folds. Due to the isoclinal nature of $F 2, S 2$ and $S 1$ are nearly parallel except at F2 fold hinges (Fig. 10). The orientations of the S2 foliation are plotted on Plate IV. In many cases this data also reflects the orientation of S1. Stanley (pers. comm.), working to the north, has found that the prominent intersection lineation of $\mathrm{S} 1$ and $\mathrm{S} 2$ does not fold an earlier lineation, and thus he considers F1 and F2 to be coaxial. However, in the Belvidere Mountain area the amphibole lineation in the two amphibolites is deformed by $\mathrm{S} 2$, and F1 and F2 are not considered coaxial.

S2 is the dominant spaced schistosity in the area, spaced 1-2 $\mathrm{mm}$ apart. However, $\mathrm{S} 2$ is poorly developed in the epidote rich layers (parallel S1) of the greenstone and in the coarse grained amphibolite. S2 is absent in the quartzo-feldspathic layers of the albite gneiss. In the rusty schist, $\mathrm{S} 2$ is a closely spaced $(<1 \mathrm{~mm})$ slip cleavage and produces transposed layering.

The poles to the $\mathrm{S} 2$ schistosity are plotted on lower hemisphere equal-area projections in Figures 11 and 12 . In each case, the contoured poles to S2 define point maxima. However, considerable point scatter is obvious, and results from the overprint of F3 and F4 folds. The surface defined by the point maxima varies from N13E, 


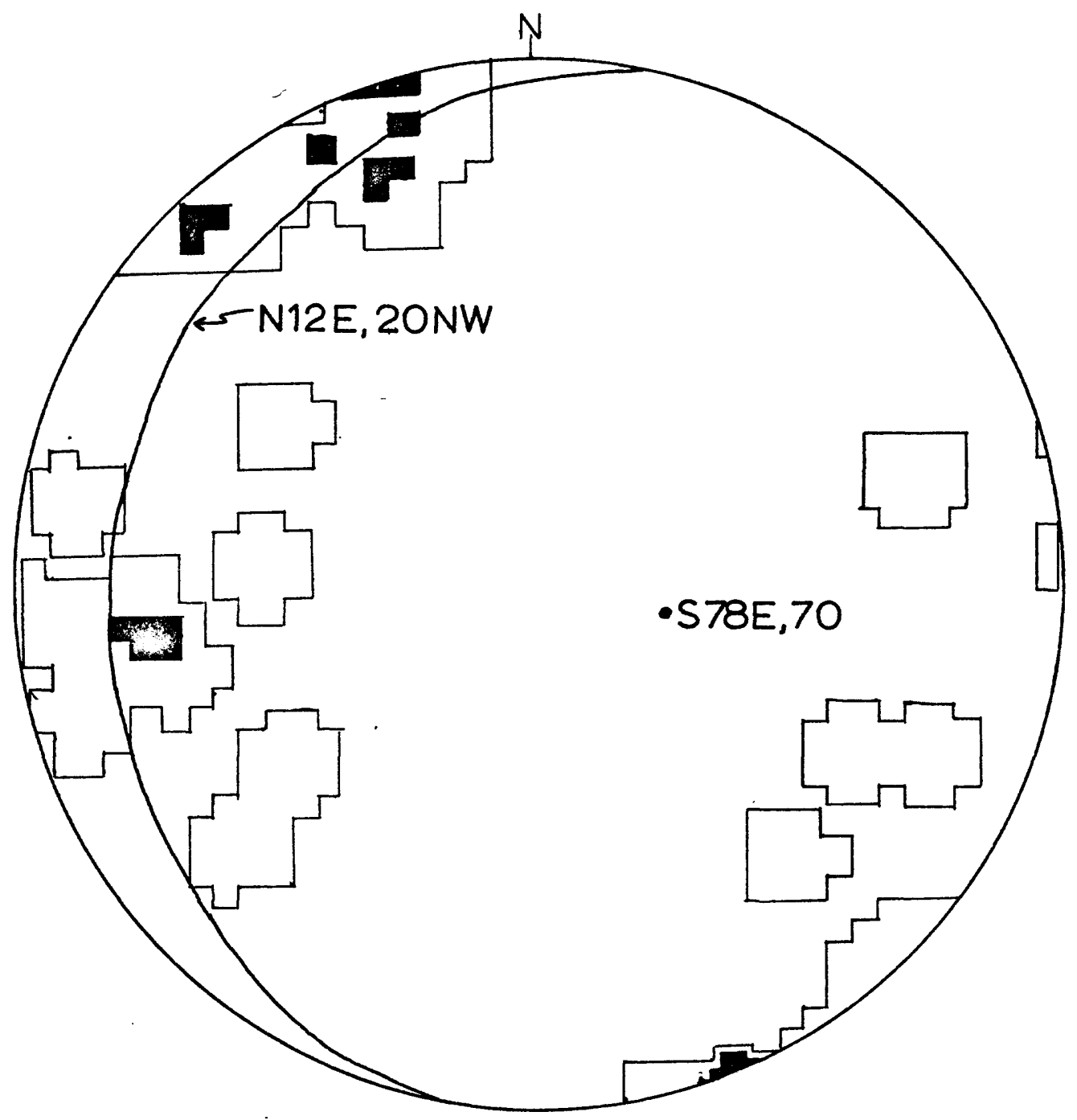

Figure 9. Lower hemisphere equal-area projection of 23 poles to the S1 foliation in subarea 2. P1ane of projection is horizontal. Contour intervals are $4.4 \%$ and $13.1 \%$ per one percent area. Great circle girdle and corresponding Pi-pole are indicated. 


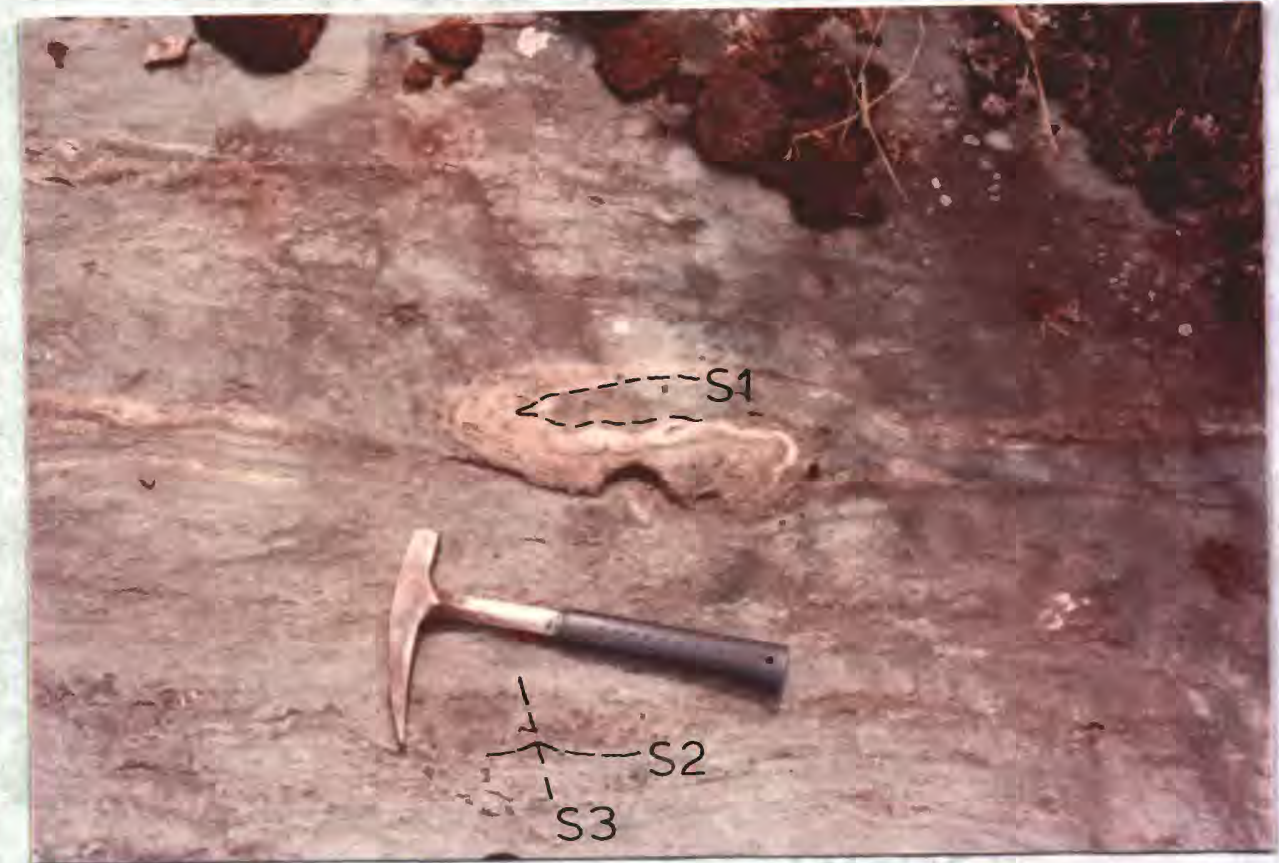

Figure 10. F2 isoclinal fold of $\mathrm{S} 1$ compositional bands in the greenstone. Location 207 on Plate II. 
84SE in subarea 2 (Fig. 11) to N11E, 45SE in subarea 1 (Fig. 12). The contoured data may actually define a broad east-west girdle, as indicated in Figure 12 by the dashed line. The change in orientation from subarea 1 to subarea 2 reflects the F3 and F4 folding on a larger scale.

The intersection lineations of S1 and S2, plus F2 fold axes, are plotted on a lower hemisphere equal-area projection in Figure 13. Although the data base is limited (38 points), the lineations define a diffuse great circle girdle nearly parallel to the S2 plane (Fig. 11, 12). This lineation distribution may result from F2 slip folding or from subsequent deformation.

F3 and S3. F3 minor folds are tight to open folds which deform both of the earlier folds and foliations. An axial surface foliation, S3, occurs throughout the area. $\mathrm{S} 3$ is a crenulate cleavage, but is sparsely developed in some of the massive rocks. The orientation of S3 varies slightly throughout the area (Plate V). In some outcrops, S3 is gently warped.

The poles to the $S 3$ foliation are plotted on lower hemisphere equal-area projections in Figures 14 and 15. In subarea 1 (Fig. 14) two solutions to the data are possible: the point maxima locates a surface oriented N1OE, 90; the great circle girdle is oriented N82W, $50 \mathrm{~W}$ with the corresponding $\mathrm{Pi}-$ pole oriented N10E, 40. Thus, the N1OE, 90 orientation defines the axial surface of S3/F3, and the Pipole locates a possible F4 fold axis. In subarea 2, the point maxima locates a plane oriented N22E, 70NW (Fig. 15).

The lineation resulting from the intersection of S2 and S3, plus the F3 fold axes, are plotted on a lower hemisphere equal-area 


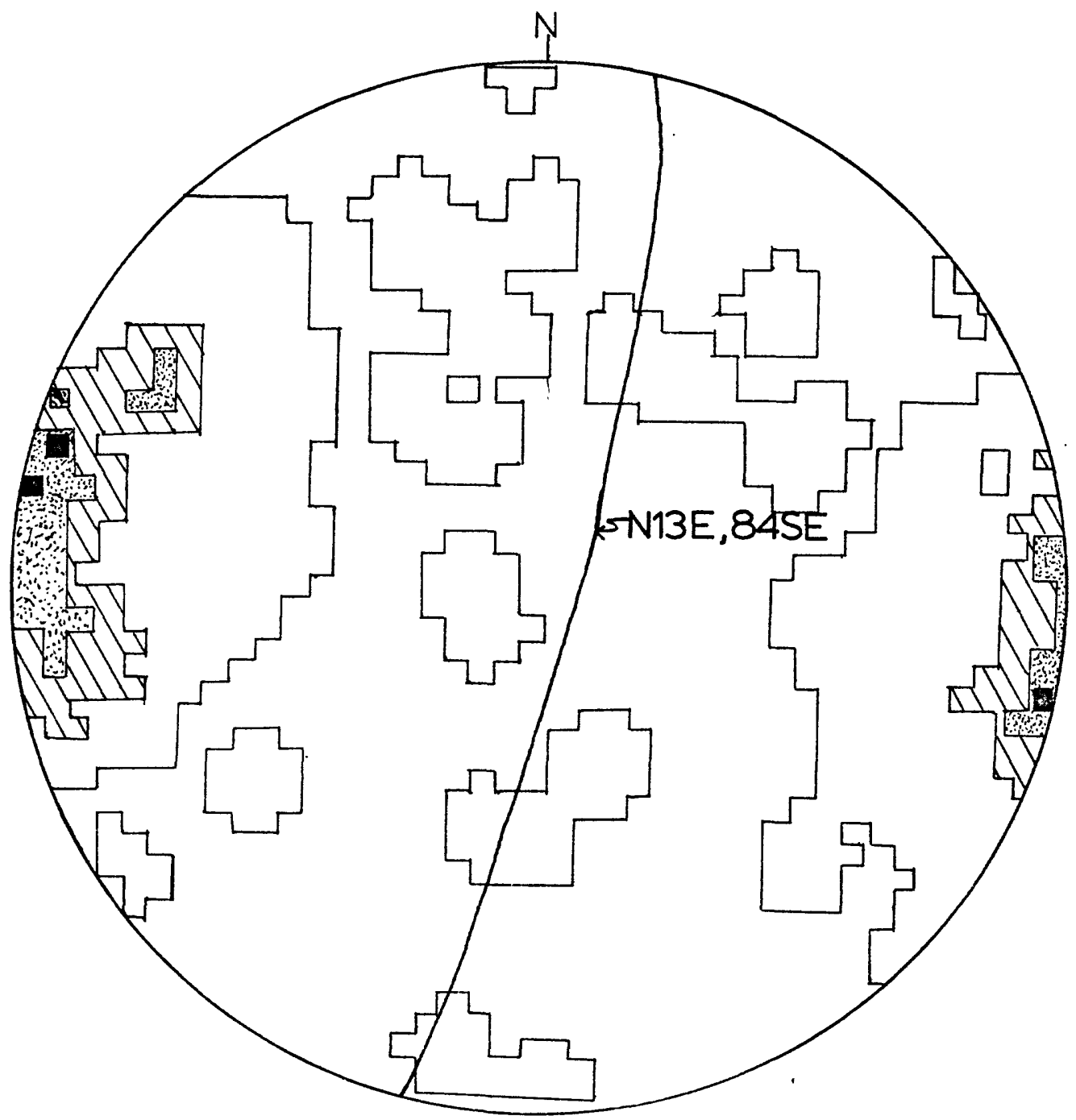

Figure 11. Lower hemisphere equal-area projection of 166 poles to the S2 foliation in subarea 2. P1ane of projection is horizontal. Contour intervals are $0.6 \%, 4.2 \%, 7.8 \%$, and $11.4 \%$ per one percent area. Solid line is the surface located by the point maximum. 


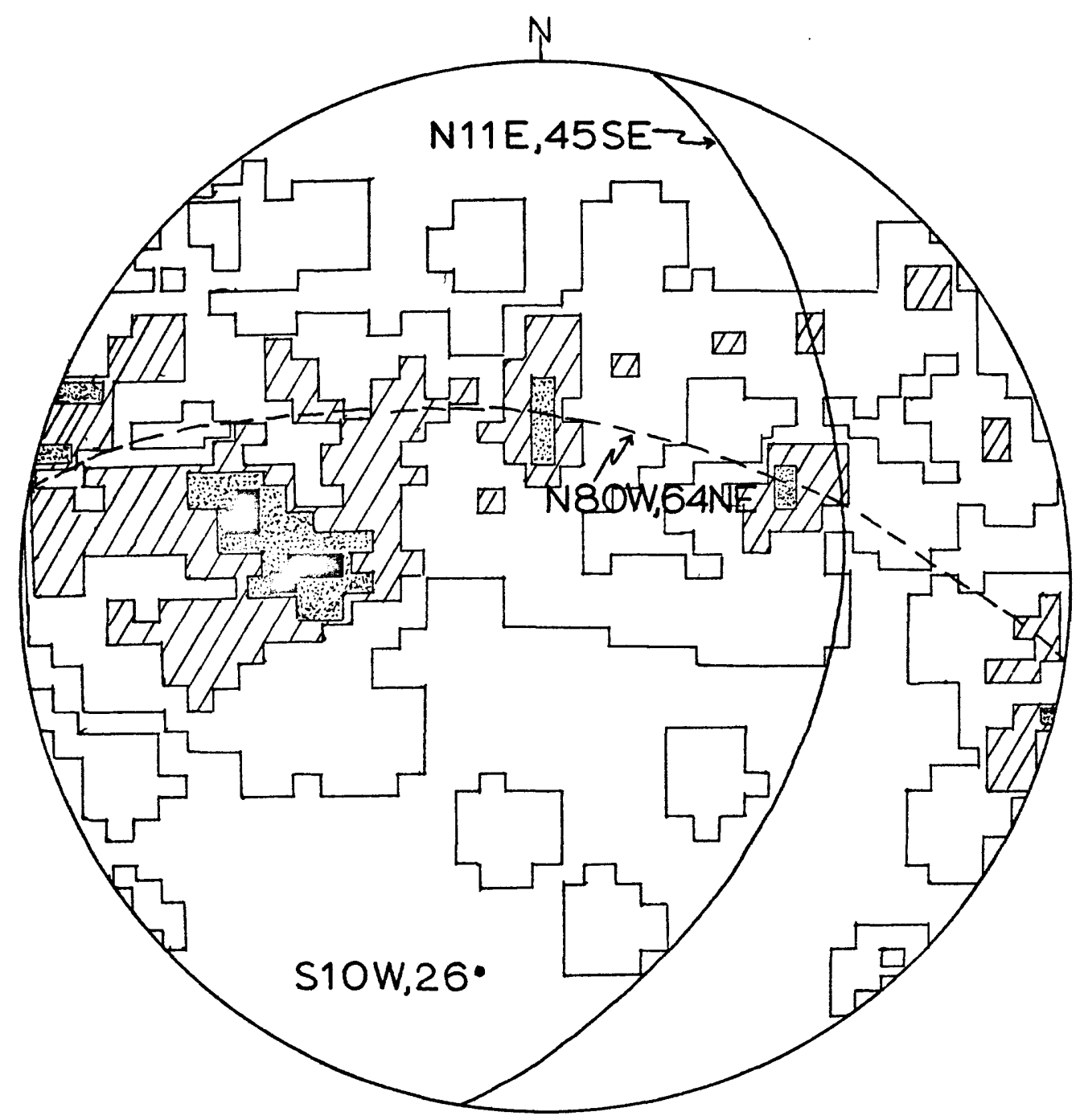

Figure 12. Lower hemisphere equal-area projection of 102 poles to the S2 foliation in subarea 1. Plane of projection is horizontal. Contour intervals are $0.98 \%, 2.94 \%, 4.9 \%$, and $6.86 \%$ per one percent area. Solid line is the surface located by the point maximum. Dashed line is the possible great circle girdle and the corresponding Pi-pole is located. 


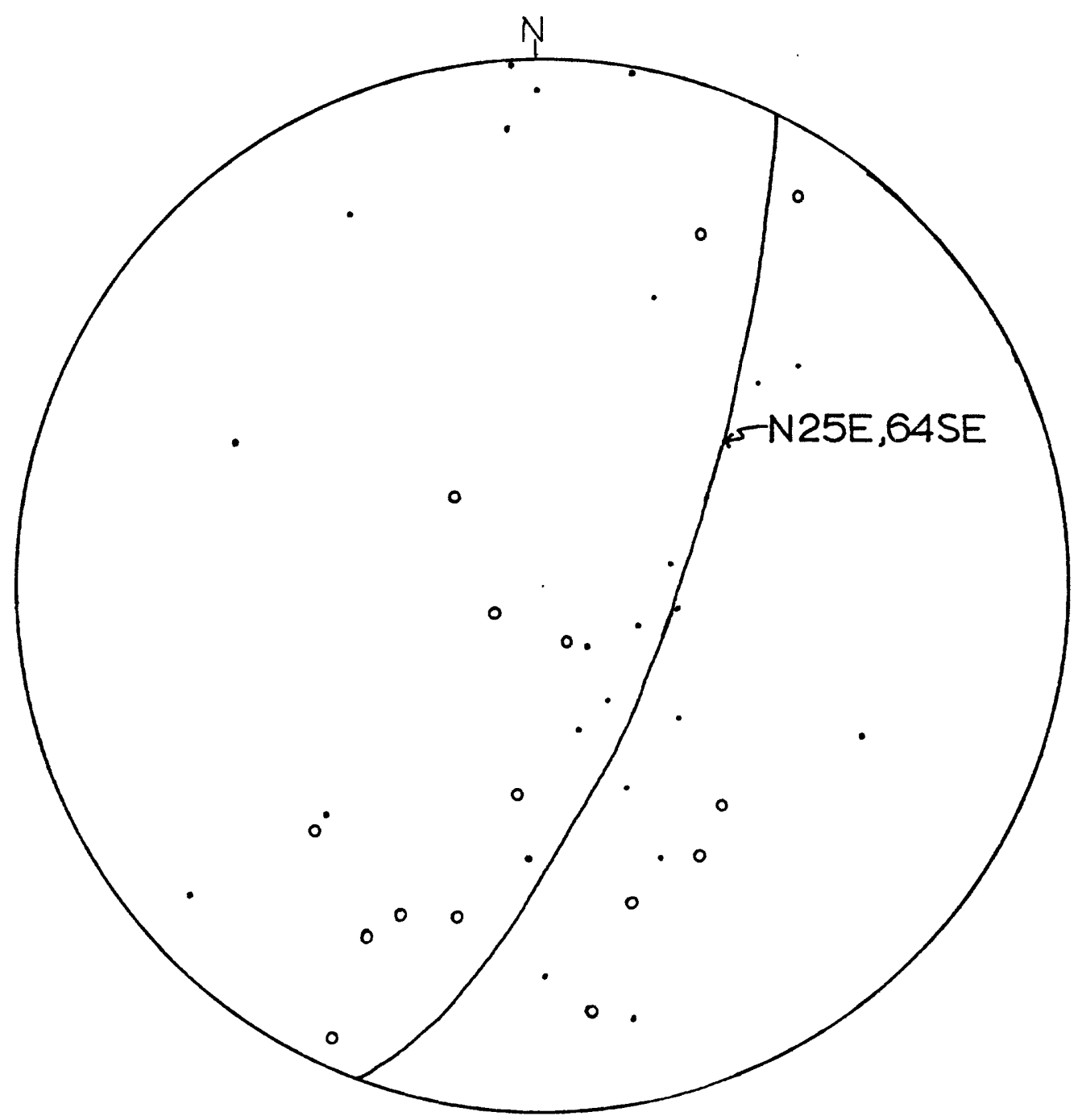

Figure 13. Lower hemisphere equal-area projection of $38 \mathrm{~S} 1-\mathrm{S} 2$ intersection lineations $(\cdot)$ and $F 2$ fold axes (0). Plane of projection is horizontal. 


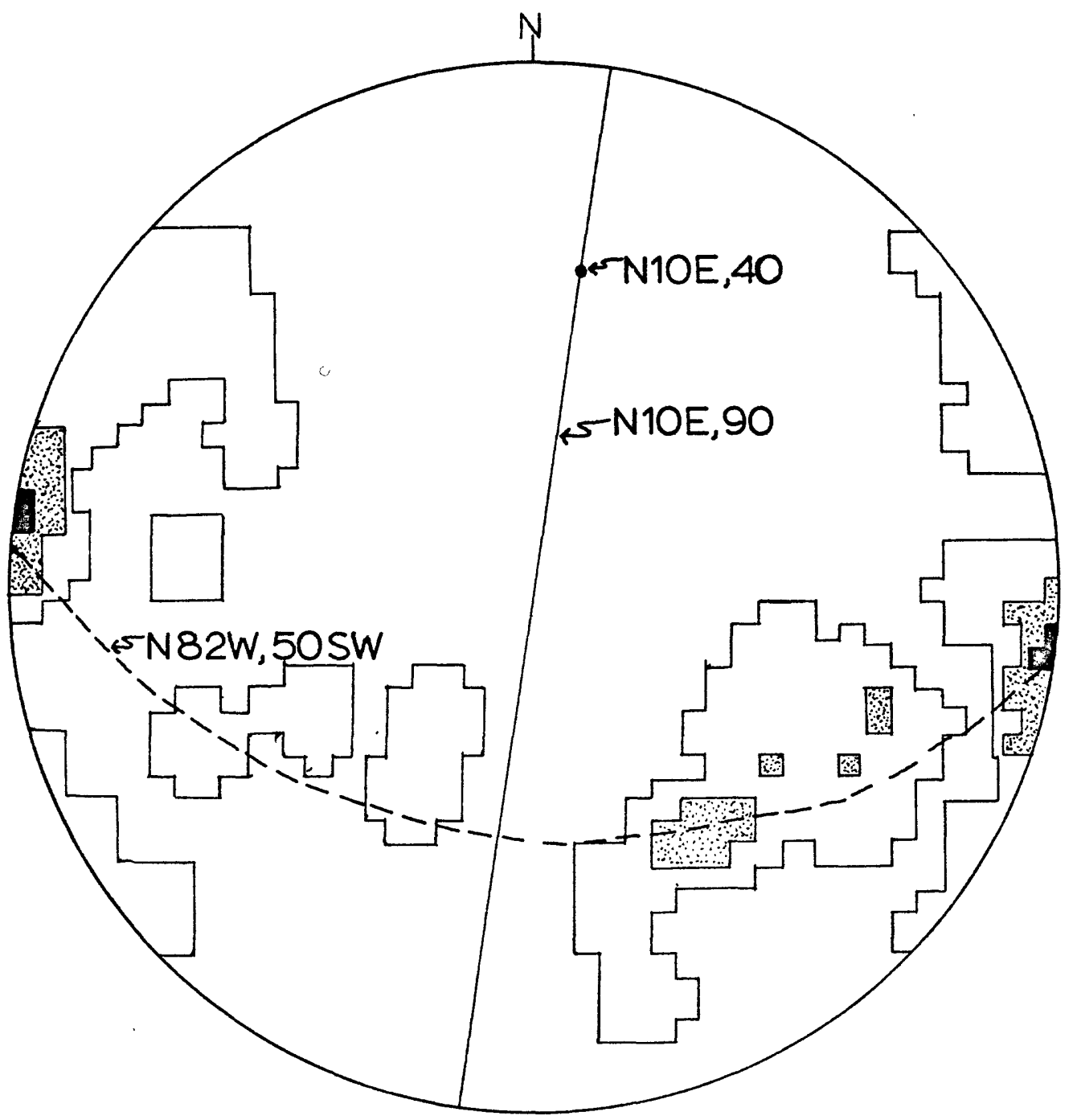

Figure 14. Lower hemisphere equal-area projection of 38 poles to the S3 foliation in subarea 1. Plane of projection is horizonta1. Contour intervals are $2.63 \%, 7.89 \%$, and $13.15 \%$ per one percent area. Solid line is the surface located by the point maximum. Dashed line is the alternative great circle girdle, and the Pi-pole is located. 


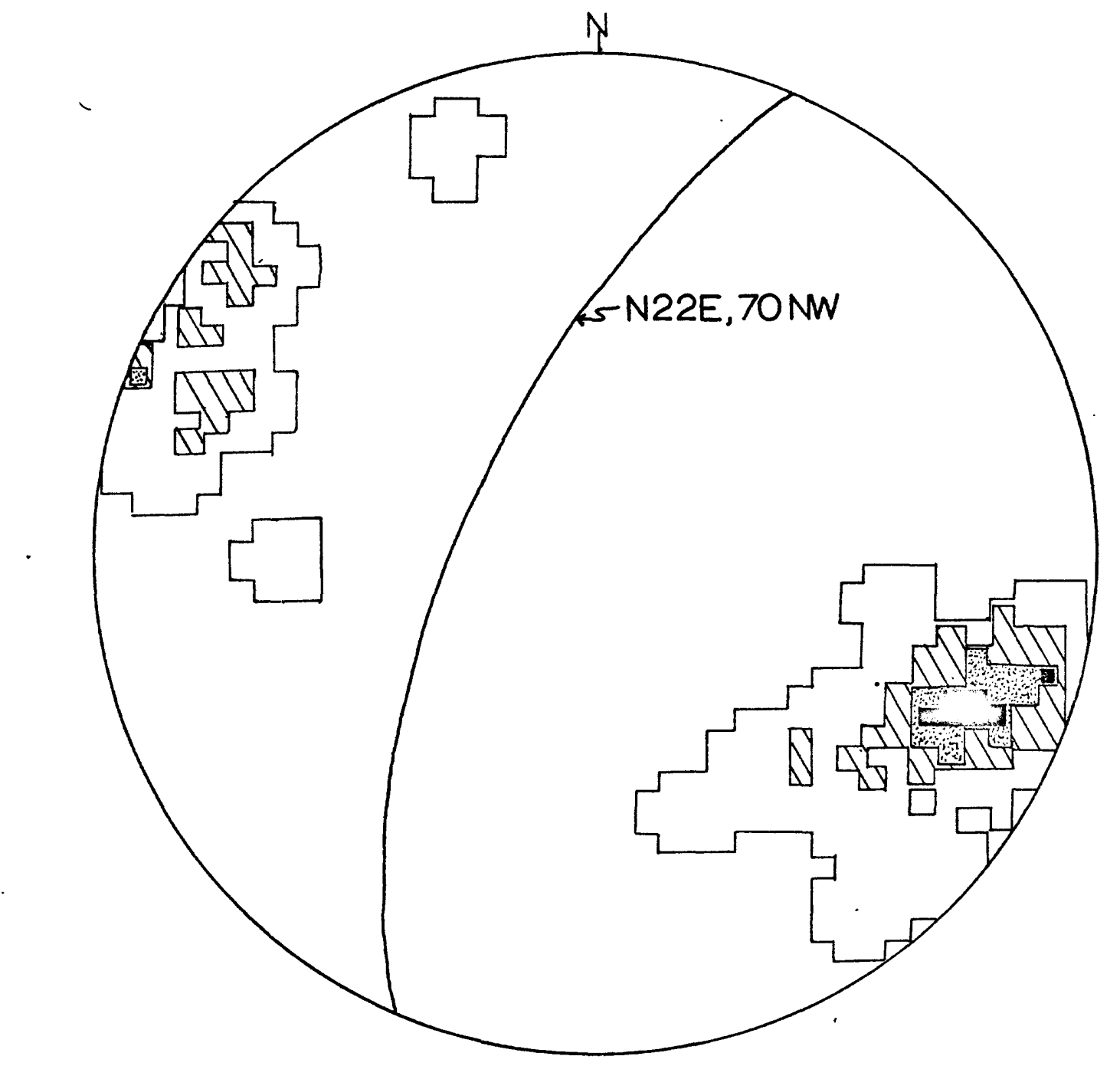

Figure 15. Lower hemisphere equal-area projection of 55 poles to the S3 foliation in subarea 2. Plane of projection is horizontal. Contour intervals are $1.82 \%, 7.27 \%, 12.73 \%$, and $18.18 \%$ per one percent area. Solid line is the surface located by the point maximum. 
projection in Figure 16. The lineations are distributed along a broad northeast girdle.

F4. A fourth fold generation is visible in outcrop by the gentle warping of the $\mathrm{S3}$ crenulate foliation. This relationship is further exemplified by considering the variation in the S3 orientation throughout the area (Plate V). Figures 14 and 15 depict the variation in orientation of S3 in subareas 1 and 2 (i.e., N10E, 90 to N22E, 70NW), and Figure 14 locates an F4 fold axis oriented N10E, 40.

No minor folds of the F4 generation were measured as the folds are very gentle and open. There is no foliation associated with F4 folds.

Major Folds in Subareas 1 and 2

The relationships observed in the minor structures are further exemplified by the map pattern (Plate I). North-northeast trending, tight to isoclinal folds of F2 age dominate the map pattern. F3 folds strike northeast and dip fairly steeply to the northwest. Both F3 and F4 folds are illustrated by the gentle folding of the F2 structures. The effect of F3 folds is particularly obvious along the western contact of the greenstone where the contact swings from northeast in the south to northwest near the summit of Belvidere Mountain, although this effect is partially due to topography.

Fl folds are difficult to delineate. The F1 structures appear to be tight, overturned folds with an east-northeast striking. axial surface. Fl structures may include the fold hinge in the lower quarry at the northern contact of the serpentinite (F1 syncline), the fold hinge in the serpentinite northwest of the summit of Belvidere 


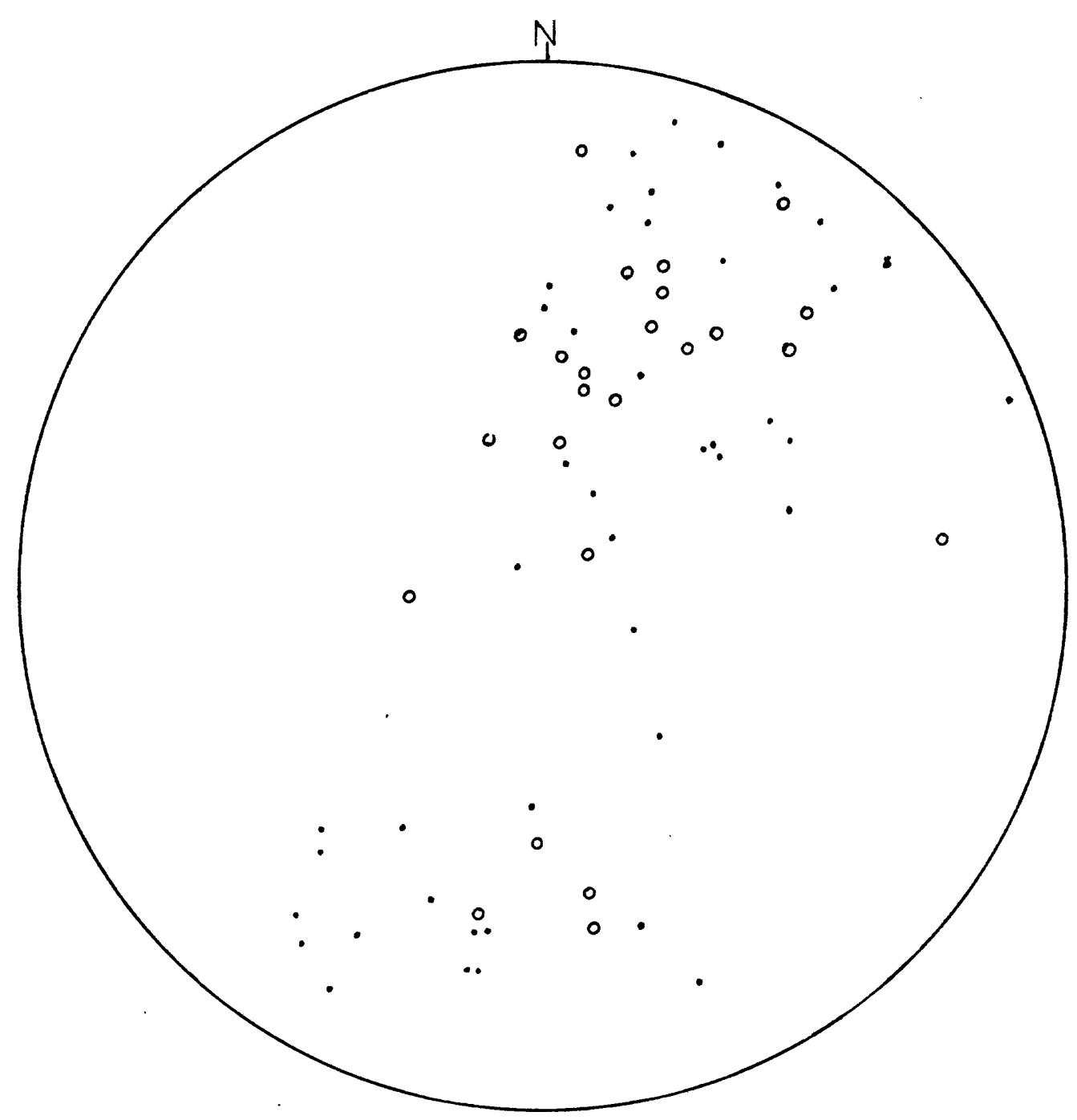

Figure 16. Lower hemisphere equal-area projection of 66 S2-S3 intersection lineations $(\cdot)$ and $F 3$ fold axes (o). Plane of projection is horizontal. 
Mountain (F1 syncline), the southern fold closure of the muscovite schist (F1 anticline), and the lithic hook in the narrow, western exposure of the greenstone (F2 syncline). The southern area, dominated by F2 folds, may represent a shallow dipping limb of the early F1 folds.

Thus, the western side of the study area reflects four fold events: F1, F2, F3, F4, F2 folds dominate the area and tend to mask the F1 structures. Fl axial surface foliations are rotated into parallelism with the F2 foliations, except at F2 fold hinges. F3 is superposed upon the earlier structures, and is responsible for the open northeast folds. F4 is visible in the gentle warping of all earlier structures.

Faults in Subareas 1 and 2

Several fault surfaces are exposed on the southwestern slopes of Belvidere Mountain. The faults are deformed by the subsequent F2, F3, and F4 fold events. The timing relationship of the faults to F1 is not completely clear. The fault surfaces represent a series of fault slivers incorporated along the base of a major thrust fault. This structural interpretation is more fully discussed at the end of the chapter.

The faults are delineated by truncation of units along a common surface, and by recognition of fault surfaces in the field. The truncation of units is indicated on Plate $I$ and in the cross-sections (Plate I). The field criteria for recognition of the fault surfaces are discussed below, with reference to the locations shown on Figure 17 . 


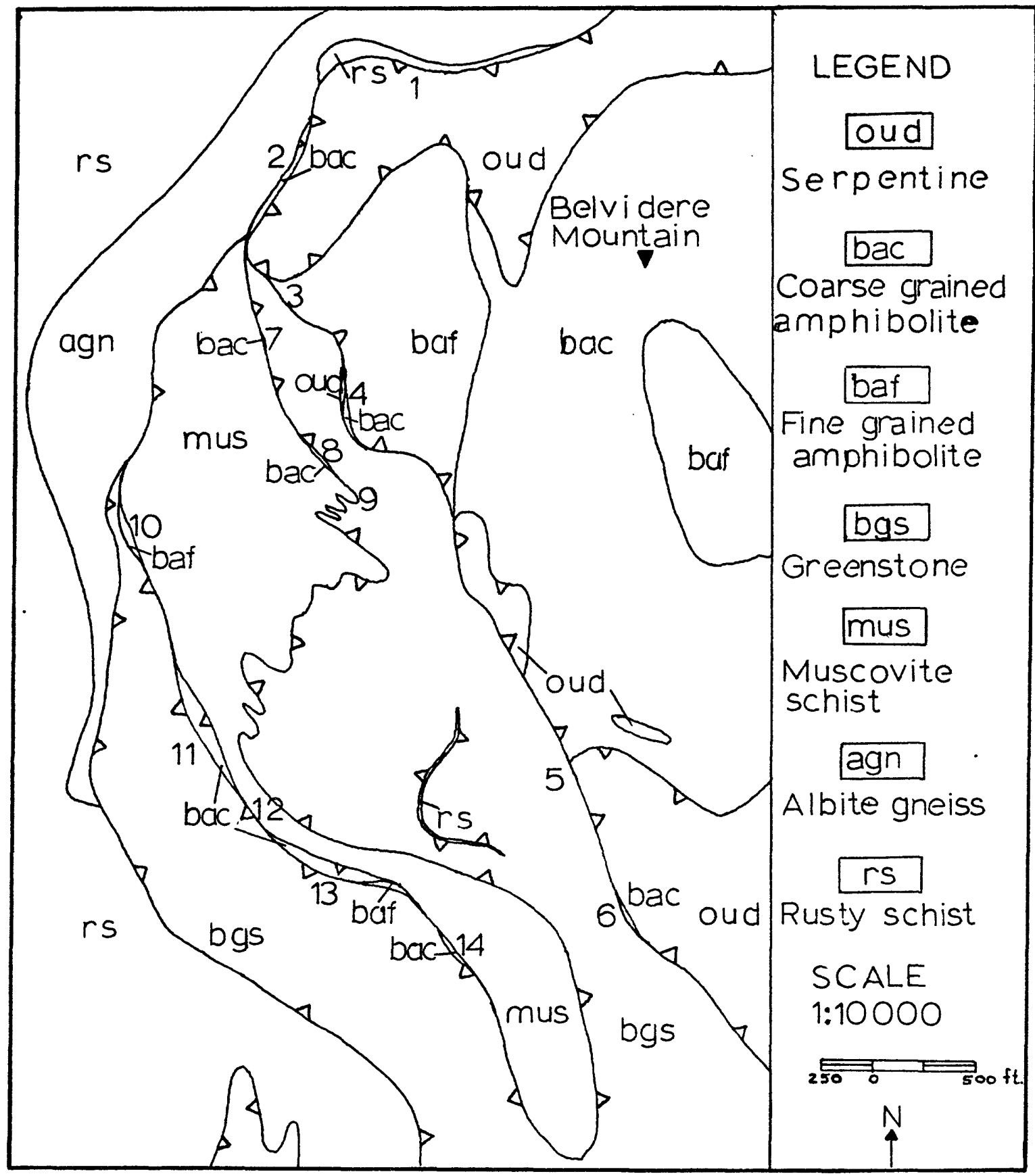

Figure 17. The summit area of Belvidere Mountain at a scale of 1:10000. Numbers 1-14 refer to locations discussed in the text. 
Locations 1-6, Figure 17. At location 1, serpentinite which weathers to a white color with black magnetite (?) smears is in fault contact with the rusty schist ( $r s$ ). The fault is oriented N65E, 65SE. The contact is marked by slickensided surfaces, and a thin layer of fine grained, almost glassy, dark gray and green banded phyllite which separates the serpentinite from the rusty schist. The compositional banding in the phyllite varies from N58E, 72SE to N80E, 51SE. Further west along this contact, the serpentinite-rusty schist contact is marked by a 0.3 meter (one foot) wide talc zone. The dominant foliation in the rusty schist is oriented N80E, 56SE.

Two outcrops of coarse grained amphibolite are present at the contact of the serpentinite and the albite gneiss at location 2 .

At location 3, the blue-gray, fine grained amphibolite displays a wel1-developed foliation which "wraps" around coarse grained, dark green actinolite-chlorite pods (Figs. 6, 18). These pods occur as rounded blocks which are easily removed from the outcrop. This outcrop is separated from the serpentinite by approximately 3 meters (10 feet) of surficial cover. Thus, the exact contact is not visible. Just southwest of location 3, brown-weathering schistose, albitic greenstone is present. $S 1$ is the dominant foliation in the greenstone and amphibolite, and varies from N30W, 70SW to N12E, 77NW. S2 varies in orientation from N03W, 65SW to N35W, 82SW, and S3 is oriented N55E, $45 \mathrm{~N}$.

At location 4, a fault contact between the fine grained amphibolite and the greenstone is exposed for about 15 meters (fifty feet) parallel the strike of the contact. The fault is oriented NS to N20W, dipping 70NW. Near the contact, the amphibolite is very fine grained, 


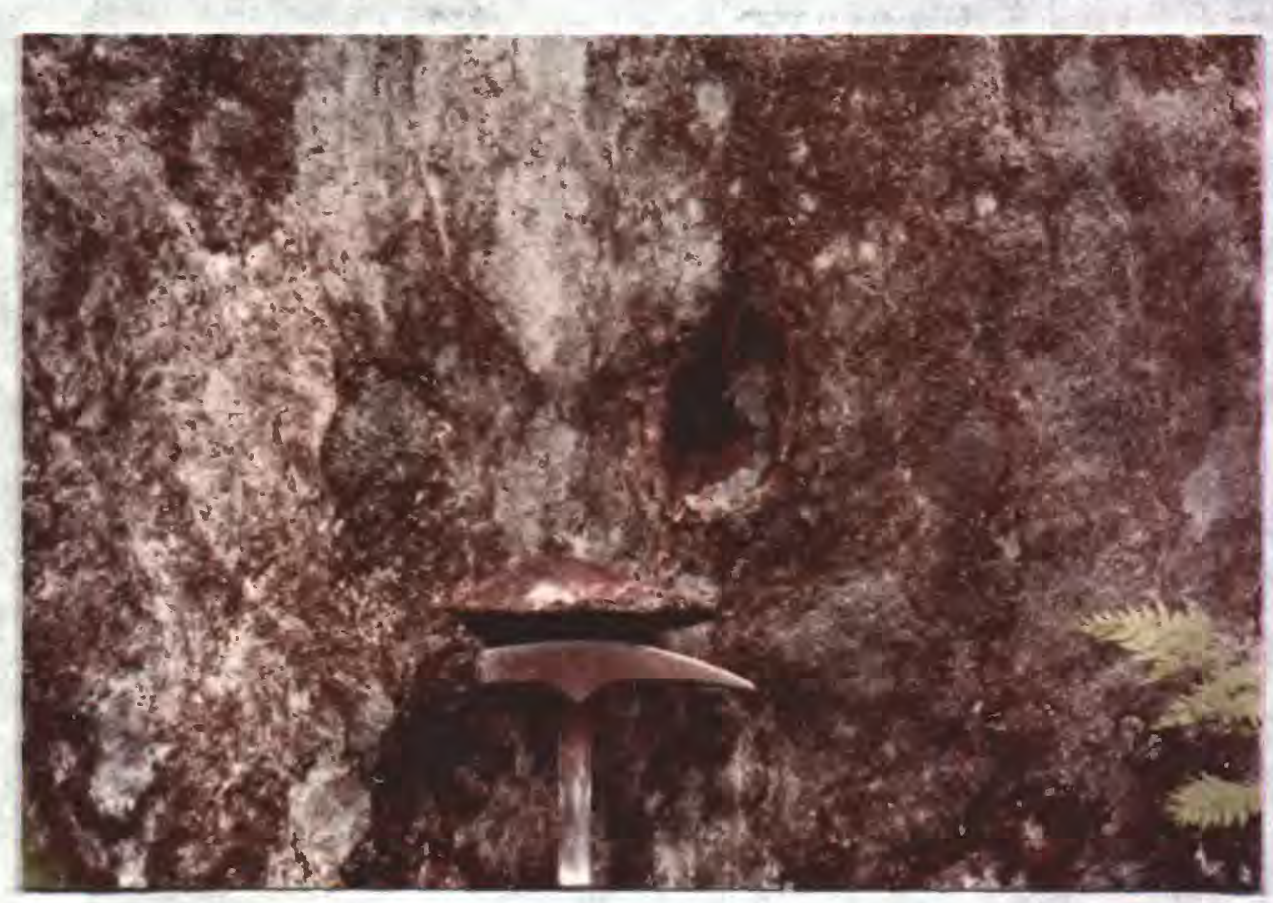

Figure 18. Actinolite-chlorite pods in the fine grained amphibolite at the serpentinite-fine grained amphibolite contact (Loc. 3, Fig. 17). 
schistose, and garnetiferous. The contact is marked by schistose serpentinite, a $1 \mathrm{~m}$ ( $3 \mathrm{ft}$. ) wide layer of rusty schist, a talc zone, and a thin sliver of coarse grained amphibolite. The contact of the amphibolite with the serpentinite is also marked by round, extremely coarse grained, actinolite-chlorite rock pods within the amphibolite. These pods are identical to those at location 3 . Just to the southeast of location 4, the surface of the amphibolite is coated with a fine grained, pale green, 2 to $15 \mathrm{~mm}$ thick "sheet" of contorted talccarbonate material which contains numerous bent and broken amphibole laths 1 to $2 \mathrm{~cm}$ in 1ength. The serpentinite, the rusty schist, and the coarse grained amphibolite are all discontinuous, small slivers along the fault zone.

At location 5, sheared serpentinite is underlain by a redbrown weathering, soft, highly contorted talc zone (Fig. 19).

At location 6 , the contact between the serpentinite and the greenstone is marked by, in outward succession from the serpentinite, a zone of rusty-weathering talc-rich rock, a discontinuous layer of coarse grained amphibolite, and dark green actinolite-chlorite rock similar to that in the previously discussed actinolite-chlorite pods (Fig. 20)

Locations 7-14, greenstone-muscovite schist contact (Fig. 17). The contact between the greenstone and the muscovite schist is marked by numerous fault slivers and by talc-rich shear zones. Along the eastern contact, at location 7, a sliver of coarse grained amphibolite is present. The amphibolite differs from the main mass of amphibolite by a slightly finer grain size, and by the presence of folded, offset, discontinuous epidote-rich layers. The amphibolite is a distinctive 


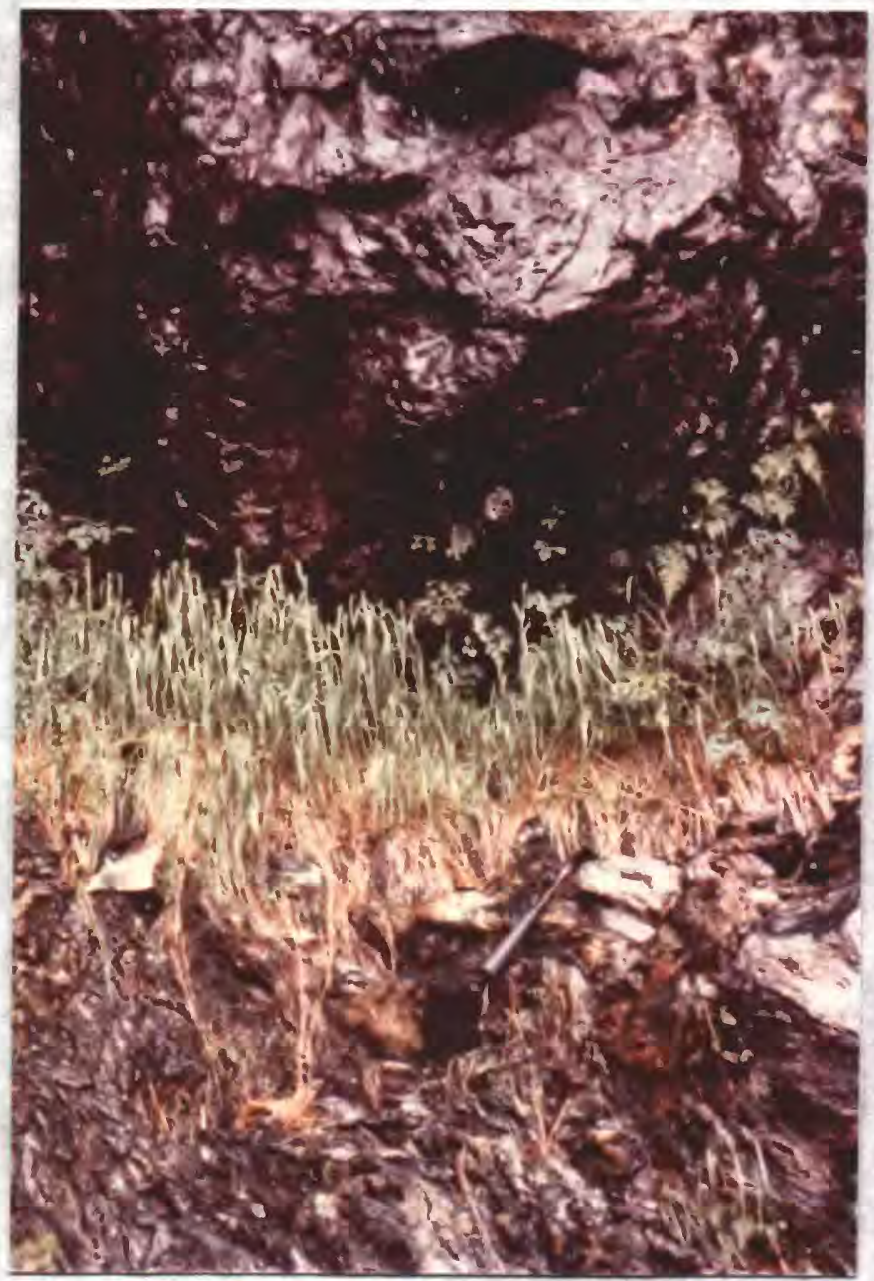

Figure 19. Serpentinite (top) and talc-rich shear zone (bottom) at the contact of the serpentinite and the greenstone (Fig. 17, Loc. 5; Plate II, Loc. 445). 


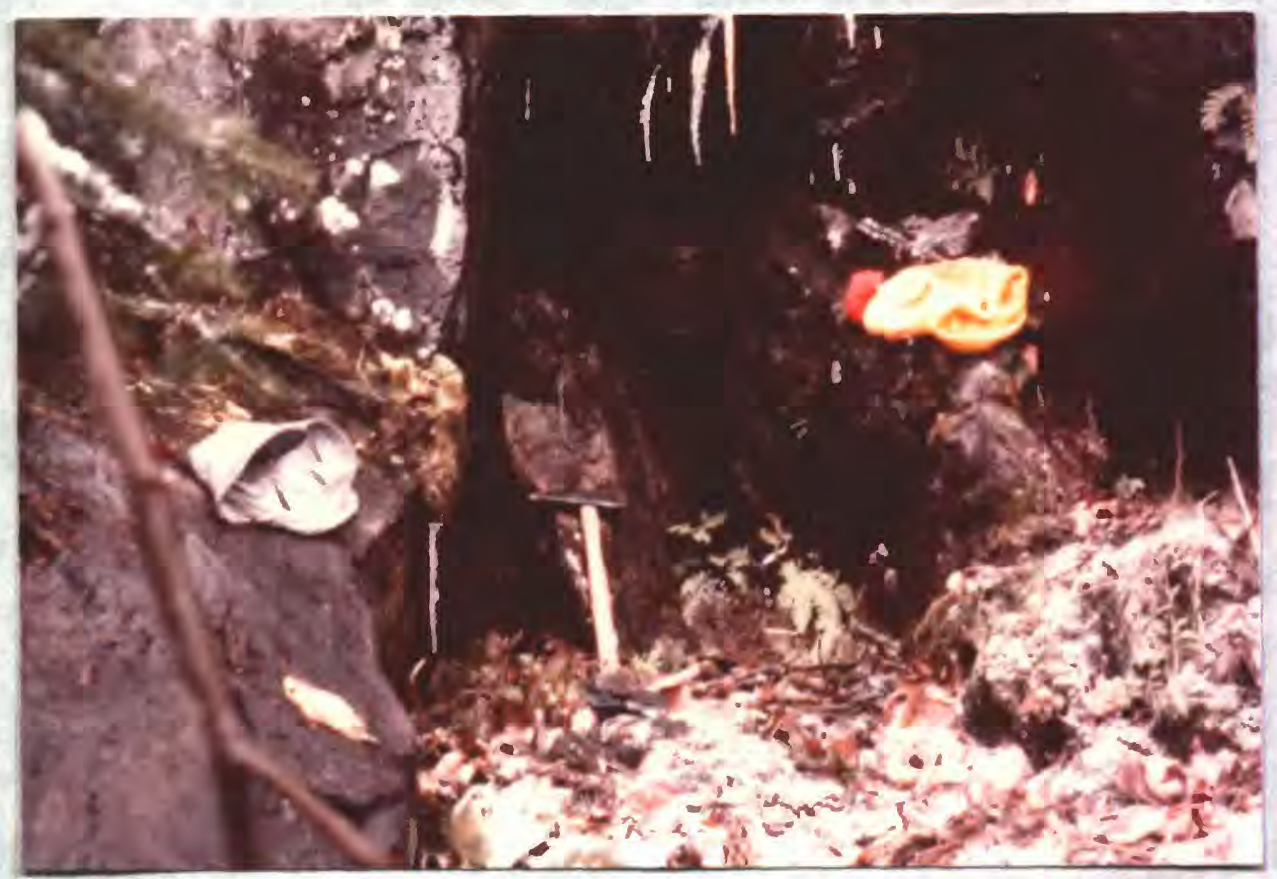

Figure 20. From left to right, coarse grained amphibolite sliver, talc zone, and serpentinite at the greenstoneserpentinite contact (Fig. 17, Loc. 6). 
black and yellow-green color. In the muscovite rock, the early S1 foliation is isoclinally folded by $F 2$. The isoclinal fold is overprinted by F3, and the F3 axis is oriented N25E, 25. The orientation of $\mathrm{S} 1$ varies from $\mathrm{EW}, 38 \mathrm{~S}$ to $\mathrm{N} 75 \mathrm{~W}, 19 \mathrm{~S}$.

Further south, at location 8 , the muscovite schist is succeeded upward by a two inch thick talc-rich layer, a one foot thick layer of magnetite-rich, chlorite-epidote-quartz rock with a contorted appearance, a one inch thick talc layer, and the dark gray, coarse grained amphibolite. The contact of the greenstone and the amphibolite is not exposed. Two foliations are visible in the greenstone. S1 is oriented N25W, 15NE, and is overprinted by S2 oriented N05E, 40NW.

At location 9, in the area of the tight folds, the contact between the muscovite rock and the greenstone contains one of the following: a thin, highly deformed, talc-rich shear zone; an extreme1y rusty-weathering talc-carbonate rock; a fine grained, almost glassy, pale green rock. A talc shear zone is also present to the southwest, just north of location 12 .

Along the western contact of the muscovite schist and the greenstone, the muscovite schist is on top of the greenstone. The contact contains several fault slivers described below.

At location 10, two outcrops of fine grained amphibolite are present. Further south, at location 11, the most graphic example of this fault occurs. The coarse grained amphibolite occurs as a large sliver between the greenstone and the muscovite rock. This area will be described from top to base. 
Near the contact, the muscovite schist is darker in color, and contains several rounded fragments of coarse grained amphibolite, greenstone, and a fine grained, white-speckled (calcite), gray metavolcanic rock. The fragments are as large as $0.3 \mathrm{~m} \mathrm{(1} \mathrm{ft.)} \mathrm{across,}$ but the contact of each fragment with the muscovite schist is diffuse and obscure. The foliation in the muscovite rock is highly variable, ranging from $\mathrm{N} 40 \mathrm{E}, 38 \mathrm{NW}$ to $\mathrm{N} 05 \mathrm{E}, 20 \mathrm{~S}$ to N50W, $54 \mathrm{SW}$.

The coarse grained amphibolite is directly beneath the muscovite schist (Fig. 17, Loc. 11), and contains some thin, discontinuous layers of the muscovite schist. In thin section, the amphibolite is muscovite bearing. Close to the lower contact of the amphibolite, the amphibolite is a distinctive black, yellow, and green rock. This change in appearance is due to the presence of discontinuous, folded, offset, epidote-rich bands within the amphibolite.

At the base of the amphibolite, a 2 meter ( $6 \mathrm{ft}$.$) section$ across the fault contact with the greenstone is exposed. A silvergray schist is immediately below the amphibolite. The foliation in the schist is approximately parallel to the fault surface. However, several tight folds are visible, and are truncated by the coarse grained amphibolite. The schist is underlain by a 0.3 meter ( $1 \mathrm{ft.}$ ) thick layer of deformed talc-rich phyllite. Albitic greenstone is at the base of the contorted talc phylite.

The fault varies in orientation from N65E, $20 \mathrm{NW}$ to N40E, $20 \mathrm{NW}$. The contact expressed by the map pattern is nearly parallel to the dip direction of the fault, and nearly parallel to the strike of the S2 schistosity (N13W, 80SW). This location is important when considering the map pattern. The map shows the contact as trending northwest, 
although the actual contact strikes northeast and has a shallow dip to the north. The apparent northwest contact is actually due to topography exposing a partial cross-section, plus the effects of the F2 and $\mathrm{F} 3$ folds.

Further southeast, in the stream bed at location 12, a layer of rusty-weathering talc-rich phyllite is exposed. The foliation is extremely variable, producing a contorted appearance in the rock. This contact is easily followed north to location 11, and the talc phyllite represents the same fault surface.

A fault sliver of coarse grained amphibolite occurs at location 13, just southeast of location 12 . Some variation in the amphibolite is noted from west to east. At the western end, the amphibolite is the distinctive black and yellow-green previously described. 65 meters (200 ft.) to the east, a thin, sheetlike covering of actinolite-chlorite rock (1ike that at locations $3,4,6$ ) occurs on the outcrop surface. Further east, dark gray amphibolite and banded amphibolite, like that at the summit of Belvidere Mountain, is exposed. The banding is oriented N65W, 80SW. Near the eastern end of the sliver, the amphibolite is finer grained, dark green in color, and contains numerous calcite veins. This variety of the amphibolite is in direct contact with the muscovite schist.

Two outcrops of fine grained amphibolite are present at the east end of the coarse grained amphibolite sliver, along the greenstone-muscovite schist contact. Further southeast, at location 14, an outcrop of the black and yellow-green amphibolite, with an irregular, contorted foliation is present. 
Thus, the contact between the greenstone and the muscovite schist contains numerous fault slivers and talc-rich shear zones. The greenstone is below the muscovite schist in the west, and above the muscovite schist in the east. In addition, the actual contact between the two units (where measured) strikes to the northeast, and has a shallow dip to the northwest. The superposition of F2 folds, plus the topography, result in a deceptive north-south contact on the map pattern.

The continuation of the faults to the south is 1argely inferred. The gneiss is shown truncated against the greenstone just east . of Schofield Ledges. No outcrop of greenstone is present east of the gneiss in this area. Thus, the gneiss could alternatively be surrounded by rusty schist (rs) at Schofield Ledges, and separated from the schist by serpentinite and talc-steatite. In either case, the relationships in the northern area are preserved, and the contact of the greenstone with the underlying metasediments (rs, agn) is a fault contact.

Several isolated talc-steatite, talc-carbonate, and quartzcarbonate rocks occur within the greenstone and along the contacts of the greenstone with the metasediments ( $r s, s s$ ) in the southern part of the field area. These occurrences are denoted by X on Plate I.

Summary and Discussion of Subareas 1 and 2

Four fold generations are recognized in the area, based on the superposition of minor folds and foliations, and correlation of these minor structures with larger folds visible in map pattern. F2, F3, and F4 all post-date the faults since the fault contacts are deformed 
by these folds on both a minor and major scale. Fl folds are synfault deformation.

The faults are recognized on the basis of truncation of units along a common surface, the presence of fault slivers along contacts, and the truncation of fold structures along a surface. These fault contacts are depicted on Plate I, and in the cross-sections (Plate I). The faults are briefly summarized below.

The contact of the serpentinite and the greenstone, the serpentinite and the albite gneiss, the greenstone and the muscovite schist, and the fine grained amphibolite and the greenstone are all marked by fault slivers of coarse grained amphibolite, fine grained amphibolite, talc, serpentinite, and/or talc-carbonate rock. These contacts are therefore fault contacts. In addition, the coarse grained amphibolite, the fine grained amphibolite, and the greenstone are truncated by the serpentinite, providing further fault evidence.

The folded (F1) fault contact of the greenstone with the muscovite schist is truncated against the albite gneiss (Fig. 17). West of Loc. 11 (Fig. 17), the albite gneiss-rusty schist contact is truncated by the greenstone. Thus, the contact of the albite gneiss and rusty schist with the greenstone, muscovite schist, and serpentinite is a fault contact which post-dates the early fold event (F1) in the ultramafic rocks and the associated amphibolites, greenstone, and muscovite schist. This contact is folded by F2. The F2 folds are particularly conspicuous along the southern continuation of the fault contact where the greenstone is juxtaposed on the rusty schist and the sericite schist (Plate I). On the southern slopes of Belvidere Mountain, the contact of the rusty schist with the over- 
lying albite gneiss is marked by two small bodies of serpentinite and talc-steatite rock (Plate I). The presence of serpentinite along this contact also suggests a fault contact between the rusty schist and the albite gneiss.

South of Schofield Ledges, the western contact of the greenstone with the rusty schist is marked by several isolated bodies of talc-carbonate rock and talc-steatite (Plate I) thus providing additional evidence for the continuation to the south of the faults delineated on Belvidere Mountain. Talc-carbonate rock is also present at the contact of the greenstone with the sericite schist. The greenstone is thus in contact with albite gneiss, rusty schist, and sericite schist along its western and southern contact. This contact is interpreted as a fault contact, and the contact is folded by F2, F3, and F4 folds. In addition, the isolated talc-carbonate and quartzcarbonate bodies within the greenstone (Plate I) most probably are at the base of the greenstone and represent the fault surface.

Minor Structures in Subarea 3

The work on Hadley Mountain is preliminary. The geology was not mapped in the same detail as that in subareas 1 and 2 . Correlating the geology on Hadley Mountain with the geology to the west is complicated by the extensive area of surficial cover, and by the limited time spent on Hadley Mountain. Thus, the area is only briefly discussed here.

Primary structures. Bedding is recognized in one outcrop of the phyllitic graywacke just west of The Knob. Bedding varies from N21E, 30NW to N10W, 82NE. The topping direction in the graded beds also varied from west to east. 
Minor folds and foliations. Two foliations are observed in the rocks. The early foliation is a finely spaced cleavage which occurs parallel to the compositional layering. The poles to this cleavage are plotted on a lower hemisphere equal-area projection in Figure 21 . The contoured poles define a point maximum which locates a plane oriented N26E, 65SE. It is a1so possible to locate a great circle girdle (dashed line) oriented N70W, 66SW. No minor folds associated with this cleavage were observed.

The early foliation is overprinted by a crenulate cleavage. In some locations, this cleavage is a slip cleavage. The crenulate cleavage occurs parallel to the axial plane of abundant tight to open folds which deform the earlier cleavage and the compositional layers. The poles to the crenulate cleavage are plotted on a lower hemisphere equal-area projection in Figure 22. The poles form a point maximum which locates a surface oriented N34E, 75NW.

\section{Correlation with Subareas 1 and 2}

The crenulate cleavage in subarea 3 most probably correlates with the crenulate foliation in subareas 1 and $2 .^{\prime}$ This conclusion is based on both similarities in orientation and style. However, S3 is more we11-developed and pervasive in the rocks on Hadley Mountain. The poles to the crenulate foliation in subareas 1,2 , and 3 are plotted on a lower hemisphere equal-area projection in Figure 23. The contoured poles locate a plane oriented N12E, 88 SE.

The early cleavage on Hadley Mountain is correlated with the S2 schistosity in subareas 1 and 2. The spaced cleavage on Hadley Mountain pre-dates the crenulate cleavage, and is similar in both style and orientation to $S 2$ in subareas 1 and 2 . The poles to the 


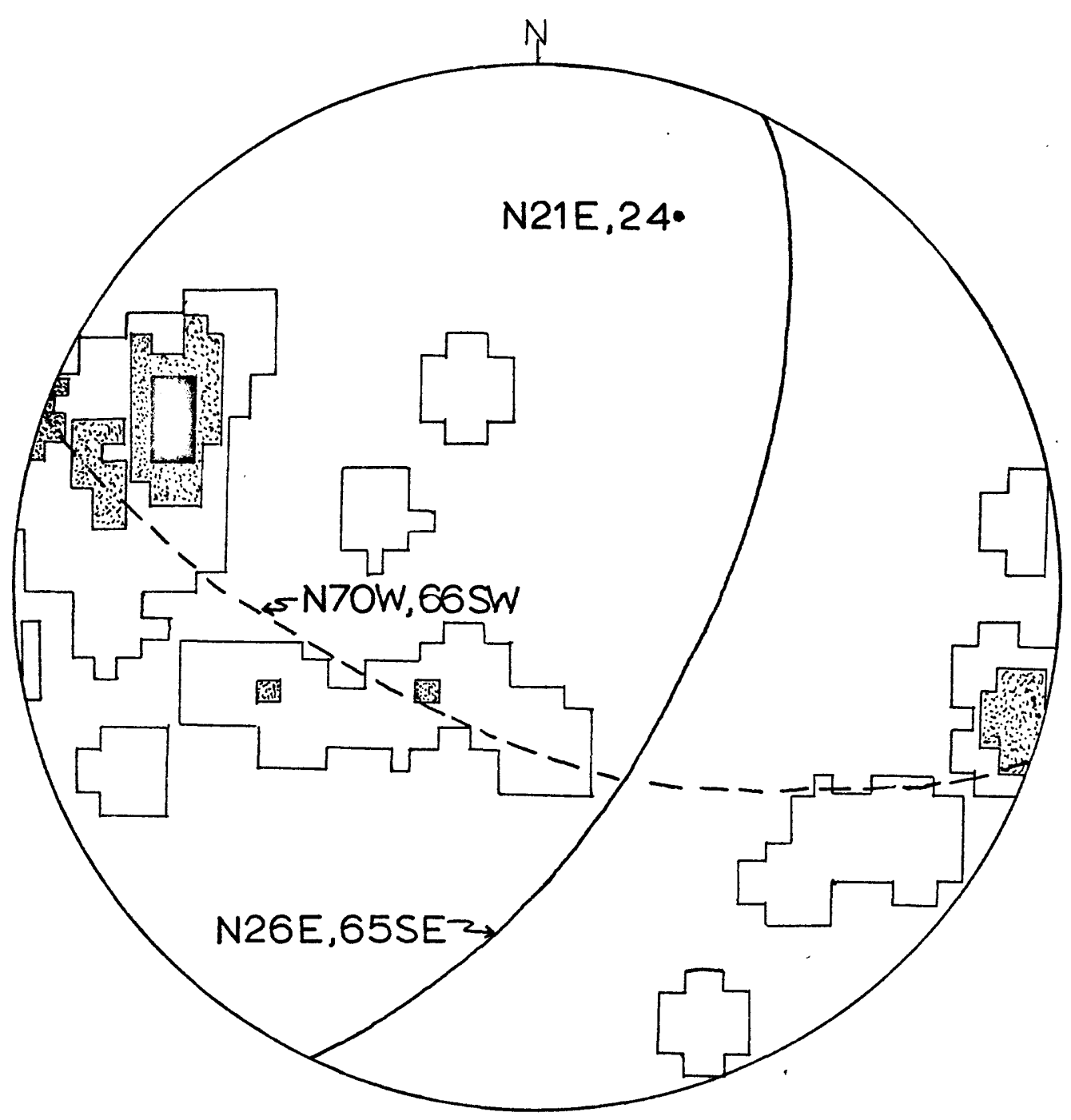

Figure 21. Lower hemisphere equal-area projection of 35 poles to the S2 foliation in subarea 3. P1ane of projection is horizontal. Contour intervals are $2.9 \%, 8.6 \%$, and $14.3 \%$ per one percent area. Solid line is the surface located by the point maximum. Dashed line represents a possible great circle girdle; the corresponding Pi-pole is indicated. 


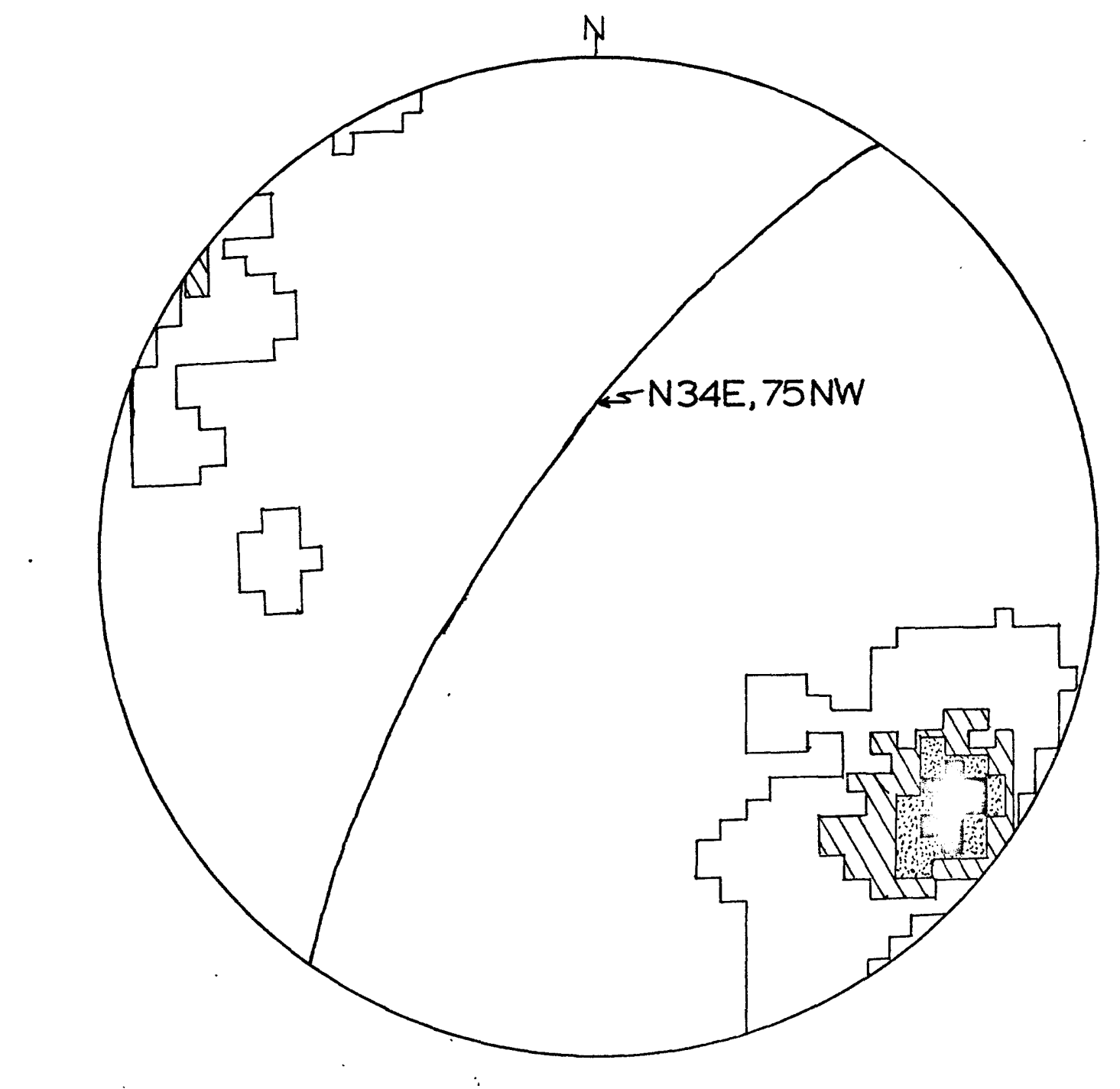

Figure 22. Lower hemisphere equal-area projection of 43 poles to the S3 foliation in subarea 3. P1ane of projection is horizontal. Contour intervals are $2.3 \%, 9.3 \%, 16.3 \%$, and $23.3 \%$ per one percent area. Solid line is the surface located by the point maximum. 


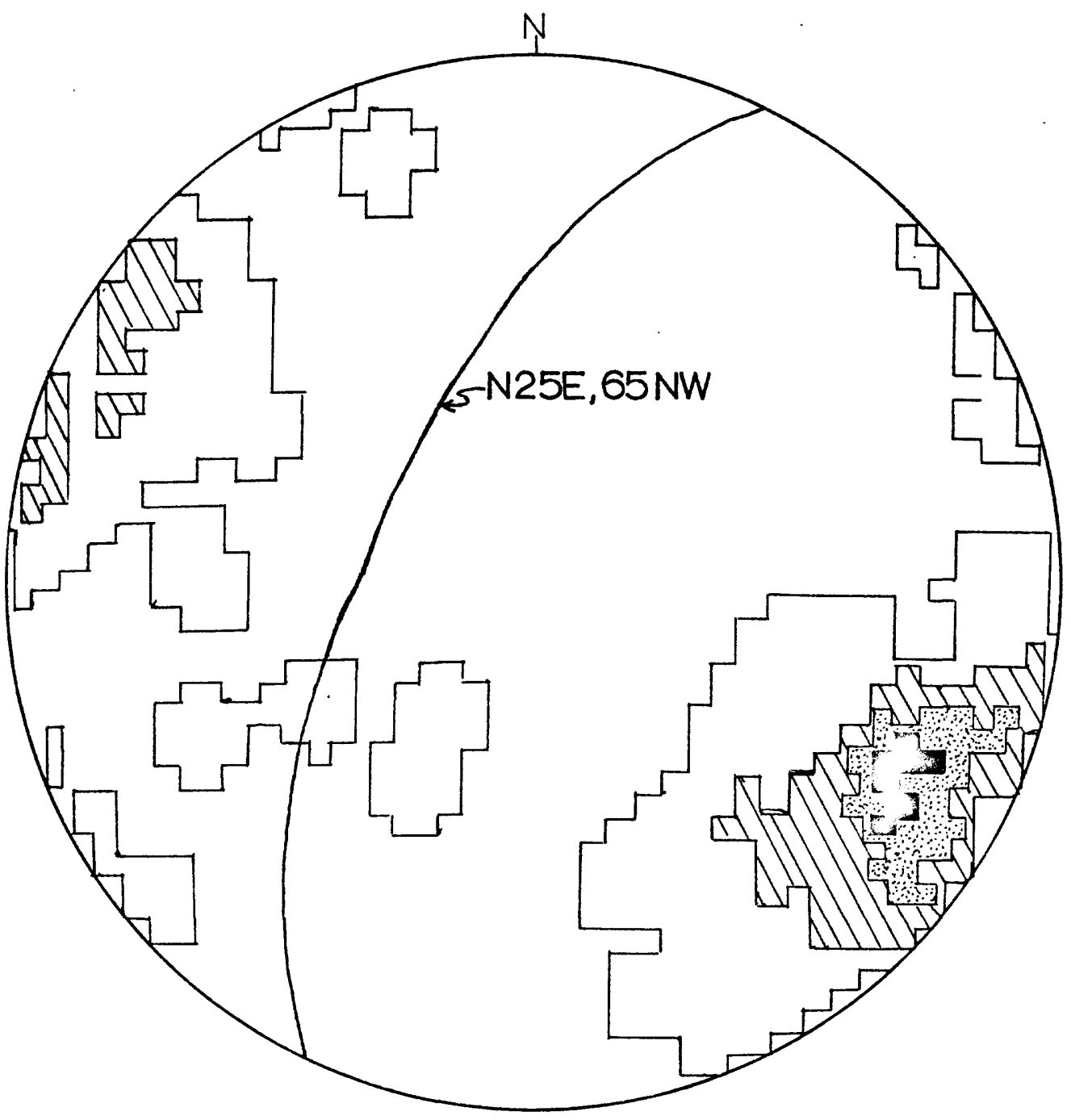

Figure 23. Lower hemisphere equal-area projection of 134 poles to the S3 foliation from subareas 1, 2, and 3 . Plane of projection is horizonta1. Contour intervals are $0.75 \%, 4.48 \%, 8.21 \%$, and $11.94 \%$ per one percent area. Solid line is the surface located by the point maximum. 
S2 foliation in subareas 1, 2, and 3 are plotted on a lower hemisphere equal, area projection in Figure 24. The contoured poles locate a plane oriented N12E, 88SE.

Major Structures in Subarea 3

In subarea 3 , the reversal of rotation sense on the limbs of the mapped folds, plus lithic hooks, suggest superposed folds. The contacts represent superposition of tight to open, northeast F3 folds upon isoclinal to tight, northeast F2 folds. F3 folds superposed upon F2 folds are also visible in outcrop. In addition, S3 is warped by open F4 folds (P1ate 4).

The contact at the base of the green and tan schists and phyllites (ucs) is interpreted as a fault contact based on omission and truncation of units. In addition, metamorphosed dikes intrude the schists and phyllites (within $30 \mathrm{~m}$ of the contact with the Ottauquechee Fm.), but are not present in any rocks to the west. More work is needed in this area to substantiate the configuration of this contact (area was traversed, but contacts were not walked), and to determine the relationship of the fault to the fold deformation.

Summary and Discussion

Based on evidence presented here and in Chapter 2, the rocks in the study area are best divided into four structural packages:

Hazens Notch Formation; Belvidere Mountain Complex; Ottauquechee Formation; Stowe Formation. Additional faults exist within the packages. The present structural position of these rocks is the result of both fold and fault deformation. 


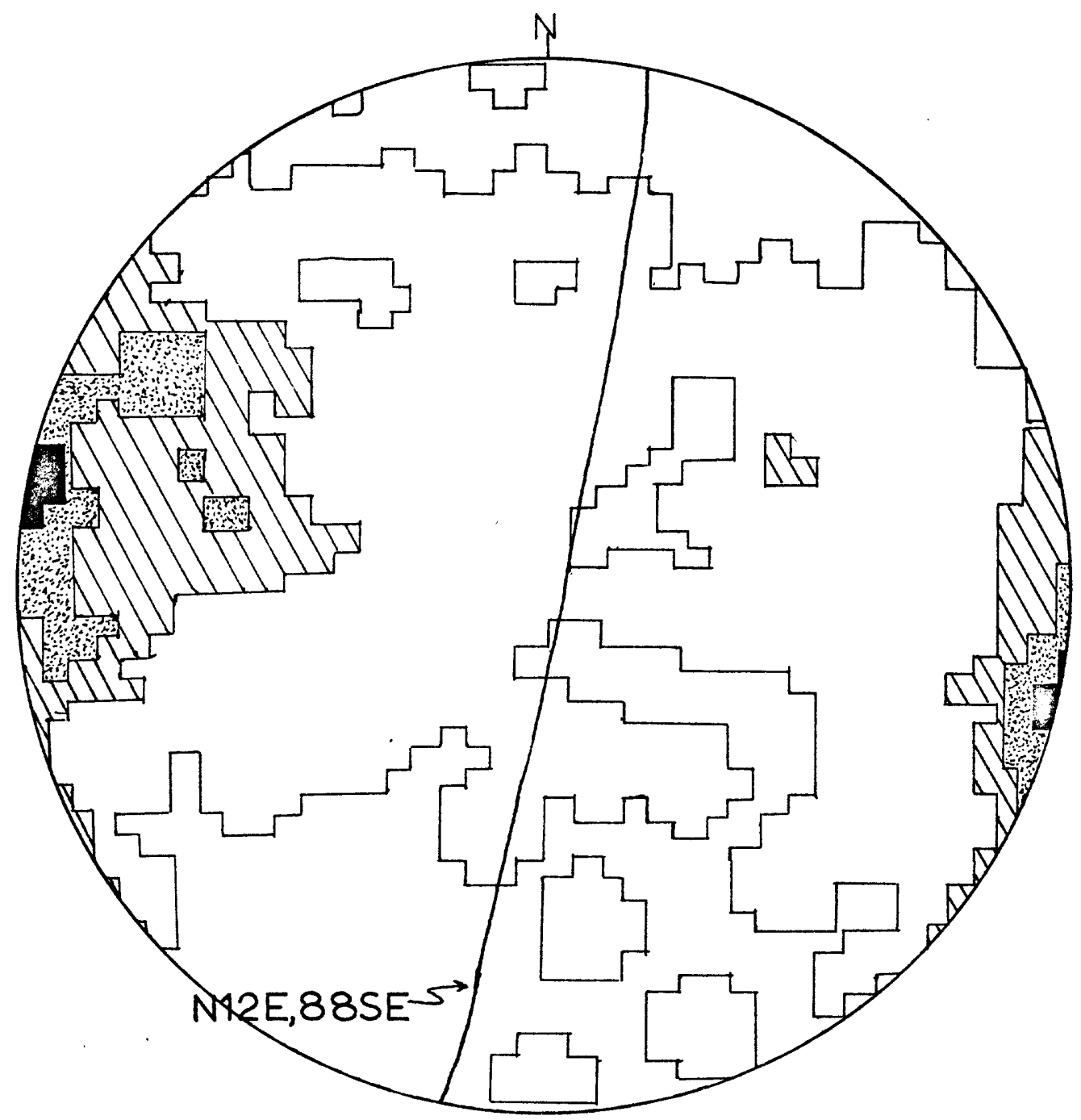

Figure 24. Lower hemisphere equal-area projection of 272 poles to the S2 foliation in subareas 1,2 , and 3 . P1ane of projection is horizontal. Contour intervals are $0.37 \%, 2.57 \%, 4.78 \%$, and $6.9 \%$ per one percent area. Solid line is the surface located by the point maximum. 
The superposition of minor folds and foliations, plus the map pattern, indicate four fold events in subareas 1 and 2 . Preliminary work suggests that the folds and foliations in the rocks on Hadley Mountain are correlative, by style and orientation, with the three most recent events in subareas 1 and 2 (F2, F3, F4). The failure to recognize $\mathrm{Fl}$ and $\mathrm{S} 1$ in the rocks on Hadley Mountain may be explained in several ways: $\mathrm{S} 1$ is present but was overlooked in the phyllitic rocks; Sl is present, but was not recognized because subsequent deformation completely transposed the early cleavage; S1 is not present, suggesting a different history for the rocks on Hadley Mountain. It is not clear which explanation represents the geology on Hadley Mountain. However, Cady et al. (1963) noted the confinement of the major "transverse" structures (F1 in this study) to rocks west of the Stowe Formation.

The faults in the study area exhibit varying relationships to the folds. The relationship of the fault at the base of the Stowe Formation to the fold events is not-clear. F1 structures are not recognized in the Stowe Formation, and thus the fault may be post-Fl. In addition, the exact nature of the contact of the Stowe Formation and Ottauquechee Formation is not known, and the fault here may actual-1y be closely related to F2 folds. The western contact of the Ottauquechee Formation is a fault contact with the Belvidere Mountain Complex. This fault appears as a linear structure nearly parallel to the axial surface of F2 folds. Thus, this fault contact is interpreted as pre- to syn-F2.

A1l faults in subareas-1 and 2 are folded by F2, F3, and F4. The relationship of the faults to $F 1$ is less clear. The first defor- 
mation in subareas 1 and 2 may in fact represent a long history of folding and faulting associated with the emplacement of the mafic and ultramafic rocks (Belvidere Mountain Complex), and is thus more aptly termed D1. In addition, the serpentinite may have responded by minor slip during any of the fold events.

The fault deformation in subareas 1 and 2 is best characterized by the underplating of successively higher rocks at the base of $(\operatorname{serp})$

the serpentinite $\wedge^{\text {as }}$ illustrated in Figure 25 . This fault event culminates in the juxtaposition of the ultramafic rocks and metamorphosed mafic rocks (bac, baf, bgs) onto/into metasedimentary rocks (mus). Continued fold deformation (F1) is responsible for folding of this early fault sequence, which is subsequently faulted against the underlying metasedimentary rocks ( $\mathrm{rs}$, agn, ss, wgn), as is evidenced by the truncation of the early (F1) fold structures in the Belvidere Mountain Complex against the albite gneiss and rusty schist of the Hazens Notch Formation.

The underlying metasedimentary package (Hazens Notch Formation) also attests to four fold events. Thus, the metasedimentary rocks also record the early F1 minor structures. Therefore, it appears that the early deformation (D1) is characterized both folding and faulting under essentially the same stress field orientation. This constraint would account for the near impossibility of separating pre-fault from post-fault F1 minor structures. All these early structures are deformed by F2 isoclinal folds, F3 tight to open folds, and F4 open folds. 

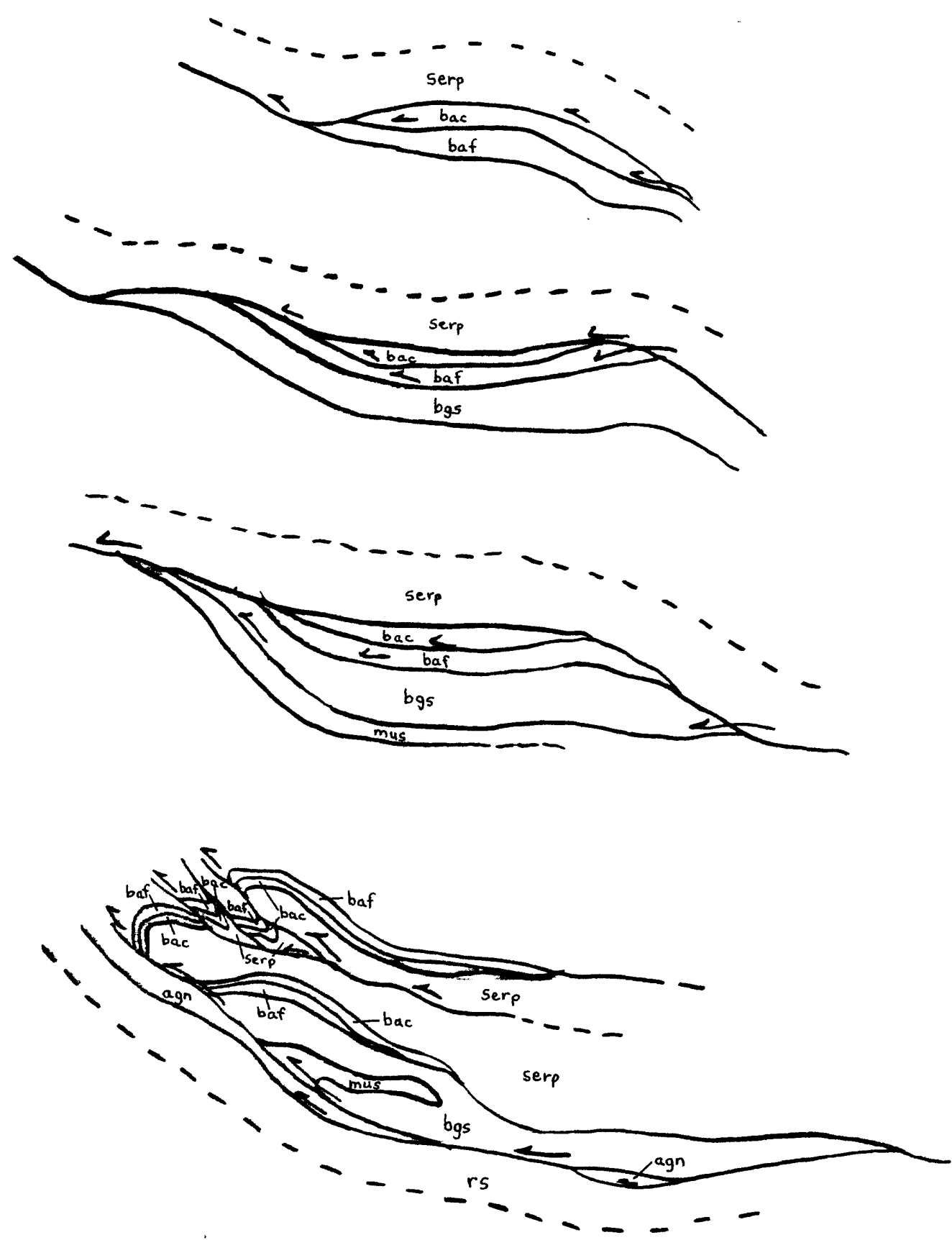
$O$ serp
Obac
Obaf
Obgs
mus
Oagn
Ors

Figure 25. Schematic of emplacement of the ultramafic rocks and underplated fault slivers. Not drawn to scale. All stages are postulated to represent pre-S2 time. 
Structural Correlation with Previous Works

Osberg (1965) noted three fold generations in correlative rocks to the north on the eastern flank of the Sutton Mountain Anticlinorium in Quebec. He defined F1 as northwest to west trending folds, F2 as N42E to N60E trending folds, and F3 as N20E to N35E trending folds. In this report, F1 folds are east-northeast striking, tight to isoclinal overturned folds. F2 folds are isoclinal to tight folds with an axial surface striking N10E to N26E. F3 folds are tight to open folds with an axial surface striking N1OE to N34E. The control on the F4 folds is minimal, although they appear to be late northnortheast folds.

Eiben (1976) also recognized three fold generations in the Cambrian rocks, just west of the Green Mountain Anticlinorium, in the Camels Hump Quadrangle. The early folds exhibit variable orientations, although on an equal-area projection the axial planes locate a diffuse girdle oriented N59W, 77N (Eiben, 1976). The axial planes of F2 folds strike N-NE and dip to the west. The axial planes of F3 folds strike north and dip east.

Thompson (1975) recognized three fold generations in the lower Cambrian rocks of the Came1s Hump Group just west of the Green Mountain Anticlinorium. He recognized early, F1 east-west folds, F2 isoclinal northeast trending folds, and F3 north-northeast trending folds. Thompson (1975) also suggested the possibility of large scale, open F4 folds with a northwest trending fold axis. Although he did not recognize $F 4$ folds in the field, he postulated their existence based on the variation in the orientation of 53 . The fold relations discussed above are summarized in Figure 26. 


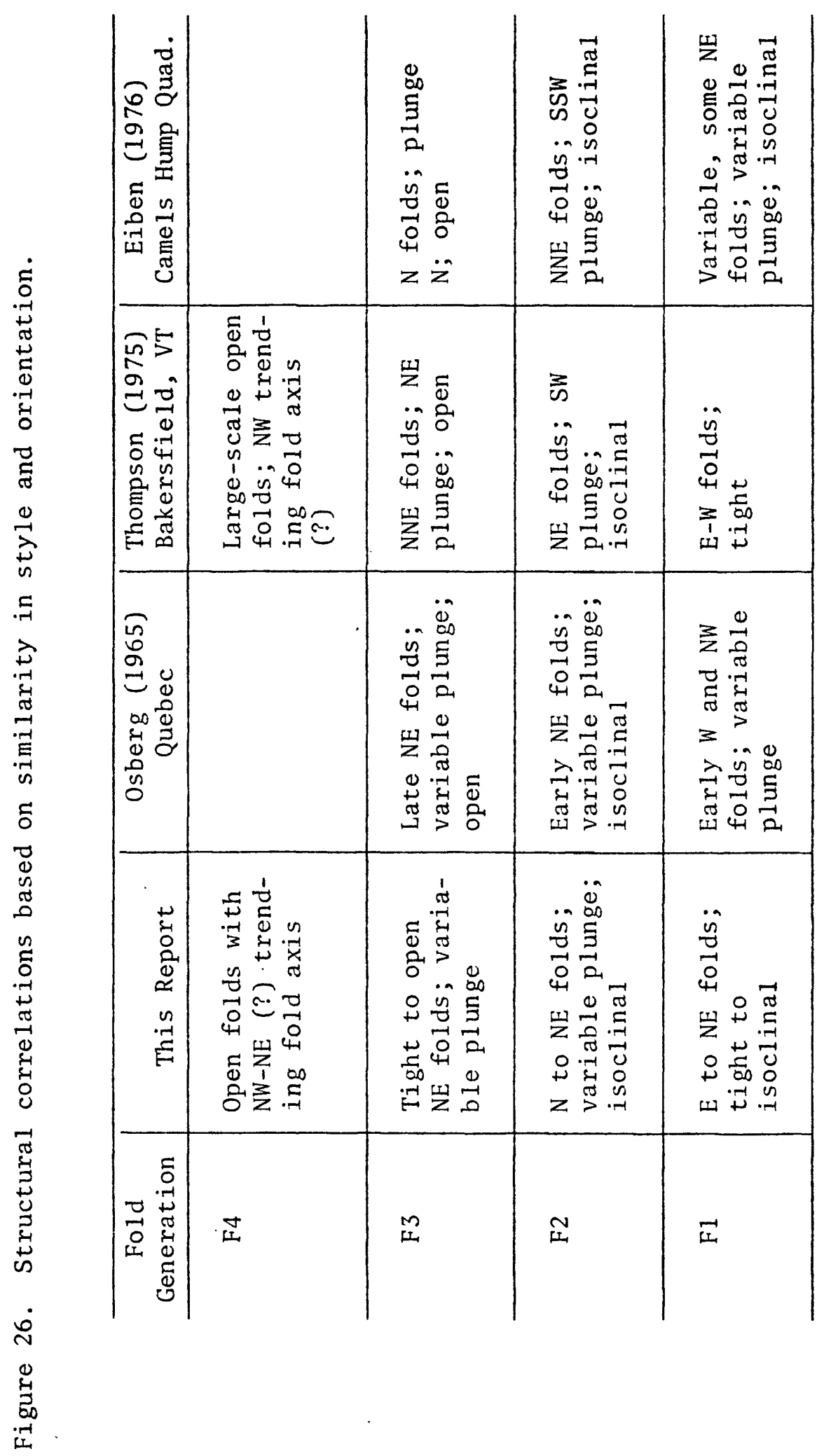


Chapter 4

CHEMISTRY OF THE MAFIC ROCKS

The chemistry of the greenstone and amphibolites is used here to establish the chemical characteristics of these mafic rocks, and to aid in the determination of a protolith. The chemical analyses and histograms for the major elements and trace elements are listed in Appendix 2. Each sample is briefly described in Appendix 1, and sample locations are shown on Plate II.

Averages of the analyses of the mafic rocks are given in Table 2, and analyses of basalts, metabasalts, and gabbros from the MAR, and garnet-amphibolites from Thetford Mines, Quebec, are listed for comparison. All rocks exhibit similar major and trace element chemistry. Consideration of the major and trace element analyses for the greenstone and amphibolites in the study area shows these rocks to be chemically alike.

Histograms of $\mathrm{SiO}_{2}, \mathrm{TiO}_{2}$, and $\mathrm{Fe} 0 * / \mathrm{MgO}$ for the mafic rocks at Belvidere Mountain are similar to those for ocean floor basalts and gabbros (Fig. 27, 28). High $\mathrm{Fe} 0^{*}-\mathrm{MgO}$ relative to $\mathrm{Na}_{2} \mathrm{O}+\mathrm{K}_{2} \mathrm{O}$ for the greenstone and amphibolites is shown on the FMA diagram in Figure 29. Most analyses plot close to the average MAR basalt (Fig. 29).

Although some element mobility during weathering and/or metamorphism is to be expected (Pearce, 1975) the fairly uniform chemistry of the rocks, plus the strong chemical correlation with ocean floor rocks, suggests that any migration has been minimal. The 
Table 2

Average Chemical Analyses

\begin{tabular}{|c|c|c|c|c|}
\hline & $A$ & $B$ & c & $D$ \\
\hline \multirow{5}{*}{$\begin{array}{l}\mathrm{SIO}_{2} \\
\mathrm{I}_{2} \mathrm{O}_{2} \\
\mathrm{AL}_{2} \mathrm{O}_{3} \\
\mathrm{Fe}_{2} \mathrm{O}_{3} \\
\mathrm{~F} \mathrm{OO}\end{array}$} & 46.76 & 46.35 & 46.83 & 46.79 \\
\hline & 1.18 & 1.00 & 1.25 & 1.12 \\
\hline & 14.00 & 17.09 & 13.87 & 12.82 \\
\hline & 5.94 & 5.03 & 6.28 & - \\
\hline & 6.15 & 9.46 & 5.74 & - \\
\hline $\mathrm{MnO}_{\mathrm{n}}$ & 0.20 & 0.21 & 0.20 & - \\
\hline 480 & 7.36 & 8.67 & 7.09 & 10.04 \\
\hline CaO & 9.34 & 10.26 & 9.14 & 12.11 \\
\hline $\mathrm{Na}_{2} \mathrm{O}$ & 2.43 & 2.09 & 2.50 & 2.20 \\
\hline$x_{2}{ }^{0}$ & 0.20 & 0.25 & 0.19 & 0.26 \\
\hline $\mathrm{P}_{2} \mathrm{O}_{5}$ & 0.10 & 0.04 & 0.11 & 0.47 \\
\hline $\mathrm{H}_{2} \mathrm{O}^{\circ}$ & : & - & * & - \\
\hline $\mathrm{H}_{2} \mathrm{O}^{-}$ & - & - & - & - \\
\hline Poo & 11.45 & 11.86 & 11.36 & 12.99 \\
\hline$P 00=/ M_{5} 0$ & 1.56 & 1.37 & 1.60 & 1.29 \\
\hline Ba & 37 & 41 & 36 & * \\
\hline Cr & 159 & 100 & 174 & - \\
\hline Cu & 87 & 121 & 78 & - \\
\hline Ga & 19 & 20 & 19 & - \\
\hline II & - & - & - & • \\
\hline $\mathrm{NI}$ & 93 & 94 & 93 & - \\
\hline $\mathrm{Nb}$ & 9 & 7 & 10 & - \\
\hline$P b$ & 3 & 1 & 4 & - \\
\hline$R B$ & 8 & 5 & 9 & - \\
\hline ST & 121 & 78 & 132 & - \\
\hline $\mathbf{v}$ & 340 & 322 & 345 & - \\
\hline$Y$ & 33 & 30 & 34 & - \\
\hline $2 n$ & 123 & 104 & 128 & - \\
\hline 25 & 82 & 54 & 89 & - \\
\hline
\end{tabular}

A Average of 41 samples of greenstone, fine gralned amphibolite, and coarse grained amphlbolite from Belvidere Mountaln.

B Average of 7 coarse grained and fine grained amphibolltes from Belvidere Mountain.

C Average of 34 greenstones from Belvidere Mountain.

D Average of 10 aureole rocks frow Thetford ulnes, Quebec (Brackett, 1979).

\begin{tabular}{|c|c|c|c|c|}
\hline $\mathbf{E}$ & $P$ & $G$ & H & \\
\hline 42.52 & 49.58 & 49.21 & 49.95 & $\mathrm{SIO}_{2}$ \\
\hline 1.12 & 1.54 & 1.39 & 1.49 & $\mathrm{TIO}_{2}$ \\
\hline 16.33 & 15.25 & 15.81 & 15.72 & $\mathrm{AI}_{2} \mathrm{O}_{3}$ \\
\hline 2.65 & 2.50 & 2.21 & - & \\
\hline 8.35 & 6.35 & 7.19 & 7.56 & $P=0$ \\
\hline 0.19 & 0.16 & 0.16 & .0 .16 & Mno \\
\hline 11.15 & 9.24 & 8.53 & 9.27 & MgO \\
\hline 13.22 & 7.12 & 11.14 & 11.16 & $C=O$ \\
\hline 1.05 & 3.56 & 2.71 & 2.70 & $\mathrm{Na}_{2} \mathrm{O}$ \\
\hline 0.19 & 0.05 & 0.26 & 0.08 & $x_{2}{ }^{0}$ \\
\hline 0.11 & 0.14 & 0.15 & 0.03 & $\mathrm{P}_{2} \mathrm{O}_{5}$ \\
\hline 2.50 & 3.14 & 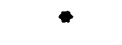 & 2.22 & $\mathrm{H}_{2} \mathrm{O}^{+}$ \\
\hline 0.02 & 0.88 & - & 2.22 & $\mathrm{H}_{2} \mathrm{O}^{-}$ \\
\hline- & & - & • & $F \in 0$ \\
\hline- & $\bullet$ & 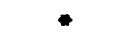 & - & $\mathrm{FeO} / \mathrm{MgO}$ \\
\hline 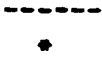 & 7 & 12 & 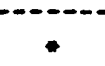 & Ba \\
\hline 563 & 230 & 296 & - & Cr \\
\hline$*$ & 75 & 87 & - & Cu \\
\hline- & 23 & 18 & $\bullet$ & Ga \\
\hline- & 19 & 8 & - & II \\
\hline 208 & 107 & 123 & - & $\mathrm{NI}$ \\
\hline - & $\bullet$ & - & - & $\mathrm{Nb}$ \\
\hline - & 11 & 2 & - & $\mathrm{Pb}$ \\
\hline - & $\bullet$ & - & - & $\mathbf{R B}$ \\
\hline - & 13 & 123 & - & sr \\
\hline- & 243 & 289 & - & $\mathbf{v}$ \\
\hline - & $\bullet$ & 43 & - & $\mathbf{Y}$ \\
\hline- & 166 & 122 & - & $2 n$ \\
\hline$\bullet$ & 105 & 105 & - & $2 r$ \\
\hline
\end{tabular}

E Gamet amphibolite, Thetford Mines, Quebec (Iaurent, 1977).

$F$ Mean of three greenstones from the MAR $22 \mathrm{~N}$ (Thompson and Melson. 1972).

$G$ Hajor elements s mean of 33 basalts Iror the MAR. Trace elementsi mean of 20-30 oceanic tholeitic basalts (Thompson and Melson, 1972).

$H$ Average of five gabbros from the MAR (Miyashito, 1970).

- Value not reported. 

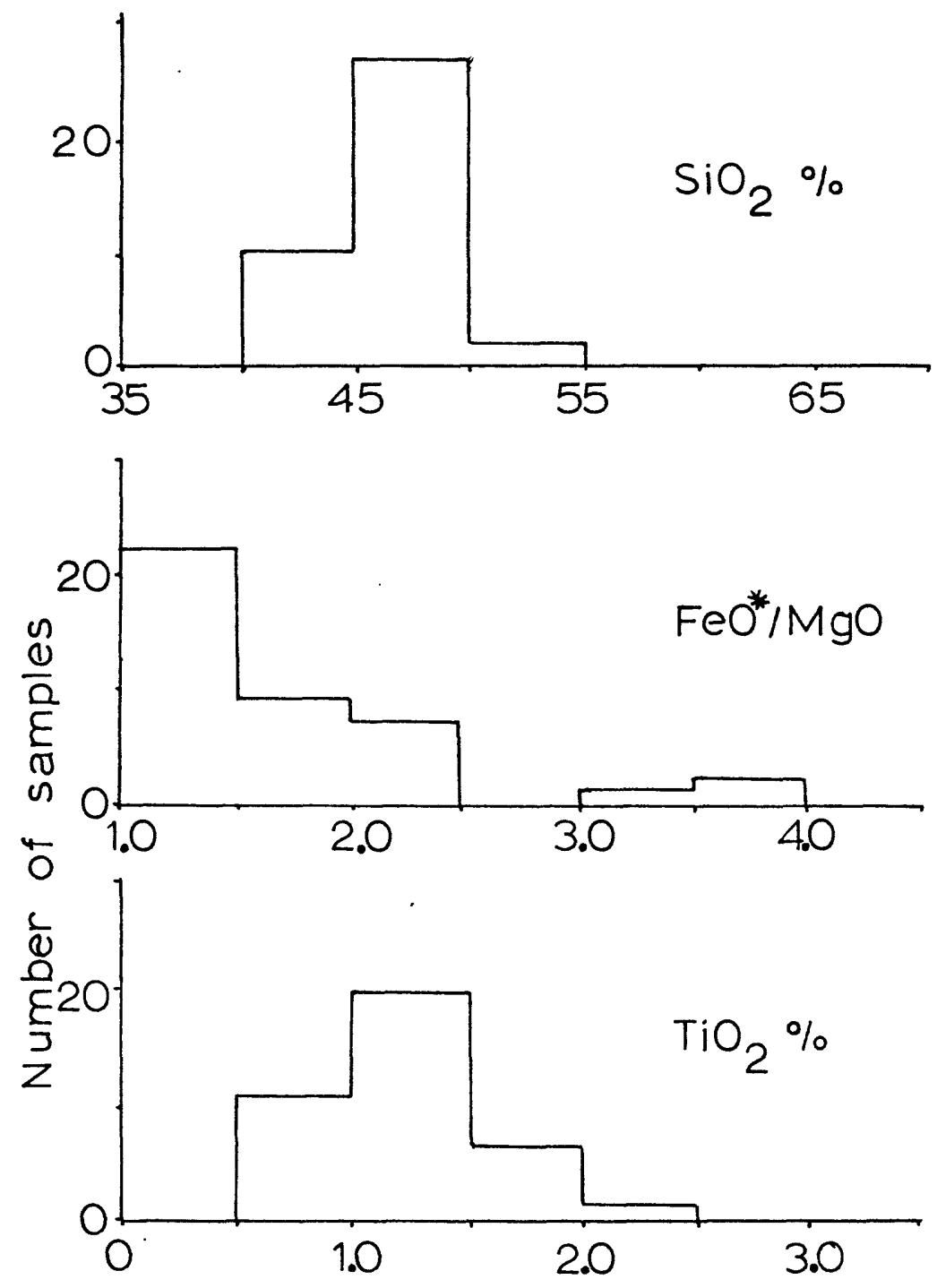

Figure 27. Frequency distribution of $\mathrm{SiO}_{2}, \mathrm{TiO}_{2}$, and $\mathrm{Fe} 0 * / \mathrm{MgO}$ for greenstone and amphibolites from the Belvidere Mountain area. 


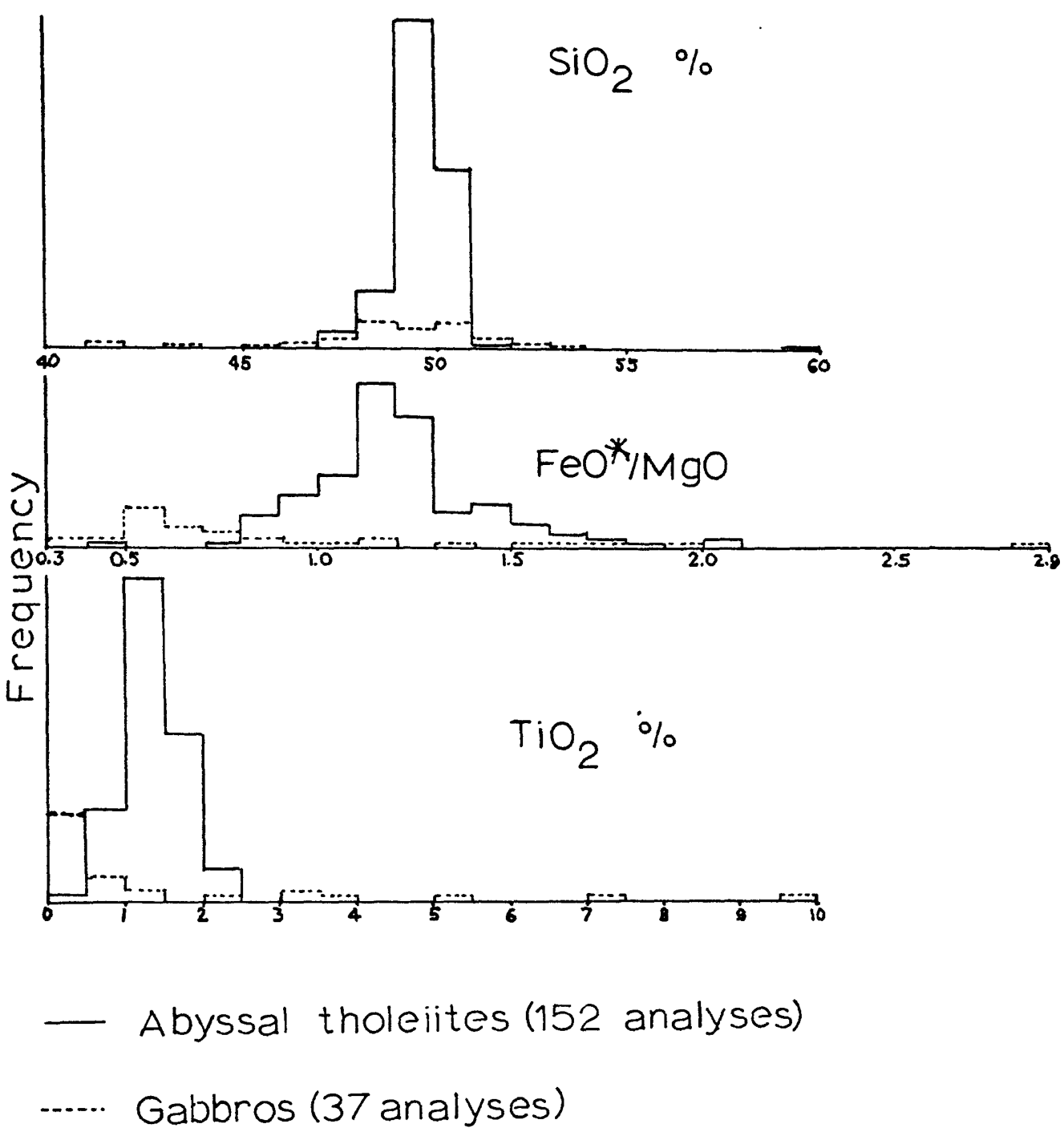

Figure 28. Frequency distribution of $\mathrm{SiO}_{2}, \mathrm{TiO}_{2}$, and $\mathrm{Fe} 0 * / \mathrm{MgO}$ for ocean floor basalts and gabbros (after Miyashiro, 1975). 


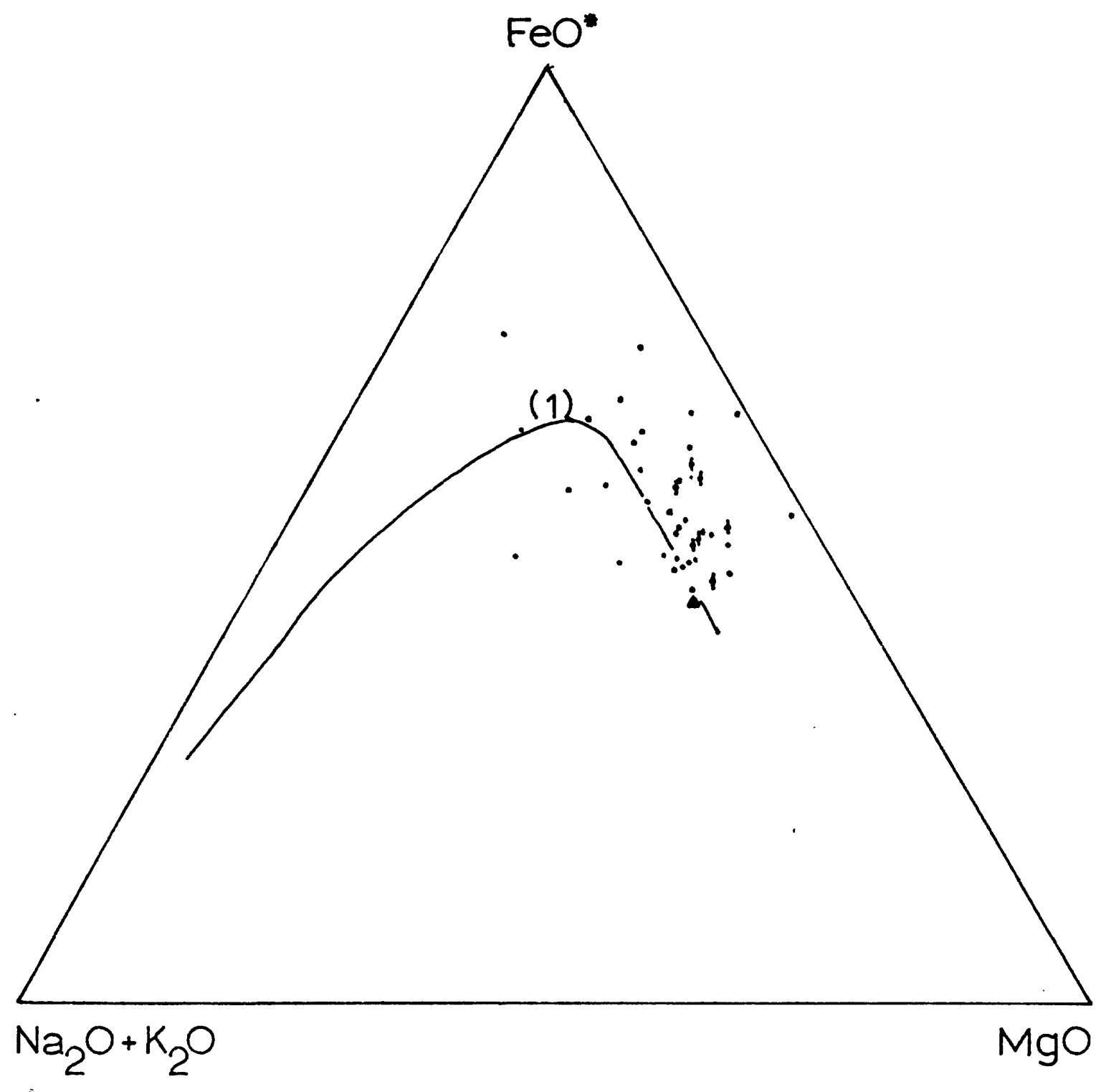

Figure 29. FMA diagram of greenstone ( $\cdot$ ) and amphibolites (1) from the Belvidere Mountain area. $\Delta:$ average MAR basalt. (1) Thingmuli trend given for reference. 
chemistry of the greenstone and amphibolites is consistent with ocean floor basalts and with other aureole rocks.

Trace elements are also useful for determining the chemical affinities of the rocks at Belvidere Mountain. Pearce and Cann (1973) have found that the $\mathrm{Y} / \mathrm{Nb}$ ratio may be used for distinguishing alkalic rocks ( $\mathrm{Y} / \mathrm{Nb}$ less than 2) from tholeiitic basalts ( $\mathrm{Y} / \mathrm{Nb}$ greater than 2) The $\mathrm{Y} / \mathrm{Nb}$ ratio for most samples of the greenstone and amphibolites is greater than 3, although four samples have ratios greater than 2 . The trace elements are plotted on the discriminant plots for volcanic rocks of Pearce and Cann (1973) and Pearce (1975) in Figures 30-32. The $\mathrm{Ti} / 100-\mathrm{Zr}-\mathrm{Y} \cdot 3$ plot serves mainly to distinguish withinplate basalts from low-potassium tholeiites, calc-alkalic basalts, and ocean floor basalts (Pearce and Cann, 1973). All analyses of the rocks in the study area plot well away from the within-plate basalt field, and most lie in the ocean floor basalt region (Fig. 30). The mafic rocks are also plotted on the Ti-Zr diagram (Fig. 31) and the Ti/100-Zr-Sr/2 plot (Fig. 32) from Pearce and Cann (1973) which are useful for distinguishing ocean floor basalts, calc-alkalic basalts, and low-potassium tholeiites. In each plot, most analyses plot within the ocean floor basalt region. Two samples $(221,268)$ plot consistent1y away from the rest of the mafic rocks due to the high $\mathrm{Zr}$ values for these samples. The samples are from the narrow exposure of greenstone within the rusty schist (Plate II), and the chemistry may reflect a different greenstone. The discriminant plots for the trace elements support an ocean floor tholeiite chemical affinity for the amphibolites and greenstone in the Belvidere Mountain area. 


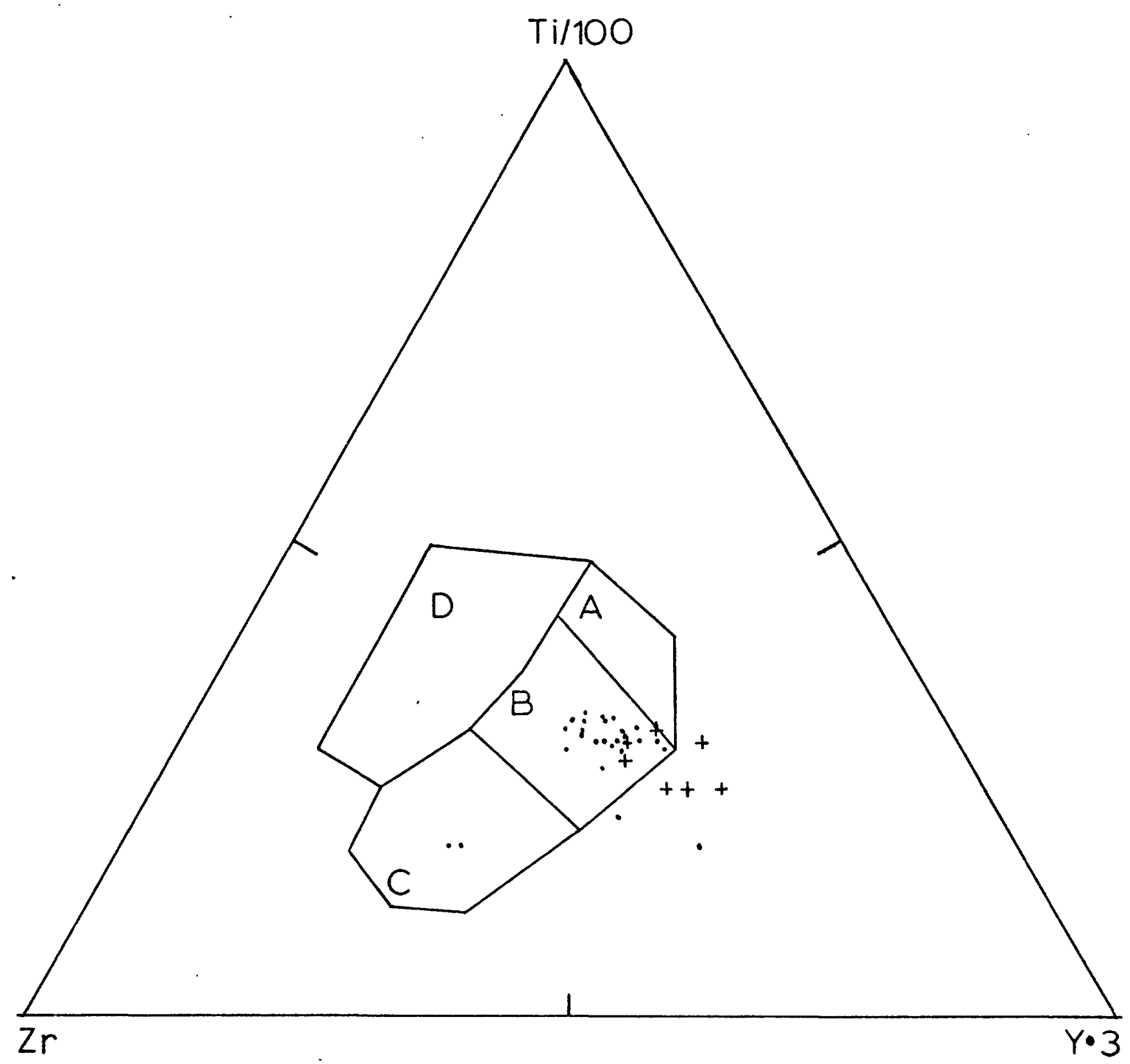

Figure 30. Ti/100-Zr-Y 3 plot of the greenstone $(\cdot)$ and amphibolites (+) from the Belvidere Mountain area (after Pearce and Cann, 1973); low-potassium tholeiites in fields $A$ and $B$, calc-alkalic basalts in fields $C$ and $B$, ocean floor basalts in field $B$, within-plate basalts in field $D$. 


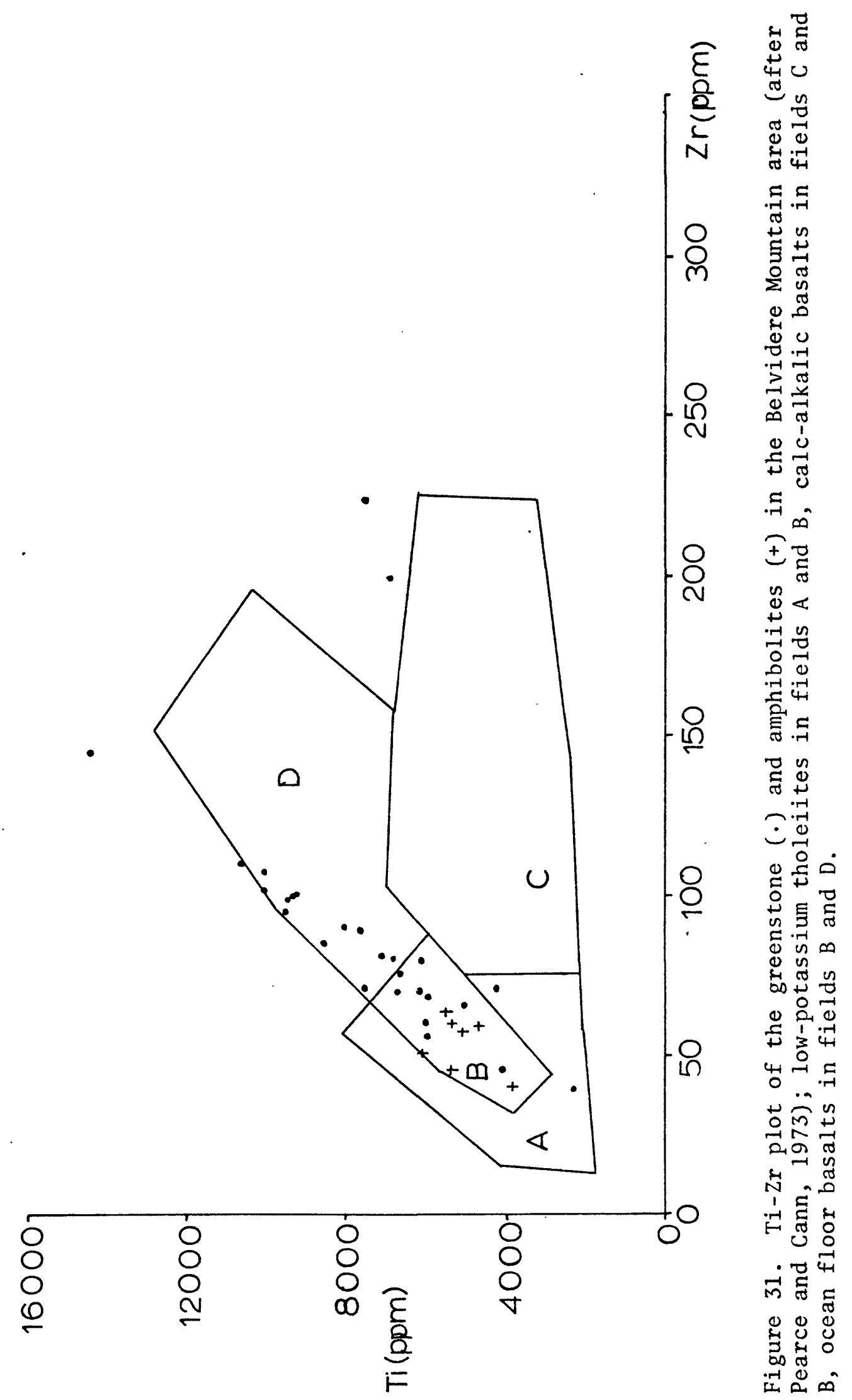




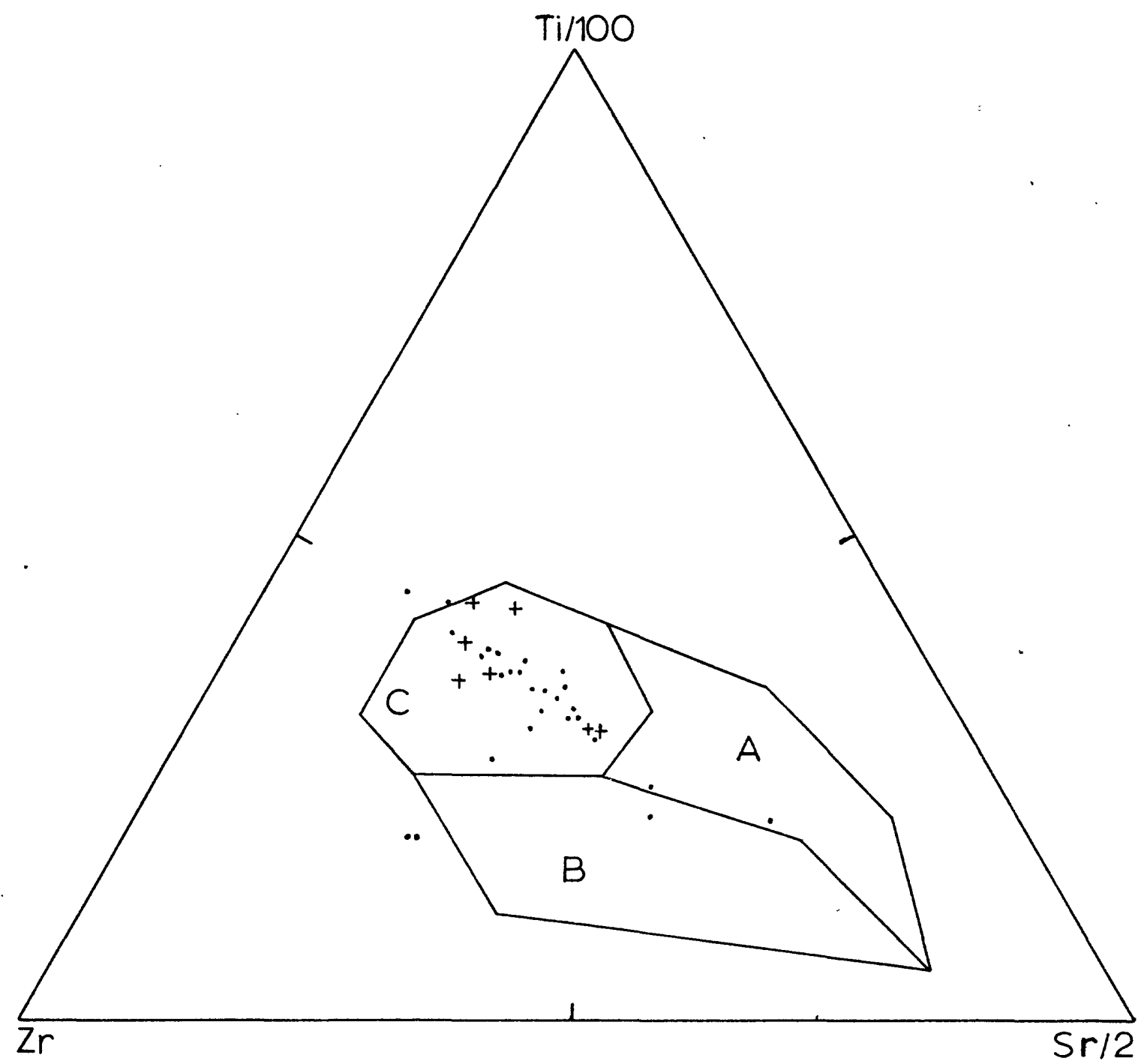

Figure 32. Ti/100- $\mathrm{Zr}-\mathrm{Sr} / 2$ plot of the greenstone ( $)$ and amphibolites (+) from the Belvidere Mountain area (after Pearce and Cann, 1973); low-potassium tholeiites in field A, calc-alkalic basalt in field B, ocean floor basalt in field $C$. 
In conclusion, the amphibolites and greenstone in the Belvidere Mountain area are chemically alike. The chemical similarities of the greenstone and amphibolites, coupled with field and petrographic data, suggests that these rocks have the same protolith. These mafic rocks are chemically similar to ocean floor basalts and gabbros, as well as to other aureole rocks associated with ophiolites. Trace element chemistry supports an ocean floor tholeiite chemistry for the mafic rocks. Element mobility/migration appears minimal in the mafic rocks of the study area. Thus, it is suggested that the protolith(s) for the mafic rocks of the Belvidere Mountain Complex are ocean floor basalts and/or gabbros. 


\section{Chapter 5}

\section{PETROGRAPHY AND METAMORPHISM OF THE MAFIC ROCKS}

\section{Introduction}

The structure of the Belvidere Mountain area represents a deformational history of fold and fault events. In this chapter, the petrography and metamorphism of the mafic rocks are discussed and compared with the metasediments in order to relate metamorphism to structural events. The emphasis is placed on the relationships of mineral growth and alteration to the observed minor and major structures. Textural criteria for distinguishing mineral growth are those discussed by Spry (1969) and Johnson (1961). This information provides additional constraints regarding the deformational history of the Belvidere Mountain area.

The metamorphic rocks in the area have been previously assigned to the biotite and garnet zones (Do11 et a1., 1961). Cady et a1. (1963) defined a hornblende isograd at Belvidere Mountain to separate greenschist facies from epidote-amphibolite facies mafic rocks. This isograd is shown as a garnet isograd by Doll et al. (1961)

Cady et al. (1963) proposed a Middle Devonian age for most of the deformation and metamorphism in this area, although Albee (1968) later suggested a Middle Ordovician age for the metamorphism of the rocks in the region. Lanphere and Albee (1974) obtained a date of $457 \pm 26 \mathrm{~m} . y$. for metamorphism of the greenstone in the Stowe Forma- 
tion east of Burnt Mountain in the Worcester Range. They conclude that this date reflects Late Ordovician regional metamorphism. Laird and Albee (1975) propose a high pressure Taconic metamorphism of amphibolite at Tillotsen Peak. Most recently, Laird (1977) used the compositions of amphiboles, plagioclase feldspar, white mica, and carbonates, plus overgrowth relations in amphiboles, to develop a metamorphic history for Vermont. She tentatively assigned the metamorphism in the Belvidere Mountain area to two Ordovician, medium to high pressure facies series events followed by Devonian medium to. low pressure facies series metamorphism.

In this study, two and three metamorphisms are recognized and correlated with the early (Taconic ?) F1/D1 and F2 deformation events.

Greenstone, bgs

The greenstone is a fine grained, green, buff-weathering rock composed of varying amounts of chlorite, albite, actinolite, epidote, calcite, quartz, sphene, biotite, and opaque minerals (Table 3). Albite porphyroblasts are commonly present in a fine grained matrix of chlorite, actinolite, and epidote which are aligned parallel to the S2 schistosity. Due to the F2 isoclina1 folds, S1 and S2 are parallel except at $\mathrm{F} 2$ fold hinges. Thus, in many samples it is not possible to separate the mineralogy associated with $F 1$ and F2.

Chlorite. The amount of chlorite in the greenstone varies from $2 \%$ to $51 \%$. Chlorite is pleochroic in yellow and green, and displays anomalous brown birefringence.

Chlorite occurs as discrete anhedral grains, in scaly aggregates, and in clumps. In some samples, chlorite aggregates occur as 
89

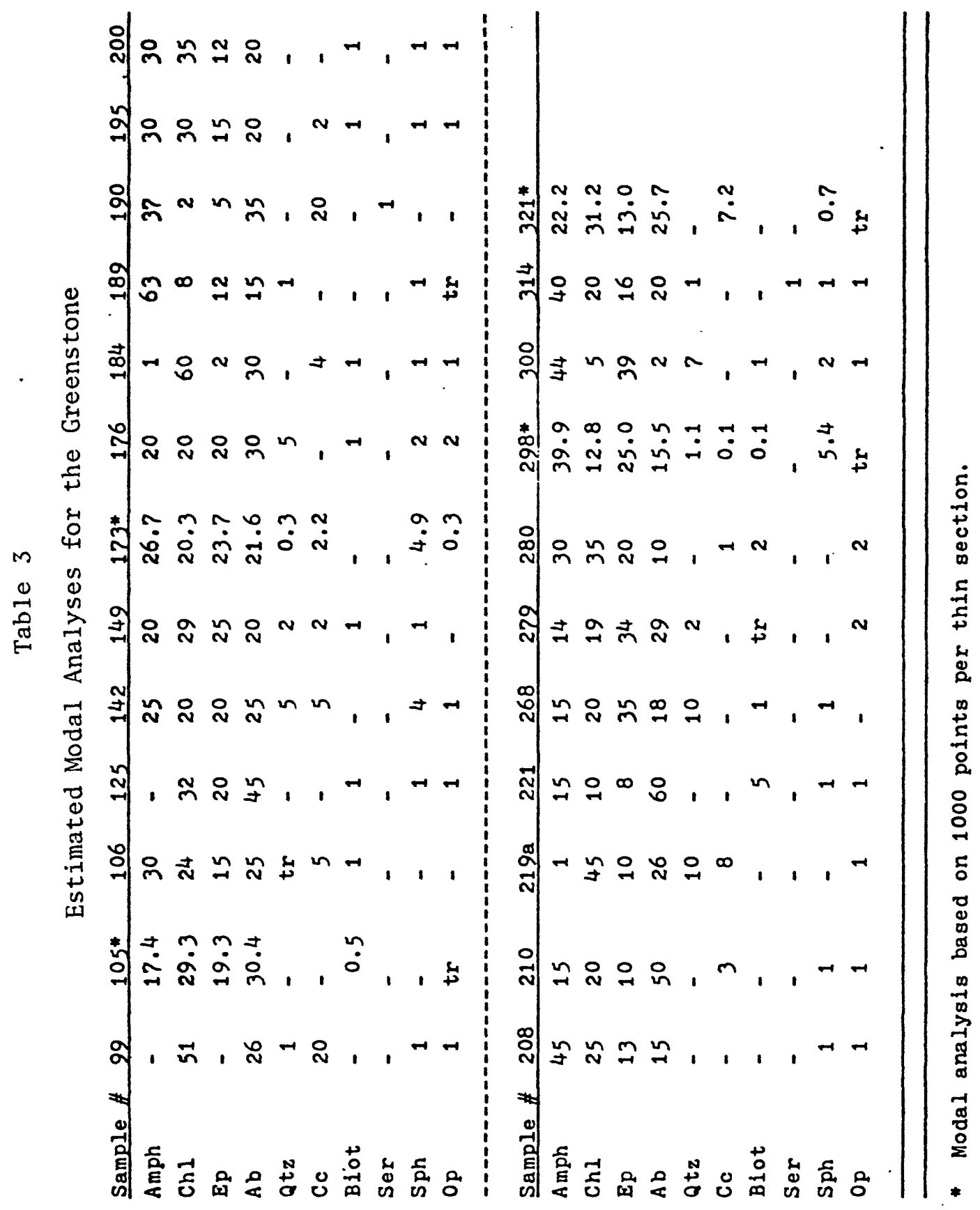


porphyroblasts after garnet (Fig. 33). The S2 schistosity wraps around the porphyroblasts, and the alteration of garnet to chlorite may be associated with either F1/S1 or F2/S2. However, ch1orite is present as inclusions in albite porphyroblasts where it appears as a pseudomorph of garnet (Fig. 34). The albite porphyroblasts are presyn F2, with S1 helicitic textures, thus suggesting that the alteration of garnet to chlorite is associated with F1/S1.

Most commonly, chlorite is concentrated in layers (paralle1 S1) either solely or associated with actinolite and/or epidote. It is intimately interleaved with actinolite in bands parallel to S1/S2, and as such, constitutes a matrix for elongate albite porphyroblasts. Chlorite is rotated into parallelism with $\mathrm{S} 3$ along the crests and troughs of F3 crenulate folds.

Epidote group. The percentage of epidote in the greenstone varies from zero to $39 \%$. The composition varies from clinozoisite to pistacite (Chidester et al., 1978). Epidote occurs as distinct anhedral to subhedral grains which are either colorless, or exhibit faint yellow and green pleochroism. Many of the epidote grains are multiply zoned, and the core may exhibit either higher or lower birefringence than the rim. In addition, some grains are twinned.

Epidote is present as inclusions in albite porphyroblasts, in small pods with calcite, as single grains randomly distributed throughout the sample, as single grains aligned parallel to the $\mathrm{S} 2$ schistosity, and in epidote-rich bands parallel to Sl. Epidote also occurs as porphyroclasts in a finer grained matrix of actinolite, chlorite, and epidote (Figs. 35, 36). These larger grains are frag- 


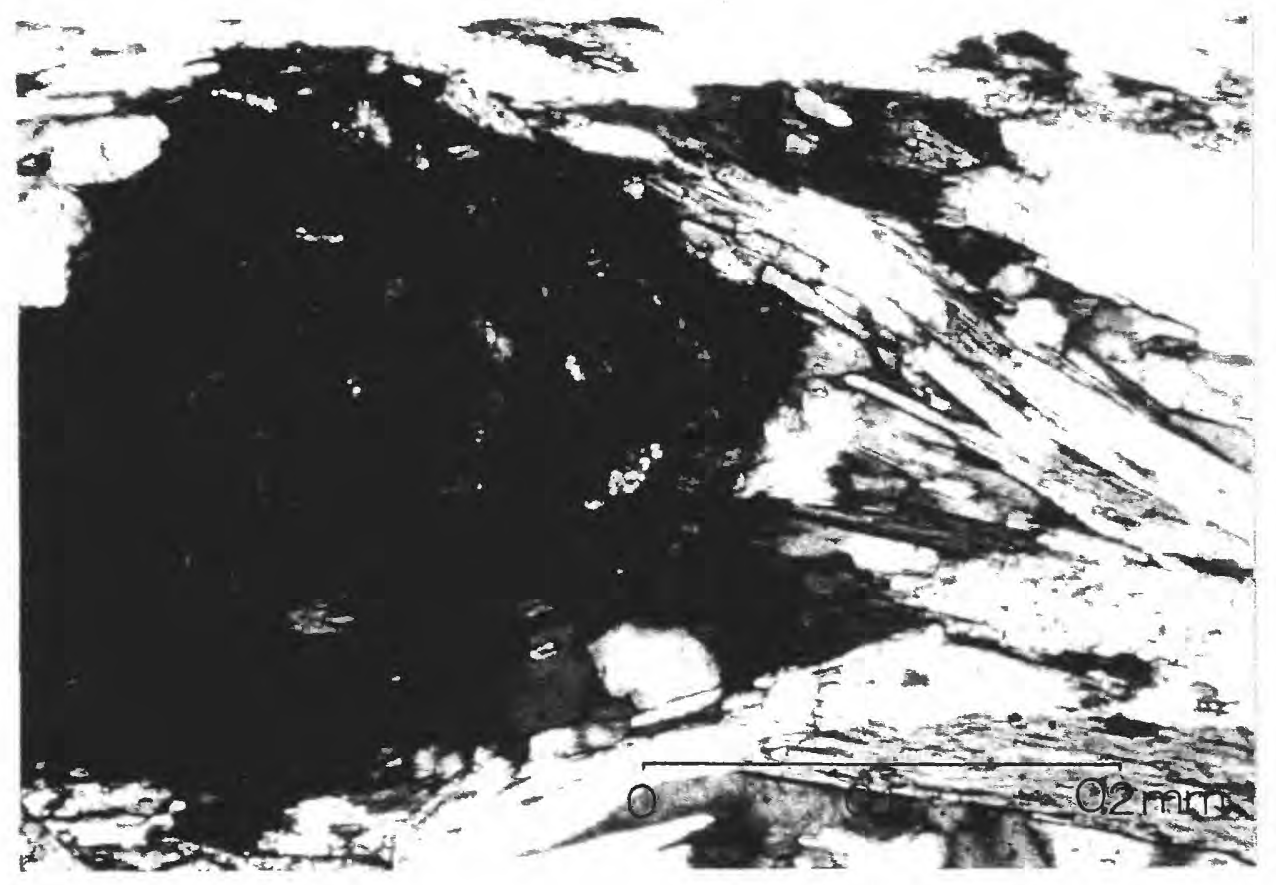

Figure 33. Pre-s2 chlorite aggregate. $\$ 2$ defined by alignment of actinolite. Bgs-300. X-nicols.

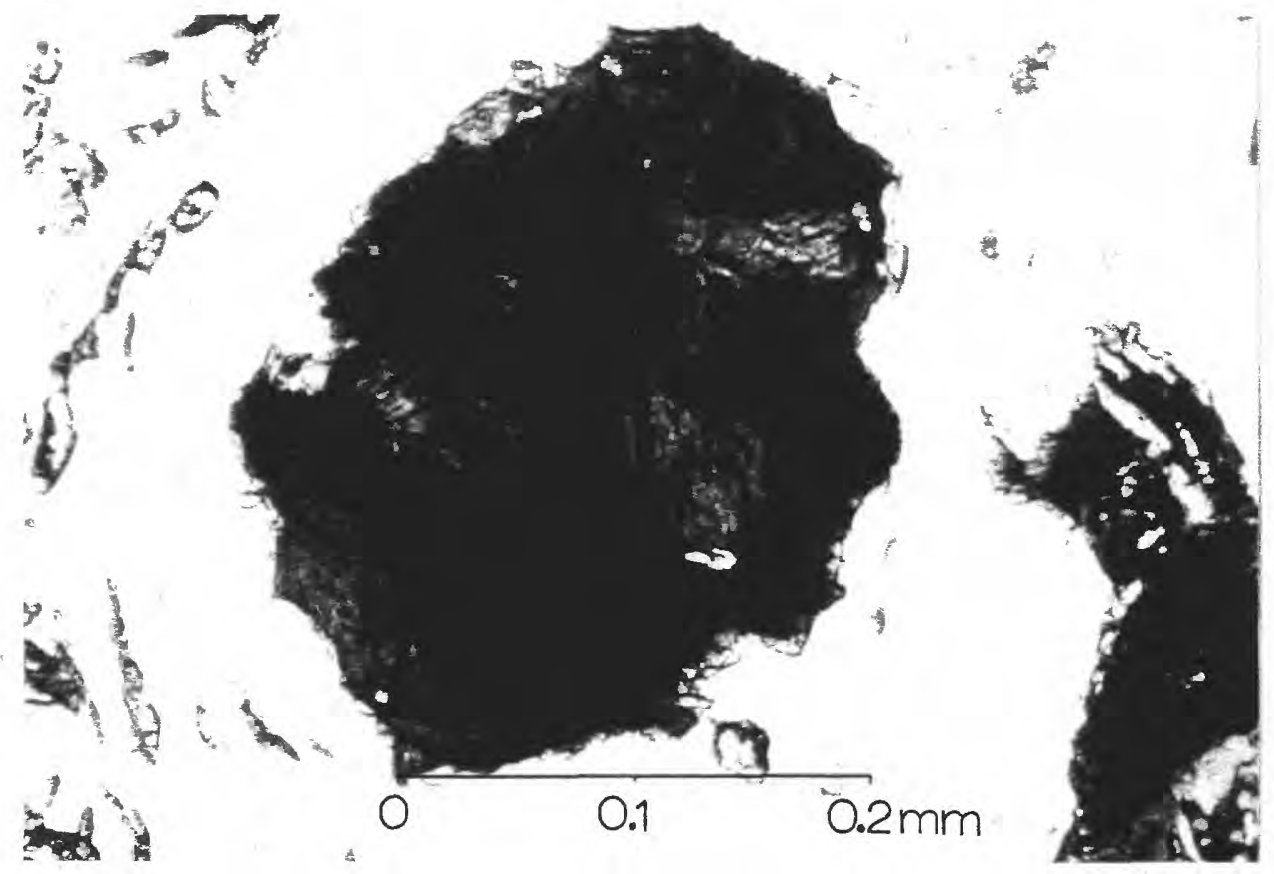

Figure 34. Chlorite pseudomorph of gamet in albite porphyroblast $($ syn-s2) in bgs-106. X-nicols. 


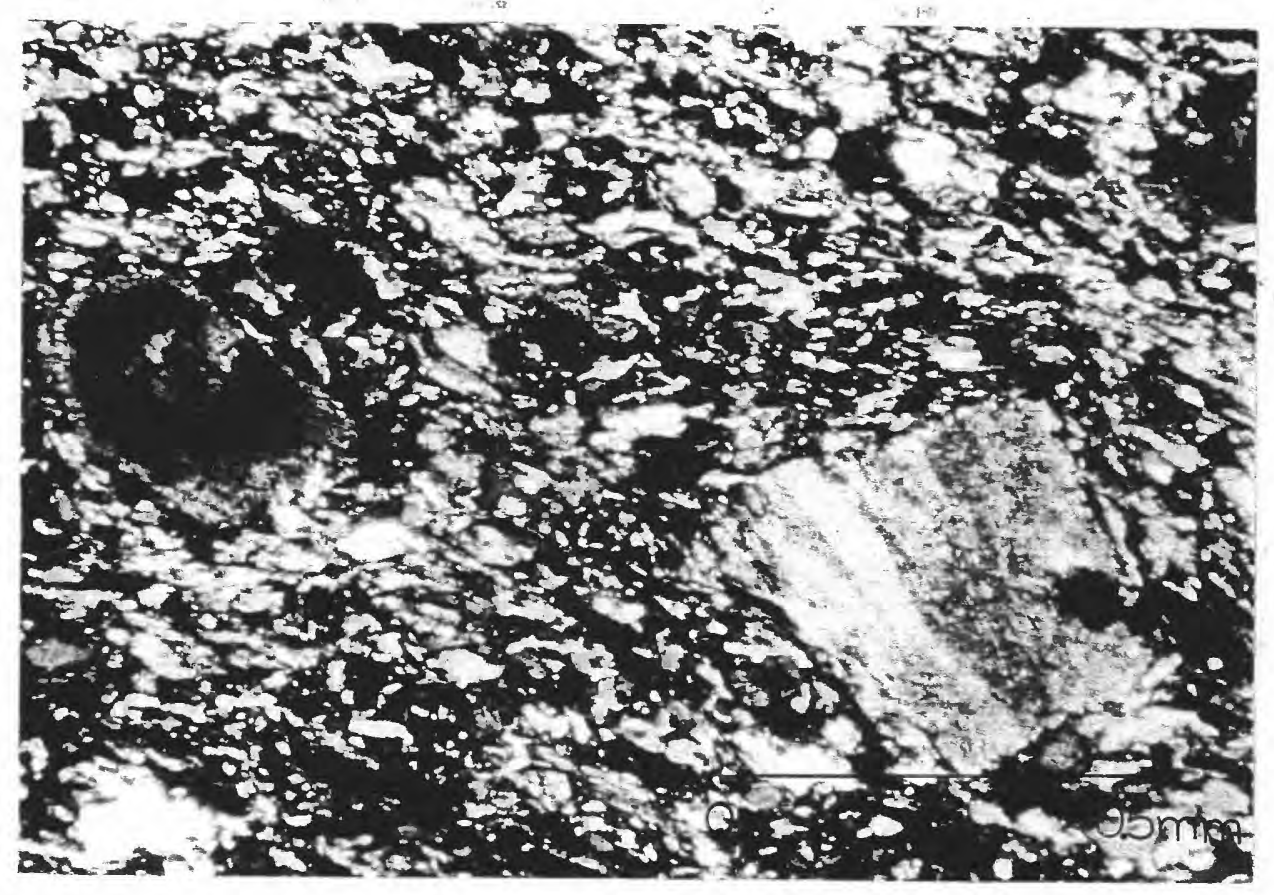

Figure 35. Fre-S2 epidote porphyroclast in bgs-208. X-nicols.

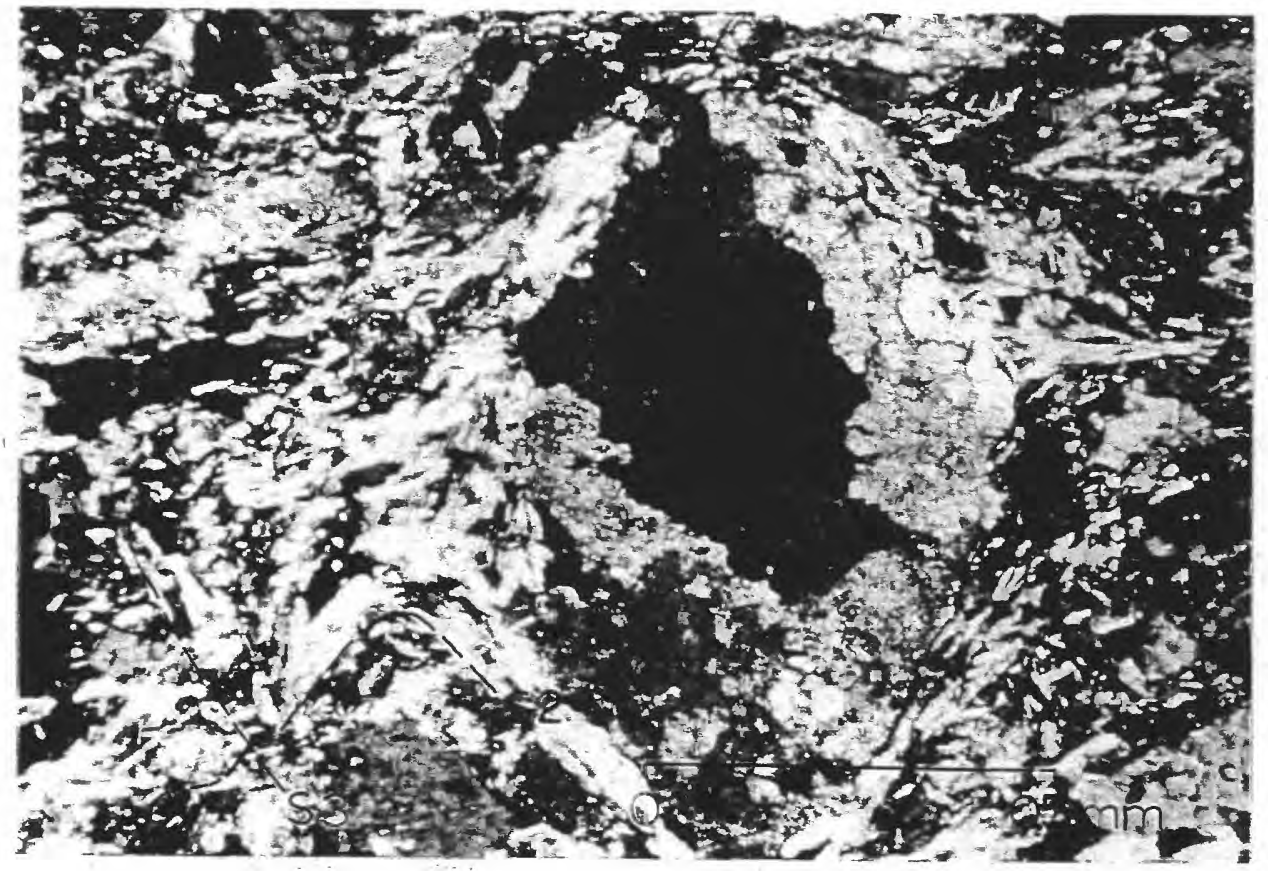

Figure 36. Fre-S2 epidote aggregate in bgs-190. X-nicols. 
mented, pressure fringes are present, and the matrix grains which define the S2 (S1?) foliation wrap around the epidote grains.

Where the S1 foliation is clearly distinguished from S2 (i.e., at F2 fold hinges), epidote-rich layers are parallel to and define S1. However, within the layers, the grains at the F2 fold hinges are aligned parallel to $\mathrm{S} 2$ and thus cross-cut the compositional layers (Figs. 37a, 37b, 37c). In most samples, S1 (compositional layers) is also parallel to $\mathrm{S} 2$, and differentiating mineral growth events is difficult.

Amphibole. The amount of amphibole in the greenstone varies - from zero to $63 \%$ (Table 3). Amphibole occurs as small, fibrous needles exhibiting pale yellow to pale green (z) pleochroism, and yellow birefringence. $Z^{\wedge} \mathrm{c}$ varies from $15^{\circ}$ to $18^{\circ}$. The amphibole is here referred to as actinolite.

Actinolite is in a fine grained mass with chlorite, oriented parallel to $S 2$ (and $S 1$ on F2 limbs). In sample 210, actinolite occurs in compositional bands which are parallel to $S 1$, although within the bands it is parallel to S2 at the F2 fold hinge (Figs. 37a, 37b, 37c). The actinolite needles are folded by the crenulate folds associated with F3. These relationships indicate two stages of actinolite growth: growth in compositional bands which define S1; growth as discrete, oriented grains paralle1 S2.

Tiny actinolite laths also occur as inclusion trains (parallel S1) in albite porphyroblasts (pre-syn F2). These laths are pleochroic in shades of pale green. In several samples $(200,208)$, large, anhedral, mottled, tan amphiboles (hornblende ?) with low bire- 


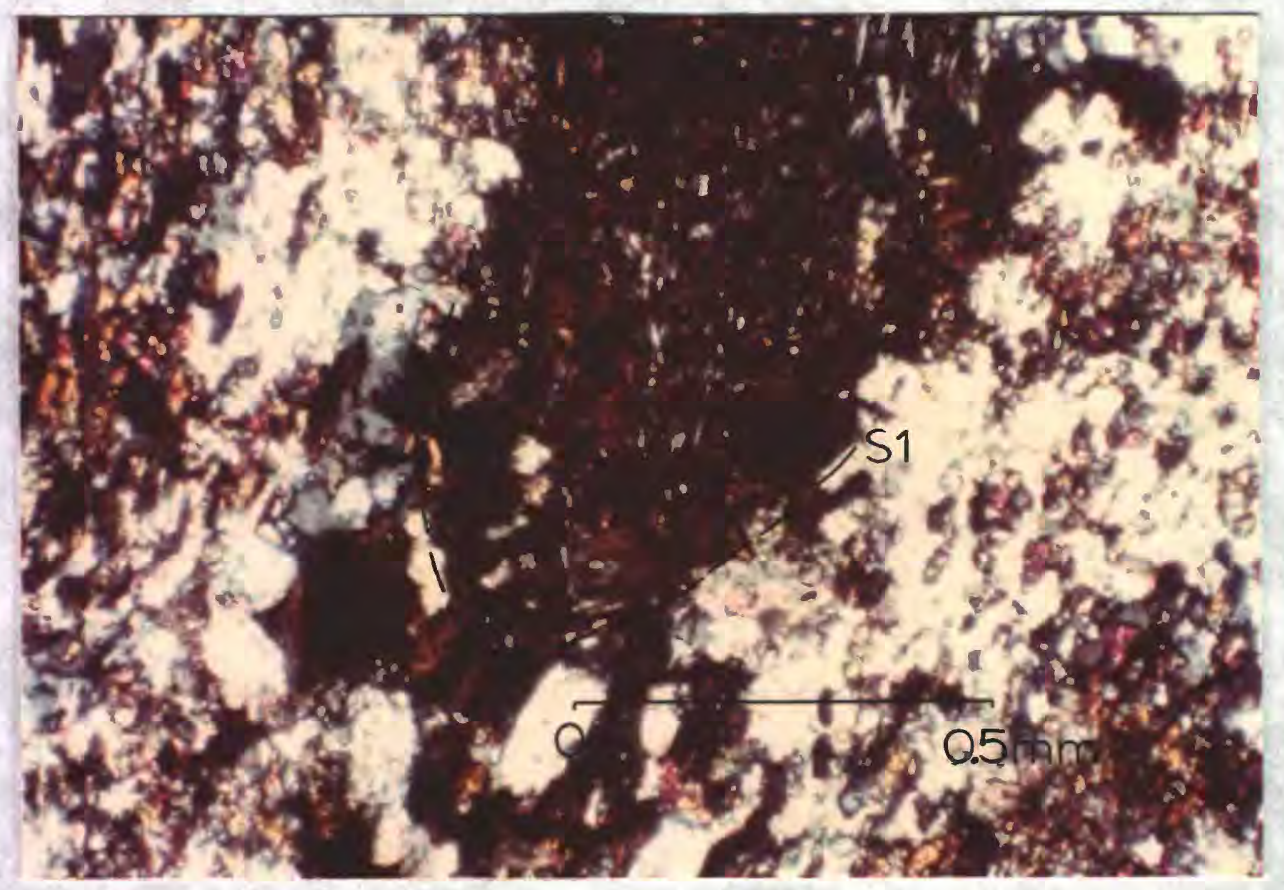

Figure 37a. F2 isoclinal fold of compositional bands (SI) in bgs -210 . X-nicols.

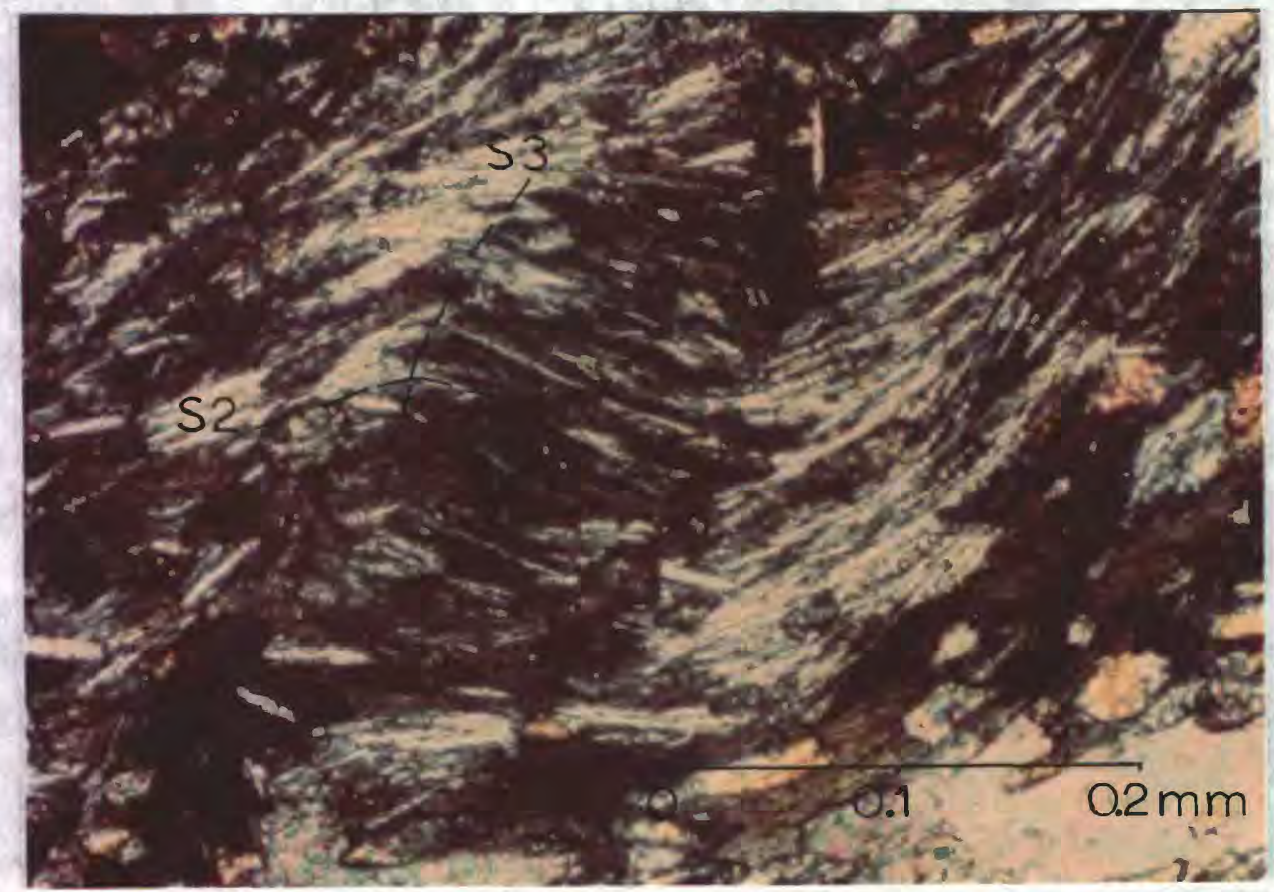

Figure 37b. Actinolite-chlorite rich band (Fig. 37a) parallel S1 with minerals aligned parallel to the F2 axial surface, and deformed by $\mathrm{F} 3 / \mathrm{S} 3$ in bgs-210. X-nicols. 


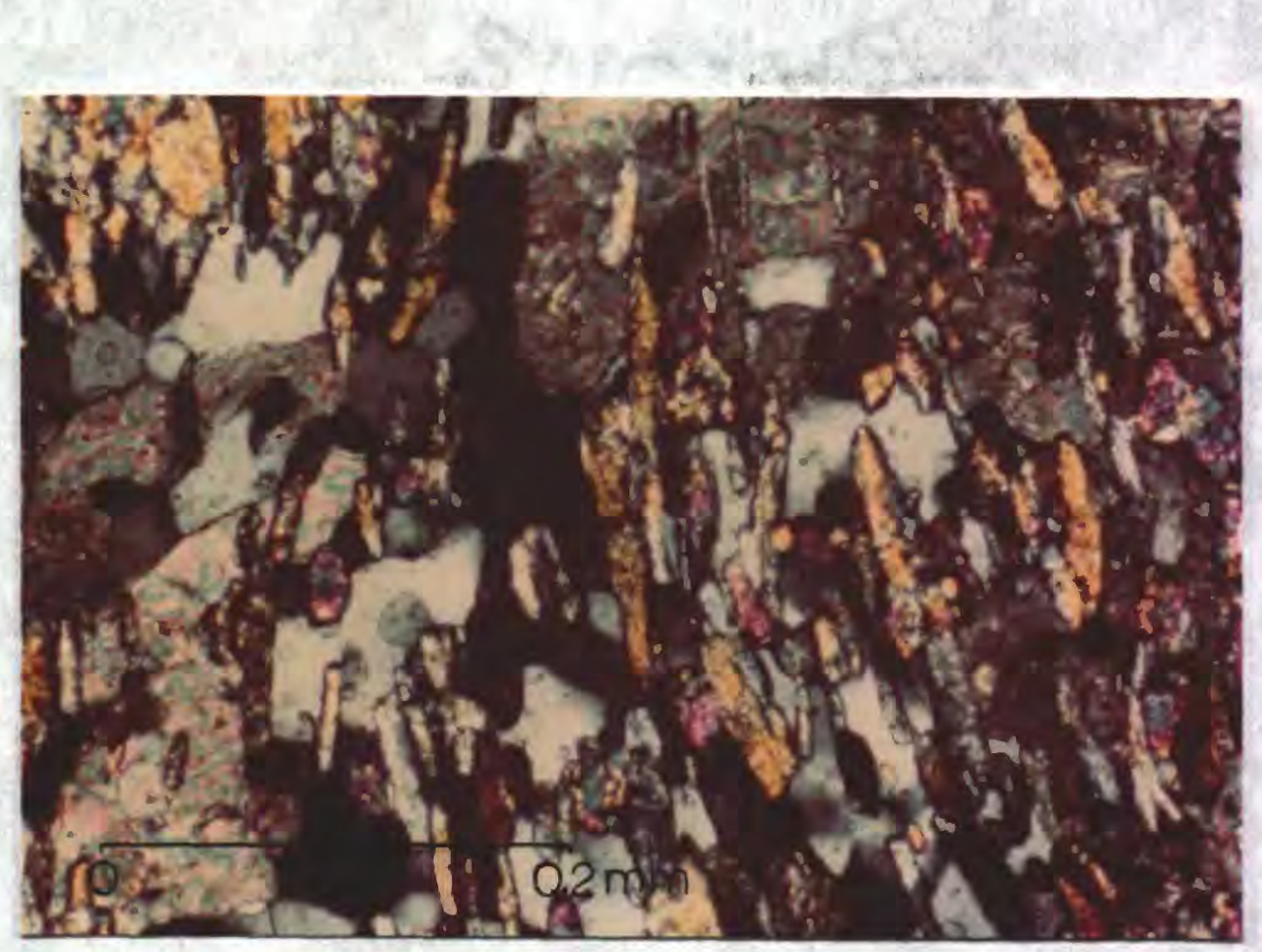

Figure 37c. Epidote aligned parallel to $\$ 2$ within calcitealbite-quartz-epidote band (parallel Sl) in bgs-210. X-nicols. 
fringence are present as porphyroclasts relative to the S2 (S1 ?) schistosity (Fig. '38).

Albite. Plagioclase feldspar comprises from $2 \%$ to $35 \%$ of the greenstone. The feldspar is nearly pure albite (Chidester et al., 1978). Albite occurs as interlocking anhedral grains, and as porphyroblasts with helicitic textures.

The anhedral grains occur in layers, as discrete grains, and in aggregates. In some samples, albite and calcite are intergrown (Fig. 39). Most of the albite grains are not twinned, although some grains exhibit either simple or multiple twins. The multiple twins ảre commonly faint and discontinuous, and frequently display several different orientations within a single grain. Some grains have twinned cores and untwinned rims. Many of the albite grains exhibit patchy extinction. The interlocking grains are commonly present in layers paralle1 to $\mathrm{S} 1$, and thus also parallel to $\mathrm{S} 2$ on the limbs of F2 folds. In sample 210 (Figs. 37a, 37b, 37c), interlocking grains of albite, calcite, and quartz define compositional bands parallel to S1 which are folded by $F 2$ isoclinal folds. In several samples, large anhedral albite grains are present as porphyroclasts in the finer grained albitic bands which define S1 (Fig. 40).

Albite also occurs as anhedral porphyroblasts exhibiting helicitic textures. The porphyroblasts are commonly elongate in the direction of S2, and are deformed by the F3 crenulate folds. The inclusions in the porphyroblasts are comprised of aligned epidote and actinolite. Chlorite, as a pseudomorph of garnet, also is present as inclusions in albite (Fig. 34). 


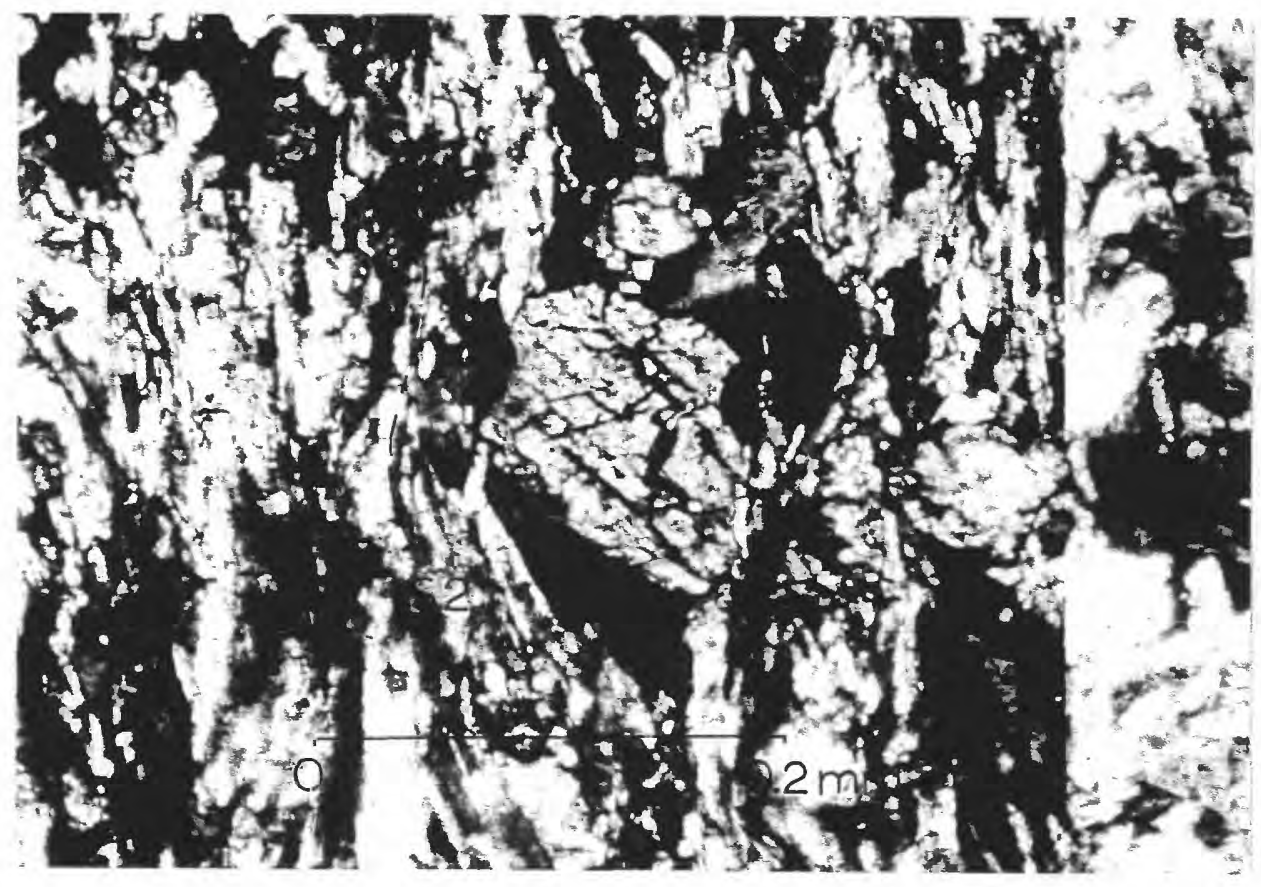

Figure 38. Pre-S2 amphibole porpinyroclast in bgs-314. X-nicols. iote the pressure fringe on lover part of clast and the wrapping of the S2 schistosjty around the amphibole.

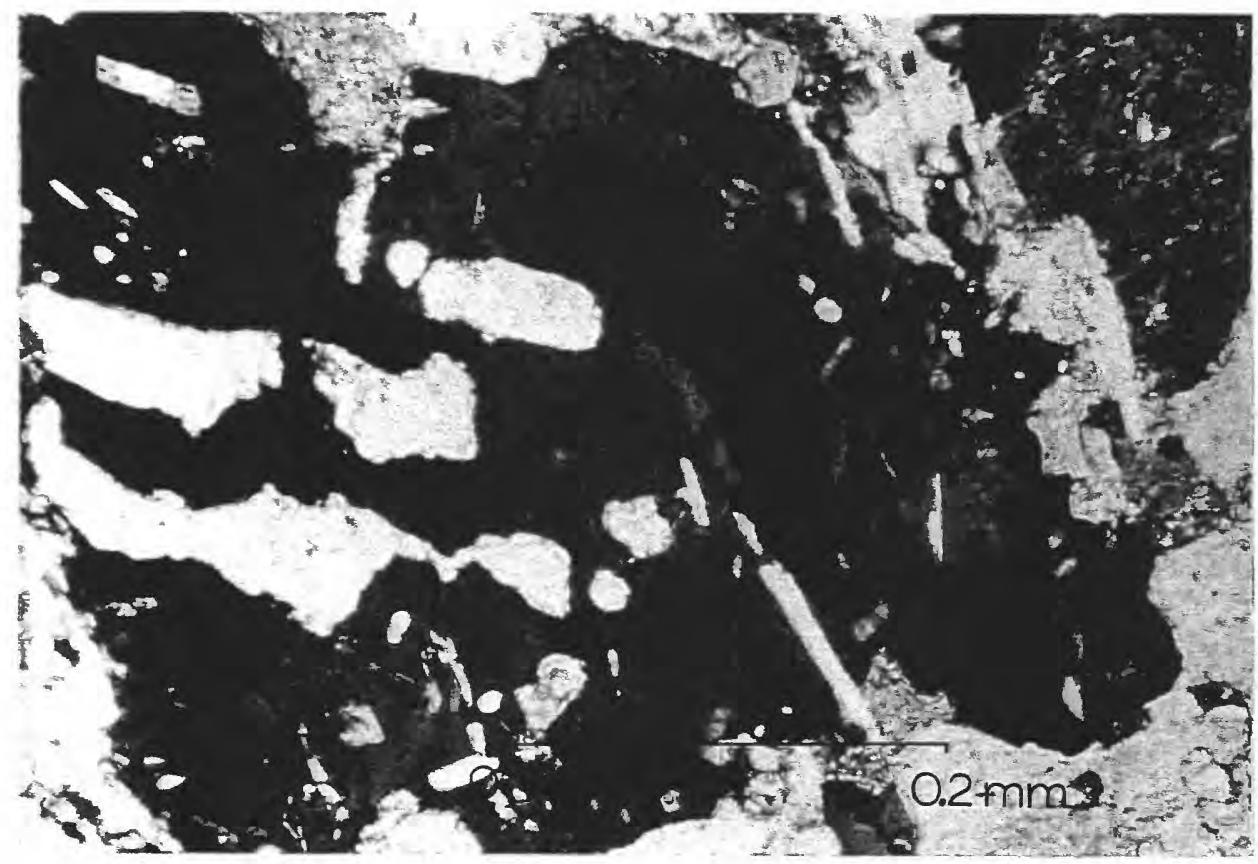

Figure 39. Aluite and calcite intergrown in bgs-190. X-nicols. 


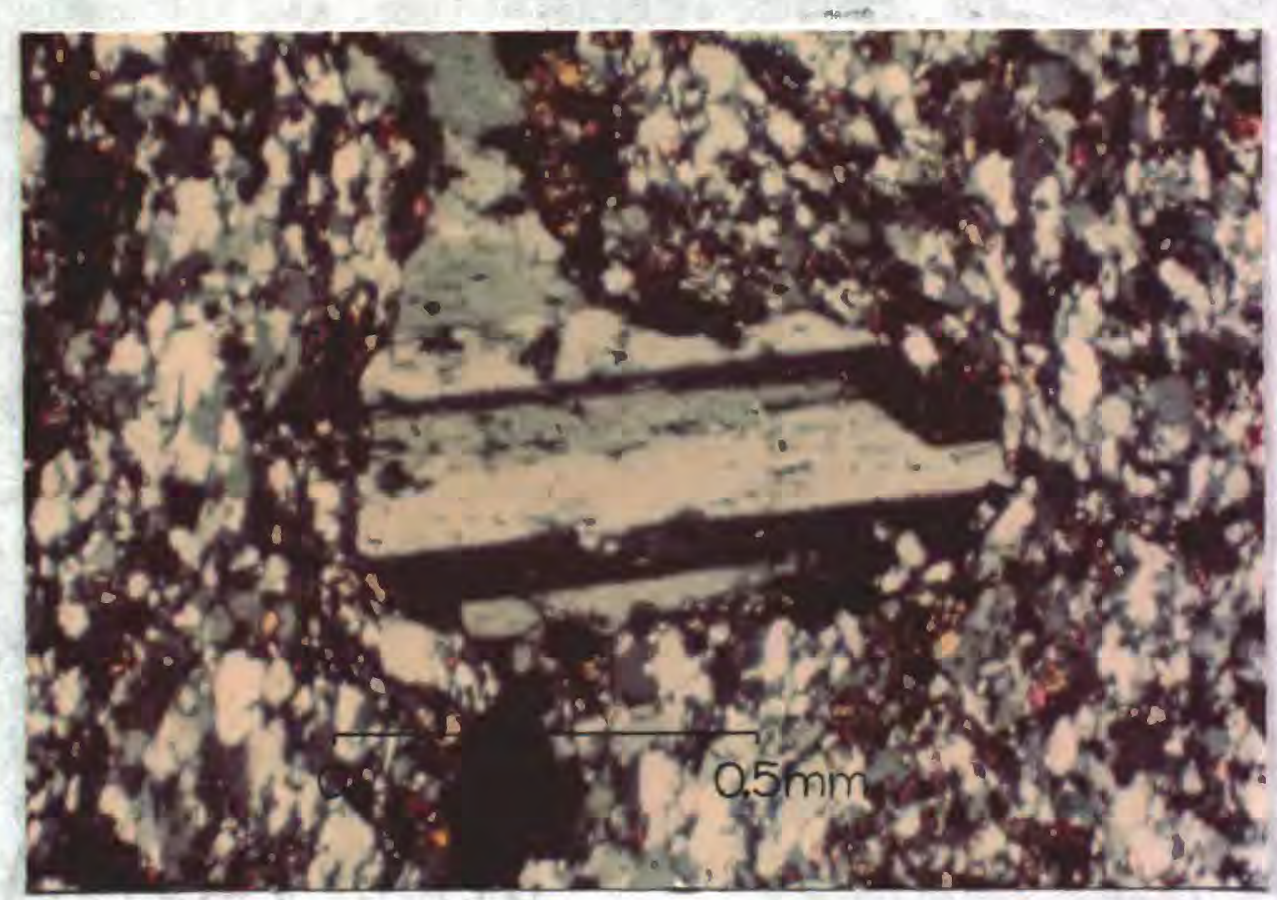

Figure 40. Twinned albite porphyroclast (pre-sl ?) in albite-quartz band (S1) in bgs-125. X-nicols. 
The textural relations between the inclusions in the porphyroblast and the matrix are variable. The inclusion trains may be either straight or folded. In some samples, the inclusions are at a high angle to the dominant S2 foliation in the rock which wraps around the porphyroblasts. Thus, the porphyroblasts appear as pre-S2, and record an earlier foliation (Fig. 41). However, in other grains the inclusions are continuous with matrix, thus suggesting syn- to post-F2 growth of the albite porphyroblasts (Fig. 42). Growth of albite porphyroblasts may therefore be post-F1 to syn-F2.

A three stage development of albite is suggested by the various textural relationships observed. Twinned albite porphyroclasts, within the finer grained albitic layers which define S1 (Fig. 40), suggest that the porphyroclasts are pre-S1. Interlocking grains which define the compositional layers associated with S1 represent a second stage of development, and may result from shearing and recrystallization of the pre-S1 albite grains. Albite porphyroblasts represent the final stage in the development of the albite textures observed. Some of the porphyroblasts have twinned cores and untwinned rims, some of the grains have "clean" cores and helicitic textures confined to the rims, and many of the porphyroblasts have a high variation in the twin orientation within a single grain. These relationships suggest two stages of growth of the porphyroblasts, and it is proposed that the post-FI porphyroblasts result from coalescence and recrystallization of numerous, discrete and interlocking grains associated with F1/S1.

Calcite. The amount of calcite in the greenstone varies from zero to 20 percent. Calcite occurs as discrete anhedral grains, as 


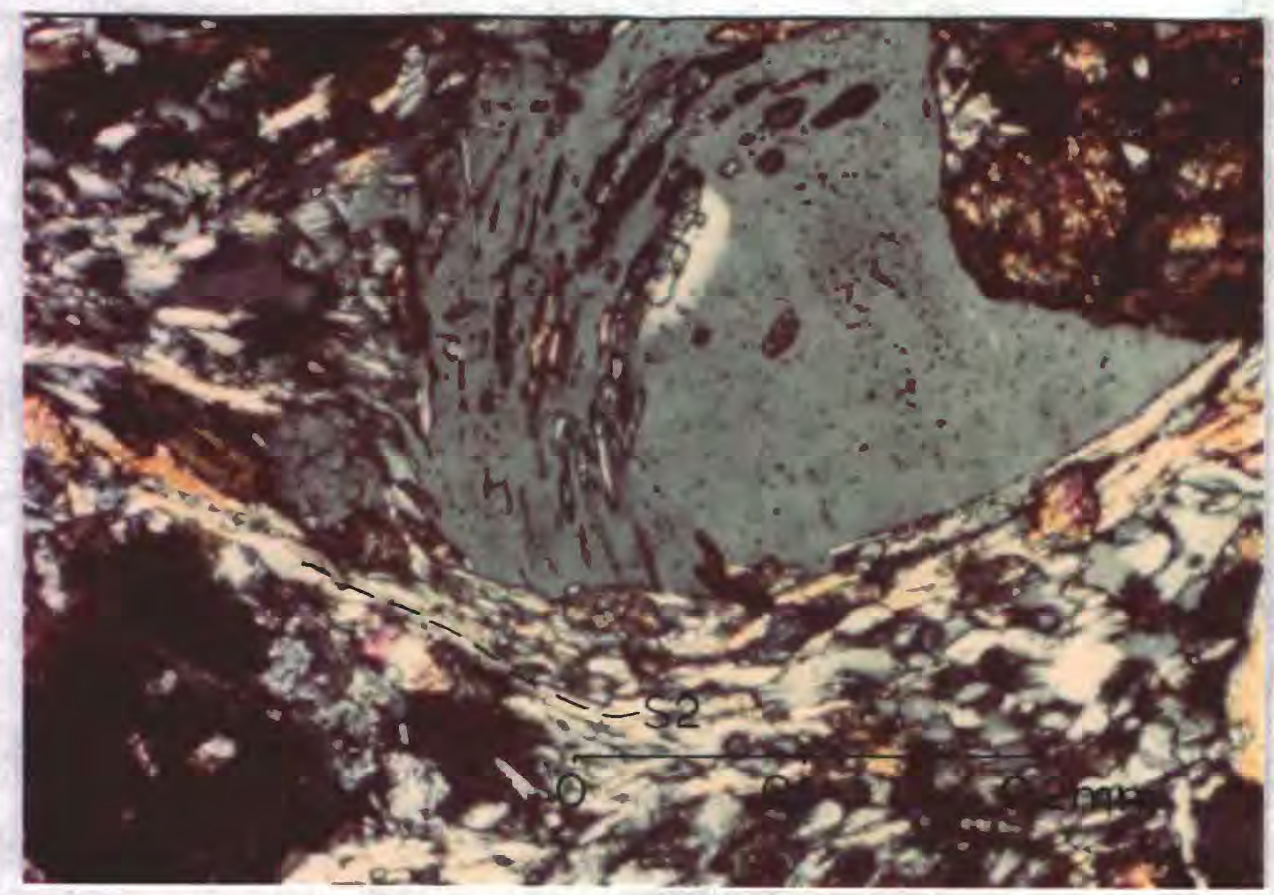

Figure 41. Helicitc texture (SI) in albite porphyroblast (syn-S2) in bgs-106. X-nicols.

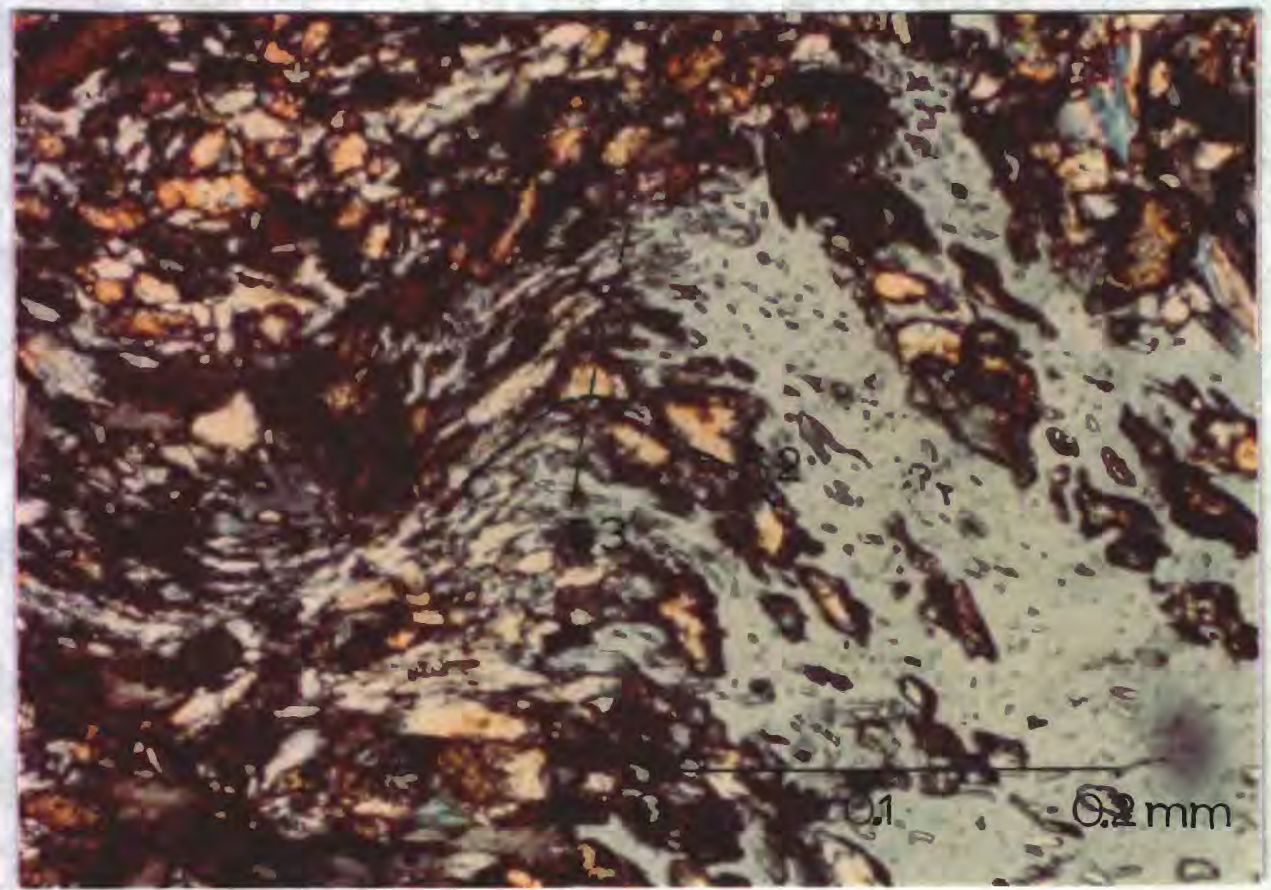

Figure 42. Inclusions in albite porphyroblast continuous with matrix grains (S2) in bgs-329. X-nicols. 
subhedral to anhedral interlocking grains in veins with quartz, and most commonly, in compositional layers with albite and quartz.

In several of the large anhedral grains, the twins are continuous through the grain, but the grains exhibit patchy extinction. Many of the large grains are fractured. A few of the smaller grains are confined to the crests and troughs of F3 crenulate folds.

Veins of calcite and quartz are parallel to the S2 foliation, and are deformed by F3 folds. Most of the veins are discontinuous, and in outcrop, some veins are folded by F2 suggesting that the veins actually paralle1 S1.

Calcite occurs with anhedral interlocking grains of albite in bands parallel to $S 1$. Calcite also occurs at the grain boundaries of albite, intergrown with albite, and in some cases completely surrounds albite. In sample 190, some of the albite grains have calcite cores.

Quartz. Quartz is present in only six of the samples studied, and the amount of quartz varies from zero to 10 percent. Quartz occurs as discontinuous veins with calcite, as recrystallized interlocking grains with triple point junctions, and as ribbon quartz. In thin section, the veins appear parallel to $S 2$ and $S 1$, although in outcrop the veins are folded by F2.

Biotite. The amount of biotite in the greenstone varies from zero to 5 percent (Table 3). Biotite occurs as anhedral plates, and as an intergrowth with chlorite.

Sphene. Sphene comprises from zero to 5.4 percent of the greenstone (Table 3). Sphene is present as distinct, subhedral to 
euhedral, homogeneous grains with high relief and strong birefringence. Some grains have black dusty rims. Sphene is commonly distributed in planes parallel to $\mathrm{S2}$, but also appears in random distribution.

Opaques. The percent of opaque minerals in the greenstone varies from zero to 2 percent. Subhedral to euhedral grains of pyrite and magnetite are the common opaque minerals in the greenstone. A deep red-brown dust is present along grain boundaries in some samples.

Summary. The relationship of mineral growth to deformation in the greenstone is summarized in Figure 43. Compositional layering in the greenstone is folded by F2 isoclinal folds. Thus, S1 and S2 are nearly parallel except at F2 fold hinges, and the exact separation of the mineralogy associated with these minor structures is difficult.

The compositional layering (S1) is composed mainly of alternating albite-calcite-epidote-quartz rich or albite-epidote rich layers and chlorite-actinolite rich layers. Therefore, this greenschist facies mineralogy is associated with S1/F1. A still earlier (early D1) epidote-amphibolite facies assemblage is indicated by porphyroclasts of epidote, albite, hornblende, and garnet (altered to chlorite) within the compositional layers. In addition to petrographic criteria, several field relationships indirectly support two D1 metamorphic events (epidote-amphibolite facies and greenschist facies) for the greenstone. Firstly, fragments of greenstone and amphibolite are present in the muscovite schist (mus), suggesting that both epidote-amphibolite facies and greenschist facies metamorphism pre-dates the incorporation of these mafic rocks in the schist. The schist is subsequently deformed by folds and faulting still associated 
Figure 43. Mineral growth and deformation.

\begin{tabular}{|c|c|c|c|c|c|}
\hline \multirow{3}{*}{$\begin{array}{l}\text { Greenstone, bgs } \\
\text { Albite } \\
\end{array}$} & \multicolumn{3}{|c|}{$\overline{\mathrm{F} 2}$} & \multirow[t]{2}{*}{ F3 } & \multirow[t]{2}{*}{ F4 } \\
\hline & pre" & syn & post & & \\
\hline & $?$ & & $-\cdots ?$ & & \\
\hline Albite porphyroblasts & $?----$ & & $----?$ & & \\
\hline Actinolite & $?-$ & & $----?$ & & \\
\hline Amphibole* & $----?-$ & $\ldots \ldots-\ldots$ & & & \\
\hline Biotite & $?---$ & & $-\cdots--?$ & & \\
\hline Calcite & $?-\ldots$ & & $\ldots-\cdots$ & & \\
\hline Chlorite & $?-$ & & $----?$ & & \\
\hline Epidote & $?-$ & & $-\cdots ?$ & & \\
\hline Garnet & $?=$ & & & & \\
\hline Quartz & $?-$ & & $----?$ & & \\
\hline Sphene & $?---$ & & $-\cdots--?$ & & \\
\hline Opaques & $?---$ & $-\cdots-n-n$ & $---?$ & & \\
\hline
\end{tabular}

": Relationship to F1 (i.e., pre, syn, post) not accurately defined.

*: Mottled amphibole fragments, pleochroic in tan and olive green (hornblende). 
with D1. Secondly, thin $(<3 \mathrm{~mm})$, discontinuous lenses of amphibolite occur in the greenstone (Plate II, Loc. 91), suggesting possible derivation of the greenstone by shearing and recrystallization of an amphibolite. Lastly, in the field, the coarse grained amphibolite, fine grained amphibolite, and greenstone appear gradationa1, although the fine grained amphibolite contact(s) with the greenstone are fault contacts.

At F2 fold hinges, actinolite, chlorite, and epidote are oriented nearly perpendicular to the compositional layering, and thus are parallel to and define S2. Elongate albite porphyroblasts are paralle1 to $\mathrm{S} 2$ and are nowhere deformed by F2. Thus, greenschist facies metamorphism is also associated with F2/S2. No change in the metamorphic assemblage is associated with the F3 and F4 fold deformations.

The expected mineral assemblages for the greenstone are shown on an ACF diagram in Figure 44. The ACF diagram was constructed following the outline of Winkler (1967). Corrections were made for sphene, ilmenite, and magnetite. The mineral assemblage in the greenstone is: actinolite-albite-epidote-chlorite \pm calcite \pm quartz \pm sphene \pm sericite \pm biotite \pm opaque. This assemblage is in the greenschist facies of the medium pressure type as defined by Miyashiro (1973, p. 306) and the quartz-albite-epidote-biotite subfacies of the greenschist facies as defined by Winkler (1967, p. 100). The expected . mineral assemblages are also represented diagrammatically on an $\mathrm{Na}_{2} \mathrm{O}-\mathrm{AF}_{2} \mathrm{O}_{3}-\mathrm{CaO}-\mathrm{FMO}$ tetrahedron (Fig. 45) for the biotite-albite zone of the medium pressure facies series as discussed by Laird (1977). 


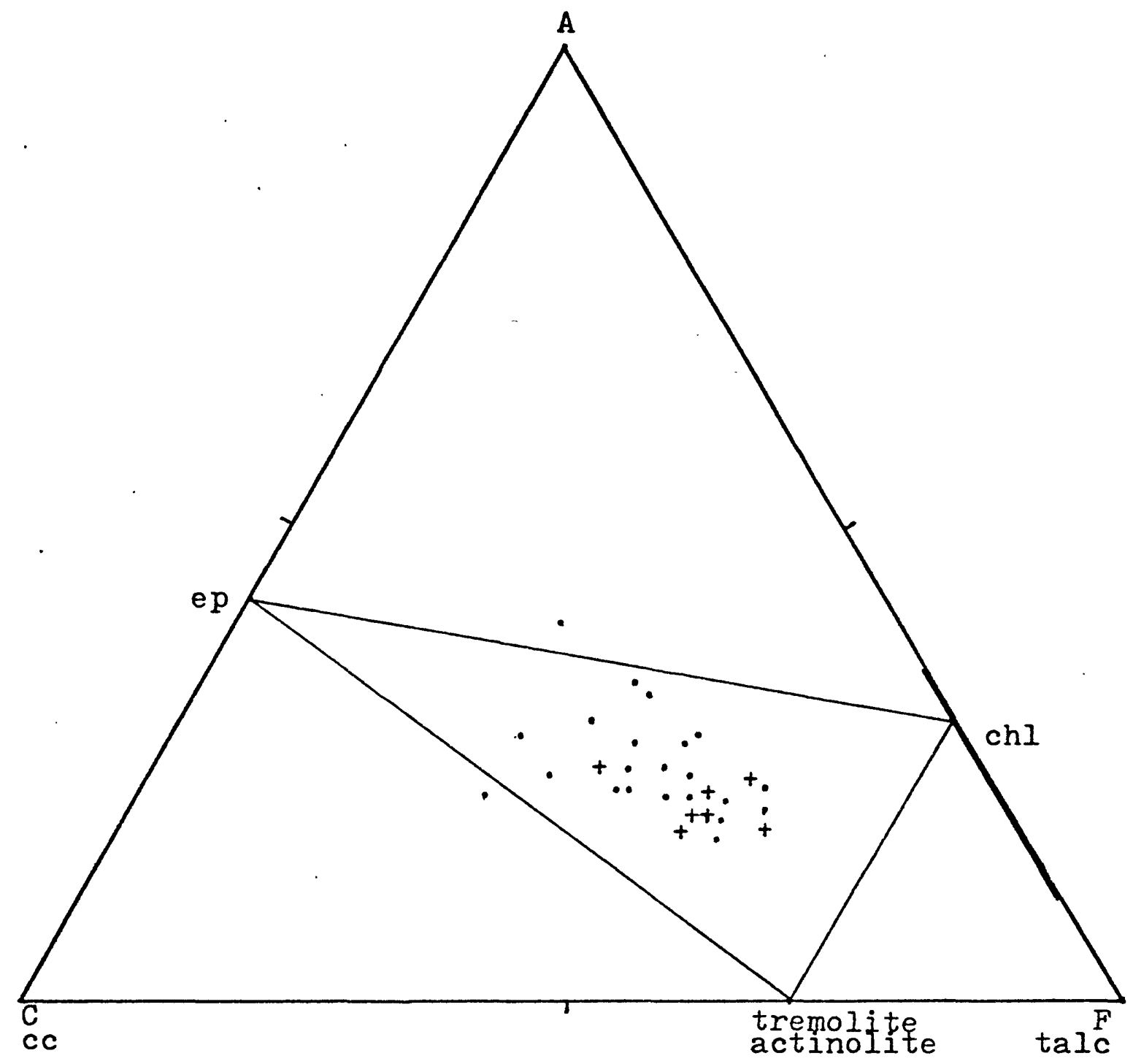

Figure 44. ACF diagram for the greenstone ( $\cdot)$ and amphibolites ( + ). $\mathrm{A}=\mathrm{Al}_{2} \mathrm{O}_{3}+\mathrm{Fe}_{2} \mathrm{O}_{3}-\left(\mathrm{Na}_{2} \mathrm{O}+\mathrm{K}_{2} \mathrm{O}\right) ; \mathrm{C}=\mathrm{CaO}-3.3 \mathrm{P}_{2} \mathrm{O}_{5} ; \mathrm{F}=\mathrm{FeO}+\mathrm{MgO}+\mathrm{MnO}$. Values corrected for magnetite, ilmenite, and sphene, and expressed in molecular percent. 


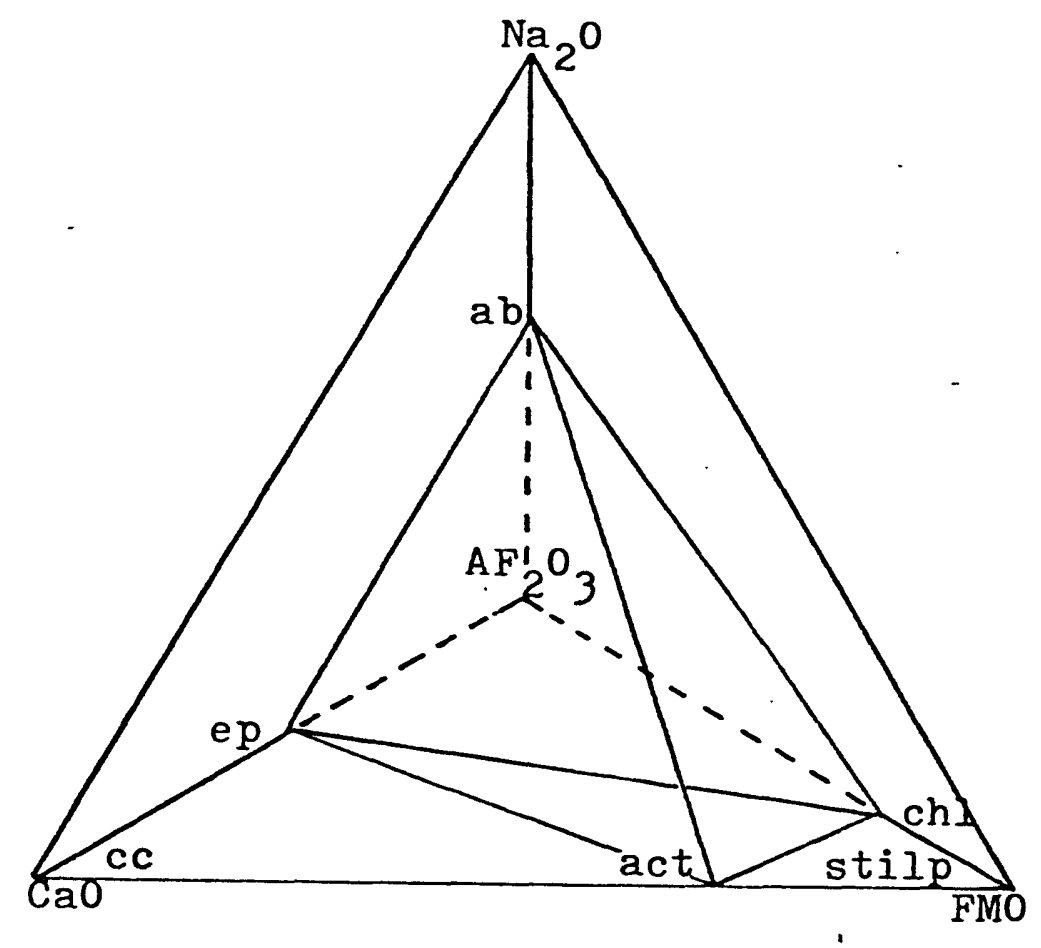

Figure 45. $\mathrm{Na}_{2} \mathrm{O}-\mathrm{AF}_{2} \mathrm{O}_{3}\left(\mathrm{Al}_{2} \mathrm{O}_{3}+\mathrm{Fe}_{2} \mathrm{O}_{3}\right)-\mathrm{CaO}-\mathrm{FMO}(\mathrm{FeO}+\mathrm{MgO}+\mathrm{MnO})$ tetrahedron for the biotite-albite zone of the medium pressure type (from Laird, 1977, p. 428). 
Fine Grained Amphibolite, baf

The amphibolite is a fine to medium grained, dark gray-green rock composed of varying amounts of amphibole, albite, epidote, chlorite, garnet, sphene, biotite, quartz, and opaque minerals (Table 4). The parallelism of actinolite, glaucophane, chlorite, epidote, and elongate albite porphyroblasts defines the dominant S2 schistosity. The earlier $\mathrm{Sl}$ foliation is defined by fractured, fragmented grains of hornblende and epidote. Garnet, exhibiting partial to complete alteration to chlorite and albite, also pre-dates the S2 schistosity.

Amphibole. The amount of amphibole in the fine grained amphibolite varies from $20.4 \%$ to $63 \%$. Three different amphiboles are present in the amphibolite: hornblende; actinolite; glaucophane. Anhedral to subhedral laths, pleochroic in $\tan (x)$ to pale blue $(y)$ to green (z) are here referred to as hornblende. Some of the hornblende laths are zoned, with the core exhibiting blue-green $(y)$ to olive green (z) pleochroism. Glaucophane here refers to amphibole which exhibits colorless $(x)$ to pale blue $(y)$ to green blue $(z)$ pleochroism, and has an estimated $2 \mathrm{~V}$ of 50-60. This amphibole is optically the same as "blue" amphibole from Tillotsen Peak. Laird (1977), based on microprobe analyses, identified the "blue" amphibole at Tillotsen Peak as glaucophane. Actinolite here refers to amphibole pleochroic in shades of pale green. Actinolite and glaucophane are parallel to the dominant S2 foliation which is deformed by F3 crenulate folds. Hornblende is associated with D1/S1.

Hornblende commonly occurs as fractured, fragmented grains, partially altered to chlorite and biotite. Hornblende is also present as porphyroclasts in a very fine matrix of chlorite, actinolite, 


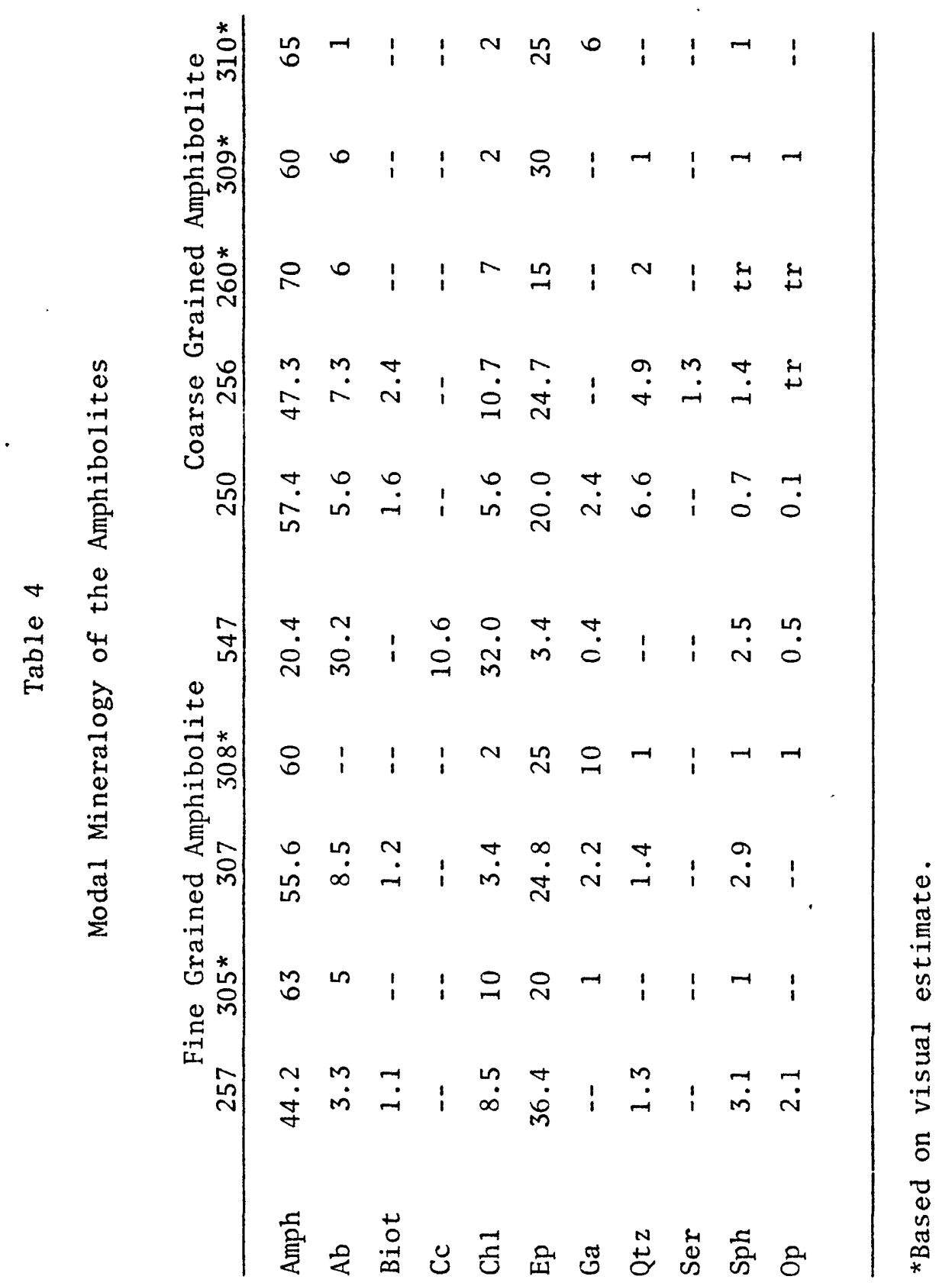


albite, and epidote which are parallel to S2. In some samples, hornblende laths are aligned at a high angle to the S2 schistosity, and define Sl (Fig. 46) .

Actinolite occurs as fibrous needles and as slightly larger distinct laths. The needles occur in a fine grained mass with chlorite, biotite, albite, and epidote, and are aligned parallel to S2. The S2 foliation wraps around the earlier hornblende and garnet grains (Fig. 47). Actinolite is also present as inclusions in albite porphyroblasts (syn-S2).

Subhedral to anhedral glaucophane laths occur sporadically, but where present, glaucophane is associated with actinolite laths, and the two amphiboles are parallel to 52 .

Albite. The amount of albite in the fine grained amphibolite varies from zero to 30.2 percent. Albite occurs as anhedral interlocking grains, and less commonly as poor to well developed porphyroblasts with inclusions of garnet (partially altered to chlorite), actinolite, epidote, and biotite. Albite porphyroblasts exhibit faint, discontinuous twins, and have patchy extinction. The porphyroblasts are elongate paralle1 to S2, and are deformed by F3 crenulate folds. Interlocking grains of albite occur as a rim on garnet, thus separating garnet and hornblende. The grains also occur as a fracture filling with chlorite and biotite along fractures in the garnet porphyroblasts. Albite is also present as distinct anhedral grains.

Epidote. Epidote comprises from $2.4 \%$ to $36.4 \%$ of the fine grained amphibolite (Table 4). Epidote is present as distinct, anhedral to subhedral colorless grains with high relief. Most grains 


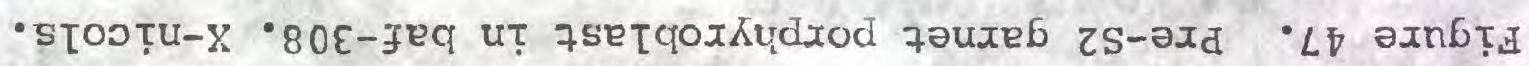

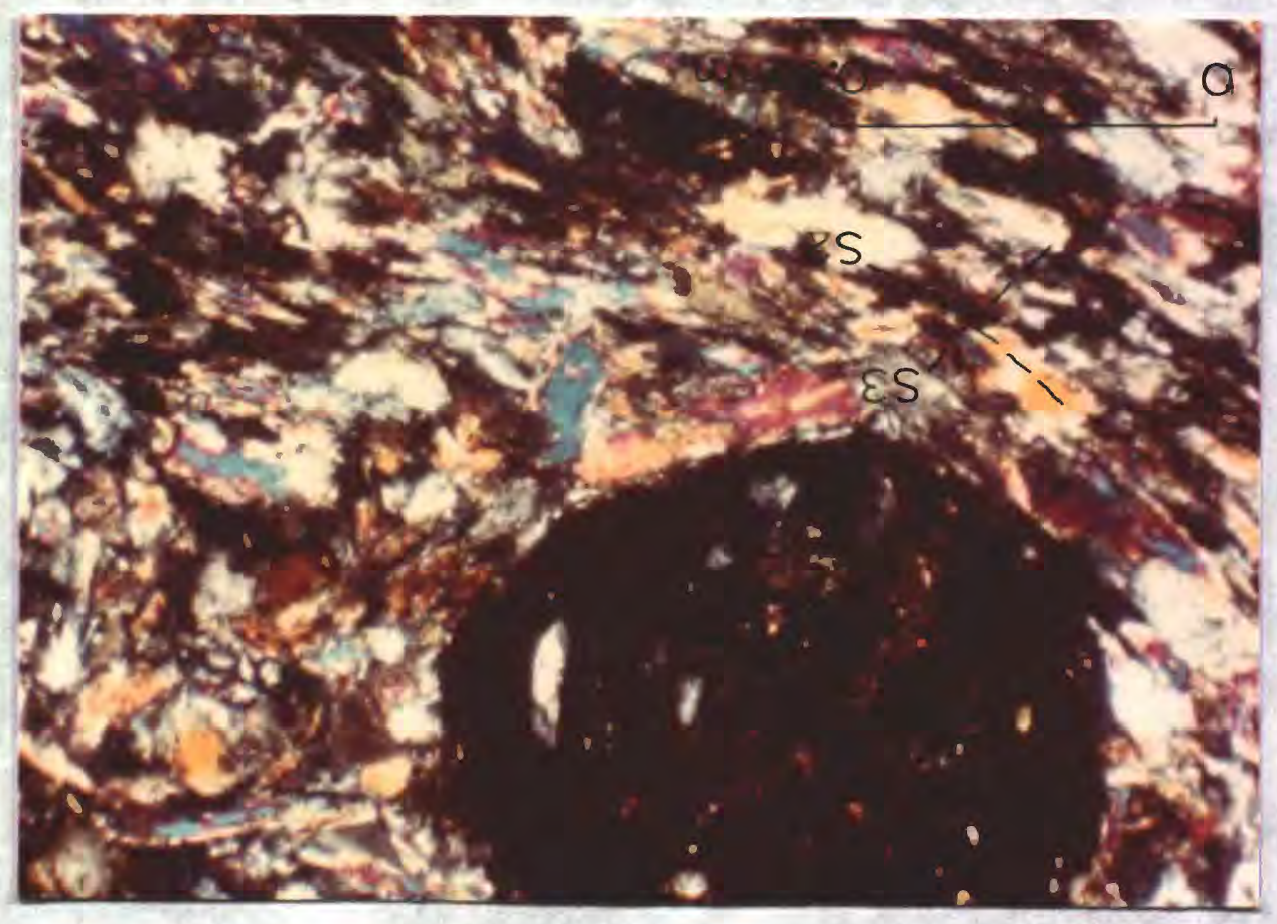

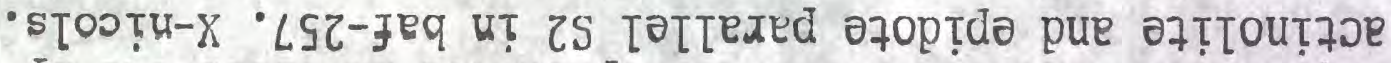

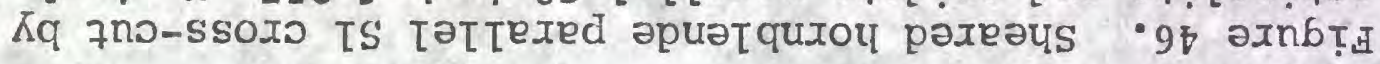

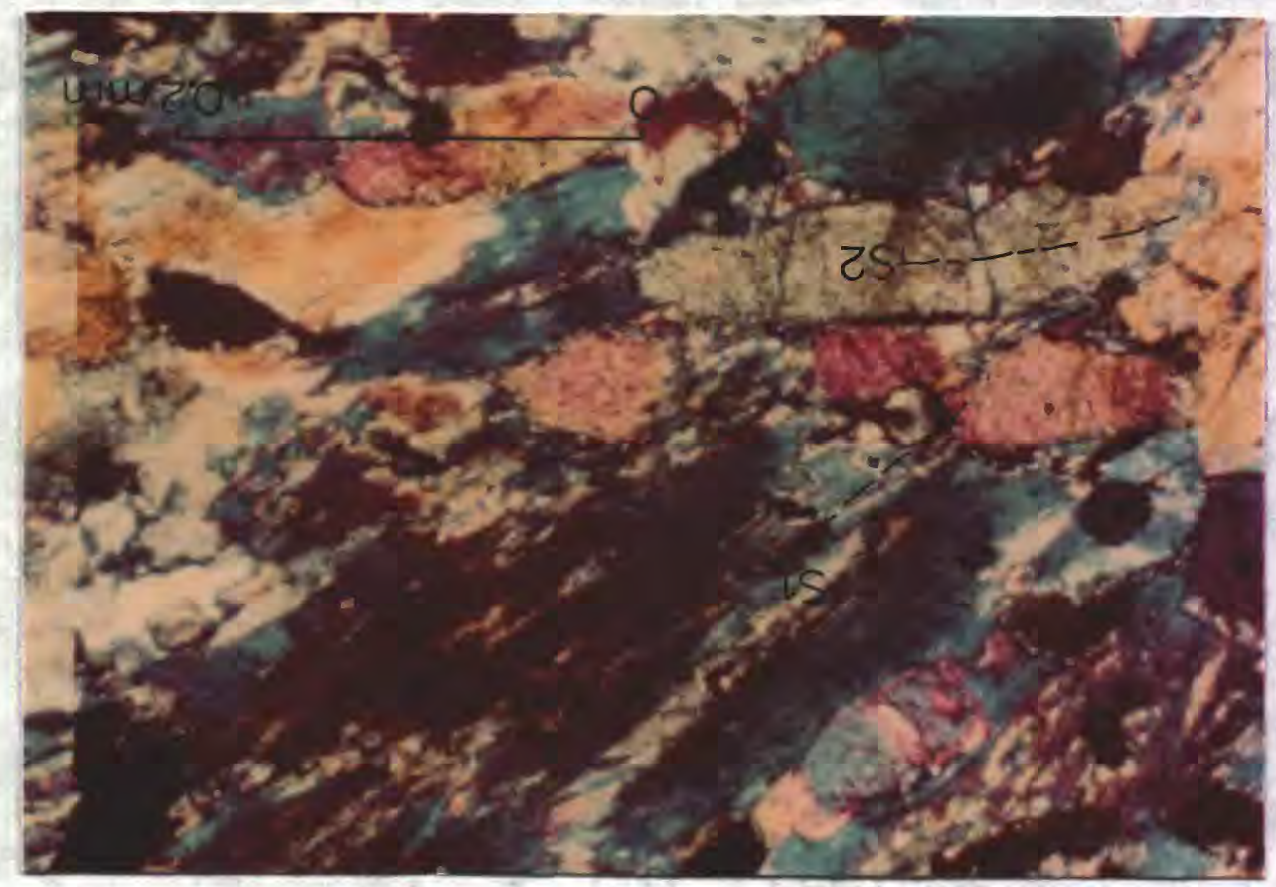


are not zoned although some grains with the cores exhibiting either higher or lower birefringence than the rims do occur.

Epidote is distributed in planes parallel to $\mathrm{S} 2$ which truncate the large anhedral hornblende laths (Fig. 46). In one sample (baf257), epidote occurs with hornblende as large fractured grains in a fine grained matrix of chlorite, albite, and biotite. These large grains (porphyroclasts) define a faint foliation (S1) which pre-dates S2. Thus, epidote is associated with both S1 and S2.

Chlorite. The amount of chlorite in the fine grained amphibolite varies from $2 \%$ to $32 \%$. Chlorite occurs as blades interleaved with actinolite and biotite, as scaly aggregates, as discrete anhedral plates, and as an alteration of garnet and hornblende.

Garnet. Garnet comprises from zero to 10 percent of the fine grained amphibolite. Garnet occurs as subhedral to euhedral porphyroblasts (porphyroclasts relative to S2), many with epidote inclusions. Some garnets are fractured, with albite, chlorite, and biotite present as fracture fillings. Many of the garnet porphyroblasts are partially altered to chlorite.

Small, euhedral garnets are present as inclusions in albite porphyroblasts. Garnet pre-dates the actinolite and glaucophane associated with F2/S2. However, the garnet porphyroblasts have inclusions of epidote, and rimmed by albite, they impinge upon the hornblende laths associated with S1. Thus, although garnet is associated with $\mathrm{S1}$, it appears to record late $\mathrm{S1}$ growth.

Calcite. Calcite comprises from zero to 10.6 percent of the fine grained amphibolite. Calcite is present as clusters of inter- 
locking grains, and with albite and chlorite along fractures in garnet.

Sphene. Discrete, subhedral to euhedral grains of sphene comprise from $1 \%$ to $3.1 \%$ of the fine grained amphibolite. Some grains have black, dusty rims. The grains are randomly distributed throughout the sample.

Biotite. Biotite comprises from zero to 1.2 percent of the fine grained amphibolite. Biotite occurs as an alteration of garnet and along cleavage planes in hornblende. In some samples, biotite is intergrown with chlorite.

Quartz. Quartz is present as anhedral interlocking grains with triple point junctions and as ribbon quartz. Quartz comprises from zero to $1.4 \%$ of the fine grained amphibolite.

Opaques. A black opaque dust is present along grain boundaries, especially at sphene boundaries. Opaques vary from zero to $2 \%$. Chidester et al. (1978) report the sporadic occurrence of magnetite, although it is not present in any of the thin sections used in this study.

Fine grained amphibolite--summary. The relationship of mineral growth to deformation for the fine grained amphibolite is summarized in Figure 48. The metamorphism associate: nith F2 is characterized by alteration of hornblende to chlorita, growth of actinolite and glaucophane, the pre- to syn-F2 alteration of garnet to chlorite, albite and calcite, syn- to post-F2 growth of albite porphyroblasts, and the growth of epidote in thin bands parallel to S2. 
Figure 48. Mineral growth and deformation of the amphibolites.

\begin{tabular}{|c|c|c|c|c|c|c|c|}
\hline \multirow[b]{2}{*}{ Baf } & \multicolumn{2}{|c|}{$\overline{F I}$} & \multirow{2}{*}{$\begin{array}{l}\text { pre/ } \\
\text { post }\end{array}$} & \multicolumn{2}{|c|}{ F2 } & \multirow[t]{2}{*}{ F3 } & \multirow[t]{2}{*}{ F4 } \\
\hline & pre & syn & & syn & post & & \\
\hline Albite & $?---$ & & $\ldots-\cdots$ & & $---?$ & & \\
\hline Albite porph. & & & $?--$ & & $---?$ & & \\
\hline Hornblende (1) & $?--$ & & $--?$ & & & & \\
\hline Amph (2) & & & $?--$ & & $---?$ & & \\
\hline Biotite & & & $?--$ & & $---?$ & & \\
\hline Calcite & & & $?--$ & & $---?$ & & \\
\hline Chlorite & & & $?--$ & & $---?$ & & \\
\hline Epidote & $?---$ & & $\ldots$ & & $---?$ & & \\
\hline Garnet & $?---$ & & $--?$ & & & & \\
\hline Quartz & $?---$ & & $-\cdots-\cdots$ & & $---?$ & & \\
\hline Sphene & $?---$ & 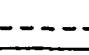 & $\ldots \ldots$ & & $---?$ & & \\
\hline Opaques & $?---$ & & $\ldots-\cdots$ & - & $---?$ & & \\
\hline \multicolumn{8}{|l|}{$\mathrm{Bac}$} \\
\hline Albite & $?---$ & & $\ldots-\cdots$ & & $---?$ & & \\
\hline Hornblende (3) & $?--$ & & $--?$ & & & & \\
\hline Actinolite (4) & & & $?---$ & & $---?$ & & \\
\hline Biotite & & & $?--$ & & $---?$ & & \\
\hline Chlorite & & & $?--$ & & $---?$ & & \\
\hline Epidote & $?---$ & & $-\ldots-\cdots$ & & $---?$ & & \\
\hline Garnet & $?---$ & & -- ? & & & & \\
\hline Quartz & $?--$ & 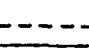 & $\ldots \ldots$ & & $---?$ & & \\
\hline Sphene & $?---$ & & -- & --- & $---?$ & & \\
\hline Opaques & $?---$ & $-\ldots$ & $-\ldots--$ & $-\cdots-\cdots$ & $---?$ & & \\
\hline
\end{tabular}

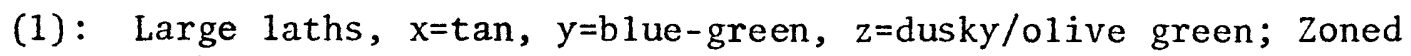
laths, $x=\tan , y=p a l e$ blue-green, $z=$ green, cores pleochoic in blue-green $(y)$ to olive green $(z)$.

(2): Actinolite, pleochroic in pale greens; Glaucophane (?), $x=$ colorless, $y=p a l e ~ b l u e, ~ z=$ green-blue.

(3): Zoned laths, rim pleochoic in pale greens, core pleochroic in light $\tan (x)$ to blue-green $(y)$ to olive green $(z)$.

(4): Fibrous laths pleochroic in pale greens. 
Hornblende laths define an early lineation associated with F1. Epidote and garnet occur as porphyroblasts which pre-date S2, and are thus also associated with hornblende. The cores of zoned hornblende may be evidence of a still earlier metamorphism.

In the fine grained amphibolite, the metamorphism associated with the F2 deformation is less severe than in the greenstone, in that more of the early phases (epidote-amphibolite facies assemblage) and evidence of pre-F2 textures are preserved. Textural variations in the fine grained amphibolite include: predominantly an Fl fabric with discrete shear surfaces along which minerals are bent, broken, and granulated (baf-275); predominantly an F2 fabric in which only a few grains from the earlier events are preserved as porphyroclasts, and which is similar to the textures in the greenstone (baf-547).

The expected mineral assemblages for the fine grained amphibolite are shown on ACF diagrams in Figures 44 and 49 . The mineralogy associated with the F2 deformation is: actinolite-chlorite-epidote \pm albite \pm "blue" amphibole \pm calcite \pm quartz \pm biotite \pm sphene \pm opaques. This assemblage is in the greenschist facies as defined by Miyashiro (1973) and in the quartz-albite-epidote-biotite subfacies of the greenschist facies as defined by Winkler (1967). The presence of glaucophane in some samples may indicate slightly higher pressures than the typical Barrovian greenschist facies (Winkler, 1967). The assemblage may thus be more aptly represented on the $\mathrm{Na}_{2} \mathrm{O}-\mathrm{AF}_{2} \mathrm{O}_{3}-\mathrm{CaO}-$ FMO tetrahedron (Fig. 50) for the medium to high pressure facies series as discussed by Laird (1977). Therefore, the conditions of metamorphism may best be defined by the higher pressure, lower temperature area in the greenschist facies. 


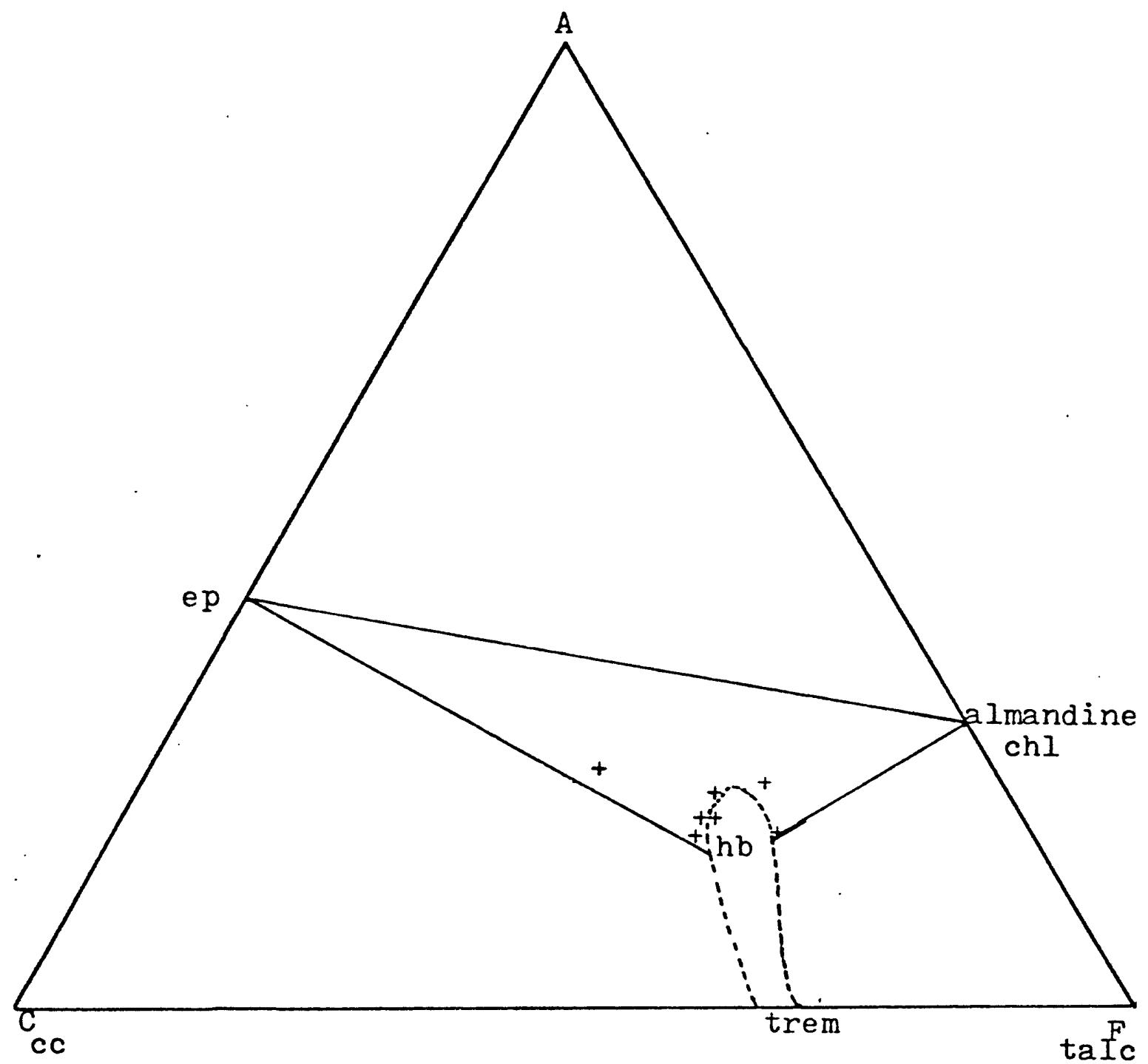

Figure 49. ACF diagram for the amphibolites (+). Epidote-amphibolite facies. $A=\mathrm{Al}_{2} \mathrm{O}_{3}+\mathrm{Fe}_{2} \mathrm{O}_{3}-\left(\mathrm{Na}_{2} \mathrm{O}+\mathrm{K}_{2} \mathrm{O}\right) ; \mathrm{C}=\mathrm{CaO}-3.3 \mathrm{P}_{2} \mathrm{O}_{5} ; \mathrm{F}=\mathrm{FeO}+\mathrm{MgO}+\mathrm{MnO}$. Values corrected for magnetite, ilmenite, and sphene, and expressed in molecular percents. 


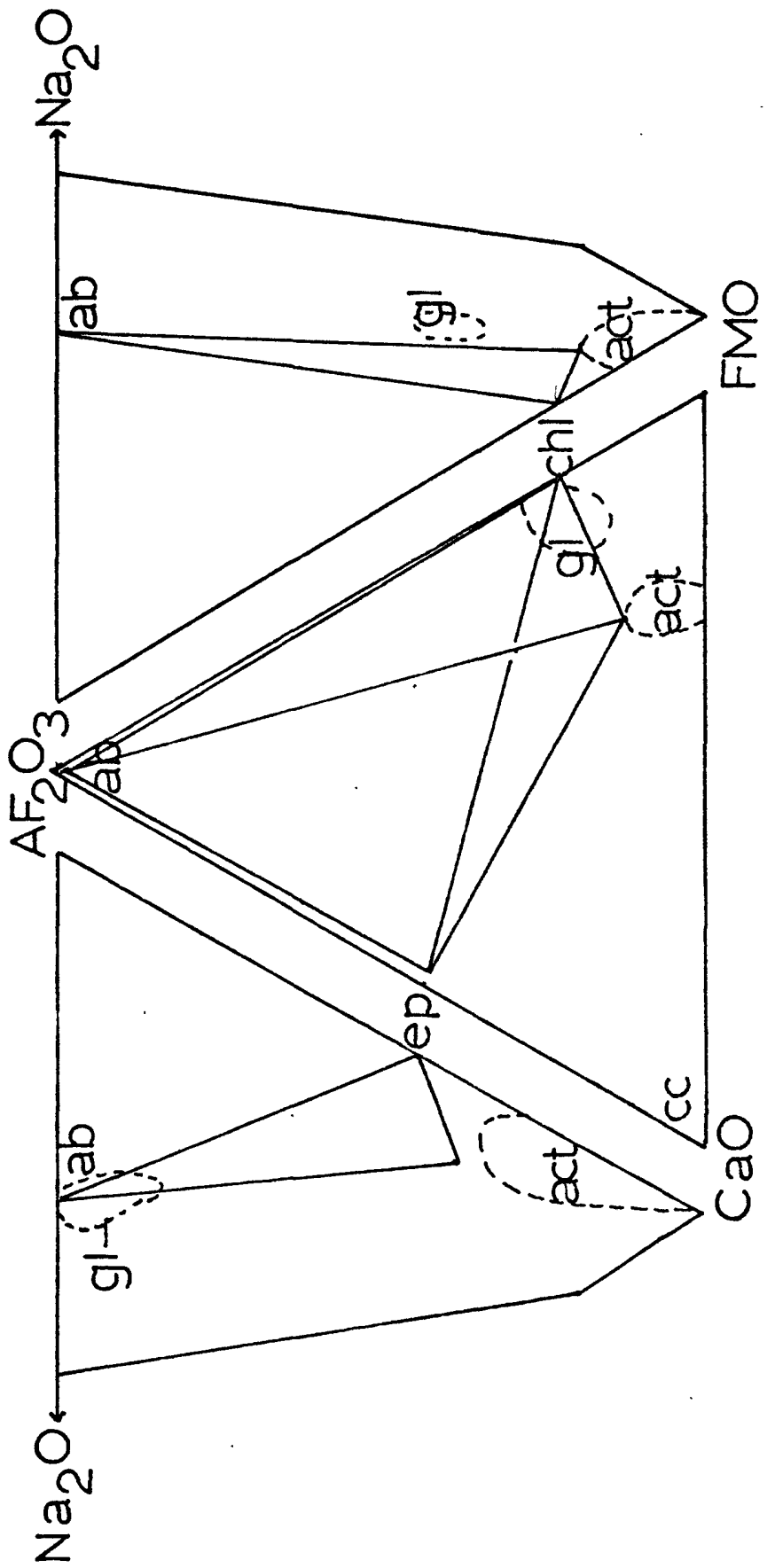

事

$0^{m}$ 葛

ए

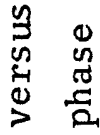

O $\frac{x}{0}$

之

芯

율

赵

?

苟

$>2$

유

(3)

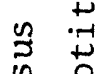

فำ

$O^{m} \stackrel{0}{\leftrightarrows}_{0}^{n}$

क i

ค ณ

苂 $\frac{1}{60}$

胥

की

m 5

语

崖昌

के क्ष

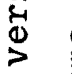

○

之

. चु

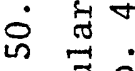

- ${ }_{0} 0$

苟 范

$\infty_{-1}^{\infty} \hat{\sigma}$

些孛 
The minera1 assemblage associated with the F1 deformation is: epidote-hornbiende-garnet \pm albite \pm quart $z \pm$ sphene. This assemblage is in the epidote-amphibolite facies as defined by Miyashiro (1973, p. 306) and in the quartz-albite-epidote-almandine subfacies of the greenschist facies as defined by Winkler (1967, p. 102).

\section{Coarse Grained Amphibolite, bac}

The amphibolite is a dark gray, medium to coarse grained rock composed of varying amounts of amphibole, albite, epidote, chlorite, garnet, quartz, biotite, sphene, sericite, and opaque minerals (Tab1e 4). The parallelism of hornblende laths defines the dominant S1 lineation. In some samples, fragmented amphiboles and epidote occur in a finer grained matrix of chlorite, biotite, epidote, and actinolite which are oriented parallel to $\mathrm{S} 2$.

\section{Amphibole. Amphibole comprises from $47.3 \%$ to $70 \%$ of the} coarse grained amphibolite. Anhedral to subhedral laths, pleochroic in light $\tan (x)$ to blue-green $(y)$ to olive green ( $z$ ) are here referred to as hornblende. Some hornblende grains are zoned, with the rims pleochroic in pale greens. Laird (1977) determined the amphibole composition in one sample from the summit of Belvidere Mountain using the microprobe. She concluded that the amphiboles have barroisitichornblende cores and barroisite rims. In addition to hornblende, distinctly smaller laths with higher birefringence and faint green pleochroism are present. This faint green amphibole is here referred to as actinolite.

Alignment of hornblende laths defines the dominant lineation associated with F1/D1. In some samples, hornblende is truncated and 
offset along minor shear surfaces. The laths are bent and exhibit a shredded appearance. Fine, fibrous actinolite needles are recrystallized along the shear surfaces. In sample 309, large fractured hornblende porphyroclasts occur in a fine grained matrix.

In some samples $(256,309,260)$, hornblende is partially altered to chlorite and biotite, thus resulting in a fibrous intergrowth of hornblende, biotite, and chlorite which is parallel to the S2 schistosity. This foliation is deformed by the F3 crenulate folds (Fig. 51)

Thus, the texture has developed in at least four stages: alignment of hornblende; shearing; alteration of hornblende and recrystallization of chlorite, epidote, and actinolite parallel to S2; crenulate folding.

Epidote. Epidote comprises from $15 \%$ to $30 \%$ of the coarse grained amphibolite. Epidote occurs as discrete, subhedral to euhedral grains. Many grains are randomly distributed throughout the sample. Epidote also occurs aligned parallel to the $\mathrm{S} 2$ schistosity. Several large grains are fractured nearly perpendicular (tension gashes) to S2, and the fractures are filled with chlorite. Most epidote grains are not zoned, although some optical zoning does occur. The cores may exhibit either stronger or weaker birefringence than the rims, and some grains are multiply zoned.

Epidote also is present as fracture fillings in garnet porphyroblasts.

Albite. Albite comprises from $1 \%$ to $7.3 \%$ of the coarse grained amphibolite. Albite occurs as discrete anhedral grains and 


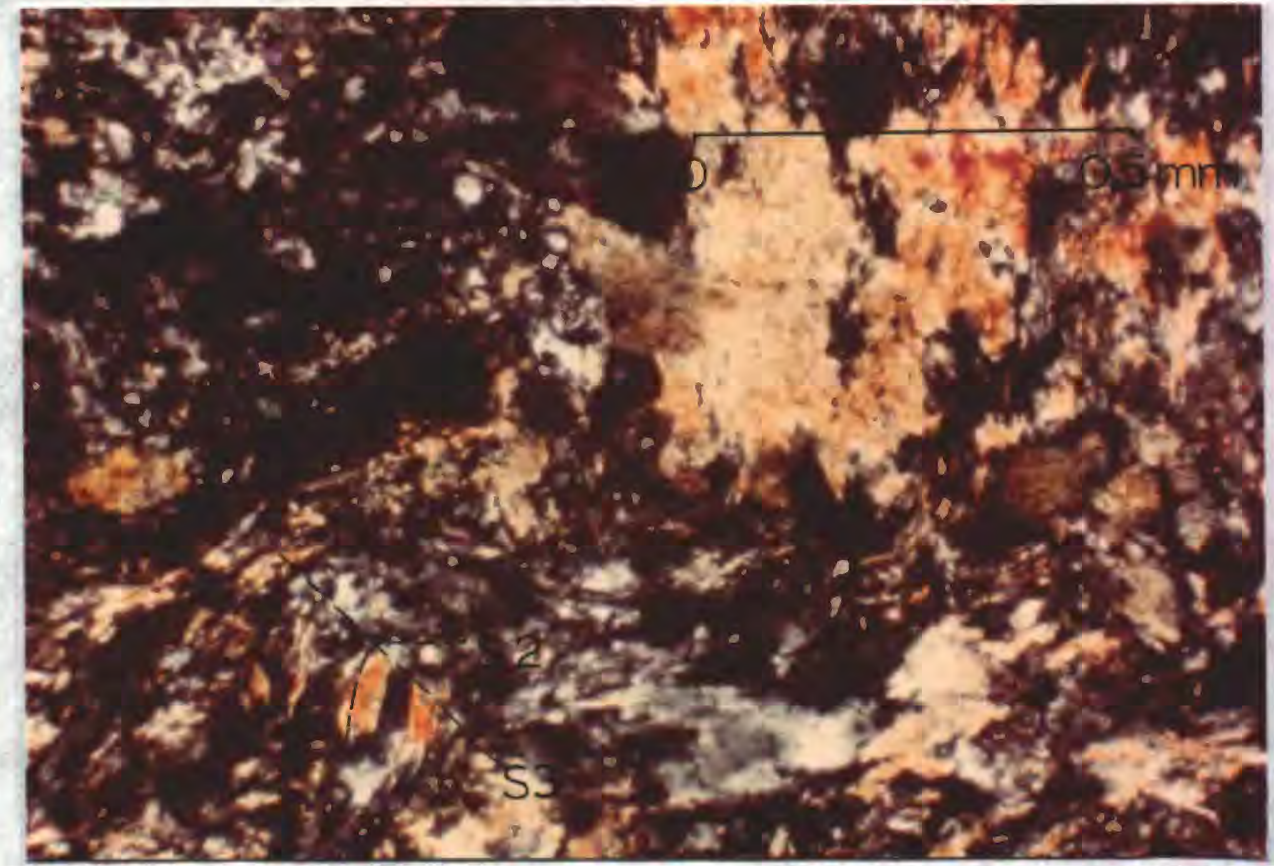

Figure 51. Large, SI/FI hornblende, sheared and altered to a fibrous aggregate of chlorite, biotite, and amphibole parallel to S2. S2 is folded by F3 crenulate folds. Bac-309. $\mathrm{X}$-nicols. 
as interlocking grain aggregates. Some grains exhibit multiple twins. Several of the larger grains are either bent, kinked, or fractured with offset twins (Fig. 52). Some of the grains have recrystallized as aggregates along the area of maximum flexure.

Albite is present as interlocking grains along fractures in garnet porphyroblasts, rimming the garnet porphyroblasts, and in pods with chlorite as an alteration of garnet. No albite occurs as porphyroblasts.

Chlorite. Chlorite comprises from $2 \%$ to $10.7 \%$ of the coarse grained amphibolite. Chlorite occurs in scaly aggregates and as an alteration of garnet and hornblende. Chlorite is present in shear zones, and occurs aligned with fibrous actinolite and epidote defining the s2 foliation.

Chlorite is pleochroic in green, and exhibits anomalous brown birefringence, although in sample 250 some chlorite exhibits anomalous blue birefringence.

Garnet. Garnet comprises from zero to 6 percent of the coarse grained amphibolite. Garnet occurs as porphyroblasts. Most of the porphyroblasts are fractured, with chlorite, biotite, albite, and epidote present along the fractures. Some of the porphyroblasts are completely altered to chlorite. A few of the porphyroblasts have amphibole inclusions. The garnet porphyroblasts are usually separated from the large hornblende laths by a thin rim of interlocking albite grains.

Quartz. Quartz comprises from zero to $6.6 \%$ of the coarse grained amphibolite. Quartz occurs as ribbon quartz, and as discrete 


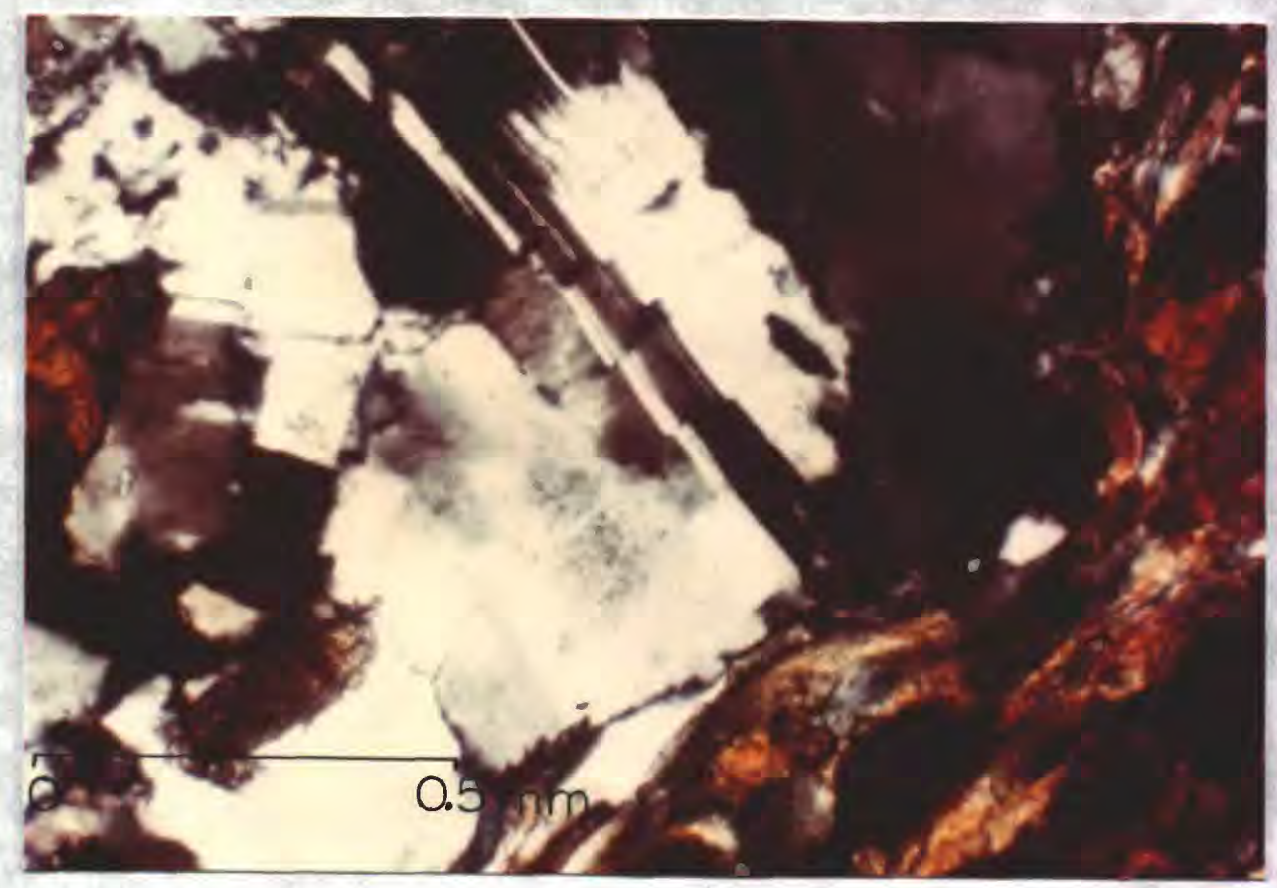

Figure 52. Kinked albite porphyroclast in bac-309. X-nicols. 
grains with undulatory extinction. The ribbon quartz is deformed by F3 crenulate folds.

Biotite. The amount of biotite in the coarse grained amphibolite varies from zero to $2.4 \%$. Biotite is present along cleavage planes in hornblende, and is intergrown with chlorite as an alteration of garnet.

Sphene. Anhedral to subhedral sphene comprises from $0.7 \%$ to $1.5 \%$ of the amphibolite. Some of the grains have ilmenite cores. The grains are randomly distributed in the rock. Most sphene grains have black, dusty rims.

Opaques. A black dust is present in trace amounts. Laird (1977) also reports pyrite in one sample of the amphibolite from the summit of Belvidere Mountain.

Coarse grained amphibolite--summary. The relationship of mineral growth and alteration to deformation is summarized in Figure 48. In the coarse grained amphibolite, the metamorphism associated with the $F 2$ deformation results in only partial retrogradation of the earlier mineralogy. Olive green hornblende is partially altered to chlorite and biotite, resulting in a sporadically developed fibrous texture which defines S2. Garnet exhibits partial to complete alteration to chlorite, albite and epidote. Large epidote grains (S1) are fractured, and some have recrystallized as finer grained aggregates and as discrete grains oriented paralle1 to S2. Quartz occurs as veins which cross-cut the lineation associated with F1. Quartz also is present as small aggregates with triple point junctions. 
The metamorphic assemblage associated with F1/D1 is comprised of zoned hornblende (barroisitic-hornblende cores with barroisite rims as described by Laird, 1977), twinned albite, zoned epidote, and garnet. The assemblage is: hornblende-albite-epidote-garnet \pm quartz \pm sphene \pm ilmenite. This assemblage is in the quartz-albite-epidotealmandine subfacies of the greenschist facies as defined by Winkler (1967) and in the epidote-amphibolite facies of the medium to high pressure facies series as defined by Miyashiro (1973). The expected mineral assemblages are shown on the ACF diagram in Figure 49.

The mineralogy associated with the F2 deformation is: ch1orite-epidote-albite \pm actinolite \pm biotite \pm quartz \pm sphene \pm opaque This assemblage is in the greenschist facies as defined by Winkler (1967) and Miyashiro (1973). The expected mineral assemblages are shown on the ACF diagram in Figure 44 .

Metasedimentary Rocks

The mineral assemblages in the metasedimentary rocks are not diagnostic of metamorphic grade. The metasedimentary rocks have textures relating to three deformational events and two metamorphic events.

In the rusty schist ( $r s$ ), chlorite and calcite occur in elongate lenses parallel to $\mathrm{S} 2$. Sericite, biotite, quartz veins, and interlocking aggregates of albite are also parallel to S2. Albite porphyroblasts contain inclusions of garnet, some of which are altered to chlorite. Thus, the mineral assemblage in the rusty schist is: quartz-albite-sericite-chlorite-biotite \pm calcite \pm opaque. This assemblage is consistent with metamorphism in the quartz-albite- 
epidote-biotite subfacies of the greenschist facies (Winkler, 1967) or the biotite zone.

There is sparse evidence for the metamorphism associated with F1 deformation in the rusty schist. Epidote, actinolite, sphene, and garnet partially altered to chlorite are present as inclusions in albite porphyroblasts. The presence of garnet may be indicative of early garnet grade metamorphism, although garnet is not necessarily indicative of metamorphic grade since spessartine may occur in the low temperature subfacies of the greenschist facies (Winkler, 1967).

In the albite gneiss (agn), the metamorphism associated with F1 produces compositional banding and a mineral assemblage of: muscovite-quartz-albite-chlorite. The bands and the muscovite grains are deformed by F2 and F3 folds. Some muscovite grains are aligned paralle1 to $\mathrm{S} 2$, although this may be due to either rotation or growth. Flattening and recrystallization of quartz and albite as interlocking grains may also be associated with F2.

In the sericite schist (ss), chlorite and sericite define an anastamozing network around elongate clusters of interlocking quartz and albite grains. The lenses are parallel to the $\mathrm{S} 2$ schistosity. The S2 schistosity is a slip cleavage which deforms the earlier S1 schistosity defined by alignment of chlorite and sericite.

Thus, the mineral assemblage in the sericite schist is not characteristic of a particular metamorphic facies or grade. However, the association of epidote and albite in the albite gneiss is characteristic of the Barrovian type greenschist facies metamorphism (Winkler, 1967), and garnet in the rusty schist may indicate an earlier higher grade metamorphism. Porphyroclasts and cataclastic textures are absent from any of the metasedimentary rocks. 
Summary and Discussion of Metamorphism

The hornblende isograd (Cady et al., 1963) and the garnet isograd (Doll et al., 1961) in the Belvidere Mountain area are not substantiated in the present work. A comparison of metasedimentary rocks above and below the isograd shows no change in mineral assemblages. The amphibole in the greenstone above and below the isograd is optically identical (actinolite). The mineral assemblage in the greenstone on both sides of the isograd is the same. All rocks exhibit a partial to complete greenschist facies metamorphic overprint. Any difference in metamorphic grade is due to survival of an earlier assemblage (epidote-amphibolite facies) in the coarse and fine grained amphibolites. Thus, the variation in the metamorphic mineral assemblages follows the fault contacts of the amphibolites. It is not appropriate to construct an isograd in the area.

The mineral assemblages in the rocks of the Belvidere Mountain area are the result of a complex metamorphic history. This history may be correlated with deformation. No change in the metamorphic mineralogy is associated with the F3 and F4 fold events. Metamorphism in the biotite zone of the greenschist facies is associated with the F2 deformation. The effects of this metamorphism vary from partial to complete overprinting of the earlier metamorphic mineral assemblages.

The metamorphism associated with the earliest deformation is more difficult to unravel since D1 includes both folding and faulting with variable age relationships. In a few thin sections of greenstone, chlorite pseudomorphs of garnet in albite porphyroblasts, chlorite pods, hornblende porphyroclasts, and lenses of amphibole aggregates imply an earlier (D1) higher grade (epidote-amphibolite facies) meta- 
morphism of the greenstone. However, the greenstone is present in the muscovite schist, suggesting that greenschist facies metamorphism also occurs prior to incorporation in the muscovite schist at the base of the thrust fault. Thus, greenschist facies metamorphism would also be pre- to syn-emplacement.

The coarse and fine grained amphibolites are incorporated in the muscovite schist and occur as fault slivers. Shearing and granulation of amphibole, epidote, and albite is visible in some thin sections of the amphibolites. Amphibole cores may indicate still an older metamorphic event. Thus, the amphibole lineation, metamorphism in the epidote-amphibolite facies, and subsequent retrogradation of the greenstone all pre-date the faulting of the muscovite schist.

Chemical data suggests that the amphibolites and greenstone are derived from the same protolith. Field and petrographic relationships establish a completely gradational sequence of coarse grained amphibolite, fine grained amphibolite, and greenstone, developed by shearing and recrystallization associated with D1. Thus, the early mineralogy and phases involved in the retrogradation of the greenstone may be inferred by considering the relict minerals in the greenstone, the mineralogy of the coarse and fine grained amphibolites, textural relationships, and the progressive change in modal mineralogy from coarse grained amphibolite to greenstone. From coarse grained amphibolite to fine grained amphibolite to greenstone there is an increase in actinolite, albite, chlorite, and calcite, a decrease in $\mathrm{Ca}-\mathrm{Na}$ amphibole (barroisite) and garnet, and epidote remains about the same with only a slight increase. Thus, the principal changes involved in the retrograde metamorphism of the greenstone from the earlier higher 
grade assemblage (Ca-Na amphibole, epidote, albite, garnet) are the breakdown of $\mathrm{Ca}-\mathrm{Na}$ amphibole and garnet to yield actinolite, albite, epidote and chlorite, and the recrystallization of epidote as finer grains and grain aggregates. Some grains are preserved as relict fragments. The appearance of calcite may reflect a variation in the partial pressure of $\mathrm{CO}_{2}$. The above reactions appear to be facilitated by a change in grain size due to shearing (i.e., confined to shear zones in some samples of the amphibolites).

It is suggested that the cores of the amphiboles reflect the oldest preserved metamorphism of the mafic rocks. This is followed by minor folding and development of epidote-amphibolite facies mineral assemblages. During transport to successively higher levels, shearing occurs in the amphibolites, truncating earlier folds. The greenstone, incorporated along the base of the thrust, experiences intense granulation and retrograde metamorphism prior to emplacement in the muscovite schist. Continued folding and metamorphism, within the same stress field orientation, is responsible for major F1 folds and continued greenschist facies metamorphism still associated with fault emplacement of the Belvidere Mountain Complex.

The principal textural differences between the metasedimentary rocks and the mafic rocks are the cataclastic textures and presence of mineral fragments (porphyroclasts) in the mafic rocks. The metamorphism of the metasedimentary rocks reflects two events, while the metamorphism of the mafic rocks reflects at least three events.

The variation in the effects of the greenschist facies metamorphism of the mafic rocks associated with F2 may reflect differences in grain size, the availability of fluids, the proximity to sediments, 
and/or differences in the pre-F2 mineralogy. Epidote-amphibolite facies metamorphism (bac, baf, bgs) and subsequent retrograde metamorphism of the greenstone to greenschist facies assemblages are a11 associated with D1 folds and faults. The variation in the effects of the metamorphism associated with $\mathrm{F} 2$ on the mafic rocks is thus most probably reflecting the differences in the pre-F2 mineralogy. 
Chapter 6

\section{SUMMARY}

The geology of the Belvidere Mountain area reflects a history of fault and fold deformation which produce a severely disrupted sequence of metasedimentary rocks, mafic metaigneous rocks with ocean floor affinitites, and serpentinized ultramafic rocks. Although some contacts are most probably by sedimentary interbedding, most contacts in the area are fault contacts recognized on the basis of truncation of lithologic units along a common surface, the presence of fault slivers, and truncations of minor structures. The stratigraphy is not a simple gradational sequence which youngs from west to east. In fact, the units in the area are best divided into four tectonostratigraphic packages, separated by faults, which do coincide with the previously mapped formations: schist and gneiss (wgn, rs, ss, agn) of the Hazens Notch Formation; ultramafic rocks (oud, outc), metaigneous rocks (bac, baf, bgs), and fault breccia (mus) of the Belvidere Mountain Complex; schist and phyllite (grp, bcp, gp, pgw, rbs) of the Ottauquechee Formation; green and tan schist and phyllite (ucs) of the Stowe Formation cut by metaigneous dikes. The contacts between these packages are fault contacts, and the stratigraphy within some of the packages is fault-constructed. The relative ages of the rocks in the area are not adequately documented, and it is not possible to accurately reconstruct the original stratigraphic relationships of these tectonic assemblages. 
Four fold events are recognized in the Belvidere Mountain area. Minor folds and foliations are associated with F1, F2 and F3, and no foliation is associated with F4. F1 folds are isoclinal to tight, with an axial surface foliation varying in strike from east-northeast to northwest. F2 folds are tight to isoclinal with a northeast striking axial plane. F3 folds are tight to open with an axial surface striking northeast, and F4 folds are northwest striking open folds. F1 folds were not recognized in the rocks on Hadley Mountain. The folds appear correlative with previously defined structures in Quebec (Osberg, 1965) and along the axis of the Green Mountain Anticlinorium (Eiben, 1976; Thompson, 1975).

Definition of the early F1 structures, on the basis of minor structures, is of questionable validity since faults both pre-date and post-date the minor structures. The faults are generally parallel to the S1 foliation. The SI foliation is considered to develop both prior to and during juxtaposition of the metaigneous rocks with the metasedimentary rocks. F2, F3, and F4 folds post-date the faults.

The coarse grained amphibolite, fine grained amphibolite, and greenstone are similar in both major and trace element chemistry. Trace element data supports an ocean tholeiite affinity for these rocks. These rocks, plus the underlying fault breccia (mus) are transported as thin fault slivers at the base of the serpentinite and, with the serpentinite comprise the Belvidere Mountain Complex. The estimated thickness of the amphibolites and greenstone is 175 meters (530 feet).

The rocks in the area exhibit a polymetamorphic history which is correlative with, and helps to define, the deformational history. 
The previously defined garnet and hornblende isograds (Doll et al., 1961; Cady et a1., 1963) at Belvidere Mountain are not substantiated. There is no change in metamorphic mineralogy of the metasedimentary rocks north and south of the isograd. The variation in metamorphic grade is confined to the rocks of the Belvidere Mountain Complex, and follows the faults contacts of the amphibolites and greenstone. Thus, this variation (epidote-amphibolite facies to greenschist facies) reflects cataclasis and retrograde metamorphism in the greenschist facies during shearing associated with transport and emplacement of the mafic metaigneous rocks at the base of the serpentinite. The textural and mineralogical gradational sequence of coarse grained amphibolite, fine grained amphibolite, and greenstone documents the early (D1) deformational and metamorphic history which may well have occurred during imbrication of ocean crust and westward transport of ophiolites onto the continental margin. Greenschist facies metamorphism is also associated with F2 folds. No changes in the metamorphic mineral assemblages are associated with F3 and F4 folds. 


\section{REFERENCES CITED}

Albee, A. L., 1957, Bedrock geology of the Hyde Park quadrangle, Vermont: U. S. Geol. Survey Quad. Map GQ-102.

, 1968, Metamorphic zones in northern Vermont, p. 329-341, in Zen, E-an, White, W. S., Hadley, J. B., and Thompson, J. B., Editors, Studies of Appalachian Geology: Northern and Maritime, New York, Interscience Publishers, $475 \mathrm{p}$.

Anderson, J. R., and A. L. Albee, 1975, Metamorphic veins as petrologic and structural markers of regional polymetamorphism in northern Vermont (Abs): Geol. Soc. America Abstracts Prog., p. 976 .

Brace, W. F., 1953, The geology of the Rutland area, Vermont: Vermont Geo1. Survey Bul1. 6, 120 p.

Brackett, R., 1979, Chemistry and structure of the metamorphic aureole of the Thetford Mines ophiolite suite, Quebec (Abs): The Green Mountain Geologist, v. 6, no. 1, p. 2.

Cady, W. M., 1956, Bedrock geology of the Montpelier quadrangle, Vermont: U. S. Geo1. Survey Quad. Map GQ-79.

, 1960, Stratigraphic and geotectonic relationships in northern Vermont and southern Quebec: Geo1. Soc. America Bul1., v. 71, p. 531-576.

, 1969, Regional tectonic synthesis of northwestern New England and adjacent Quebec: Geo1. Soc. America Mem. 120, 181 p.

, A. L. Albee, and A. H. Chidester, 1963, Bedrock geology and asbestos deposits of the upper Missisquoi Valley and vicinity: U. S. Geo1. Survey Bul1. 1122-B, 78 p.

Chidester, A. H., and W. M. Cady, 1972, Origin and emplacement of alpine-type ultramafic rocks: Nat. Phys. Sci., v. 240, p. 27-31.

Chidester, A. H., A. L. Albee, and W. M. Cady, 1978, Petrology, structure, and genesis of the asbestos-bearing ultramafic rocks of the Belvidere Mountain area in Vermont: U. S. Geol. Survey Prof. Paper 1016, $95 \mathrm{p}$.

Clark, T. H., 1934, Structure and stratigraphy of southern Quebec: Geo1. Soc. America Bul1., v. 45, no. 1, p. 1-20.

Coleman, R. G., 1977, Ophiolites: Ancient Oceanic Lithosphere?: New York, Springer-Verlag. 
Cooke, H. C., 1950, Geology of a southwestern part of the Eastern Townships of Quebec: Canada Geo1. Survey Mem. 257, 142 p.

Coombs, D. S., C. A. Landis, R. J. Norris, J. M. Sinton, D. J. Borns, and D. Crow, 1976, The Dun Mountain ophiolite belt, New Zealand, its tectonic setting, constitution, and origin, with special reference to the southern portion: American Jour. Sci., v. 276, p. 561-603.

Davies, H. L., 1971, Peridotite-gabbro-basalt complex in eastern Papua: an overthrust plate of oceanic mantle and crust: Australia Bur. Min. Res., Geol., and Geophys. Bull. 128, 48 p.

Do11, C. G., C. G. Cady, J. B. Thompson, Jr., and M. P. Billings, 1961, Centennial geologic map of Vermont: Montpelier, Vermont Geol. Survey.

Eiben, D. B., 1976, Stratigraphy and Structure of the Stimson Mountain area, Camels Hump quadrangle, north-central Vermont: Unpublished M. S. thesis, University of Vermont.

Graham, C. M., and P. C. England, 1976, Thermal regimes and regional metamorphism in the vicinity of overthrust faults: an example of shear heating and inverted metamorphic zonation from southern California: Earth Planet. Sci. Lett., v. 31, p. 142-152.

Johnson, M. R. W., 1961, Polymetamorphism in movement zones in the Caledonian thrust belt of northwest Scotland: Jour. Geol., v. 69, p. 4-17.

Keith, S. B., and G. W. Bain, 1932, Chrysotile asbestos: I, chrysotile veins: Econ. Geol., v. 27, p. 169-188.

Labotka, T. C., and A. L. Albee, 1978, Reaction at a serpentinization front, Belvidere Mountain ultramafic body, Vermont (Abs): Joint Ann. Meeting GAC, MAC, GSA, Abstr. Prog., v. 10, no. 7.

Laird, J., 1977, Phase Equilibria in Mafic Schist and the Polymetamorphic History of Vermont: Ph. D. thesis, California Inst. Tech., Pasedena, California.

, and A. L. Albee, 1975, Polymetamorphism and the first occurrence of glaucophane and omphacite in northern Vermont (Abs): Geol. Soc. America Abstr. Prog., v. 7, p. 1159.

Lanphere, M. A., and A. L. Albee, $1974,{ }^{40} \mathrm{Ar} /{ }^{39} \mathrm{Ar}$ age measurements in the Worcester Mountains: evidence of Ordovician and Devonian metamorphic events in northern Vermont: Am. Jour. Sci., v. 274, p. 545-555.

Laurent, R., 1975, Occurrence and origin of the ophiolites of southern Quebec, northern Appalachians: Can. Jour. Earth Sci., v. 12, p. 443-455. 
, 1977, Ophiolites from the northern Appalachians of Quebec, in Coleman, R. G., and Irwin, W. P., Editors, Ophiolites, State of Oregon, Dept. Geol. and Min. Indust. Bul1. 95.

Malpas, J. G., 1976, The Petrology and Petrogenesis of the Bay of Is lands Ophiolite Suite, Western Newfoundland: Ph. D. thesis, Memorial University, St. Johns, Newfoundland.

, R. K. Stevens, and D. F. Strong, 1973, Amphibolite associated with Newfoundland ophiolite: its classification and tectonic significance: Geology, Sept., p. 45-47.

Marsters, V. F., 1904, A preliminary report on a portion of the serpentine belt of Lamoille and Orleans counties, Vermont: Vermont State Geo1. 4th Bien. Rept., 1903-1904, p. 86-102.

, 1905, Petrography of the amphibolite, serpentine, and associated asbestos deposits of Belvidere Mountain, Vermont: Geol. Soc. America Bul1., v. 16, p. 419-446.

, 1906, A preliminary report on a portion of the serpentine belt of Lamoille and Orleans counties, Vermont: Vermont State Geo1. 5th Bien. Rept., 1905-1906, p. 35-61.

Miyashiro, A., 1970, Crystallization and differentiation in abyssal tholeiites and gabbros from mid-oceanic ridges: Earth Planet. Sci. Lett., v. 7, p. 361-365.

, 1973, Metamorphism and Metamorphic Be1ts: New York, John Wiley and Sons, $494 \mathrm{p}$.

, 1975, Classification, characteristics, and origin of ophiolites: Jour. Geol., v. 83, p. 249-281.

Murphy, V. J., and A. V. Lacroix, 1969, Magnetic survey of ultramafic bodies in the vicinity of Lowel1, Vermont: Econ. Geol., no. 6, $37 \mathrm{p}$.

Osberg, P. H., 1956, Stratigraphy of the Sutton Mountains, Quebec; key to the stratigraphic correlation in Vermont (Abs): Geol. Soc. America Bull., v. 67, p. 1820 .

, 1965, Structural geology of the Knowlton-Richmond area, Quebec: Geol. Soc. America Bul1., v. 76, no. 2, p. 223-250.

Pearce, J. A., 1975, Basalt geochemistry used to investigate past tectonic environments on Cyprus: Tectonophysics, v. 25, p. 41-67.

and J. R. Cann, 1973, Tectonic setting of basic volcanic rocks determined using trace element analyses: Earth Planet. Sci. Lett., v. 19, p. 290-300.

Perry, E. L., 1929, The geology of Bridgewater and Plymouth townships, Vermont: Vermont State Geol. 16th Bien. Rept. 1927-1928, p. 1-64. 
Shaw, A. B., 1958, Stratigraphy and structure of the St. Albans area, northwestern Vermont: Geol. Soc. America Bul1., v. 46, 97 p.

Spry, A., 1969, Metamorphic Textures: Oxford, Pergamon Press Ltd., $350 \mathrm{p}$.

St. Julien, P., and C. Hubert, 1975, Evolution of the Taconian orogen in the Quebec Appalachians: Amer. Jour. Sci., v. 275-A, p. 337362 .

Thompson, G., and W. G. Me1son, 1972, The petrology of oceanic crust across fracture zones in the Atlantic Ocean: evidence of a new kind of sea-floor spreading: Jour. Geol., v. 80, p. 526-538.

Thompson, P., 1975, Stratigraphy and Structure of Shattuck Ridge, Bakersfield and Waterville, Vermont: Unpublished M. S. thesis, University of Vermont.

Winkler, H. G. F., 1967, Petrogenesis of Metamorphic Rocks: New York, Springer-Verlag, 237 .

Woodcock, N. H., and A. H. F. Robertson, 1977, Origins of some ophiolite-related metamorphic rocks of the "Tethyan" belt:

Geology, v. 5, p. 373-376.

Williams, H., and W. R. Smith, 1973, Metamorphic aureoles beneath ophiolite suites and alpine peridotites: tectonic implications with west Newfoundland examples: Amer. Jour. Sci., v. 273, p. 594-621. 


\section{LOCATION AND DESCRIPTION OF ANALYZED SAMPLES}

Bgs-91: This rock is a light-green, buff-weathering, fine grained greenstone with albite in relief on the weathered surface. Thin $(<5 \mathrm{~mm})$ lenses of coarser-grained amphibole aggregates are visible in the outcrop. The sample is comprised of chlorite, actinolite, epidote, albite, sphene, quartz, and opaques. The outcrop is located $8500 \mathrm{NI2E}$ of Eden.

Bgs-99: This rock is a fine grained, buff-weathering, graygreen schistose greenstone composed of chlorite, albite, calcite, quartz, sphene, pyrite, and magnetite. The outcrop is located 6000 feet NIOE of Eden.

Bgs-105: This rock is a green to buff weathering, gray-green fine grained, banded greenstone. The greenstone is composed of albite, chlorite, actinolite, epidote, biotite, and opaques. Sample 105 is from an outcrop located 5300 feet N05W of Eden.

Bgs-106: This rock is a fine grained, tan-weathering, graygreen, schistose greenstone with albites in relief on the weathered surface. The greenstone is comprised of actinolite, albite, chlorite, epidote, calcite, biotite, and pyrite. The outcrop is located 6400 feet N03E of Eden.

Bgs-125: This rock is a dark gray to green weathering, fine grained, banded greenstone. The bands are defined by concentrations of albite and of epidote and chlorite in layers. The greenstone is composed of albite, chlorite, epidote, sphene, biotite, and opaques. The outcrop is located 1.4 miles N02W of Eden at the contact with the sericite schist (ss). 
Bgs-142: This rock is a tan weathering, fine grained, schistose greenstone with quartz veins. The greenstone is composed of actinolite, epidote, chlorite, albite, calcite, quartz, sphene, and pyrite. The outcrop is located 1.7 miles N05E of Eden.

Bgs-149: This rock is a gray-green weathering, fine grained, schistose, banded greenstone. The greenstone is composed of actinolite, epidote, chlorite, albite, calcite, quartz, sphene, biotite, and pyrite in decreasing order of abundance. The outcrop is located 1.73 miles N02W of Eden.

Bgs-173: This rock is a fine grained, buff-weathering, schistose greenstone composed of albite, actinolite, chlorite, epidote, calcite, quartz, sphene, and pyrite in decreasing order of abundance. The outcrop is located 2.23 miles north of Eden.

Bgs-176: This rock is a fine grained, schistose, dark and light green banded greenstone with quartz veins. The greenstone is composed of albite, chlorite, actinolite, epidote, sphene, quartz, biotite, and pyrite in decreasing order of abundance. The outcrop is located 2.23 miles N05W of Eden.

Bgs-184: This rock is a dark gray-green weathering, fine grained, schistose, banded greenstone with albite porphyroblasts and white blotches of calcite. The rock is composed of chlorite, albite, epidote, calcite, biotite, actinolite, sphene, and pyrite in decreasing order of abundance. This outcrop is located $2.25 \mathrm{miles}$ N02W of Eden.

Bgs-189: This rock is a fine grained, buff-green weathering, schistose, banded greenstone with albites in relief on the weathered surface in some of the compositional bands. The rock is composed of 
actinolite, albite, epidote, chlorite, quartz, sphene, and opaques in decreasing order of abundance. The outcrop is located 1.34 miles $N 27 \mathrm{~W}$ of Eden near the contact with the rusty schist (rs).

Bgs-190: This rock is a fine grained, gray-green, schistose, faintly banded greenstone composed of actinolite, albite, calcite, epidote, chlorite, and sericite in decreasing order of abundance. The outcrop is located 1.33 miles N33W of Eden at the contact with the rusty schist.

Bgs-192: This rock is a buff-weathering, fine grained, schistose greenstone with a pitted surface. Albite is in relief on the weathered surface. White blotches of calcite are visible on the fresh surface. The greenstone is composed of albite porphyroblasts and calcite-albite aggregates in a fine grained matrix of actinolite, epidote, and sphene. The S2 schistosity is defined by alignment of actinolite, chlorite, and albite porphyroblasts with helicitic textures. This schistosity is overprinted by the S3 crenulate foliation. The outcrop is located 1.23 miles $\mathrm{N} 29 \mathrm{~W}$ of Eden at the contact with the sericite schist.

Bgs-195: This rock is a fine grained, schistose, dark and light green banded greenstone with quartz veins. The rock is composed of chlorite, actinolite, albite, epidote, calcite, sphene, magnetite, and biotite. F2 isoclinal folds deform the compositional bands. The outcrop is an easily accessible exposure located along the roadside 1.6 miles $\mathrm{N} 2 \mathrm{TW}$ of Eden at the contact with the rusty schist.

Bgs-200: This rock is a buff-green weathering, fine grained, schistose, banded greenstone with albite porphyroblasts in relief on the weathered surface. The rock is composed of chlorite, actinolite, 
albite, epidote, sphene, biotite, and opaques in decreasing order of abundance. The sample was taken from an outcrop located 1.42 miles N05W of Eden.

Bgs-205: Sample 205 is from a fine grained, light and dark green banded, schistose greenstone. F2 isoclinal folds are visible in the outcrop. The outcrop is located 1.64 miles $\mathrm{N} 21 \mathrm{~W}$ of Eden on a sma11 knoll in the swamp.

Bgs-208: This rock is a fine grained, homogeneous, graygreen, schistose greenstone composed of actinolite, chlorite, albite, epidote, sphene, and an opaque dust in decreasing order of abundance. The outcrop is located 1.67 miles NO5W of Eden.

Bgs-210: This rock is a fine grained, brown-green weathering faintly banded, schistose greenstone composed of albite, chlorite, actinolite, epidote, calcite, sphene, and magnetite. Three foliations are visible in this sample. The oldest foliation is the compositional bands. The compositional bands are isoclinally folded, and parallelism of amphiboles defines the associated schistosity. The two earlier foliations are overprinted by a crenulate foliation. The outcrop is located $1.8 \mathrm{miles}$ N05W of Eden.

Bgs-219a: This rock is a fine grained, brown-green weathering, dark and light green banded, schistose greenstone. The rock is cut by discontinuous calcite veins. The compositional layers are isoclinally folded (F2), and a faint schistosity associated with the folds is defined by chlorite. The rock is composed of albite, chlorite, epidote, quartz, calcite, sphene, and pyrite. The outcrop is located 1.7 miles $\mathrm{N} 23 \mathrm{~W}$ of Eden. 
Bgs-221: This rock is a buff weathering, fine grained, dark gray-green, schistose greenstone composed of albite, actinolite, chlorite, epidote, biotite, sphene, and opaque material as a red stain. The outcrop is located behind the barn 2.17 miles $N 20 \mathrm{~W}$ of Eden at the contact with the rusty schist.

Bac-250: This rock is a massive, dark gray, medium to coarse grained amphibolite with garnet porphyroblasts. The garnets are partially altered to chlorite, thus some porphyroblasts are green. The amphibolite is composed of hornblende, epidote, chlorite, albite, quartz, garnet, biotite, sphene, and an opaque dust. The outcrop is located at the summit of Belvidere Mountain.

Bac-256: This rock is a gray-brown weathering, medium grained amphibolite with garnet porphyroblasts. The amphibolite is banded, with the bands defined by a variation in grain size, and by the presence and absence of garnet. The amphibolite is composed of amphibole, epidote, chlorite, albite, quartz, biotite, sphene, garnet, sericite, and opaques. The outcrop is located 3.59 miles N12E of Eden on the VAG property.

Baf-257: This rock is a fine grained, dark green-gray amphibolite with a dominant foliation defined by amphibole and epidote. Tiny amphibole laths are visible in the massive, faintly foliated rock. The amphibolite is composed almost entirely of epidote and amphibole, although minor amounts of albite, biotite, chlorite, sphene, and $a$ black dust are present in thin section. Thin shear surfaces are visible in thin section. The amphibole laths (hornblende) are broken and ragged, with fibrous amphibole (actinolite), albite, and biotite 
comprising the shear zones. The outcrop is located 3.59 miles N13E of Eden on the VAG property.

Bac-260: This rock is a dark gray, medium grained amphibolite with a dominant foliation defined by the parallelism of hornblende 1aths. In thin section, many of the amphibole and epidote grains are bent and fractured, with chlorite present along the fractures. The amphibolite is composed of amphibole, epidote, and lesser amounts of albite, quartz, chlorite, and sphene with ilmenite cores. The outcrop is located 3.5 miles N1OE of Eden at the contact with the fine grained amphibolite.

Bgs-268: This rock is a 1ight green, schistose, banded greenstone composed of epidote, chlorite, actinolite, albite, quartz, biotite, and sphene. The compositional bands are isoclinally folded (F2), and three foliations are visible (S1, S2, S3). The outcrop is located 2.26 miles $\mathrm{N} 18 \mathrm{~W}$ of Eden at the contact with the rusty schist. Bgs-279: This rock is a light and dark green banded, fine grained, schistose greenstone composed of epidote, albite, chlorite, actinolite, quartz, magnetite, and biotite. Three foliations are visible, although faint. The outcrop is located 2.14 miles N05W of Eden.

Bgs-280: This rock is a buff-green weathering, fine grained, gray-green, schistose greenstone composed of chlorite, actinolite, epidote, albite, sphene, pyrite, and a dusty red opaque. The outcrop displays abundant minor folds (F2). The outcrop is located 2.25 miles N06W of Eden.

Bgs-297: This sample is a fine grained, green-gray, 1ight gray weathering greenstone composed of chlorite, epidote, calcite, 
albite, sphene, quartz, and opaques in decreasing order of abundance. The outcrop is located approximately 4 miles N05W of Eden.

Bgs-297a: This sample is a fine grained, gray-green greenstone composed of chlorite, epidote, calcite, albite, quartz, sphene, and opaques in decreasing order of abundance. The outcrop is located approximately 3.8 miles N06W of Eden at the contact with the muscovite schist.

Bgs-298: This rock is a fine grained, gray-green, schistose greenstone with albite porphyroblasts in relief on the weathered surface. The greenstone is composed of actinolite and epidote, with lesser amounts of albite, chlorite, sphene, quartz, calcite, biotite, and opaques. Quartz is present as veins. The outcrop is located 0.74 mile S20W of the summit of Belvidere Mountain.

Bgs-300: This rock is a fine grained, blue-green greenstone with albites in relief on the weathered surface. The greenstone contains quartz veins. Three foliations (S1, S2, S3) are visible in the rock. The greenstone is composed of actinolite, epidote, quartz, chlorite, albite, biotite, and sphene in decreasing order of abundance. Some chlorite occurs as pseudomorphs of garnet. Quartz occurs as ribbon quartz. The outcrop is located $0.8 \mathrm{mile} 520 \mathrm{~W}$ of the summit of Belvidere Mountain, near the contact with the muscovite schist.

Baf-305: This rock is a dark gray, massive, fine to medium grained amphibolite with garnet porphyroblasts. No foliation is visible in outcrop, although in thin section a faint foliation is defined by parallelism of amphibole laths. The amphibolite is composed of amphibole, epidote, chlorite, albite, garnet, and sphene. Chlorite and albite occur mainly as an alteration of garnet. The outcrop is located 400 feet S18E of the summit of Belvidere Mountain. 
Baf-307: This rock is a massive, dark gray, gray weathering fine to medium grained amphibolite composed of amphibole, epidote, garnet porphyroblasts, albite, chlorite, sphene, biotite, quartz, and a black, opaque dust. The outcrop is located 700 feet S18E of the tower at the summit of Belvidere Mountain.

Baf-308: This rock is a dark gray, fine grained amphibolite with garnet porphyroblasts. A single faint foliation, defined by parallellism of amphiboles, is visible in the massive rock. The rock is composed of amphibole, epidote, garnet, chlorite, quartz, sphene, and a black opaque dust. The outcrop is located 900 feet S18E of the summit of Belvidere Mountain.

Bac-309: This rock is a dark gray, medium to coarse grained amphibolite with a single foliation, visible in outcrop, defined by parallelism of hornblende laths. The rock is cut by thin (less than $1 \mathrm{~mm}$ ) shear surfaces which are composed of a very fine grained mass of actinolite and chlorite. The amphibolite is composed of hornblende, actinolite, epidote, albite, chlorite, sphene with ilmenite cores, pyrite, and a black opaque dust. The outcrop is located 300 feet S60w of the summit of Belvidere Mountain.

Bac-310: This rock is a dark gray, medium grained amphibolite with garnet porphyroblasts. 310 is slightly finer grained than most of the coarse grained amphibolite. The rock is composed of amphibole', epidote, garnet, albite, chlorite, sphene, and a black opaque dust in decreasing order of abundance. Albite and chlorite are present along fractures in garnet porphyroblasts, and chlorite also occurs along cleavage planes in hornblende. The outcrop is located 850 feet $\mathrm{N} 18 \mathrm{~W}$ of the summit of Belvidere Mountain. 
Bgs-314: This rock is a buff-green weathering, fine grained, schistose, light green greenstone with albites in relief on the weathered surface. The rock is composed of actinolite, albite, chlorite, epidote, sericite, sphene, and quartz. The outcrop is located 2.56 miles $\mathrm{N} 13 \mathrm{~W}$ of Eden.

Bgs-315: This rock is a fine grained, gray-green, schistose greenstone with albite porphyroblasts. The outcrop is located 2.54 miles $\mathrm{N} 12 \mathrm{~W}$ of Eden at the contact with the rusty schist.

Bgs-319: This rock is a buff-green weathering, fine grained, homogeneous, schistose greenstone with albite porphyroblasts. The rock is composed of chlorite, albite, calcite, quartz, sphene, and pyrite. The outcrop is located 2.62 miles N05W of Eden.

Bgs-321: This rock is a light green weathering, fine grained, dark gray-green, schistose greenstone with albite porphyroblasts in relief on the weathered surface. The greenstone is composed of chlorite, albite, epidote, calcite, sphene, and pyrite in decreasing order of abundance. Several large, faint amphiboles (hornblende) are present at a high angle to the dominant schistosity, and are partially recrystallized to actinolite needles. The outcrop is located 2.75 miles N07W of Eden.

Bgs-325: This rock is a fine grained, gray-green, schistose banded greenstone. The light bands are defined by concentrations of epidote. The outcrop displays abundant minor folds (F2). The outcrop is located 3.03 miles N16W of Eden.

Bgs-329: This rock is a fine grained, rusty and green weathering, schistose, gray-green greenstone with albite porphyroblasts. The rock is mainly composed of albite porphyroblasts in a 
very fine grained matrix of chlorite and epidote. The outcrop is located 3.09 miles N10W of Eden. 
APPENDIX 2

CHEMICAL DATA AND HISTOGRAMS

Chemical Analyses of the Greenstone and Amphibolites

\begin{tabular}{|c|c|c|c|c|c|c|}
\hline Sample & $\begin{array}{l}\text { bgs } \\
91 \\
\end{array}$ & $\begin{array}{l}\mathrm{bgs} \\
99 \\
\end{array}$ & $\begin{array}{l}\mathrm{bgs} \\
105 \\
\end{array}$ & $\begin{array}{l}\text { bgs } \\
106 \\
\end{array}$ & $\begin{array}{l}\text { bgs } \\
125 \\
\end{array}$ & $\begin{array}{l}\text { bgs } \\
142 \\
\end{array}$ \\
\hline $\mathrm{SiO}_{2}$ & 47.80 & 43.10 & 47.60 & 47.80 & 46.00 & 47.10 \\
\hline $\mathrm{TiO}_{2}$ & 1.18 & 0.99 & 1.08 & 1.14 & 1.80 & 1.33 \\
\hline $\mathrm{Al}_{2} \mathrm{O}_{3}$ & 14.30 & 12.90 & 15.38 & 14.10 & 16.80 & 14.50 \\
\hline $\mathrm{Fe}_{2} \mathrm{O}_{3}$ & 5.95 & 1.64 & 4.61 & 8.44 & 12.69 & 7.14 \\
\hline $\mathrm{FeO}$ & 5.01 & 7.89 & 6.02 & 2.16 & 2.04 & 4.61 \\
\hline $\mathrm{MnO}$ & 0.18 & 0.23 & 0.16 & 0.19 & 0.15 & 0.21 \\
\hline MgO & 7.51 & 7.84 & 9.44 & 7.44 & 3.63 & 7.44 \\
\hline $\mathrm{CaO}$ & 8.74 & 9.16 & 6.37 & 9.30 & 7.38 & 9.26 \\
\hline $\mathrm{Na}_{2} \mathrm{O}$ & 2.51 & 2.69 & 3.22 & 2.97 & 4.85 & 2.53 \\
\hline $\mathrm{K}_{2} \mathrm{O}$ & 0.09 & 0.02 & 0.13 & 0.26 & 0.09 & 0.19 \\
\hline $\mathrm{P}_{2} \mathrm{O}_{5}$ & 0.10 & 0.12 & 0.12 & 0.13 & 0.23 & 0.20 \\
\hline LOI & 6.24 & 12.11 & 5.29 & 4.92 & 3.19 & 5.24 \\
\hline Total & 99.61 & 98.69 & 99.42 & 98.85 & 98.85 & 99.75 \\
\hline $\mathrm{FeO}^{*}$ & 10.35 & 9.36 & 10.16 & 9.75 & 13.45 & 11.03 \\
\hline $\mathrm{FeO} * / \mathrm{MgO}$ & 1.38 & 1.19 & 1.08 & 1.31 & 3.71 & 1.48 \\
\hline $\mathrm{Nb}$ & -- & 10 & 10 & 8 & -- & 5 \\
\hline $\mathrm{Zr}$ & --- & 68 & 68 & 79 & --- & 86 \\
\hline$Y$ & --- & 25 & 25 & 30 & --- & 36 \\
\hline $\mathrm{Sr}$ & -- & 150 & 124 & 130 & --- & 119 \\
\hline $\mathrm{Rb}$ & --- & 1 & 4 & 9 & --- & 5 \\
\hline $\mathrm{Pb}$ & --- & --- & --- & --- & --- & 4 \\
\hline $\mathrm{Ga}$ & --- & 17 & 17 & 20 & --- & 19 \\
\hline $\mathrm{Zn}$ & --- & 129 & 104 & 98 & --- & 112 \\
\hline $\mathrm{Ni}$ & --- & 85 & 104 & 87 & --- & 110 \\
\hline $\mathrm{Cu}$ & --- & 156 & 59 & 77 & --- & 67 \\
\hline $\mathrm{Ba}$ & --- & 16 & 24 & 88 & -- & 45 \\
\hline V & --- & 300 & 285 & 313 & --- & 348 \\
\hline $\mathrm{Cr}$ & --- & 200 & 198 & 188 & --- & 222 \\
\hline $\mathrm{Ti}$ & --- & 5,935 & 6,474 & 6,834 & --- & 7,913 \\
\hline
\end{tabular}

Major element oxides in weight percent

Trace element analyses in ppm

LOI : loss on ignition

$\mathrm{FeO}^{*}$ : total iron as $\mathrm{FeO}$ 
APPENDIX 2 (cont.)

Chemical Analyses of the Greenstone and Amphibolites

\begin{tabular}{|c|c|c|c|c|c|c|}
\hline Sample & $\begin{array}{l}\text { bs } \\
149 \\
\end{array}$ & $\begin{array}{l}\text { bgs } \\
173 \\
\end{array}$ & $\begin{array}{l}\mathrm{bgs} \\
176 \\
\end{array}$ & $\begin{array}{l}\mathrm{bgs} \\
184 \\
\end{array}$ & $\begin{array}{l}\text { bgs } \\
189 \\
\end{array}$ & $\begin{array}{l}\mathrm{bgs} \\
190 \\
\end{array}$ \\
\hline $\mathrm{SiO}_{2}$ & 44.00 & 49.10 & 47.00 & 46.12 & 46.70 & 41.60 \\
\hline $\mathrm{TiO}_{2}$ & 1.80 & 1.02 & 2.43 & 1.27 & 1.01 & 0.86 \\
\hline $\mathrm{Al}_{2} \mathrm{O}_{3}$ & 15.30 & 14.16 & 11.50 & 13.36 & 14.40 & 13.30 \\
\hline $\mathrm{Fe}_{2} \mathrm{O}_{3}$ & 7.80 & 3.75 & 11.48 & 6.40 & 4.68 & 6.19 \\
\hline $\mathrm{FeO}$ & 5.53 & 6.92 & 7.91 & 6.31 & 6.90 & 2.49 \\
\hline MnO & 0.20 & 0.20 & 0.22 & 0.20 & 0.21 & 0.17 \\
\hline MgO & 7.05 & 7.93 & 6.00 & 6.00 & 8.30 & 5.61 \\
\hline $\mathrm{CaO}$ & 10.37 & 9.40 & 8.27 & 7.64 & 10.23 & 15.02 \\
\hline $\mathrm{Na}_{2} \mathrm{O}$ & 1.32 & 2.90 & 1.63 & 3.14 & 2.30 & 2.53 \\
\hline $\mathrm{K}_{2} \mathrm{O}$ & 0.35 & 0.05 & 0.11 & 0.58 & 0.05 & 0.94 \\
\hline $\mathrm{P}_{2} \mathrm{O}_{5}$ & 0.18 & 0.11 & 0.23 & 0.09 & 0.11 & 0.11 \\
\hline LOI & 4.86 & 4.41 & 3.66 & 8.52 & 4.03 & 9.36 \\
\hline Tota 1 & 98.76 & 99.95 & 100.44 & 99.63 & 98.92 & 98.18 \\
\hline $\mathrm{FeO} *$ & 12.54 & 9.60 & 18.23 & 12.07 & 11.11 & 8.06 \\
\hline $\mathrm{FeO} * / \mathrm{MgO}$ & 1.78 & 1.21 & 3.04 & 2.01 & 1.34 & 1.44 \\
\hline $\mathrm{Nb}$ & 8 & 10 & 14 & 10 & 6 & 6 \\
\hline $\mathrm{Zr}$ & 110 & 78 & 144 & 71 & 60 & 65 \\
\hline$Y$ & 40 & 31 & 58 & 31 & 29 & 22 \\
\hline $\mathrm{Sr}$ & 104 & 124 & 86 & 60 & 113 & 189 \\
\hline $\mathrm{Rb}$ & 13 & 4 & 4 & 38 & 2 & 25 \\
\hline $\mathrm{Pb}$ & 5 & --- & 7 & 4 & --- & -- \\
\hline $\mathrm{Ga}$ & 20 & 18 & 23 & 16 & 20 & 17 \\
\hline $\mathrm{Zn}$ & 122 & 131 & 158 & 106 & 114 & 74 \\
\hline $\mathrm{Ni}$ & 132 & 95 & 35 & 60 & 89 & 179 \\
\hline $\mathrm{Cu}$ & 113 & 100 & 68 & 82 & 40 & 86 \\
\hline $\mathrm{Ba}$ & 54 & 10 & 53 & 45 & 26 & 122 \\
\hline V & 344 & 290 & 668 & 370 & 293 & 202 \\
\hline $\mathrm{Cr}$ & 248 & 180 & 24 & 114 & 152 & 433 \\
\hline $\mathrm{Ti}$ & 10,791 & 6,115 & 14,568 & 7,614 & 6,055 & 5,150 \\
\hline
\end{tabular}

Major element oxides expressed in weight percent Trace elements expressed in parts per million LOI: loss on ignition

Fe0*: total iron as $\mathrm{FeO}$ 
APPENDIX 2 (cont.)

Chemical Analyses of the Greenstone and Amphibolites

\begin{tabular}{|c|c|c|c|c|c|c|}
\hline Sample & $\begin{array}{l}\text { bgs } \\
192 \\
\end{array}$ & $\begin{array}{l}\text { bgs } \\
195 \\
\end{array}$ & $\begin{array}{l}\text { bgs } \\
200 \\
\end{array}$ & $\begin{array}{l}\text { bgs } \\
205 \\
\end{array}$ & $\begin{array}{l}\text { bgs } \\
208 \\
\end{array}$ & $\begin{array}{l}\text { bgs } \\
210\end{array}$ \\
\hline $\mathrm{SiO}_{2}$ & 48.06 & 46.60 & 45.90 & 46.70 & 47.01 & 49.70 \\
\hline $\mathrm{TiO}_{2}$ & 1.13 & 1.60 & 1.69 & 1.73 & 1.55 & 1.46 \\
\hline $\mathrm{Al}_{2} \mathrm{O}_{3}$ & 13.60 & 12.90 & 13.90 & 13.40 & 13.88 & 13.41 \\
\hline $\mathrm{Fe}_{2} \mathrm{O}_{3}$ & 3.32 & 7.94 & 6.71 & 7.86 & 5.04 & 7.55 \\
\hline $\mathrm{FeO}$ & 6.98 & 6.50 & 6.12 & 7.25 & 6.14 & 6.81 \\
\hline $\mathrm{MnO}$ & 0.21 & 0.21 & 0.20 & 0.27 & 0.20 & 0.19 \\
\hline Mg0 & 9.42 & 6.06 & 7.33 & 6.53 & 8.04 & 6.14 \\
\hline $\mathrm{CaO}$ & 7.70 & 10.42 & 10.14 & 9.20 & 10.59 & 5.65 \\
\hline $\mathrm{Na}_{2} \mathrm{O}$ & 2.29 & 2.51 & 2.19 & 2.38 & 2.37 & 5.09 \\
\hline $\mathrm{K}_{2} \mathrm{O}$ & 0.01 & 0.17 & 0.06 & 0.19 & 0.06 & 0.08 \\
\hline $\mathrm{P}_{2} \mathrm{O}_{5}$ & 0.05 & 0.19 & 0.17 & 0.16 & 0.21 & 0.14 \\
\hline LOI & 8.21 & 3.78 & 4.11 & 3.62 & 4.01 & 2.99 \\
\hline Tota1 & 100.98 & 98.88 & 98.52 & 99.29 & 99.10 & 99.21 \\
\hline $\mathrm{FeO}$ * & 9.96 & 13.28 & 12.14 & 14.31 & 10.67 & 13.56 \\
\hline $\mathrm{FeO} * / \mathrm{MgO}$ & 1.06 & 2.19 & 1.66 & 2.19 & 1.33 & 2.21 \\
\hline $\mathrm{Nb}$ & 6 & 8 & 10 & 8 & 13 & 10 \\
\hline $\mathrm{Zr}$ & 68 & 94 & 112 & 101 & 100 & 89 \\
\hline $\mathrm{Y}$ & 29 & 42 & 45 & 45 & 34 & 40 \\
\hline $\mathrm{Sr}$ & 101 & 176 & 145 & 178 & 196 & 141 \\
\hline $\mathrm{Rb}$ & 5 & 13 & 5 & 9 & 4 & 5 \\
\hline $\mathrm{Pb}$ & 3 & 10 & 1 & 3 & 9 & --- \\
\hline $\mathrm{Ga}$ & 17 & 23 & 22 & 23 & 18 & 20 \\
\hline $\mathrm{Zn}$ & 189 & 121 & 106 & 126 & 112 & 123 \\
\hline $\mathrm{Ni}$ & 77 & 61 & 101 & 62 & 125 & 64 \\
\hline $\mathrm{Cu}$ & 146 & 136 & 27 & 80 & 82 & 75 \\
\hline $\mathrm{Ba}$ & 6 & 45 & --- & 32 & -- & 25 \\
\hline V & 301 & 404 & 397 & 490 & 328 & 419 \\
\hline $\mathrm{Cr}$ & 160 & 69 & 191 & 62 & 232 & 108 \\
\hline $\mathrm{Ti}$ & 6,774 & 9,592 & 10,132 & 10,371 & 9,292 & 8,753 \\
\hline
\end{tabular}

Major element oxides expressed in weight percent Trace elements expressed in parts per million LOI: loss on ignition

$\mathrm{FeO}^{*}$ : total iron as $\mathrm{FeO}$ 
APPENDIX 2 (cont:)

Chemical Analyses of the Greenstone and Amphibolites

\begin{tabular}{|c|c|c|c|c|c|c|}
\hline Sample & $\begin{array}{l}\text { bgs } \\
219 a \\
\end{array}$ & $\begin{array}{l}\text { bgs } \\
221 \\
\end{array}$ & $\begin{array}{l}\mathrm{bac} \\
250 \\
\end{array}$ & $\begin{array}{l}\text { bac } \\
256 \\
\end{array}$ & $\begin{array}{l}\text { baf } \\
257 \\
\end{array}$ & $\begin{array}{l}\text { bac } \\
260 \\
\end{array}$ \\
\hline $\mathrm{SiO}_{2}$ & 49.10 & 53.66 & 49.21 & 46.67 & 44.90 & 47.39 \\
\hline $\mathrm{TiO}_{2}$ & 1.29 & 1.15 & 0.78 & 0.88 & 0.91 & 0.65 \\
\hline $\mathrm{Al}_{2} \mathrm{O}_{3}$ & 10.68 & 14.20 & 13.20 & 14.12 & 15.80 & 13.83 \\
\hline $\mathrm{Fe}_{2} \mathrm{O}_{3}$ & 4.92 & 4.50 & 5.22 & 4.07 & 5.45 & 4.07 \\
\hline $\mathrm{FeO}$ & 7.35 & 6.00 & 8.06 & 7.82 & 6.17 & 7.07 \\
\hline Mno & 0.22 & 0.26 & 0.19 & 0.20 & 0.20 & 0.22 \\
\hline $\mathrm{MgO}$ & 5.93 & 4.71 & 7.59 & 9.00 & 6.73 & 10.00 \\
\hline $\mathrm{CaO}$ & 8.48 & 5.96 & 8.90 & 10.19 & 13.60 & 7.91 \\
\hline $\mathrm{Na}_{2} \mathrm{O}$ & 0.97 & 5.46 & 1.64 & 2.17 & 1.79 & 2.81 \\
\hline $\mathrm{K}_{2} \mathrm{O}$ & 0.01 & 0.79 & 0.20 & 0.54 & 0.34 & 0.23 \\
\hline $\mathrm{P}_{2} \mathrm{O}_{5}$ & 0.11 & 0.06 & 0.04 & 0.02 & 0.13 & --- \\
\hline LOI & 9.99 & 2.59 & 3.60 & 3.47 & 2.99 & 4.12 \\
\hline Total & 99.05 & 99.34 & 98.63 & 99.15 & 99.01 & 98.30 \\
\hline $\mathrm{FeO}^{*}$ & 11.77 & 10.04 & 12.74 & 11.48 & 11.07 & 10.72 \\
\hline $\mathrm{Fe} 0^{*} / \mathrm{MgO}$ & 1.99 & 2.13 & 1.68 & 1.28 & 1.64 & 1.07 \\
\hline $\mathrm{Nb}$ & 8 & 16 & 9 & 7 & 4 & 9 \\
\hline $\mathrm{Zr}$ & 88 & 201 & 57 & 46 & 62 & 40 \\
\hline$Y$ & 32 & 41 & 31 & 25 & 28 & 28 \\
\hline Sr & 168 & 186 & 60 & 47 & 135 & 40 \\
\hline $\mathrm{Rb}$ & 1 & 37 & 3 & 6 & 6 & 5 \\
\hline $\mathrm{Pb}$ & --- & 3 & --- & --- & -- & -- \\
\hline $\mathrm{Ga}$ & 15 & 23 & 18 & 20 & 19 & 18 \\
\hline $\mathrm{Zn}$ & 315 & 111 & 86 & 103 & 94 & 121 \\
\hline $\mathrm{Ni}$ & 40 & 98 & 73 & 101 & 128 & 83 \\
\hline $\mathrm{Cu}$ & 72 & 22 & 68 & 67 & 261 & 69 \\
\hline $\mathrm{Ba}$ & 16 & 129 & 24 & 61 & 49 & 34 \\
\hline V & 382 & 261 & 335 & 311 & 290 & 283 \\
\hline $\mathrm{Cr}$ & 58 & 93 & 91 & 84 & 151 & 89 \\
\hline $\mathrm{Ti}$ & 7,734 & 6,894 & 4,676 & 5,276 & 5,455 & 3,897 \\
\hline
\end{tabular}

Major element oxides expressed in weight percent Trace elements expressed in parts per million LOI : loss on ignition

$\mathrm{FeO}^{*}$ : total iron as $\mathrm{FeO}$ 
APPENDIX 2 (cont.)

Chemical Analyses of the Greenstone and Amphibolites

\begin{tabular}{|c|c|c|c|c|c|c|}
\hline Sample & $\begin{array}{l}\text { bgs } \\
268 \\
\end{array}$ & $\begin{array}{l}\text { bgs } \\
279 \\
\end{array}$ & $\begin{array}{l}\mathrm{bgs} \\
280 \\
\end{array}$ & $\begin{array}{l}\mathrm{bgs} \\
286 \\
\end{array}$ & $\begin{array}{l}\text { bgs } \\
297 \\
\end{array}$ & $\begin{array}{l}\mathrm{bgs} \\
297 \mathrm{a} \\
\end{array}$ \\
\hline $\mathrm{SiO}_{2}$ & 49.30 & 52.26 & 44.71 & 45.50 & 44.60 & 44.56 \\
\hline $\mathrm{TiO}_{2}$ & 1.27 & 1.52 & 1.60 & 0.85 & 0.71 & 0.40 \\
\hline $\mathrm{Al}_{2} \mathrm{O}_{3}$ & 14.44 & 11.77 & 12.25 & 15.20 & 13.10 & 14.09 \\
\hline $\mathrm{Fe}_{2} \mathrm{O}_{3}$ & 8.78 & 9.78 & 9.58 & 3.95 & 9.24 & 6.01 \\
\hline $\mathrm{Fe} 0$ & 5.61 & 4.97 & 5.13 & 5.06 & 3.93 & 3.90 \\
\hline MnO & 0.20 & 0.19 & 0.25 & 0.15 & 0.17 & 0.16 \\
\hline MgO & 5.11 & 3.83 & 4.92 & 8.40 & 7.00 & 8.37 \\
\hline $\mathrm{CaO}$ & 7.98 & 11.55 & 11.95 & 12.67 & 11.76 & 12.14 \\
\hline $\mathrm{Na}_{2} \mathrm{O}$ & 2.28 & 1.84 & 2.37 & 1.73 & 0.12 & 0.36 \\
\hline $\mathrm{K}_{2} \mathrm{O}$ & 0.13 & 0.07 & 1.03 & 0.03 & --- & -- \\
\hline $\mathrm{P}_{2} \mathrm{O}_{5}$ & 0.15 & 0.09 & 0.14 & 0.08 & 0.10 & 0.03 \\
\hline LOI & 4.22 & 2.13 & 4.46 & 4.39 & 8.38 & 9.44 \\
\hline Total & 99.43 & 100.00 & 98.39 & 98.01 & 99.11 & 99.46 \\
\hline $\mathrm{Fe} 0^{*}$ & 13.50 & 14.13 & 13.75 & 8.60 & 12.24 & 9.31 \\
\hline $\mathrm{FeO} / / \mathrm{MgO}$ & 2.64 & 3.60 & 2.80 & 1.02 & 1.75 & 1.11 \\
\hline $\mathrm{Nb}$ & 21 & 10 & 11 & -.. & 8 & 6 \\
\hline $\mathrm{Zr}$ & 224 & 99 & 98 & --- & 70 & 37 \\
\hline$Y$ & 44 & 41 & 44 & -.- & 30 & 23 \\
\hline $\mathrm{Sr}$ & 211 & 113 & 114 & --- & 95 & 105 \\
\hline $\mathrm{Rb}$ & 4 & 7 & 30 & -- & 2 & 2 \\
\hline $\mathrm{Pb}$ & 11 & 1 & -- & --- & 6 & 2 \\
\hline $\mathrm{Ga}$ & 21 & 21 & 20 & -- & 17 & 15 \\
\hline $\mathrm{Zn}$ & 116 & 97 & 134 & --- & 117 & 87 \\
\hline $\mathrm{Ni}$ & 68 & 61 & 84 & -- & 147 & 136 \\
\hline $\mathrm{Cu}$ & 112 & 28 & 94 & --- & 97 & 36 \\
\hline $\mathrm{Ba}$ & 44 & 14 & 134 & --- & 2 & --- \\
\hline V & 358 & 439 & 395 & -- & 345 & 243 \\
\hline $\mathrm{Cr}$ & 82 & 91 & 105 & --- & 244 & 321 \\
\hline $\mathrm{Ti}$ & 7,614 & 9,352 & 9,592 & -.- & 4,256 & 2,398 \\
\hline
\end{tabular}

Major element oxides expressed in weight percent

Trace elements expressed in parts per million

LOI: loss on ignition

$\mathrm{Fe} 0^{*}$ : total iron as $\mathrm{FeO}$ 
APPENDIX 2 (cont.)

Chemical Analyses of the Creenstone and Amphibolites

\begin{tabular}{|c|c|c|c|c|c|c|}
\hline Sample & $\begin{array}{l}\text { bgs } \\
298 \\
\end{array}$ & $\begin{array}{l}\text { bgs } \\
300 \\
\end{array}$ & $\begin{array}{l}\text { baf } \\
305 \\
\end{array}$ & $\begin{array}{l}\text { baf } \\
308 \\
\end{array}$ & $\begin{array}{l}\mathrm{bac} \\
309 \\
\end{array}$ & $\begin{array}{l}\text { bac } \\
310 \\
\end{array}$ \\
\hline $\mathrm{SiO}_{2}$ & 46.62 & 46.80 & 48.96 & -- & 40.90 & 42.09 \\
\hline $\mathrm{TiO}_{2}$ & 1.03 & 1.00 & 0.90 & --- & 0.85 & 1.02 \\
\hline $\mathrm{Al}_{2} \mathrm{O}_{3}$ & 14.17 & 14.40 & 13.91 & -- & 17.83 & 13.83 \\
\hline $\mathrm{Fe}_{2} \mathrm{O}_{3}$ & 4.47 & 4.81 & 3.52 & -- & 2.20 & 5.62 \\
\hline $\mathrm{FeO}$ & 6.53 & 5.34 & 7.78 & -- & 12.05 & 7.82 \\
\hline Mno & 0.18 & 0.16 & 0.21 & --- & 0.21 & 0.21 \\
\hline $\mathrm{MgO}$ & 8.39 & 8.27 & 8.07 & --- & 8.95 & 10.37 \\
\hline $\mathrm{CaO}$ & 11.12 & 12.75 & 10.42 & --- & 8.77 & 12.09 \\
\hline $\mathrm{Na}_{2} \mathrm{O}$ & 2.13 & 1.82 & 2.48 & --- & 1.95 & 1.79 \\
\hline $\mathrm{K}_{2} \mathrm{O}$ & 0.03 & 0.04 & 0.11 & -- & 0.11 & 0.25 \\
\hline $\mathrm{P}_{2} \mathrm{O}_{5}$ & 0.09 & 0.11 & 0.09 & -- & -- & -- \\
\hline LOI & 3.78 & 3.16 & 4.13 & --- & 6.05 & 3.49 \\
\hline Total & 98.54 & 98.66 & 100.58 & -- & 99.87 & 98.58 \\
\hline $\mathrm{FeO}^{*}$ & 10.54 & 9.67 & 10.17 & --- & 14.02 & 12.87 \\
\hline $\mathrm{FeO} / \mathrm{MgO}$ & 1.26 & 1.69 & 1.26 & --- & 1.57 & 1.24 \\
\hline $\mathrm{Nb}$ & 9 & 7 & 9 & 9 & 4 & 6 \\
\hline $\mathrm{Zr}$ & 65 & 56 & 59 & 65 & 57 & 49 \\
\hline$Y$ & 29 & 27 & 25 & 33 & 34 & 33 \\
\hline $\mathrm{Sr}$ & 91 & 103 & 72 & 78 & 126 & 66 \\
\hline $\mathrm{Rb}$ & -- & -- & 7 & 5 & 6 & 4 \\
\hline $\mathrm{Pb}$ & -- & -- & -- & 5 & 2 & 1 \\
\hline $\mathrm{Ga}$ & 20 & 23 & 16 & 21 & 25 & 21 \\
\hline $\mathrm{Zn}$ & 81 & 71 & 80 & 118 & 117 & 114 \\
\hline $\mathrm{Ni}$ & 74 & 90 & 73 & 67 & 105 & 122 \\
\hline $\mathrm{Cu}$ & 46 & 34 & 170 & 129 & 142 & 60 \\
\hline $\mathrm{Ba}$ & 1 & 16 & 28 & 77 & 26 & 32 \\
\hline V & 300 & 283 & 268 & 313 & 426 & 348 \\
\hline $\mathrm{Cr}$ & 140 & 106 & 96 & 80 & 94 & 112 \\
\hline $\mathrm{Ti}$ & 6,175 & 5,995 & 5,396 & $* *$ & 5,096 & 6,115 \\
\hline
\end{tabular}

Major element oxides expressed in weight percent

Trace elements expressed in parts per million

LOI: loss on ignition

$\mathrm{FeO}^{*}$ : total iron as $\mathrm{FeO}$

**: value not determined 
APPENDIX 2 (cont.)

Chemical Analyses of the Greenstone and Amphibolites

\begin{tabular}{|c|c|c|c|c|c|c|}
\hline Sample & $\begin{array}{l}\text { bgs } \\
314 \\
\end{array}$ & $\begin{array}{l}\text { bgs } \\
315 \\
\end{array}$ & $\begin{array}{l}\text { bgs } \\
319 \\
\end{array}$ & $\begin{array}{l}\text { bgs } \\
321 \\
\end{array}$ & $\begin{array}{l}\text { bgs } \\
325 \\
\end{array}$ & $\begin{array}{l}\text { bgs } \\
329 \\
\end{array}$ \\
\hline $\mathrm{SiO}_{2}$ & 45.82 & 46.20 & 44.93 & 44.03 & 47.00 & 49.30 \\
\hline $\mathrm{TiO}_{2}$ & 1.11 & 1.20 & 1.04 & 1.04 & 1.44 & 0.67 \\
\hline $\mathrm{Al}_{2} \mathrm{O}_{3}$ & 14.83 & 14.10 & 13.42 & 14.42 & 14.70 & 14.60 \\
\hline $\mathrm{Fe}_{2} \mathrm{O}_{3}$ & 4.39 & 5.70 & 3.57 & 3.22 & 7.67 & 3.72 \\
\hline $\mathrm{FeO}$ & 7.51 & 4.23 & 6.03 & 8.08 & 5.44 & 6.52 \\
\hline $\mathrm{MnO}$ & 0.23 & 0.20 & 0.18 & 0.18 & 0.20 & 0.30 \\
\hline $\mathrm{MgO}$ & 8.21 & 7.60 & 7.59 & 9.24 & 6.39 & 9.21 \\
\hline $\mathrm{CaO}$ & 9.22 & 7.11 & 7.84 & 7.67 & 11.32 & 7.61 \\
\hline $\mathrm{Na}_{2} \mathrm{O}$ & 2.40 & 2.85 & 3.09 & 3.02 & 2.45 & 2.63 \\
\hline $\mathrm{K}_{2} \mathrm{O}$ & 0.21 & 0.03 & 0.02 & 0.02 & 0.44 & 0.09 \\
\hline $\mathrm{P}_{2} \mathrm{O}_{5}$ & 0.02 & 0.11 & 0.01 & --- & 0.10 & 0.09 \\
\hline LOI & 4.84 & 10.44 & 10.30 & 7.82 & 3.33 & 4.79 \\
\hline Total & 98.29 & 99.77 & 98.02 & 98.74 & 100.48 & 99.53 \\
\hline $\mathrm{FeO} *$ & 11.46 & 9.36 & 9.24 & 11.06 & 12.33 & 9.86 \\
\hline $\mathrm{FeO} / \mathrm{MgO}$ & 1.40 & 1.23 & 1.22 & 1.20 & 1.93 & 1.07 \\
\hline $\mathrm{Nb}$ & 8 & 9 & 8 & 7 & 10 & 9 \\
\hline $\mathrm{Zr}$ & 75 & 82 & 69 & 62 & 86 & 44 \\
\hline$Y$ & 33 & 31 & 24 & 34 & 36 & 19 \\
\hline $\mathrm{Sr}$ & 89 & 113 & 138 & 79 & 127 & 227 \\
\hline $\mathrm{Rb}$ & 4 & -.- & --- & 2 & 12 & 1 \\
\hline $\mathrm{Pb}$ & 8 & -- & 6 & 2 & 3 & -- \\
\hline $\mathrm{Ga}$ & 21 & 21 & 13 & 20 & 18 & 20 \\
\hline $\mathrm{Zn}$ & 91 & 126 & 109 & 90 & 106 & 385 \\
\hline $\mathrm{Ni}$ & 98 & 99 & 122 & 110 & 88 & 104 \\
\hline $\mathrm{Cu}$ & 86 & 178 & 72 & 37 & 33 & 78 \\
\hline $\mathrm{Ba}$ & 45 & 30 & 17 & -- & 72 & 9 \\
\hline V & 305 & 309 & 304 & 374 & 367 & 280 \\
\hline $\mathrm{Cr}$ & 186 & 225 & 346 & 187 & 247 & 202 \\
\hline $\mathrm{Ti}$ & 6,654 & 7,194 & 6,235 & 6,235 & 8,633 & 4,017 \\
\hline
\end{tabular}

Major element oxides expressed in weight percent Trace elements expressed in parts per miliion LOI: 1 loss on ignition

FeO*: total iron as $\mathrm{FeO}$ 


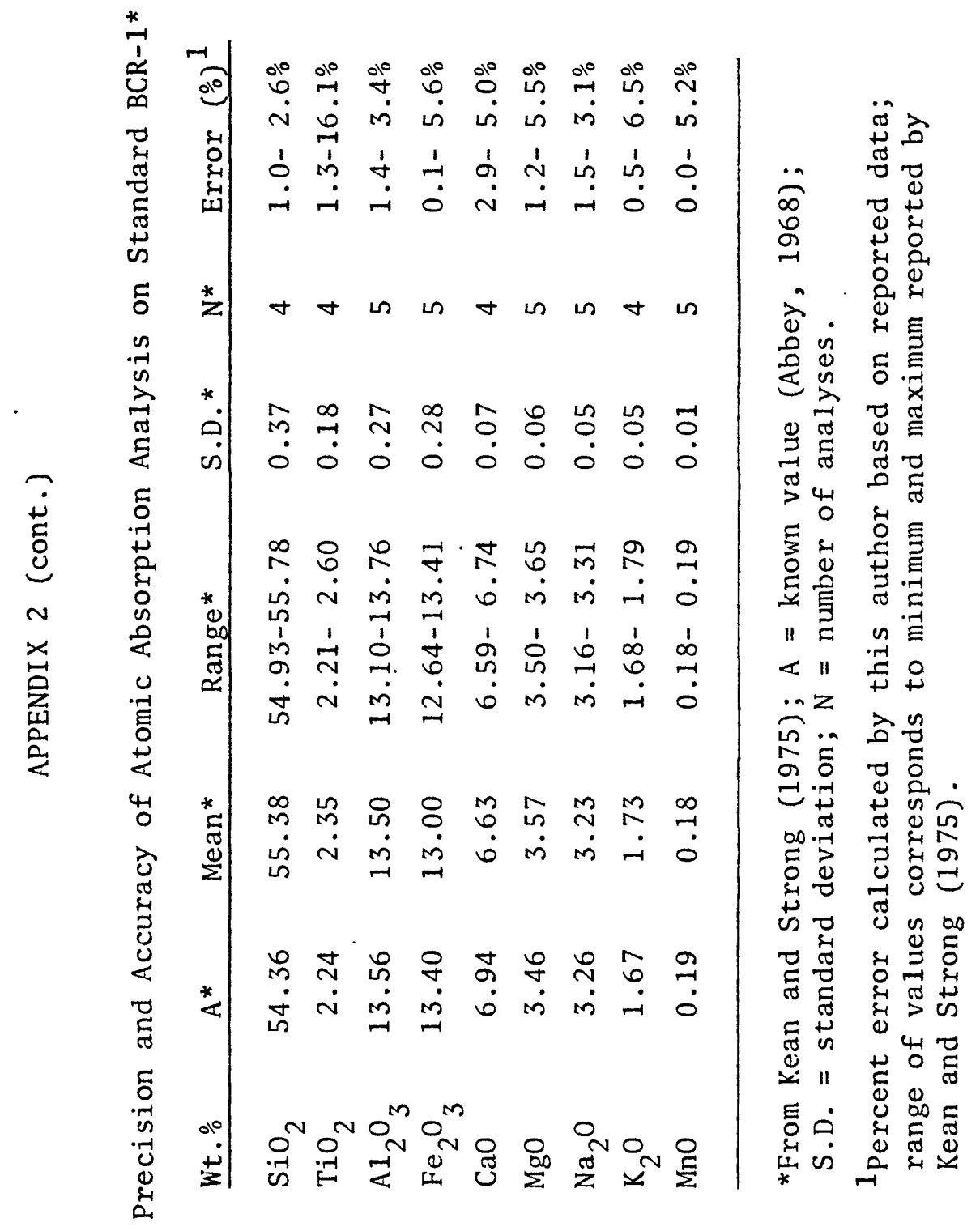




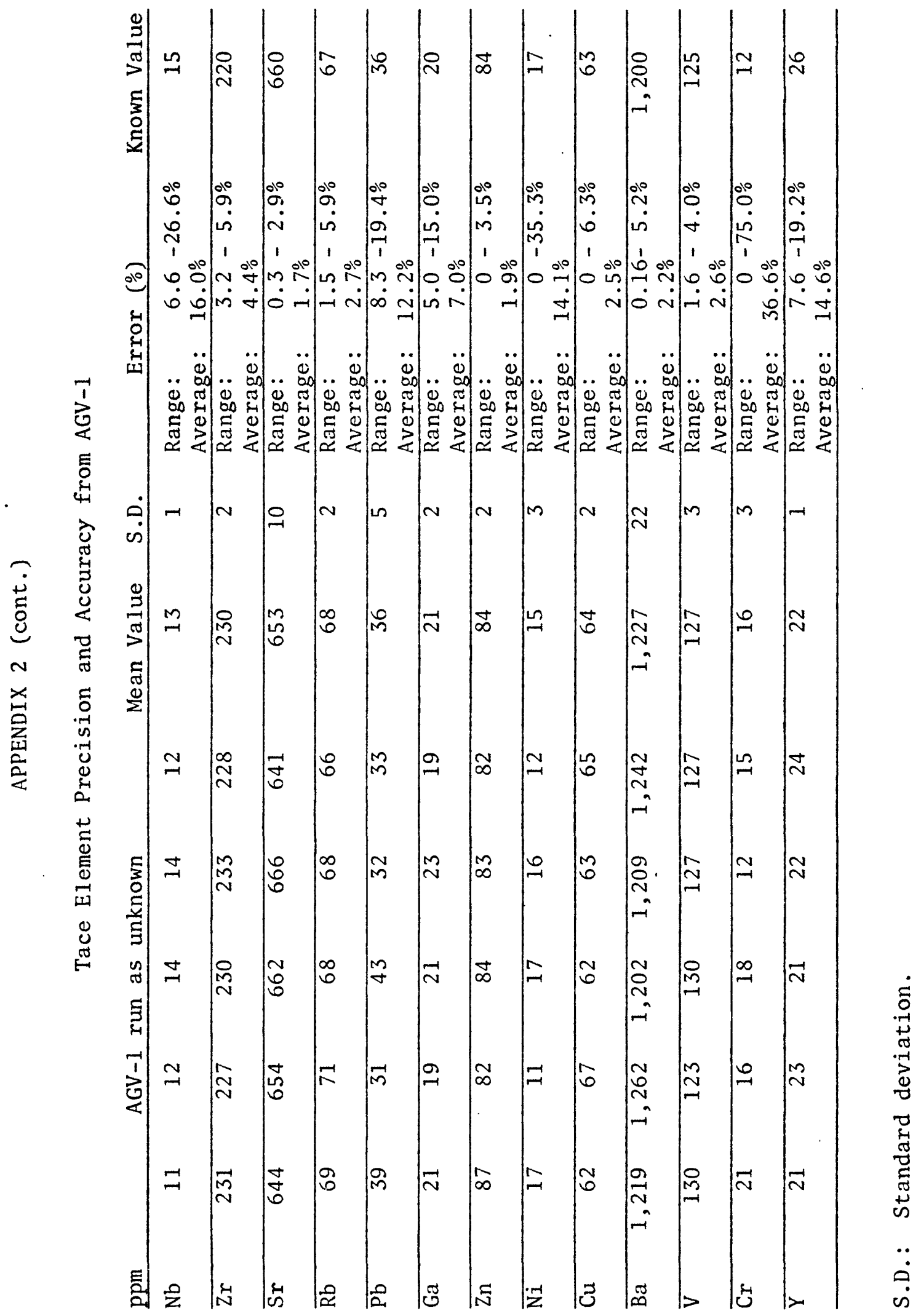




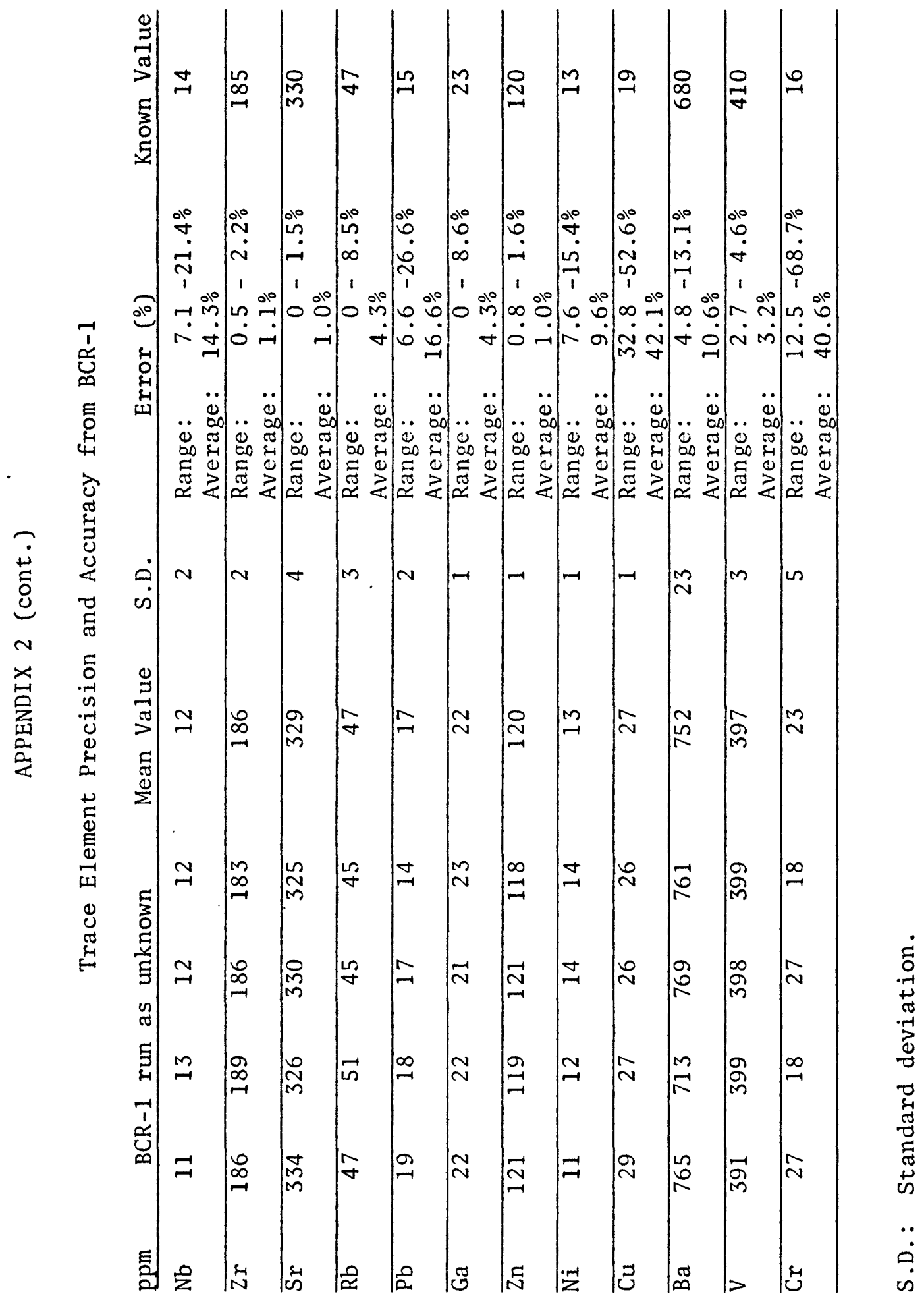




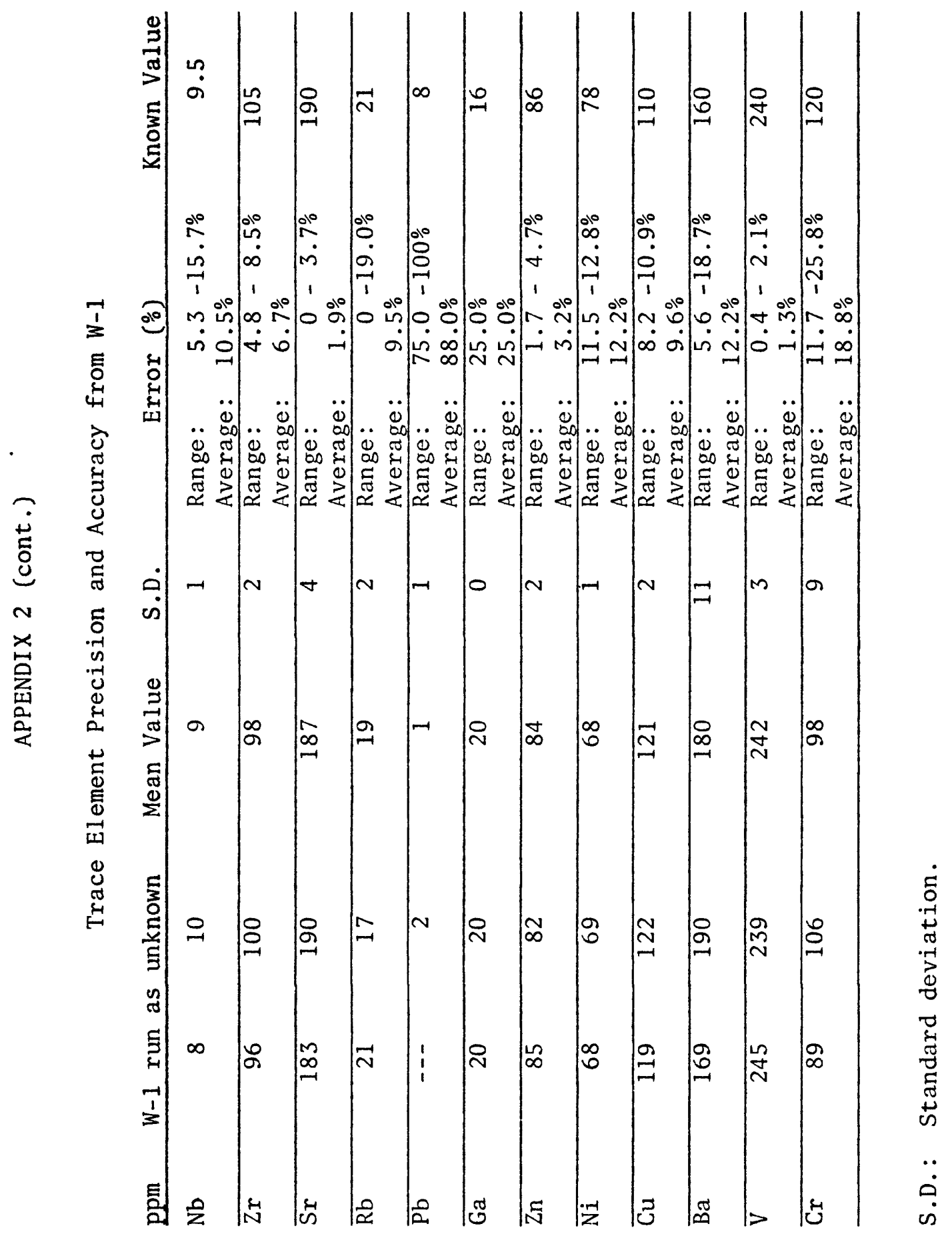


APPENDIX 2 (cont.)

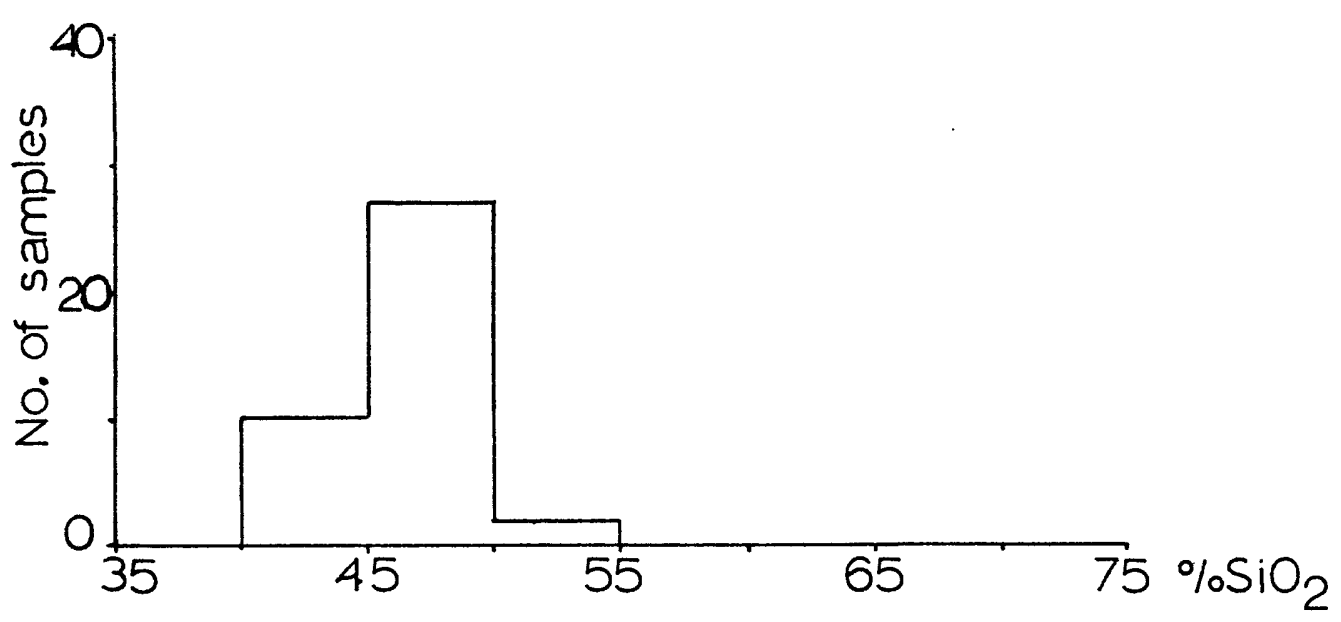

Frequency distribution of $\mathrm{SiO}_{2}$ in the greenstone and amphibolites. Range of values: 40.9-53.66.

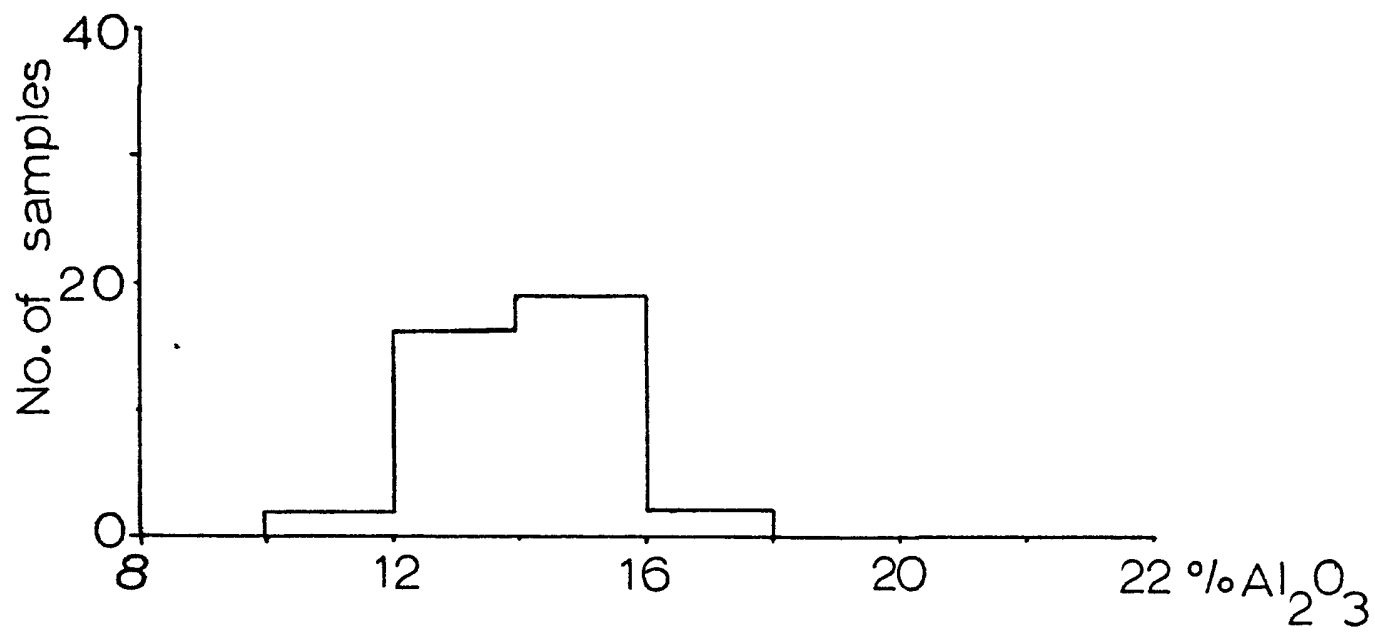

Frequency distribution of $\mathrm{Al}_{2} \mathrm{O}_{3}$ in the greenstone and amphibolites. Range of values: $10.68-17.83$. 
APPENDIX 2 (cont.)

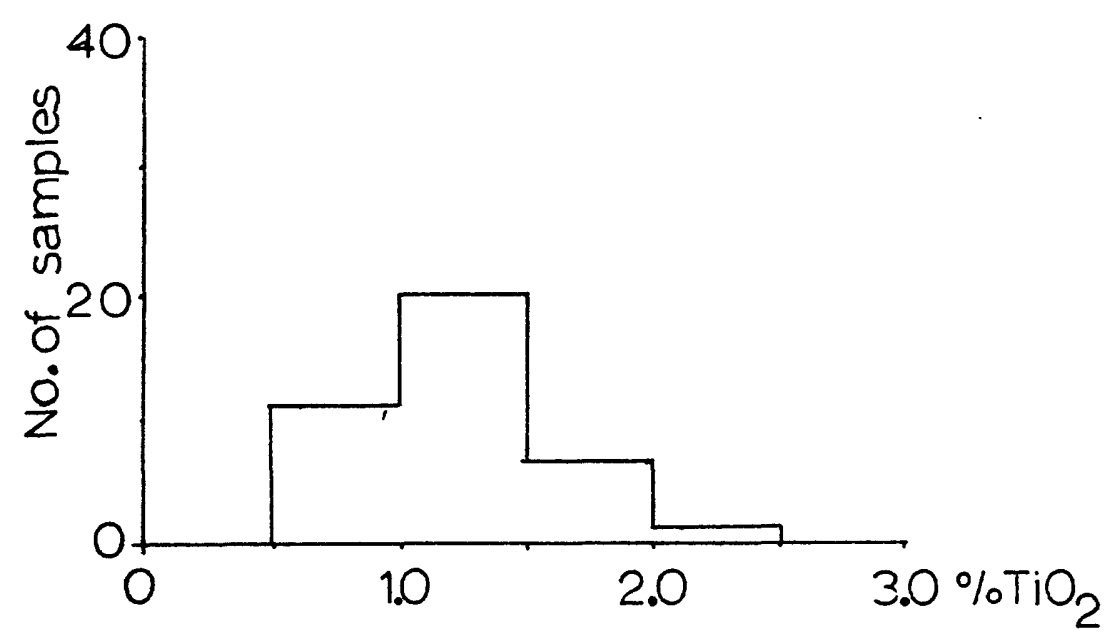

Frequency distribution of $\mathrm{TiO}_{2}$ in the greenstone and amphibolites. Range of values: $0.65-2.43$.

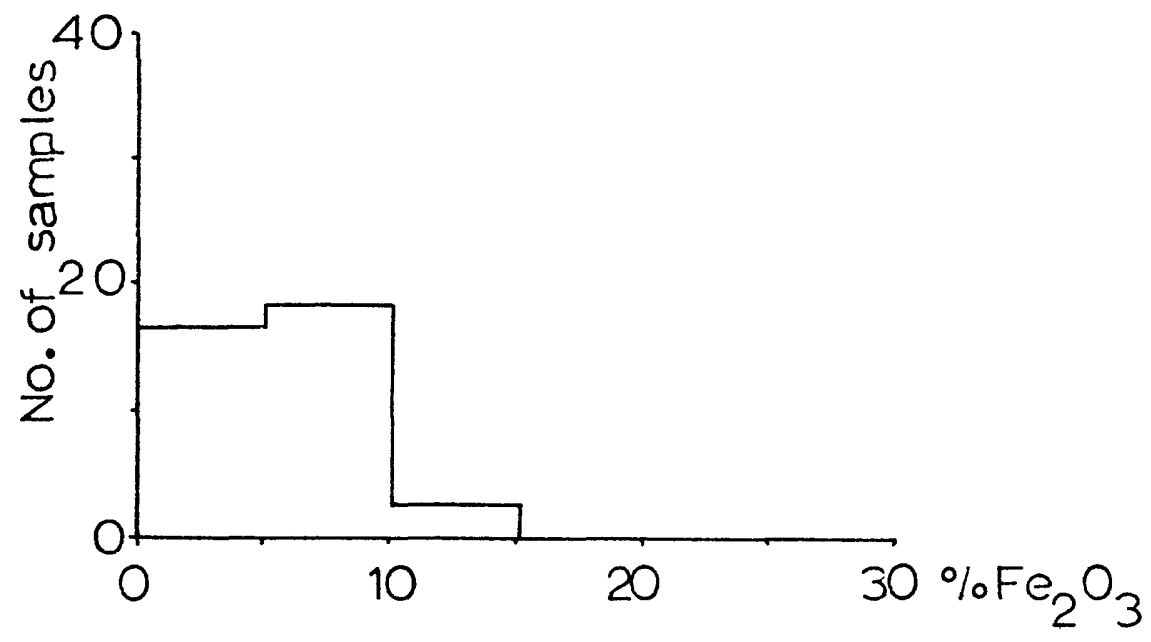

Frequency distribution of $\mathrm{Fe}_{2} \mathrm{O}_{3}$ in the greenstone and amphibolites. Range of values: $2.20-12.69$. 
APPENDIX 2 (cont.)

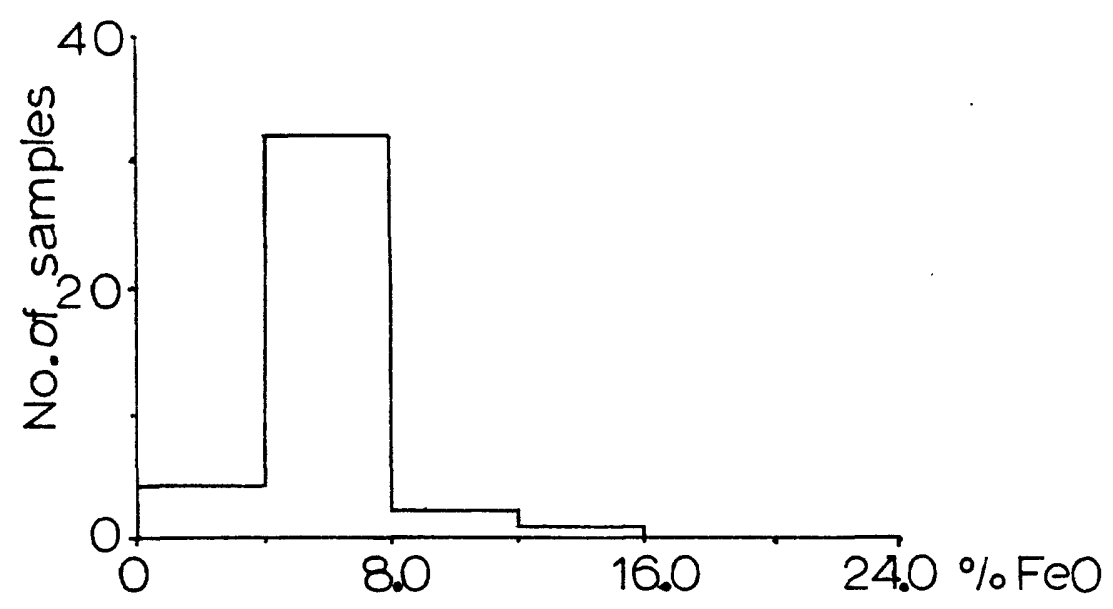

Frequency distribution of $\mathrm{FeO}$ in the greenstone and amphibolites. Range of values: 2.04-12.05.

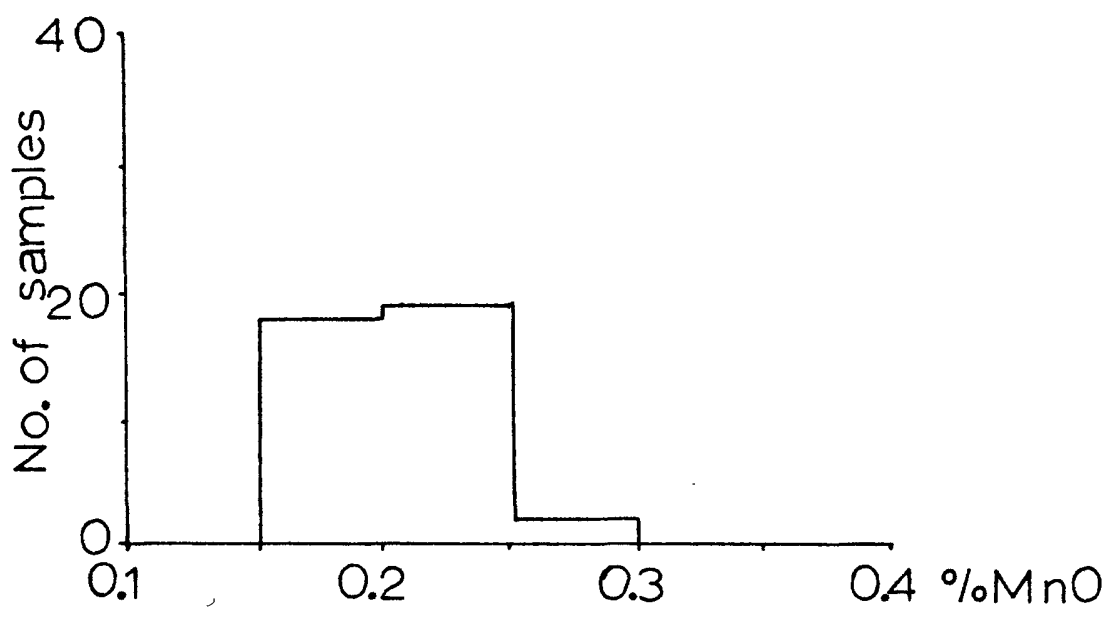

Frequency distribution of $\mathrm{MnO}$ in the greenstone and amphibolites. Range of values: $0.15-0.27$. 
APPENDIX 2 (cont.)

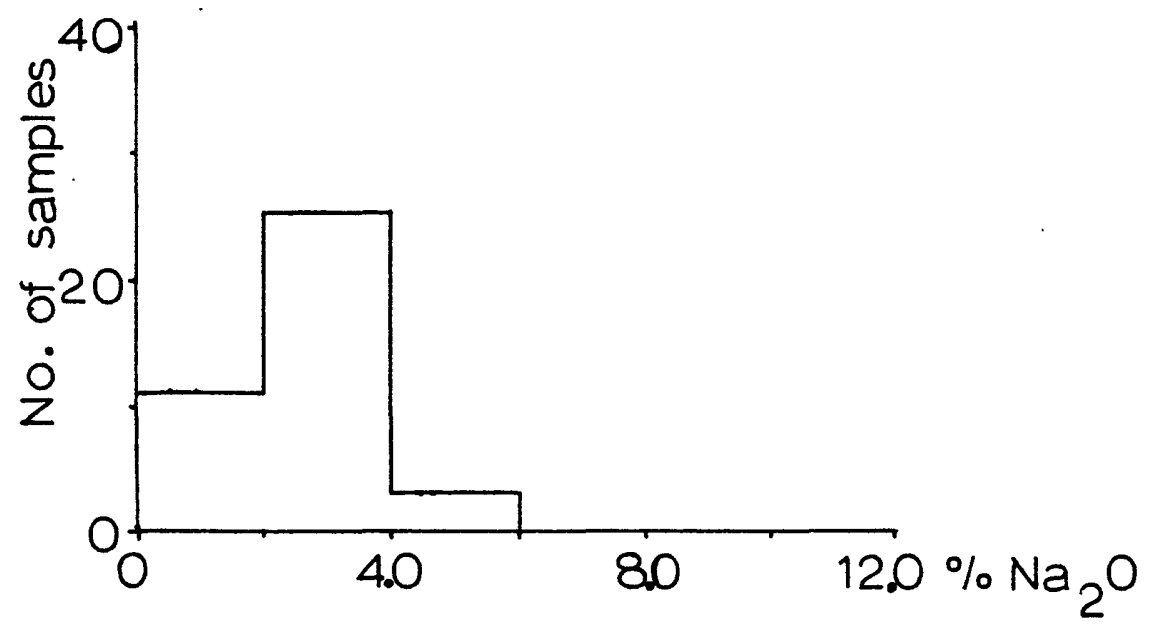

Frequency distribution of $\mathrm{Na}_{2} \mathrm{O}$ in the greenstone and amphibolites. Range of values: $0.97-5.46$.

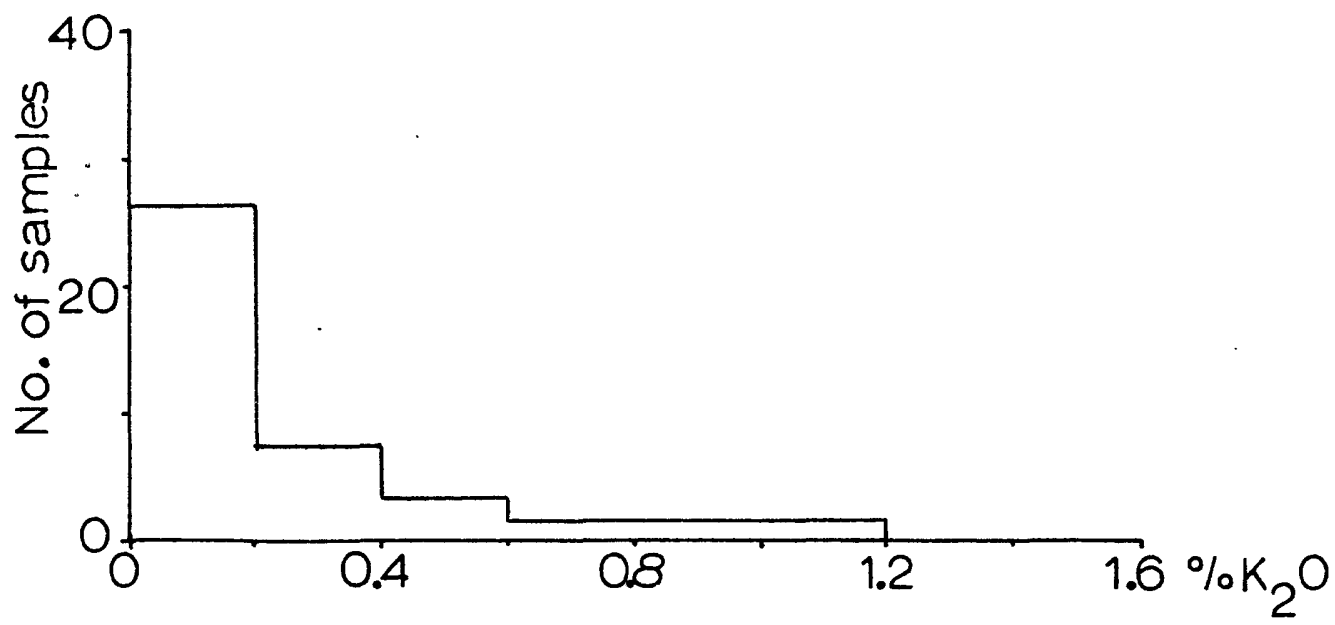

Frequency distribution of $\mathrm{K}_{2} \mathrm{O}$ in the greenstone and amphibolites. Range of values: $0.01-1.03$. 
APPENDIX 2 (cont.)

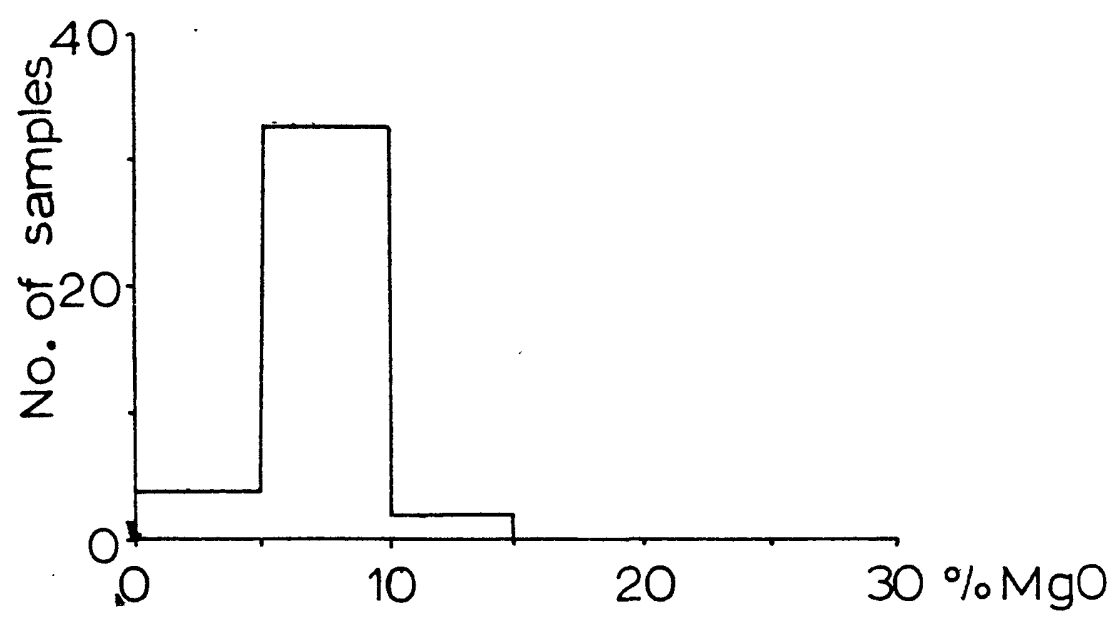

Frequency distribution of $\mathrm{MgO}$ in the greenstone and amphibolites. Range of values: $3.63-10.37$.

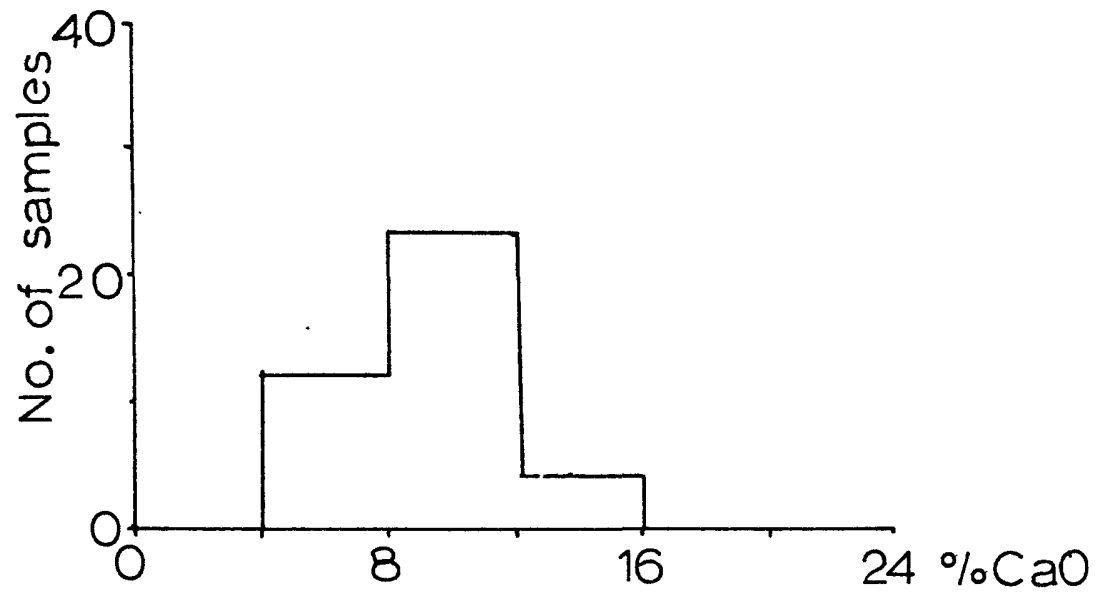

Frequency distribution of $\mathrm{CaO}$ in the greenstone and amphibolites. Range of values: 5.65-15.02. 
APPENDIX 2 (cont.)

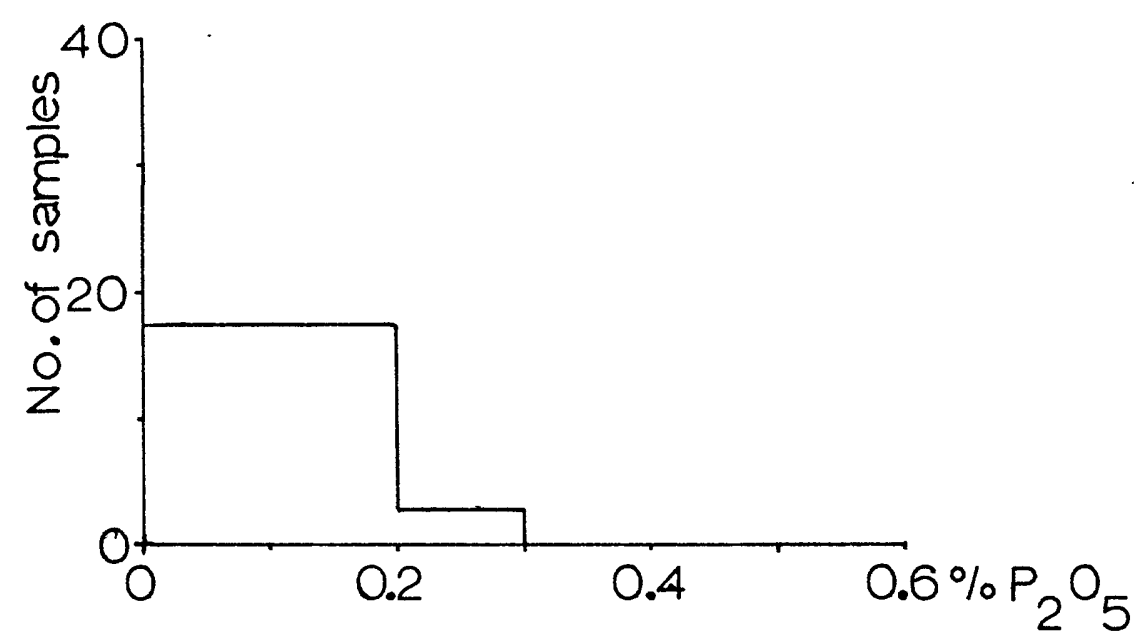

Frequency distribution of $\mathrm{P}_{2} \mathrm{O}_{5}$ in the greenstone and amphibolites. Range of values: $0-0.23$.

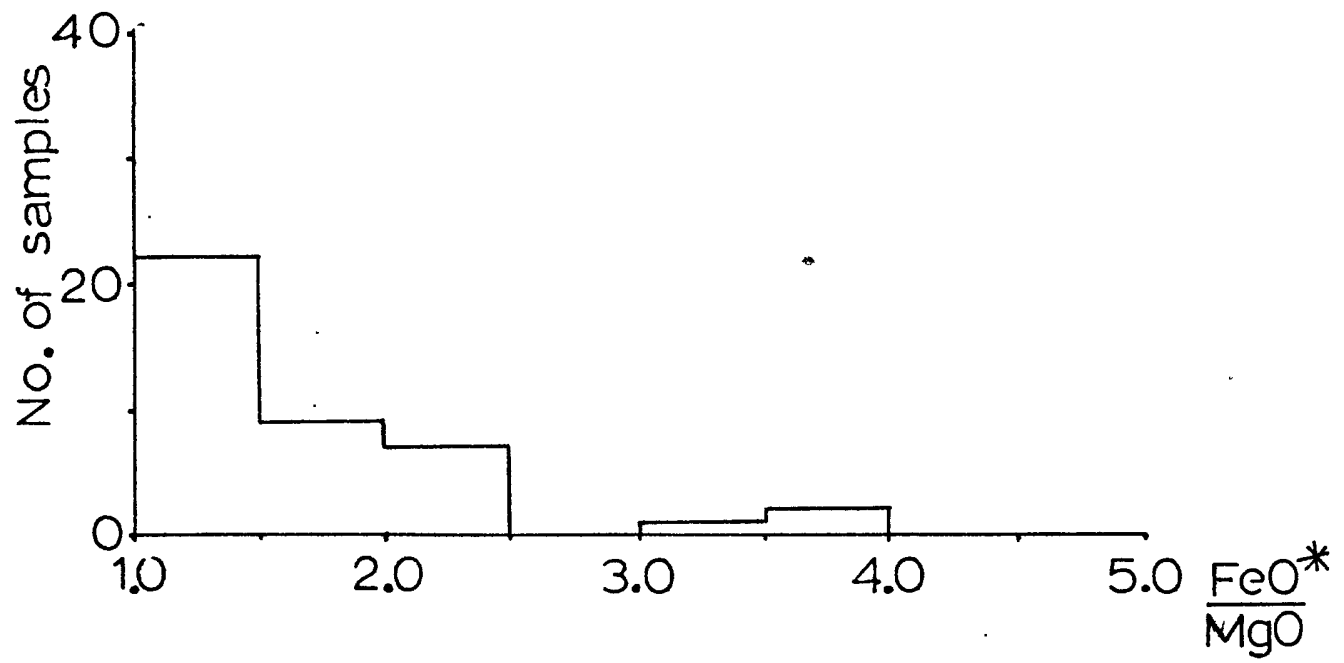

Frequency distribution of $\mathrm{FeO} / \mathrm{MgO}$ in the greenstone and amphibolites. Range of values: $1.02-3.60$. 
APPENDIX 2 (cont.)

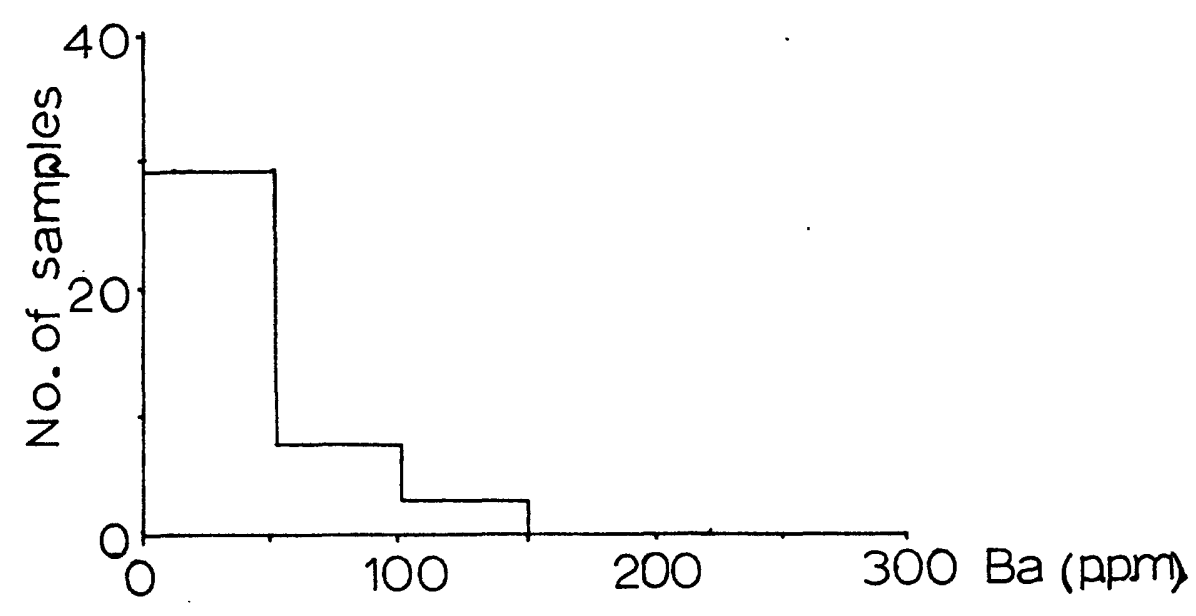

Frequency distribution of $\mathrm{Ba}$ in the greenstone and amphibolites. Range of values: $0-134 \mathrm{ppm}$.

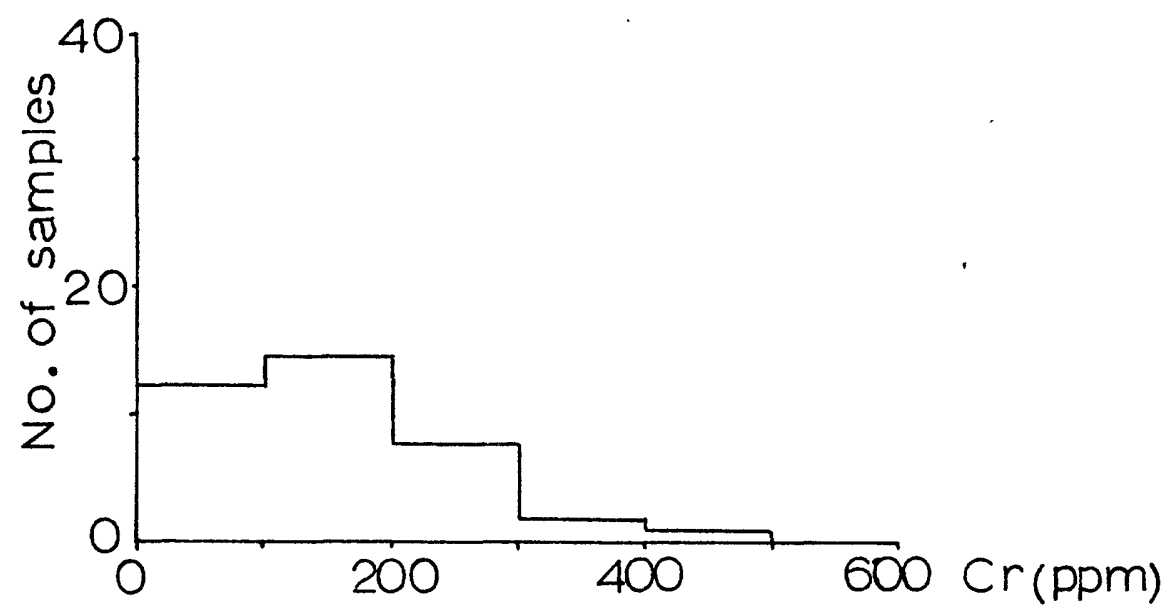

Frequency distribution of $\mathrm{Cr}$ in the greenstone and amphibolites. Range of values: $24-433 \mathrm{ppm}$. 
APPENDIX 2 (cont.)

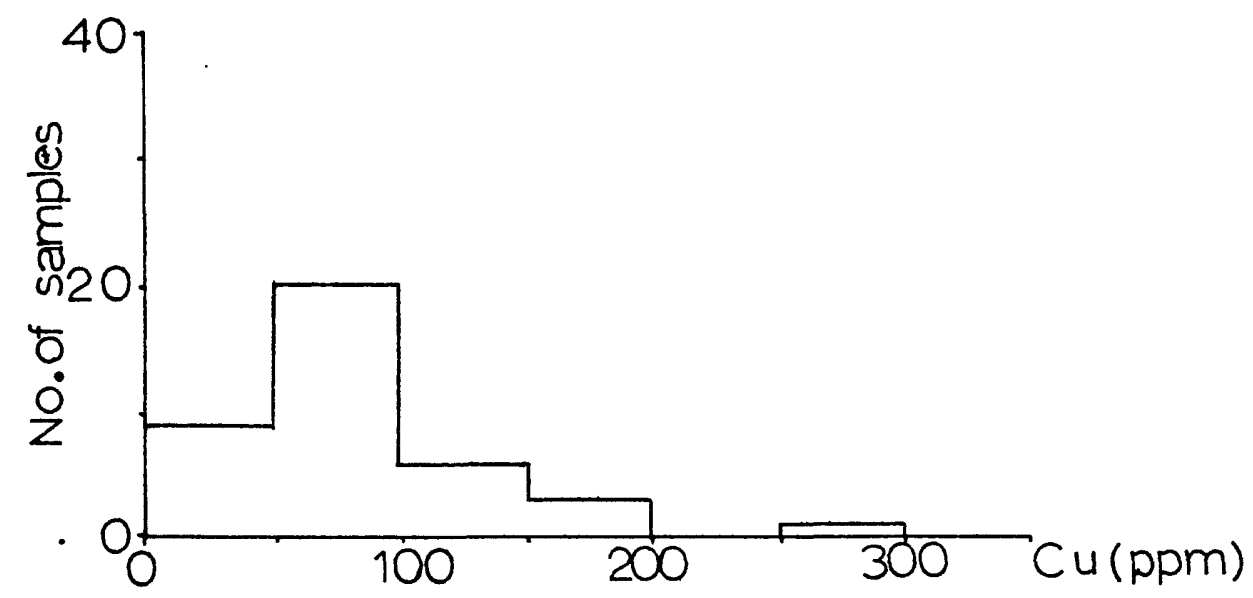

Frequency distribution of $\mathrm{Cu}$ in the greenstone and amphibolites. Range of values: 27-261 ppm.

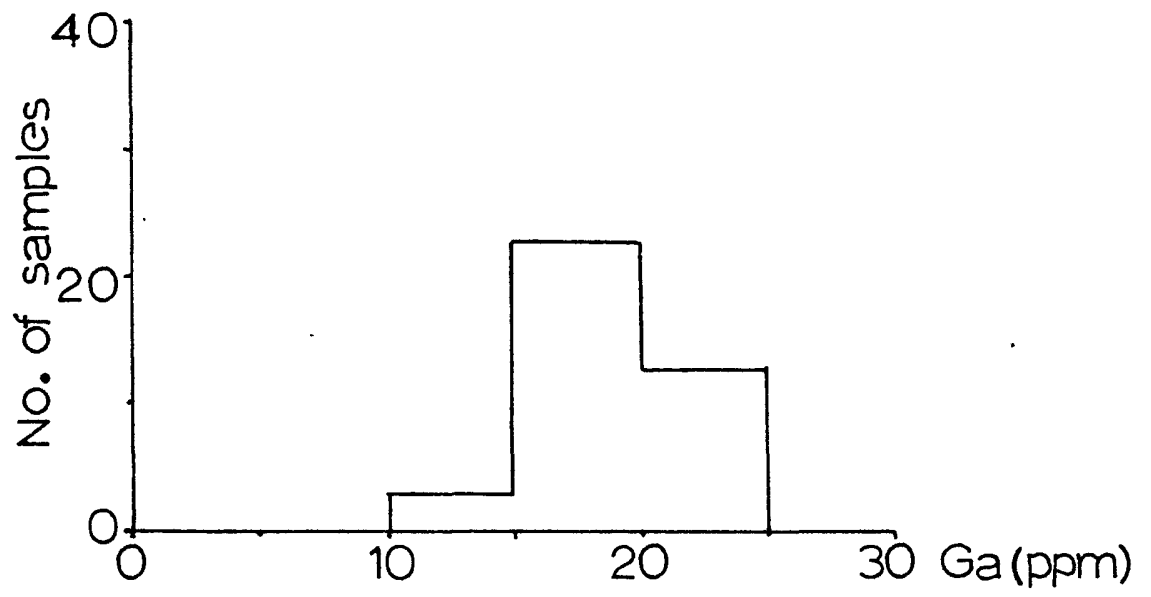

Frequency distribution of $\mathrm{Ga}$ in the greenstone and amphibolites. Range of values: $13-23 \mathrm{ppm}$. 
APPENDIX 2 (cont.)

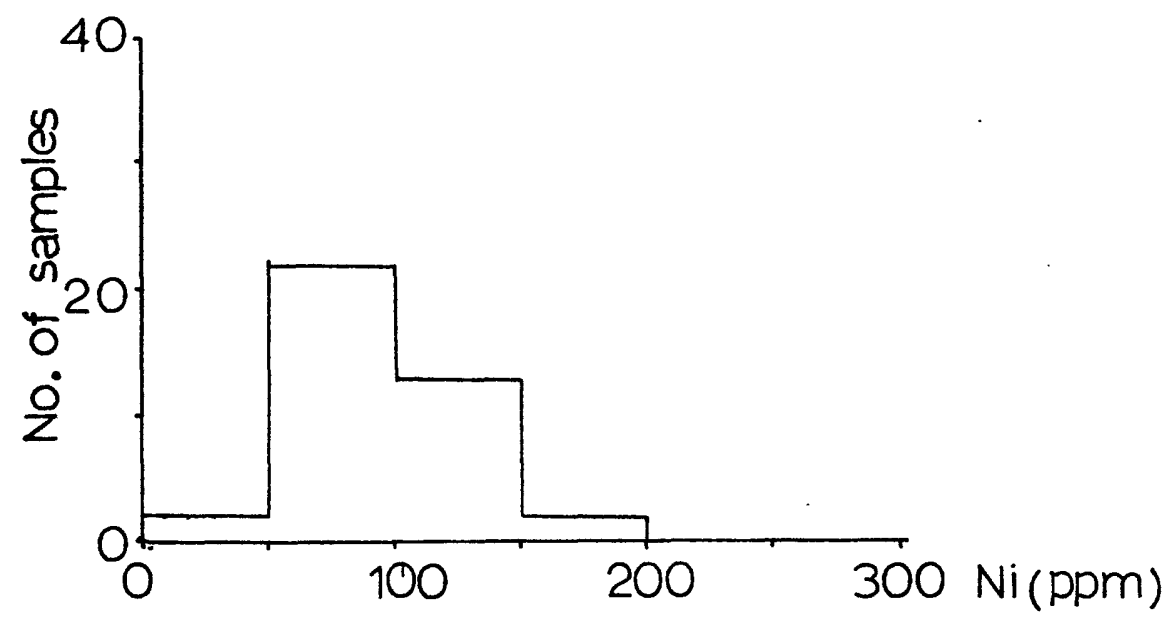

Frequency distribution of $\mathrm{Ni}$ in the greenstone and amphibolites. Range of values: 35-79 ppm.

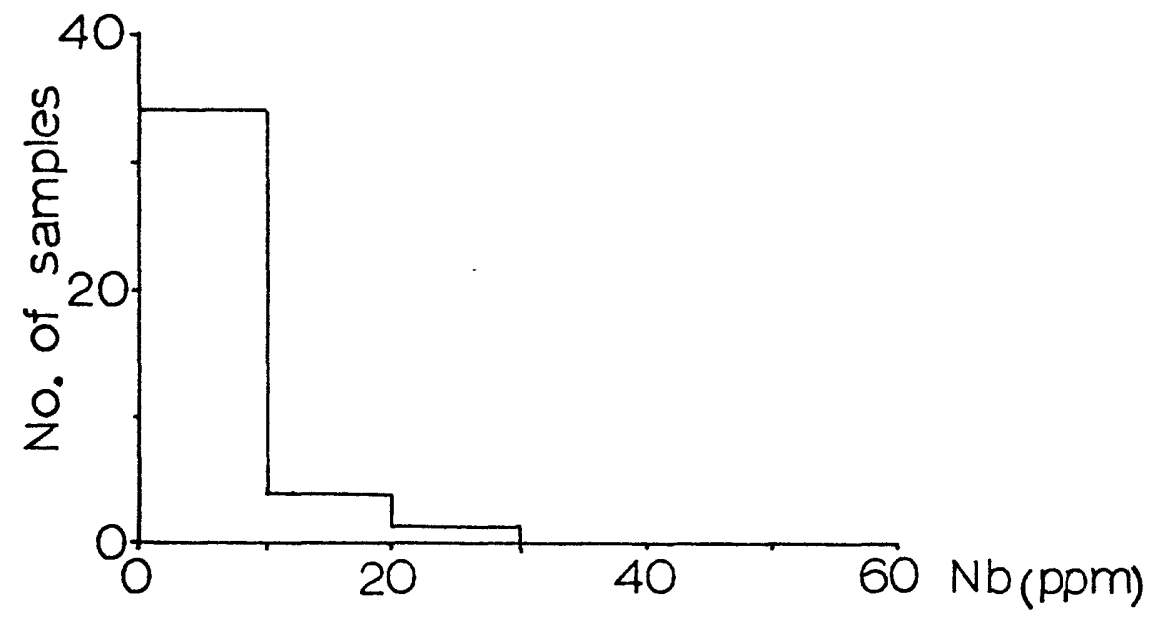

Frequency distribution of $\mathrm{Nb}$ in the greenstone and amphibolites. Range of values: 4-21 ppm. 
APPENDIX 2 (cont.)

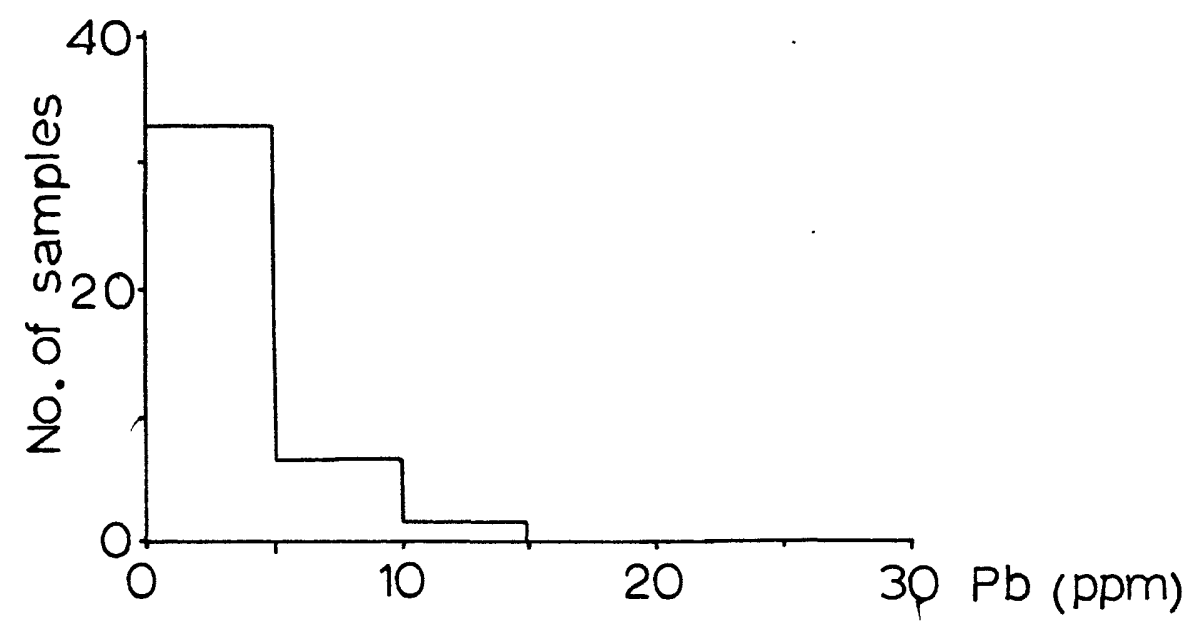

Frequency distribution of $\mathrm{Pb}$ in the greenstone and amphibolites. Range of values: $0-11 \mathrm{ppm}$.

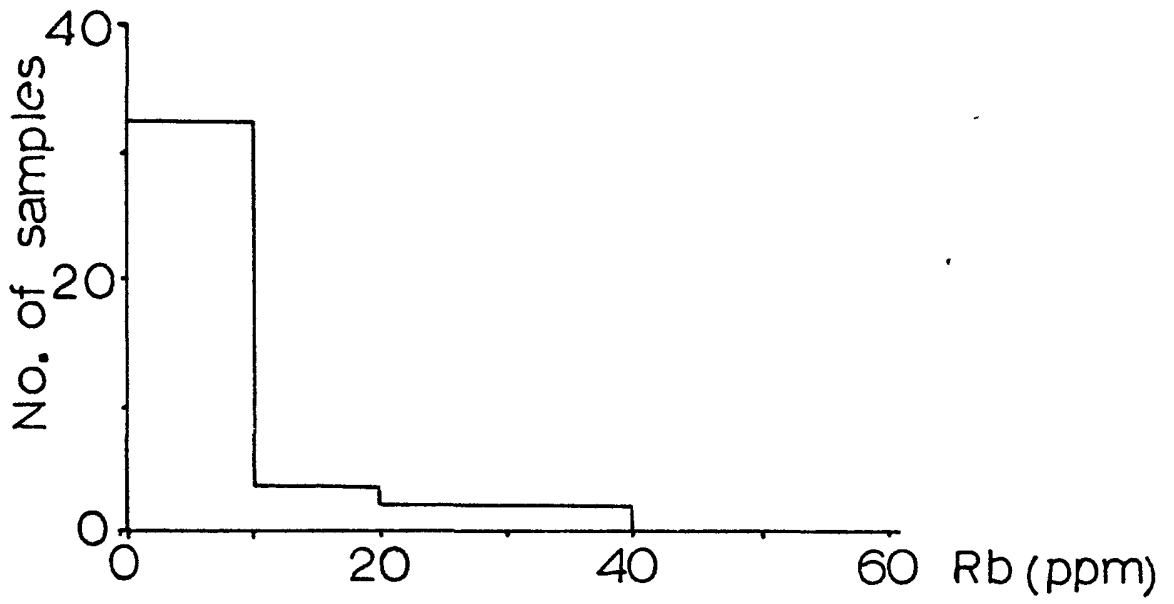

Frequency distribution of $\mathrm{Rb}$ in the greenstone and amphibolites. Range of values: $0-38 \mathrm{ppm}$. 
APPENDIX 2 (cont.)

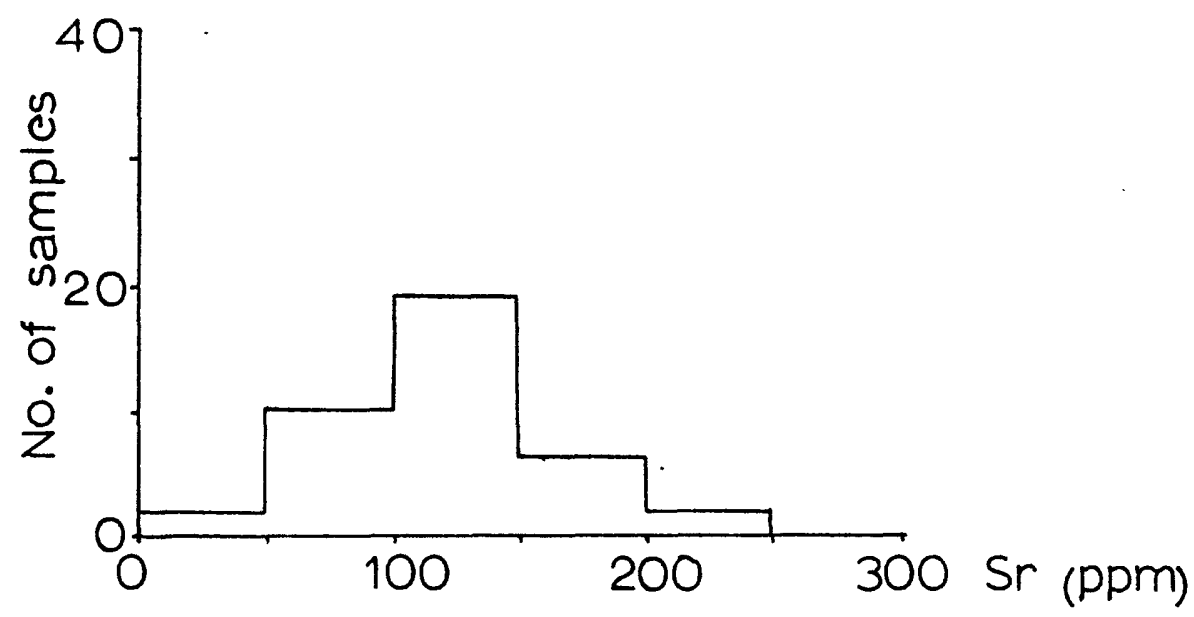

Frequency distribution of $\mathrm{Sr}$ in the greenstone and amphibolites. Range of values: $40-227 \mathrm{ppm}$.

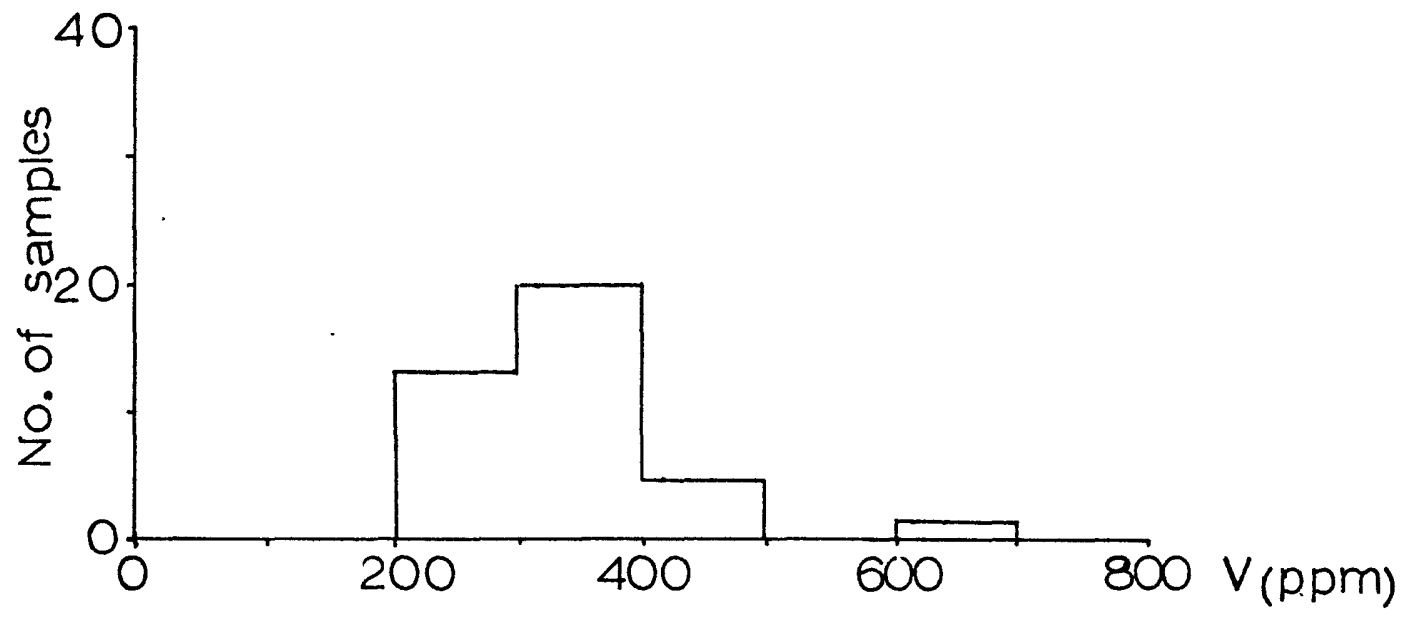

Frequency distribution of $\mathrm{V}$ in the greenstone and amphibolites. Range of values: $243-668 \mathrm{ppm}$. 
APPENDIX 2 (cont.)

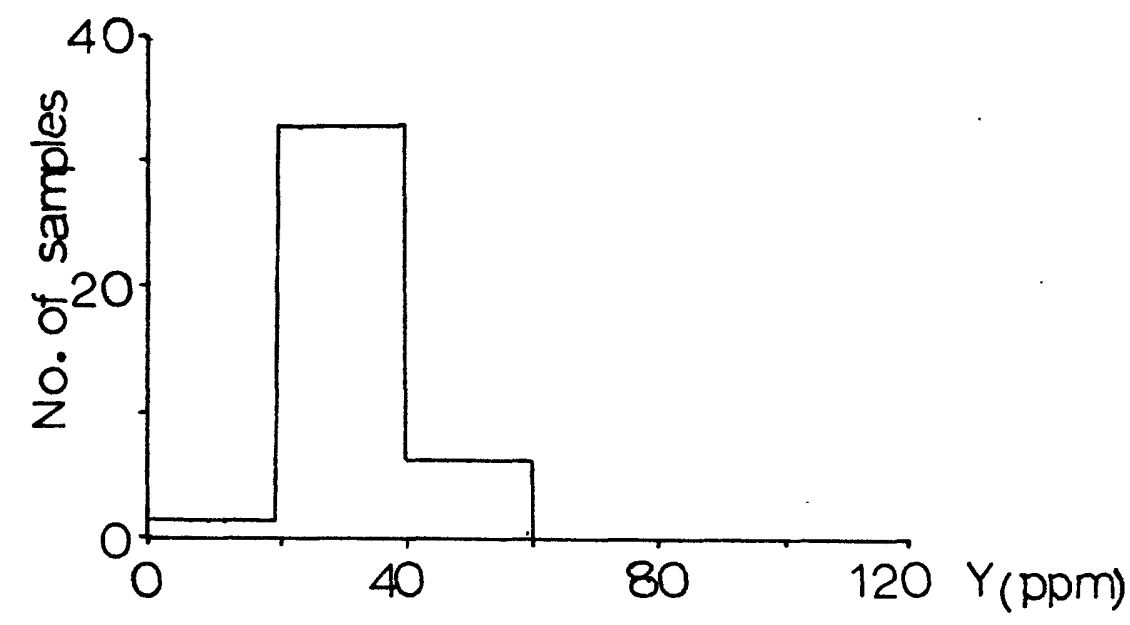

Frequency distribution of $Y$ in the greenstone and amphibolites. Range of values: 19-58 ppm.

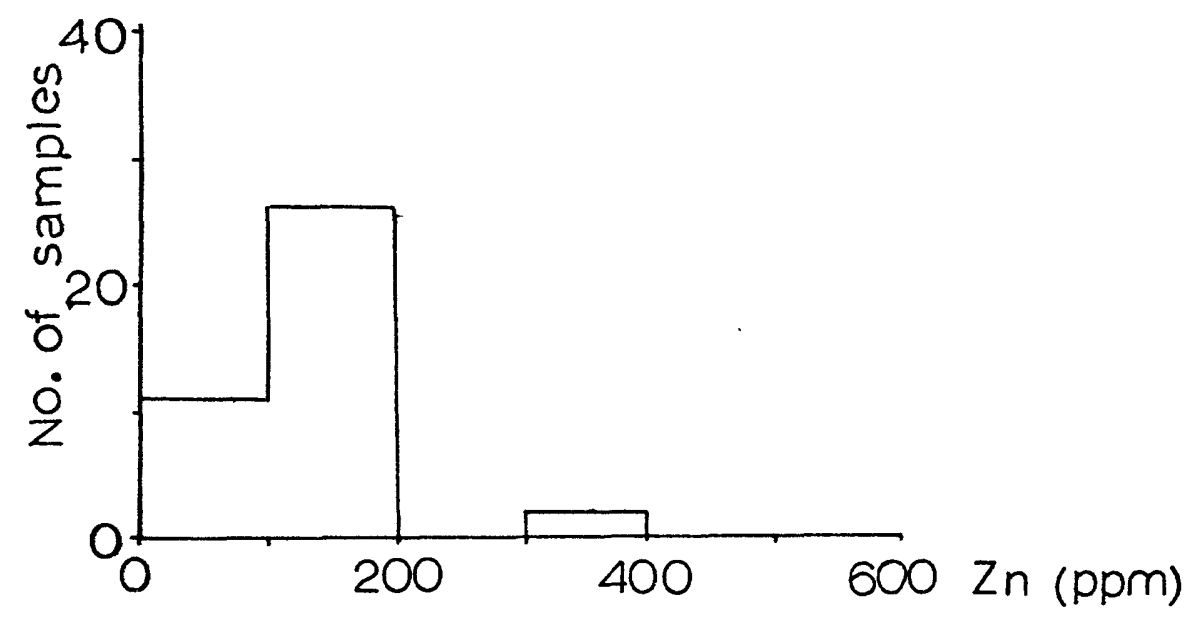

Frequency distribution of $\mathrm{Zn}$ in the greenstone and amphibolites. Range of values: 71-385 ppm. 
APPENDIX 2 (cont.)

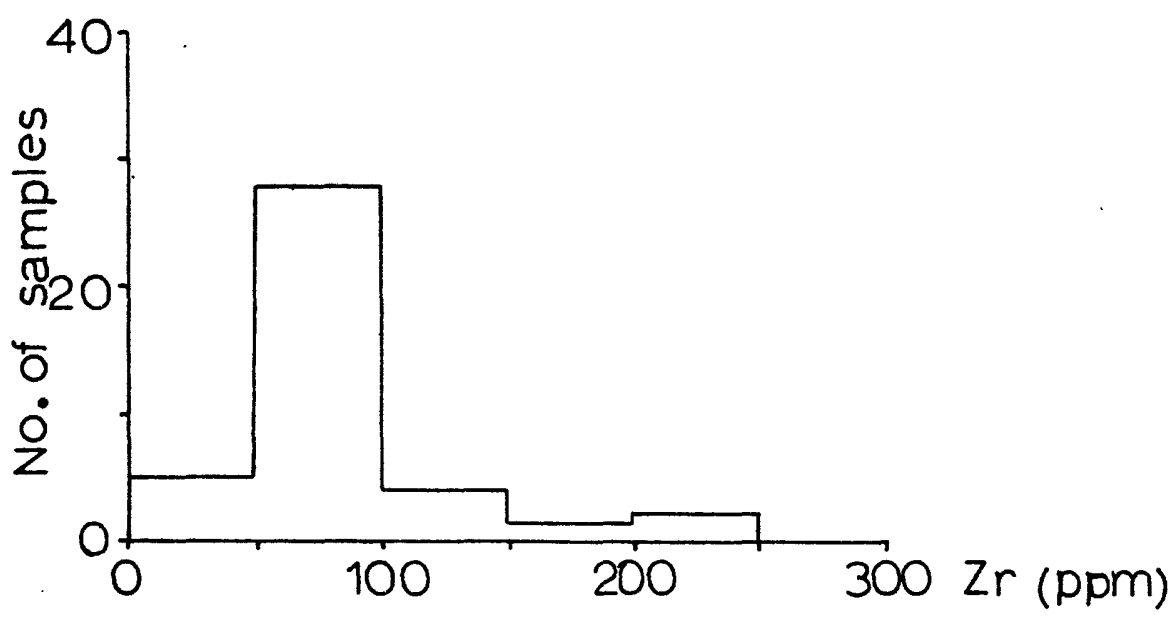

Frequency distribution of $\mathrm{Zr}$ in the greenstone and amphibolites. Range of values: 40-224 ppm. 